UNIVERSIDADE DE SÃO PAULO

FACULDADE DE FILOSOFIA, LETRAS E CIÊNCIAS HUMANAS

DEPARTAMENTO DE GEOGRAFIA

PROGRAMA DE PÓS-GRADUAÇÃO EM GEOGRAFIA HUMANA

MIGUEL MARQUES CROCHIK

GENTRIFICAÇÃO VERDE:

O URBANISMO SUSTENTÁVEL COMO INSTRUMENTO DA

REESTRUTURAÇÃo IMOBILIÁRIA DE PERUS - SÃO PAULO.

Versão Corrigida 
UNIVERSIDADE DE SÃO PAULO

FACULDADE DE FILOSOFIA, LETRAS E CIÊNCIAS HUMANAS

DEPARTAMENTO DE GEOGRAFIA

PROGRAMA DE PÓS-GRADUAÇÃO EM GEOGRAFIA HUMANA

MIGUEL MARQUES CROCHIK

\title{
GENTRIFICAÇÃO VERDE: \\ O URBANISMO SUSTENTÁVEL COMO INSTRUMENTO DA REESTRUTURAÇÃO IMOBILIÁRIA DE PERUS - SÃO PAULO.
}

\author{
Versão Corrigida
}

Dissertação de Mestrado apresentada ao Programa de Pós Graduação em Geografia Humana do Departamento de Geografia da Faculdade de Filosofia, Letras e Ciências Humanas da Universidade de São Paulo.

Orientadora Prof. ${ }^{\mathrm{a}}$ Dr. $^{\mathrm{a}}$ Amélia Luisa Damiani. 
Autorizo a reprodução e divulgação total ou parcial deste trabalho, por qualquer meio convencional ou eletrônico, para fins de estudo e pesquisa, desde que citada a fonte.

Catalogação na Publicação

Serviço de Biblioteca e Documentação

Faculdade de Filosofia, Letras e Ciências Humanas da Universidade de São Paulo

C937g GENTRIFICAÇÃO VERDE: O URBANISMO SUSTENTÁVEL COMO INSTRUMENTO DA REESTRUTURAÇÃO IMOBILIÁRIA DE PERUS - SÃO PAULO. / Miguel Marques Crochik ; orientadora Amélia Luisa Damiani. - São Paulo, 2018. $224 \mathrm{f}$.

Dissertação (Mestrado) - Faculdade de Filosofia, Letras e Ciências Humanas da Universidade de São Paulo. Departamento de Geografia. Área de concentração: Geografia Humana.

1. gentrificação verde. 2. reestruturação imobiliária. 3. urbanismo sustentável. 4. Perus, São Paulo, SP. 5. créditos de carbono. I. Damiani, Amélia Luisa, orient. II. Título. 


\section{ENTREGA DO EXEMPLAR CORRIGIDO DA DISSERTAÇÃO/TESE}

\section{Termo de Ciência e Concordância do (a) orientador (a)}

Nome do (a) aluno (a): _Miguel Marques Crochik

Data da defesa: _19_/_12_/_2018

Nome do Prof. (a) orientador (a): _Amélia Luisa Damiani

Nos termos da legislação vigente, declaro ESTAR CIENTE do conteúdo deste EXEMPLAR CORRIGIDO elaborado em atenção às sugestões dos membros da comissão Julgadora na sessão de defesa do trabalho, manifestando-me plenamente favorável ao seu encaminhamento e publicação no Portal Digital de Teses da USP.

São Paulo, $01 / 03 / 2019$

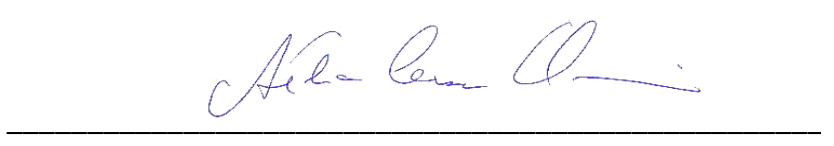

(Assinatura do (a) orientador (a) 


\section{FICHA DE APROVAÇÃO}

Autor: Miguel Marques Crochik

Título: Gentrificação verde: o urbanismo sustentável como instrumento da reestruturação imobiliária de Perus - São Saulo

Dissertação de mestrado apresentada ao Programa de Pós-Graduação em Geografia Humana da Faculdade de Filosofia, Letras e Ciências Humanas da Universidade de São Paulo, sob orientação da Prof ${ }^{a}$ Dra. Amélia Luisa Damiani, para a obtenção do título de Mestre na área de Geografia Humana.

\section{Banca Examinadora}

$\operatorname{Prof}(\mathbf{a}) . \operatorname{Dr}(\mathbf{a})$.

Instituição: Julgamento:

Assinatura:

$\operatorname{Prof(a).~} \operatorname{Dr}(a)$.

Instituição: Julgamento:

Assinatura:

$\operatorname{Prof(a).~} \operatorname{Dr}(a)$.

Instituição: Julgamento:

Assinatura: 


\section{AGRADECIMENTOS}

O processo de pesquisa foi longo e desafiador, mas a parte dos agradecimentos é uma das mais difíceis, por conta do receio enorme de esquecer o nome de alguém querido. Sem dúvida é uma injustiça, mas é inevitável, desde já me desculpo. Nesse tempo tive a sorte de cruzar ou conviver com muita gente generosa que me ajudou diretamente a fazer o trabalho. Flora, Amélia Luisa, Jandira, Luana, Ricardo, Adriana, Romilda, Andreia, Denis, Leandro, Beth, Elcio, Romilton, Carlos, Amélia, Pascoal, Dida, Simone, Soró, André Amano, Ramone, Rosa, Vivian, Dri, Marcela, Guiomar, Odette, Isabel, Carlão, Nuria Benach, colegas do grupo de estudos de Marx e dos situacionistas, Soninha, Iuri, Rafael, Clara, Cecilia, Camila, Lívia, Nathalee, Julio, Daniel Manzione, Nayara, Paula Puh, Richard, Fernanda, Juninho, Andrei, Haind, Theo, Feres, Delgado, Sergio, Gu, Isa, Felipe, Ligia, Léo, Laila, Clara, João, Lara, Cleide, MUITO OBRIGADO! Agradeço também a todxs queridxs e incríveis amigxs que tenho e que, indiretamente, me ajudaram muito pela sua existência e companheirismo. Essa pesquisa foi financiada pelo CNPq. 
Dedico este trabalho à memória de luta e resistência dos Queixadas. 


\section{RESUMO}

Essa dissertação aborda o processo de reestruturação imobiliária da região noroeste da metrópole de São Paulo, em particular o distrito de Perus, cujas transformações socioespaciais progrediram de um bairro operário para uma periferiadormitório e, então, potencialmente, para um local adequado à logística e à sustentabilidade. Este último movimento ocorre, sobretudo, através do impulso dado pela construção do Rodoanel que estimula a construção de novos produtos imobiliários, notadamente, centros logísticos e condomínios residenciais. Também atuam nessa transição projetos urbanísticos sustentáveis que estão previstos ou em implantação em Perus. A pesquisa analisa o conteúdo desses projetos e a sua origem, visto que foram financiados com dinheiro da venda de créditos de carbono negociados pela Prefeitura de São Paulo com empresas transnacionais. Nossa hipótese é que esses planos urbanísticos cumprem papel de "esverdear a fronteira urbana" e de promover uma espécie de "gentrificação verde", através da remoção forçada de famílias e do controle do tipo de uso do solo. Examinamos ainda a política pública de implantação de parques lineares, localizados em sua maioria na periferia da cidade de São Paulo, refletindo a respeito dos impactos desses projetos na vida da classe trabalhadora e na dinâmica do processo de urbanização, o que nos conduziu a observar uma relação entre o urbanismo sanitarista e o urbanismo sustentável.

Palavras-chave: gentrificação verde; reestruturação imobiliária; urbanismo sustentável; Perus, São Paulo, SP; créditos de carbono. 


\begin{abstract}
This dissertation examines the process of real estate development in the northwestern region of the São Paulo metropolis, in particular, the district of Perus, where a process of socio-spatial transformation has resulted in its character progressing from from being a working-class neighborhood to a dormitory-periphery suburb of São Paulo and, as such, an area potentially suitable for investments in logistics and sustainable living. This most recent changes have occurred mainly due to the impulse provided by the construction of the São Paulo ring road ("Rodoanel"), which has stimulated the construction of new real estate developments, notably, logistics centers and residential condominiums. Other factors that contributed to this transformation were the sustainable urban projects, planned or already under construction, in Perus itself. This research analyzes the content of these projects and their origin, since they were financed with funding from the sale of carbon credits by the São Paulo Municipal Administration to transnational companies. Our research hypothesis is that these urban plans effectively fulfill the role of "greening the urban frontier" and promote a kind of "green gentrification" which involves the forced removal of families and the control of land use. We also examined the public policy of implementing linear parks, which are mainly located in the outskirts of the Municipality of São Paulo. We reflected on the impacts of these projects on the life of the working class population and the dynamics of the urbanization process, leading us to observe that there is a relationship between sanitary urbanism and sustainable urbanism.
\end{abstract}

Key words: green gentrification; real estate development; sustainable urbanism; Perus, São Paulo, SP; carbon credits. 


\section{LISTA DE ABREVIATURAS E SIGLAS}

CBCPP Companhia Brasileira de Cimento Perus Portland S.A.

CDHU Companhia de Desenvolvimento Habitacional e Urbano

CEAGESP Companhia de Entrepostos e Armazéns Gerais de São Paulo

CEB Comunidade Eclesial de Base

CEU Centro Educacional Unificado

CEPAC Certificado de Potencial Adicional de Construção

CONFEMA Conselho do Fundo Especial do Meio Ambiente e Desenvolvimento Sustentável

COHAB Companhia Metropolitana de Habitação de São Paulo

DERSA Desenvolvimento Rodoviário S/A

E.E. $\quad$ Escola Estadual

EFSJ Estrada de Ferro Santos Jundiaí

FEMA Fundo Especial do Meio Ambiente e Desenvolvimento Sustentável

FII Fundo de Investimento Imobiliário

GEE Gases de Efeito Estufa

IPCC Painel Intergovernamental sobre Mudanças Climáticas

LPUOS Lei de Parcelamento, Uso e Ocupação do Solo

MDL Mecanismo de Desenvolvimento Limpo

NESP Novo Entreposto de São Paulo

ONU Organização das Nações Unidas

OUC Operação Urbana Consorciada

PL Projeto de Lei

PMSP Prefeitura Municipal de São Paulo

PRE Plano Regional Estratégico

RCE Redução Certificada de Emissões

UAM Unidade Ambiental de Moradia

ZEIS Zonas Especiais de Interesse Social 


\section{LISTA DE FIGURAS}

Figura 1 - Imagem de satélite da região de Perus, zona norte de São Paulo 26

Figura 2 - Imagens de satélite da área do Centro Logístico de Cajamar em 2008

Figura 3 - Imagens de satélite da área do Centro Logístico de Cajamar em 2018

Figura 4 - Imagem de satélite de área do bairro do Gato Preto (Cajamar), em 2008, 52 antes da remoção

Figura 5 - Imagem de satélite de área do bairro do Gato Preto (Cajamar), em 2017, 52 depois da remoção

Figura 6 - Placas com ofertas de terrenos e imóveis na entrada do Recanto do Humildes 59

Figura 7 - Diagrama de empresas e produtos relacionados à Termoelétrica Bandeirantes 70

Figura 8 - As três fases de implantação do Complexo do Bamburral 114

Figura 9 - Imagens projetadas de como seria o Conjunto Habitacional do Bamburral 126

Figura 10 - Principais propostas de expansão e reestruturação urbana do Plano de 132

Bairro de Perus

Figura 11 - Modelo de faixa que foi exposta no bairro para divulgar uma das 133 assembleias do Plano de Bairro de Perus

Figura 12 - Desenho feito pelo urbanista Candido Malta para o Plano de Bairro de 137 Perus

Figura 13 - Proposta do Plano de Bairro para reestruturação espacial do centro de Perus 145

Figura 14 - Proposta de novo Anel Rodoviário no entorno do distrito de Perus 147 


\section{LISTA DE MAPAS}

Mapa 1 - Microbacias hidrográficas do Rio Juqueri 19

Mapa 2 - A reestruturação imobiliária em processo na região noroeste da RMSP 57

Mapa 3 - Assentamentos precários e novos empreendimentos imobiliários em Perus e 62 adjacências

Mapa 4 - Casas inseridas no projeto Complexo do Bamburral 115

Mapa 5 - Projeto de casas removidas no Complexo do Bamburral 115

Mapa 6 - Proposta urbanística do Plano de Bairro de Perus as áreas próximas à fábrica 153

de cimento

Mapa 7 - A reestruturação imobiliária em processo no distrito de Perus 161

Mapa 8 - Parques lineares planejados e implantados no município de São Paulo (2014) 179

Mapa 9 - Distribuição territorial dos assentamentos ameaçados ou removidos conforme 185

motivo alegado

Mapa 10 - Distribuição territorial das ameaças de remoção e remoções devido a 186 implantação de área verde, no município São Paulo

\section{LISTA DE TABELAS}

Tabela 1 - População na Subprefeitura de Perus e em seus distritos 39

Tabela 2 - Crescimento populacional na Subprefeitura de Perus e em seus distritos 39

Tabela 3 - As três subprefeituras que tiveram maior crescimento populacional em São 39

Paulo nas décadas de 1991/2000 e 2000/2010

Tabela 4 - Arrecadação da PMSP com os leilões dos créditos de carbono 69

Tabela 5 - Local de destino das 294 famílias logo após a remoção do Complexo do 120 Bamburral 


\section{Sumário}

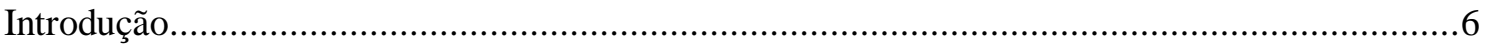

1. O BAIRRO DE PERUS E A REESTRUTURAÇÃO IMOBILIÁRIA...................................11

1.1. Reestruturação imobiliária e situação geográfica.......................................................... 11

1.2. A produção da situação geográfica de Perus................................................................... 17

1.3. A formação da vida de bairro a partir de lutas sindicais e por condições de vida urbana 30

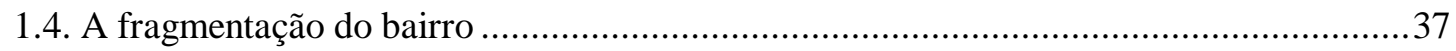

1.5. A reestruturação imobiliária na região noroeste da RMSP .............................................43

1.6. O papel dos créditos de carbono na reestruturação imobiliária.......................................63

1.7. O material e o simbólico na reestruturação imobiliária ....................................................71

2. NOTAS SOBRE O AMBIENTALISMO E OS NOVOS NEGÓCIOS “VERDES”...............75

2.1. Apontamentos sobre o conceito de natureza na urbanização da sociedade ......................75

2.2. A decomposição do ambientalismo: da contestação à ideologia e ao mercado .................81

2.3. Os novos negócios "verdes": o processo de abstração do ar .............................................89

2.4. O "desenvolvimento sustentável” nos bastidores do Banco Mundial ..............................97

3. ANÁLISE DOS PROJETOS DE URBANISMO "SUSTENTÁVEL” DE PERUS ................99

3.1. A transformação dos créditos de carbono em urbanismo "sustentável" ..........................99

3.2. A "cidade sustentável" e o urbanismo enquanto força produtiva................................... 102

3.3. O Parque Linear do Ribeirão Perus ............................................................................. 109

3.4 O “Complexo do Bamburral”: análise de uma remoção "sustentável” ...........................112

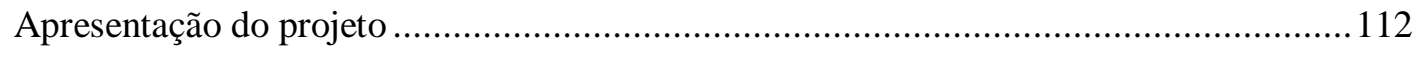

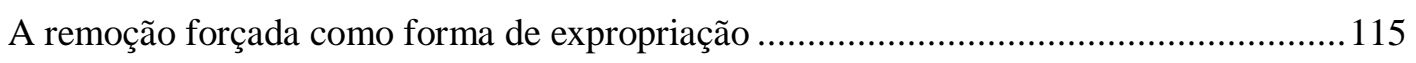

O ambientalismo espetacular: análise dos argumentos técnicos ..................................... 123

3.5. Apontamentos sobre o Plano de Bairro do Distrito de Perus .......................................... 126

Aspectos gerais de um projeto "sustentável” de reestruturação imobiliária ......................127

O processo "participativo" de elaboração do Plano de Bairro de Perus .............................131

O "sistema de áreas verdes": remoções e gentrificação .................................................... 136

Reprodução e expansão urbana: reestruturação do centro, novo anel viário e a "vocação"

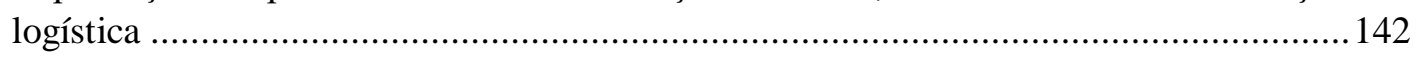

Os interesses em torno da Fábrica de Cimento e da memória do bairro ...........................151

4. DA CIDADE SAUDÁVEL À CIDADE "SUSTENTÁVEL”: HIGIENISMO,

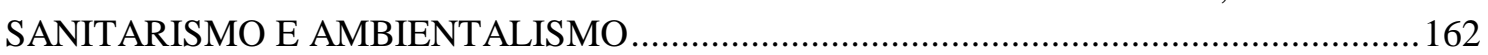

4.1. O Higienismo: domesticação do espaço e da classe trabalhadora................................... 162

4.2. Considerações sobre o higienismo na cidade de São Paulo ........................................... 171

4.3. As moradias em fundo de vale e os parques lineares como política pública .................. 177

4.4. Urbanismo sanitarista, urbanismo "sustentável” e expropriação ......................................192

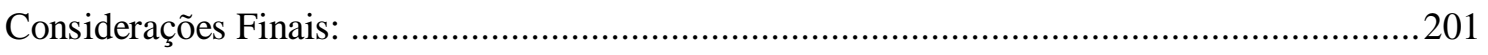


Referências bibliográficas:

Anexo 1 - Descrição dos gastos dos recursos dos créditos de carbono da PMSP entre 2008 e 2011 


\section{Introdução}

A violência do processo econômico capitalista se reitera ao longo da história e sua expressão enquanto urbanização revela o acirramento de sua crise e, em consequência, da dominação de classe. A consolidação da produção do espaço (LEFEBVRE, 2006; 2008a) como uma das principais alternativas à crise de reprodução do capital intensifica o ritmo do processo de expropriação (proletarização). Nas grandes cidades brasileiras, cuja estruturação espacial tem, como elemento essencial, a contínua espoliação urbana (KOWARICK, 1980), essa circunstância gera uma reprodução do espaço urbano malthusiana (DAMIANI, 2010), isto é, que resulta no agravamento da penúria da classe trabalhadora. A cidade tornada negócio tem uma inclinação a se converter em "cenário" (GONÇALVES G.R., 2016), ou seja, espaço decorativo para o qual, muitas vezes, as frações mais pobres da classe trabalhadora são "dispensáveis".

Tendo em vista esse contexto, a presente dissertação tratou de investigar as formas de aparecimento desse processo crítico de urbanização (DAMIANI, 2008; 2009; 2010), a fim de desmistificar alguns mecanismos que o sustentam. Especificamente, buscamos estabelecer uma reflexão acerca das relações entre o processo de expansão / reestruturação espacial da metrópole de São Paulo e a ascensão do chamado planejamento urbano "sustentável”. A estrutura fundiária e as recentes transformações na região de Perus, bairro periférico da zona noroeste, trazem importantes elementos para a compreensão dessa relação.

Esse bairro guardava, até recentemente, características de um subúrbio operário, cuja vida cotidiana estava fortemente vinculada às determinações da fábrica de cimento (então em funcionamento) e da militância sindical e cristã. A partir do final dos anos 1980 essa região tornou-se, definitivamente, frente de expansão do padrão periférico de urbanização (BONDUKI, 2001), com altas taxas de crescimento populacional, assumindo uma feição mais típica de periferia metropolitana, como "bairro dormitório", apesar da manutenção de muitos de muitos terrenos rurais no entorno do núcleo de Perus. Em 2002, a inauguração do Rodoanel - trecho oeste e a proximidade da inauguração do trecho norte, ambos em Perus - trouxe consigo um processo - real e potencial - de reestruturação imobiliária para a região noroeste. Esse movimento compreende um componente de expansão urbana: espaço rural sendo urbanizado; grandes propriedades de terras sendo fragmentadas e negociadas; terrenos 
em especulação etc.. E também de reprodução do espaço, através: da destruição de antigas construções; de remoções forçadas; de um incipiente processo de verticalização.

Buscamos investigar como esse recente movimento explicita conteúdos da reestruturação imobiliária da metrópole, envolvendo relações contraditórias entre proprietários de terra, mercado financeiro-imobiliário, Estado e a população local. Classificada como "última fronteira urbana" - por conta da disponibilidade de terras não urbanizadas - a região noroeste vem sendo alvo de uma série de projetos de negócios imobiliários, sobretudo relacionados a centros logísticos e condomínios residenciais que, junto com novas estruturas viárias, são os impulsos para a valorização dessas áreas, historicamente, periféricas.

Observamos, a partir desse fragmento urbano, como o movimento de passagem de uma produção fordista para uma produção flexível vem transformando o espaço da metrópole (BOTELHO, 2006). Trata-se de um amplo processo de reestruturação espacial que assume diversas faces e complexifica o entendimento sobre o conflito de classes envolvido na produção do urbano.

Esses instrumentos [operação urbana e outorga onerosa do direito de
construir], associados a medidas legais e macroeconômicas, como as normas
legais de securitização de dívidas imobiliárias, a facilitação legal de entrada e
saída de investimentos estrangeiros, o aumento da taxa de juros, a abertura de
capital das principais construtoras e incorporadoras na bolsa de valores, as
obras relativas à Copa do Mundo, têm impulsionado profundas modificações
na metrópole, com direcionamento de investimentos públicos e privados, em
projetos de reestruturação e requalificação urbana, em áreas de valorização
mais centrais, mas também avançando para porções da periferia, num
processo de absorção desses espaços a uma lógica de valorização que se
generaliza e que impede os mais pobres de conseguir pagar o aluguel, tendo
que se direcionar para áreas cada vez mais distantes, reproduzindo o padrão
periférico de expansão urbana. (ALVAREZ, 2014, p.292)

Para essa transição, "velhos usos" do espaço têm de ser substituídos, de modo que tornam-se necessários discursos que legitimem, frente à população local, a adequação espacial às novas modalidades de reprodução do capital no espaço urbano (BENACH, 2004).

O ambientalismo parece-nos ser elemento chave para compreensão da passagem de um bairro de "confinamento" da classe trabalhadora para uma possível nova centralidade. No distrito de Perus, alguns projetos urbanísticos sustentáveis estão previstos e, outros, estão em processo de implantação. Sendo assim, a reestruturação imobiliária apresenta-se aí através de um binômio contraditório: Rodoanel-preservação ambiental, sendo o primeiro termo estimulador para expansão do espaço construído enquanto o segundo propõe justamente o contrário. 
Ao longo do texto trataremos dessa questão a partir da hipótese de que tais projetos urbanísticos são um meio de "esverdear a fronteira urbana" (SAFRANSKY, 2014) e promover uma espécie de "gentrificação verde", através da remoção de centenas de famílias e do controle do tipo de uso do solo. Apesar de se proclamar como “desenvolvimento sustentável” o que se reproduz é o "desenvolvimento desigual" (SMITH, 1988), condição de existência do capitalismo.

Observa-se um processo de expropriação através da produção de “infraestruturas verdes" cuja disseminação nas políticas do espaço nos levou a investigar um possível fio de continuidade entre as filosofias higienista e ambientalista (SEABRA, 2013), especialmente no que se refere à prática do urbanismo que se desdobra desses dois conjuntos de ideias.

Outra peculiaridade que dá sentido à pesquisa é que parte desse conjunto de projetos de urbanismo sustentável foi financiado graças à produção de bioenergia no Aterro Sanitário Bandeirantes, localizado em Perus e, que tem, por consequência a geração de créditos de carbono, ou seja, papéis financeiros que podem ser negociados no mercado internacional. A Prefeitura Municipal de São Paulo (PMSP), proprietária do terreno do aterro, teve direito a vender esses créditos em leilões na Bolsa de Valores de São Paulo, em que arrecadou cerca R $\$ 75$ milhões, sendo a maior parte revertida em projetos sustentáveis para a região noroeste. Observa-se assim a natureza transformada em estratégia de acumulação (SMITH, 2006) através de distintos negócios, inclusive envolvendo a produção do espaço.

Procuramos, a partir do método dialético, confrontar constantemente teoria e prática, e expor aqui a análise dos temas que elegemos como os mais importantes para colaborar com uma compreensão das contradições do atual movimento de produção do espaço, estudado a partir da urbanização da região de Perus.

Nos últimos dez anos o avanço de uma reestruturação imobiliária oscilou associado a impulsos do mercado financeiro, quase sempre amparados pelo Estado. $\mathrm{Na}$ virada da década passada para a atual, uma série de investimentos públicos e privados foram especulados no distrito de Perus. Poucos se realizaram, alguns estão em implantação (por vezes em ritmo moroso) e, muitos, ainda não saíram do papel. Sem dúvida, a injeção de dinheiro no espaço e, em projetos para o espaço - possibilitada pela negociação de créditos de carbono -, foi fator relevante nesse processo. A aposta de que a construção de moradias para a então "ascendente classe média" poderia dar vazão aos capitais imobiliários também moveu parte da onda de projetos para a região, sendo o 
subsídio do programa Minha Casa Minha Vida (MCMV) um elemento importante para esse movimento. Contudo, os produtos imobiliários associados à logística ${ }^{1}$ vêm sendo, nos últimos vinte anos, os principais vetores para a reestruturação imobiliária da região.

O ponto de partida da pesquisa foi o bairro de Perus, local conheço e desenvolvo pesquisas há sete anos. A convivência com seus habitantes e os depoimentos colhidos ao longo desse período foram materiais básicos para o desenvolvimento dessa pesquisa $^{2}$. A análise também se baseou em documentos oficiais do Estado, como planos urbanísticos, leis, projetos de leis, atas de reuniões; além de documentos de empresas privadas envolvidas com negócios na região, notícias e revisão bibliográfica.

A complexidade do real nos levou a abranger diversos temas dentro da mesma pesquisa a fim de buscar uma análise que fizesse sentido diante das múltiplas determinações da reprodução da metrópole.

Os textos que compõem essa dissertação estão divididos em quatro capítulos. $\mathrm{O}$ primeiro tem por objetivo traçar o percurso sobre o processo de formação do bairro de Perus e da "situação geográfica" (GEORGE, 1983) da região noroeste. Através da análise das transformações socioespaciais ao longo do tempo buscamos problematizar a questão da reestruturação imobiliária na metrópole atualmente. Para tanto são analisadas algumas ações dos proprietários fundiários e dos capitais financeiro-imobiliários na região. Ainda nesse capítulo descrevemos o processo de produção e venda de créditos de carbono e, posteriormente, iniciamos uma reflexão sobre a importância do caráter simbólico para a reprodução do espaço.

$\mathrm{Na}$ segunda parte, analisamos a "imagem-conceito de natureza" (LEFEBVRE, 1969) na sociedade capitalista para, então, abordar o surgimento de novas mercadorias relacionadas à chamada "economia verde". Para entendermos a formação desse novo ramo de negócios, abordamos, de maneira resumida, o histórico do movimento ambientalista, passando pelo o ocultamento do seu caráter contestatório e pela constituição do predomínio de uma concepção ambientalista reprodutora das relações sociais de produção. Além disso, para nos aprofundarmos na gênese da mercadoria crédito de carbono, analisamos o processo de precificação e comercialização de moléculas da atmosfera.

\footnotetext{
${ }^{1}$ Isto é, entrepostos comerciais destinados a gerir a armazenagem, transporte e distribuição dos produtos, tendo como finalidade a redução dos custos de circulação das mercadorias.

${ }^{2}$ Alguns entrevistados solicitaram que seus verdadeiros nomes não fossem divulgados, por isso, todas as pessoas que deram depoimentos serão apresentadas com nomes fictícios.
} 
No capítulo três estabelecemos uma ponte entre dois ramos dos "novos negócios verdes". Observamos como os créditos de carbono transformaram-se em projetos de urbanismo sustentável, tendo por objetivo analisar o que está sendo proposto por essa nova modalidade de planejamento, quais suas estratégias e como elas atingem a vida das pessoas. Após uma introdução sobre o papel do urbanismo na reprodução da cidade como negócio, nos debruçamos sobre três projetos financiados pelos créditos de carbono: o Parque Linear do Ribeirão Perus; o conjunto habitacional sustentável "Complexo do Bamburral"; e o Plano de Bairro do Distrito de Perus.

A análise desses projetos nos levou a identificação do "parque linear" como principal instrumento de uma política urbana "sustentável”, não só em Perus, mas no município como um todo. No quarto capítulo, nos dedicamos a examinar essa forma de intervenção sistemática nos fundos de vale de zonas periféricas, muitas vezes ocupadas por favelas, considerando os impactos desses projetos na vida da classe trabalhadora e, também, na dinâmica do processo de urbanização. Assim, esboçamos alguns apontamentos sobre semelhanças e continuidades entre o urbanismo sustentável e o que foi o urbanismo sanitarista, fato que nos requereu realizar uma aproximação em relação à gênese do higienismo.

\footnotetext{
3 Trata-se de uma concepção urbanística de equipamentos que têm como proposta recuperar os ecossistemas ao longo da rede hídrica de áreas urbanas, buscando estabelecer áreas de vegetação conectadas e, também, visando controlar as enchentes. Além disso, objetiva-se transformar esses espaços em áreas de lazer de uso "sustentável". É importante ressaltar que a ideia estatista de "linearidade" tem pouco sentido, visto que os parques devem acompanhar rios e riachos que não são retos, são curvos e obedecem às condições do sítio.
} 


\section{O BAIRRO DE PERUS E A REESTRUTURACÃO IMOBILIÁRIA}

\subsection{Reestruturação imobiliária e situação geográfica}

O objetivo deste capítulo é contextualizar o leitor acerca do tema da dissertação. Essa aproximação necessária se dará em dois aspectos. O primeiro, de ordem lógicoteórica, em torno do processo de reestruturação imobiliária em curso na metrópole de São Paulo. O segundo, de ordem histórica, trata de buscar as continuidades e descontinuidades no processo de urbanização de Perus, a fim de familiarizar o leitor com o que há de específico em sua formação socioespacial.

As transformações na organização e paisagem do espaço metropolitano levamnos a buscar uma fundamentação teórica que permita uma melhor compreensão dos fatos. Historicamente, a crise de reprodução do capital, deflagrada a partir dos anos 1970, é um ponto de ruptura em algumas práticas capitalistas, em específico na forma como produz o espaço. É necessária uma aproximação política e econômica para uma compreensão do que vem se desdobrando desde então ${ }^{4}$. Alvarez (2014) resume algumas características gerais do capitalismo pós-crise dos anos 1970:

Nas últimas décadas, a queda tendencial da taxa de lucro novamente colocou
em xeque as possibilidades da reprodução ampliada, intensificando os
momentos de desvalorização e destruição de ativos, nos quais a expropriação
e a exploração se intensificam, com consequências sociais profundas. Nesse
contexto cresceu em importância e autonomização o capital fictício,
desenvolveu-se a reestruturação produtiva e o fomento das políticas
neoliberais em que se destacam as privatizaçães, a desregulamentação, o
corte de verbas às políticas e direitos sociais, o aumento da exploração e da
expropriação (Ibid., p. 281).

A ideia de "reestruturação produtiva" da sociedade capitalista nos parece crucial para que possamos entender as transformações histórico-geográficas da metrópole. A mudança das estratégias de acumulação do capital, em transição do fordismo à produção flexível, gera consequências na produção do espaço (BOTELHO, 2000). A nosso ver, as características mais marcantes são a reorganização técnica e espacial das forças produtivas, concomitante a um rearranjo nas relações sociais de produção, cujo sentido maior é o aumento da exploração da força de trabalho. Segundo Alvarez (2014, p. 283), a reestruturação produtiva pode ser compreendida "como as transformações relacionadas à tecnologia e organização da produção e circulação, mas, sobretudo a

\footnotetext{
${ }^{4}$ Não é nosso objetivo aqui nos aprofundarmos sobre a natureza econômica da crise capitalista. No entanto, em alguns momentos daremos mais destaque a algumas especificidades importantes para $\mathrm{o}$ argumento desenvolvido, tendo em vista o materialismo histórico dialético.
} 
reorganização das relações de trabalho e emprego, cujo sentido majoritário é o da precarização e maior exploração".

Em resumo, essa reestruturação é uma tentativa do capital para aumentar a produtividade do trabalho e, simultaneamente, diminuir a remuneração média dos trabalhadores. Evidentemente, a readequação capitalista tem um componente de reorganização espacial da produção, o que afeta o espaço urbano e o agrário. Inclusive, é nesse período, década de 1970, que Lefebvre formula a teoria da "produção do espaço" (2006; 2008a) como meio de enfrentamento da crise capitalista. Portanto, a reestruturação produtiva se desdobra em uma reestruturação espacial. É inegável que esse processo todo não se dá de forma linear, mas, sim, é repleto de sinuosidades.

No espaço metropolitano, é possível identificar essa passagem por meio da "reestruturação imobiliária" (PEREIRA, 2006) que aparece como quebra nos modelos de compreensão da cidade consagrados na literatura: "Diante da complexidade da questão urbana e do avanço dos negócios da urbanização, há uma argumentação substantiva considerando insuficiente o modelo centro-periferia como modo de explicação suficiente da cidade de São Paulo" (DAMIANI, 2008, p. 244). A indústria imobiliária cresce, oferece novos produtos ao mercado e se reorganiza do ponto de vista financeiro e produtivo. A produção do espaço urbano se afirma como negócio (CARLOS, 2004), e a propriedade da terra lastro para a reprodução de capital fictício ${ }^{5}$.

Projetos de expansão e reestruturação espacial se espalham nas cidades, redefinindo os usos dos espaços em busca de criar novas centralidades. Esse processo se apresenta sob distintas formas espaciais e em fragmentos diversos da metrópole:

\begin{abstract}
Nas últimas décadas a desativação de áreas industriais (especialmente nos eixos mais antigos, relacionados aos rios Tamanduateí, Tietê e Pinheiros), a consolidação de um eixo de valorização imobiliária residencial, com expansão para novas áreas e incorporação de diferentes faixas de rendimentos, a constituição de um circuito de centros comerciais com o padrão de exclusividade e segregação social, os projetos de renovação da área central, a abertura e construção de vias, especialmente o rodoanel, os programas chamados de recuperação ambiental, como a criação de parques e de recuperação de mananciais, as obras para a Copa de 2014, as remoções de
\end{abstract}

\footnotetext{
5 "A propriedade da terra, no capitalismo, não é em si capital, mas pelo monopólio, através da forma jurídica da propriedade, possibilita a capitalização de parte da mais valia geral como renda, o que confere aos seus detentores não apenas a possibilidade do uso, mas também a de absorver parte da riqueza social através da troca, liberando o capital imobilizado para entrar no circuito geral de valorização do capital. Ainda por permitir ganhos atuais e futuros derivados de seu monopólio, a propriedade é patrimônio capaz de ser garantia de empréstimos e crédito e, portanto, se insere no empenho do trabalho futuro" (ALVAREZ, 2014, p. 281). Feita a partir de HARVEY (1990), essa constatação formula que a propriedade da terra, sob o modo de produção capitalista, funciona como um "capital fictício", podendo gerar crescimento do capital sem, necessariamente, passar pela produção real imediata. O monopólio da terra pode exprimir, atualmente, uma volatilidade capaz de gerar excepcional circulação de dinheiro através de uma projeção futura da possibilidade de realização de valor, que pode não vir a se confirmar.
} 
favelas permitem dizer que a metrópole de São Paulo vive uma expressiva transformação intraurbana (ALVAREZ, 2014, p. 273).

Durante muito tempo, a estruturação da malha urbana da metrópole foi explicada teoricamente através do crescimento baseado na industrialização (de caráter dependente), nas linhas ferroviárias e na especulação com a terra. Além disso, a “espoliação urbana” (KOVARICK, 1980) definiu o chamado "padrão periférico" de urbanização (BONDUKI, 2001). No entanto, essa leitura é insuficiente para compreender tanto a deterioração e transformação das áreas industriais quanto o surgimento de novas centralidades em áreas historicamente periféricas, e muito menos serve para explicar os projetos de recuperação ambiental nas periferias ou de "revitalização" do centro. A reestruturação imobiliária aparece aos olhos do sujeito no cotidiano através de fragmentos "isolados" do urbano. É possível observar que ela segue alguns padrões: redefinição dos usos dos espaços através da destruição e reconstrução destes, bem como da expansão urbana para novas áreas, através de novas formas espaciais.

A unidade interpretativa possível para esse fenômeno passa pela compreensão de que a reprodução do capital está associada à reprodução do espaço, orientada pela lógica do capital financeiro. Alguns aspectos dessa ideia serão desdobrados nesse capítulo, mas um embasamento teórico maior será realizado no capítulo três.

Do ponto de vista da análise, há uma relativa dificuldade em articular essa ideia da reprodução do espaço (atrelada ao capital financeiro) com sua expressão local nos distintos fragmentos da metrópole. Como decifrar essa reestruturação imobiliária em sua textura fina? Como relacionar as transformações urbanas locais com o giro de capital financeiro imobiliário? Como elas resolvem ou adiam sua crise? Como articular as expressões locais de reprodução do espaço, com uma estratégia de reestruturação imobiliária que é global? Esses são questionamentos importantes, mas de difícil resposta, porque teoria e prática não coincidem, há nuances e necessidade de reinterpretação contínua.

Para esta dissertação, o conceito de "situação geográfica" (GEORGE, 1983) parece-nos uma importante ferramenta na busca de uma aproximação interpretativa. A análise da relação de uma cidade com seu meio natural é, para a ciência geográfica, definida, historicamente, a partir de duas escalas: a regional, chamada de situação ou posição, e a local, chamada de sítio.

O conceito de sítio pode ser definido como "o quadro topográfico no qual se enraizou a cidade, pelo menos em suas origens" (GEORGE, 1983, p. 37). Já a ideia de 
situação geográfica, refere-se à posição de uma cidade em relação ao espaço do entorno, isto é, refere-se a como as características específicas desse espaço podem se relacionar com seus arredores e, consequentemente, com o espaço social como um todo. Em sua concepção inicial, a situação era observada como sendo decisivamente condicionada pelas condições naturais. Por exemplo, uma cidade localizada no centro de uma bacia hidrográfica tem sua situação regional caracterizada por certas facilidades de circulação. Entretanto, diante do intenso desenvolvimento das forças produtivas observou-se que a influência posicional se daria, e se transformaria, segundo as técnicas do momento ${ }^{6}$. A situação geográfica se torna, portanto, "uma noção de valor relativo, expressa em função dos fatores circunstanciais de urbanização e desenvolvimento urbano" (Ibid.: 36-37, ênfase do autor). Isto é, a determinada posição de uma cidade no espaço é circunstancial, pois é condicionada pelas transformações da organização territorial.

A situação de uma cidade também está vinculada a fatores de produção, como, por exemplo, uma cidade posicionada próxima a uma montanha constituída por minerais valiosos. No entanto, as situações geográficas são comumente definidas pela localização em relação aos meios de circulação e troca de mercadorias. Uma posição estratégica em relação, por exemplo, aos meios de transporte (rios, ferrovias, estradas etc.) é decisiva para o processo de urbanização. Nesse sentido, as inovações tecnológicas têm papel central:

Após a revolução dos transportes, houve, em toda parte, uma reavaliação das diferentes vias naturais de circulação; consequentemente estabeleceu-se uma nova hierarquia de posições e sítios, ocasionando o declínio de certas cidades favorecidas pelas vias de circulação do passado e desativadas pelos grandes eixos modernos, por causa da concentração das correntes de circulação e da evolução das técnicas de transporte (GEORGE, 1983, p. 38).

Observa-se, na realidade, um constante processo de expansão dos meios de transporte, assim como algumas mudanças nos modais e tecnologias. Em contraposição a momentos passados, quando havia impressão de estabilidade da obra humana no espaço, é notável uma contínua mutabilidade das situações geográficas ${ }^{7}$. Ou seja, o espaço está em transformação conforme as mudanças técnicas e de organização da

\footnotetext{
6 "Inicia-se considerando as condicionantes naturais, que sugerem a repartição de tipos de cidades: posição em encruzilhada, em comunicações por vales, interflúvios de planalto...; posição em linha e zona de contato, entre a floresta e as clareiras...; cidades marítimas; cidades ribeirinhas...; etc.; logo, aparece o reconhecimento, que, sob esses impulsos naturais, a posição da cidade recebe os meios de comunicação sempre renovados e acrescentados" (DAMIANI, 2008, p. 175).

7 "Em tais condições, a geografia só pode ser uma geografia do movimento" (GEORGE, 1983, p. 221 apud DAMIANI, 2010, p. 46; ênfase do autor).
} 
produção. Resumidamente, a situação geográfica tende a se modificar de acordo com a passagem do tempo.

$\mathrm{Na}$ atual reestruturação produtiva, a terceira revolução industrial e o toyotismo causam modificações na organização territorial, pois enfatizam as possibilidades de ganhos logísticos na circulação de mercadorias, de modo que a reestruturação espacial tem relação direta com a redefinição das situações geográficas.

Nesse sentido, podemos afirmar que há um processo de redefinição da situação geográfica da metrópole de São Paulo como um todo em relação ao espaço regional (latu sensu). Mais do que isso: o fenômeno metropolitano alcançou tal magnitude que é também possível identificar quais fragmentos específicos da cidade passam a se relacionar com o espaço intraurbano e regional de forma específica e renovada. Isto é, há situações geográficas específicas para diferentes localizações do espaço metropolitano.

Nesse processo de redefinição imobiliária é inegável que o Estado cumpre um papel central, normalmente dando o "pontapé inicial" das mudanças na posição relativa de um bairro, através de ações como operações urbanas consorciadas, por exemplo, ou por intermédio da construção de uma gigantesca e nova estrutura de circulação, como o Rodoanel $^{8}$. Essa estrutura de circulação é decisiva para a compreensão da reestruturação imobiliária da metrópole como um todo e, especificamente para esta dissertação, da sua região noroeste. Essa estrutura redefine e expande a escala espacial dos negócios do setor imobiliário9 .

Devido à importância da reprodução do espaço para o capital, somos obrigados a refletir sobre o porquê de essa cadeia produtiva ter taxas de rendimento atraentes aos capitais. Partimos da hipótese de que as constantes mudanças nas situações geográficas possam ser aproveitadas como meios de obtenção de lucros extraordinários, oriundos da captação de rendas fundiárias (MARX, 2017). Para Damiani (2010) há uma relação

\footnotetext{
${ }^{8}$ O Rodoanel Mário Covas é um anel rodoviário metropolitano de aproximadamente 176,5 quilômetros de extensão que cruza as principais rodovias de acesso metropolitano: Bandeirantes, Anhanguera, Castelo Branco, Raposo Tavares, Régis Bittencourt, Imigrantes, Anchieta, Ayrton Senna, Dutra e Fernão Dias. O anel é divido em quatro trechos, sendo que já estão concluídos os trechos Leste, Oeste e Sul. O Trecho Norte está em fase de conclusão, previsto para ser entregue em 2019. As obras se iniciaram em 1998, no Trecho Oeste. A produção desse megaprojeto é controlada pelo Estado de São Paulo e pelo governo federal. O Rodoanel atravessa 16 municípios da Região Metropolitana de São Paulo (RMSP), além da capital: Santana de Parnaíba, Barueri, Carapicuíba, Osasco, Cotia, Embu das Artes, Itapecerica da Serra, São Bernardo do Campo, Santo André, Mauá, Ribeirão Pires, Poá, Suzano, Itaquaquecetuba, Arujá e Guarulhos.

${ }^{9}$ Ao longo dessa dissertação, quando mencionarmos o "setor imobiliário", em verdade, estaremos nos referindo a todos segmentos concernentes a essa cadeia produtiva, incluindo a incorporação fundiária, a construção civil, a comercialização imobiliária, entre outros negócios associados.
} 
direta entre o conceito de situação geográfica e o de renda fundiária ${ }^{10}$; a redefinição de uma situação geográfica pode criar um momento de especificidade de uma localidade urbana em relação às outras, de modo que se abre uma possibilidade de investimento com rentabilidade alta, se comparada a outros tipos de aplicações de capital, por conta de uma renda fundiária (ou situação geográfica) excepcional.

Damiani (2008) afirma que a busca por uma renda da terra excepcional seria uma forma do capital buscar compensar a queda tendencial da taxa de lucro ${ }^{11}$. Partindo de Marx, a autora chega a essa formulação: "Podemos recorrer a Marx e com ele à ideia de extração de lucros excepcionais, advindos das diferenças de situação. A busca de lucros excepcionais motiva Marx a refletir sobre a tendência, no capitalismo, de taxa de lucros decrescente" (DAMIANI, 2010, p. 45).

Assim sendo, o aspecto concorrencial entre os capitais se torna combustível para a redefinição de situações geográficas. Todos os espaços urbanos estão sujeitos à diferenciação posicional, devido à busca por taxas de lucros específicas que os capitais visam na produção do espaço, o que torna os lugares constantemente passíveis de valorização e desvalorização imobiliária: “a produção das configurações espaciais podese tratar como um 'momento' ativo dentro da dinâmica temporal global da acumulação e reprodução social" (HARVEY, 1990, p. 377). Na lógica da concorrência, a diferenciação espacial se dá pela busca do lucro excepcional que uma posição específica pode gerar. Uma das decorrências desse fenômeno é a homogeneização espacial, isto porque, tendo observado as rendas extras captadas pela concorrência, muitos capitalistas buscam se aproveitar também da nova situação geográfica. No entanto, a lógica dita que - uma vez generalizada essa taxa de lucro - ela se torna menos excepcional. Além disso, simultaneamente, outros espaços são redefinidos e também podem gerar ganhos excepcionais, tornando o espaço anterior obsoleto do ponto de vista de extração de renda fundiária.

A mesma excepcionalidade é própria das diferenças de situação e, por isso, elas não são estáveis. A corrida, movida nesta procura, leva à neutralização

\footnotetext{
10 “(...) a renda fundiária é uma parcela do excedente global produzido pela classe trabalhadora e que é apropriado pela classe dos proprietários fundiários, devido ao monopólio que exercem sobre a propriedade da terra" (BOTELHO, 2008, p. 26).

${ }^{11}$ Segundo Lefebvre (2008a), o investimento na produção do espaço se torna uma das contra tendências à queda da taxa de lucro. A busca dos capitais pelo setor imobiliário, que ocorre diante da dificuldade de realização da sua reprodução ampliada, justifica-se porque esse segmento pode oferecer algumas alternativas específicas contra a tendência à queda das taxas de lucro. Sendo essas alternativas, nomeadamente, três: 1- a menor composição orgânica da construção civil, que possibilita a maior formação de mais-valia; 2- a possibilidade de obter ganhos através da especulação imobiliária; 3- a possibilidade de somar aos lucros da produção, o sobre lucro oriundo da renda fundiária.
} 
das diferenças, quando a situação excepcional convenciona-se como novo patamar necessário, quando ela se generaliza.

E assim novas possibilidades, e outras posições, são produzidas, sempre com a finalidade de lucros extraordinários. O importante é compreender o movimento nessa busca e a produção, sempre renovada, de situações (DAMIANI, 2010, p. 45).

Essa busca renovada de novas situações tem relação direta com o processo de reestruturação imobiliária, que tem sido ativo na mobilização de terras urbanas para que essas possam entrar na dinâmica de valorização da indústria imobiliária, o que acarreta na intensificação da circulação de capital financeiro e fictício: "a necessidade de mobilizar a propriedade privada, como lastro do processo de financeirização, tem transformado a metrópole paulista num verdadeiro canteiro de obras, não apenas nas áreas mais centrais e valorizadas, mas também em parcelas da periferia" (ALVAREZ, 2014, p. 289). Para a autora, a reestruturação imobiliária se dá a partir da transformação dos usos dos espaços, por isso a ideia de "plasticidade" do espaço da metrópole. A redefinição da situação geográfica de Perus pode revelar essa plasticidade. Nesse sentido, buscaremos interpretar as recentes mudanças nas propriedades em Perus, observando-as como uma possibilidade de reprodução do capital financeiro-imobiliário.

Feita essa breve introdução conceitual, analisaremos a nova situação de Perus, caracterizada, sobretudo, pela construção do Rodoanel, por intervenções urbanísticas sustentáveis e pela existência de terrenos grandes não urbanizados que podem ser, e já são, veículos de uma renda excepcional e de um capital fictício associado.

Buscaremos, a seguir, interpretar as mudanças históricas e espaciais significativas para a compreensão do processo de reestruturação imobiliária na metrópole e, especificamente, em Perus. Visto que a situação geográfica é definida pelas mudanças posicionais de um espaço urbano específico dentro do conjunto do sistema produtor de mercadorias, parece-nos relevante uma contextualização dos elementos históricos constitutivos do espaço social de Perus. Essa descrição das circunstâncias será conduzida pelo conceito de situação geográfica.

\subsection{A produção da situacão geográfica de Perus}

Para a compreensão da mudança posicional de Perus é necessário recordar alguns momentos de seu processo de ocupação. Por mais que nosso foco maior de estudos seja o distrito de Perus, é inviável pensar essa localidade sem considerar seu entorno, que tem formação socioespacial semelhante e complementar. Assim, estaremos 
atentos aos impactos da reestruturação imobiliária no distrito de Anhanguera, e nos municípios de Caieiras e Cajamar.

Como dito anteriormente, nos dias de hoje a questão do sítio pode ser menos relevante para o entendimento da dinâmica da cidade, porém ela é essencial para se compreender a gênese de um núcleo urbano. O bairro de Perus se formou às margens do ribeirão homônimo, cujas nascentes estão a leste do Pico do Jaraguá. Suas águas correm para noroeste escavando um vale estre o maciço da Cantareira e as montanhas do Jaraguá, em direção oposta à calha do rio Tietê. O Ribeirão Perus faz parte da bacia hidrográfica do Juqueri, portanto, do ponto de vista geomorfológico, o bairro não está inserido na bacia de São Paulo.

Vindo de leste para o centro do bairro as serras alongadas do maciço da Cantareira perdem altitude e tornam-se mares de morros, caracterizando um relevo bem acidentado, com altitude variando entre 740 e 860 metros. O ponto mais baixo está na área de planície aluvial, em cujo entorno o bairro surgiu. Desse ponto, a ocupação se expandiu em direção às vertentes íngremes da bacia do Ribeirão Perus e de seus afluentes. Posteriormente, a malha urbana superou o interflúvio a oeste do Ribeirão Perus e incorporou parte da bacia do córrego das Laranjeiras à área urbanizada, outro contribuinte do rio Juqueri (ver mapa 1).

Geologicamente, a área está inserida no Grupo São Roque, composta por rochas ígneas e metamórficas variadas, além de pequenas áreas de deposição sedimentar. É relevante considerar a formação geológica da região ${ }^{12}$, pois houve, e ainda há, muita extração mineral, principalmente, destinada a servir de matéria-prima ao processo de industrialização e urbanização do Brasil. A extração mineral é uma marca na paisagem e na história da região noroeste de São Paulo. Ali encontramos minas e jazidas de caulim, feldspato, argila, areia e pedregulho além de granito, gnaisse, calcário e ouro ${ }^{13}$.

\footnotetext{
${ }^{12}$ Não apenas em Perus como também nos bairros vizinhos, Anhanguera e Jaraguá, e nos municípios vizinhos Cajamar, Caieiras, Santana do Parnaíba, Francisco Morato e Franco da Rocha.

${ }^{13}$ Sobre a formação geológica da região, ver Carneiro, 1983. Sobre a formação geológica associada à ocupação da região, ver Vellardi, 2017.
} 


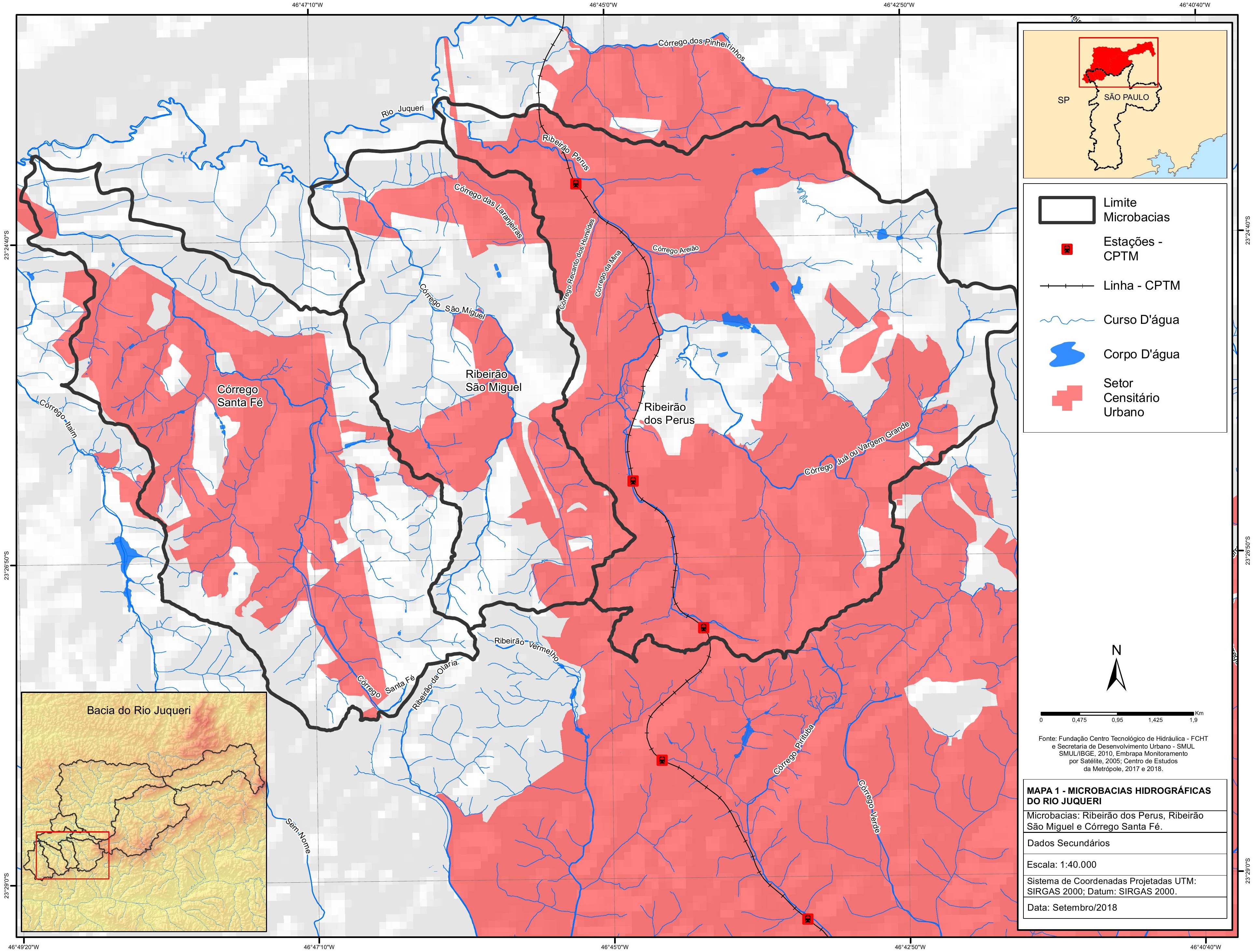


Lamentavelmente, há pouco registro documental sobre a ocupação indígena précolonial, que certamente existia na região nesse período ${ }^{14}$. Essa porção da metrópole passou as ser ocupada por colonos já no século XVI e XVII devido ao fato de haver ouro na região próxima ao Pico do Jaraguá e ao Morro Doce (distrito de Anhanguera). No entanto, essa exploração mineral não resultou em grande ocupação local, pois não foi encontrado grande volume aurífero. Vellardi (2017, p. 170) destaca que no século XIX houve uma segunda corrida atrás de ouro na região, embora pouco significativa. Entretanto, a autora relata que fora encontrado ouro de aluvião na região do córrego das Laranjeiras.

A formação do bairro de Perus tem relação com esse movimento bandeirista dos primeiros séculos da colonização, pois daí se originou o estabelecimento de algumas fazendas e sítios. Predominava o tipo de ocupação "caipira 15 " - uma população dispersa no espaço, predominantemente cabocla, que vivia praticamente em uma economia de subsistência e que habitava o entorno da cidade de São Paulo e o interior. Langenbuch (1971) afirma que a cidade de São Paulo até o século XX estava rodeada por um “cinturão caipira". Perus fazia parte desse cinturão e na época era conhecido como bairro do "Ajuá16".

A existência desses sítios de caipiras na região noroeste deu suporte à circulação de tropeiros nos tempos de colônia e império. O principal meio de transporte nesse longo período eram as tropas de mulas ou cavalos, que demoravam dias para se deslocar e, por isso, precisavam de pousos ao longo do caminho. A estrada de Goiás passava pela região noroeste de São Paulo, sendo essa "a mais importante estrada de penetração" (Langenbuch, 1971, p. 31). Assim, havia uma série de modestos pousos nesse caminho. A situação geográfica da bacia do Juqueri mostrou-se fator decisivo para o início da sua ocupação, visto ser caminho e ponto de apoio para a circulação regional.

O desenvolvimento técnico, causado pela $2^{\mathrm{a}}$ revolução industrial e a exportação de capital dos países centrais, resultou em um momento de redefinição posicional de Perus. Houve a construção da Estrada de Ferro Santos Jundiaí (EFSJ ou São Paulo

\footnotetext{
14 Além de haver registros arqueológicos de ocupação pré-colonial nessa região, atualmente existe um território indígena no Jaraguá (na fronteira com Perus), de etnia Guarani Mbye, que resiste em meio à forte pressão imobiliária. Construído ao lado dessa área e desconsiderando os indígenas, o Rodoanel Oeste acabou autuado pelo Ministério Público Federal. Para saber mais sobre esse conflito, ver FARIA, 2016.

15 Essa denominação é aqui utilizada para identificar um grupo étnico que se caracterizava por um conjunto de práticas e que esteve presente no entorno da cidade de São Paulo até o século XX. Rejeita-se, portanto, a visão preconceituosa e pejorativa difundida na literatura e no senso comum sobre os caipiras.

${ }^{16}$ Nome indígena utilizado para se referir ao Ribeirão Perus.
} 
Railway) em 1867, que estabeleceu ligação das fazendas produtoras de café do interior com o porto de Santos e, daí, com os países centrais. O traçado da ferrovia seguiu o caminho semelhante ao das tropas para Goiás, mas não coincidiu exatamente, pois os engenheiros responsáveis buscavam instalar essa estrutura de transporte paralela às áreas de várzeas, enquanto as tropas procuravam apenas cruzar esses espaços.

Perus, nesse momento, recebeu uma estação ferroviária, às margens do ribeirão. Aí, como em outras paradas do trem, constituiu-se um ponto de convergência de mercadorias e pessoas, uma pequena centralidade regional, com vendas e botequins. Langenbuch (1971) definiu essas aglomerações como "povoados-estação". Obviamente, com a chegada da estação, a região de Perus ganhou novos conteúdos correspondentes ao espaço produtivo. As categorias fundamentais do modo de produção capitalista terra, trabalho e capital - começaram a se autonomizar. A propriedade privada territorial começou a se disseminar, e junto com ela a prática da grilagem. Os caipiras que ocuparam por tanto tempo a região, começavam a perder os seus meios de vida.

Segundo Vellardi (2017, p. 88), na região noroeste da RMSP já havia extração de cal e outros minerais em 1857. No entanto, a ferrovia foi fator decisivo para a distribuição das fábricas em São Paulo, de modo que essa atividade ganhou outras proporções a partir de 1877, no (que hoje é o) município de Caieiras. A Companhia Melhoramentos ${ }^{17}$, aproveitando o acelerado processo de urbanização $^{18}$ investiu na construção de fornos de cal, às margens do rio Juqueri e se tornou a primeira indústria da região. A Melhoramentos produzia, além de cal, produtos cerâmicos, materiais minerais para urbanização (manilhas, paralelepípedos, ladrilhos, guias, sarjetas etc.). A partir de 1890, passou a produzir papel. Formou um importante centro industrial nos arredores da cidade de São Paulo.

\footnotetext{
${ }^{17}$ Cia. fundada pelo coronel Antonio Rodovalho em associação a capitalistas alemães Weiszflog, da M. L. Bühnaeds \& Cia. Em 1906 Rodovalho sai da sociedade e os alemães tornam-se donos da Cia. Melhoramentos. Hoje a empresa é um conglomerado com capital aberto na Bolsa de Valores de São Paulo e que atua nos setores de: mercado editorial, fibras de alto rendimento, gestão de florestas plantadas e projetos imobiliários. Seus projetos imobiliários estão, sobretudo, localizados nas áreas de Perus, Caieiras e Cajamar. Alguns deles serão abordados mais à frente. Por enquanto, vale destacar que o conglomerado participa de cinco empresas que atuam com negócios imobiliários: a Companhia Melhoramentos de São Paulo, que gerencia aluguéis e arrendamentos de terras; a Melius Empreendimentos Imobiliários Ltda; Manguinhos Empreendimentos Imobiliários Ltda; Space Empreendimentos Imobiliários Ltda; e a Nova Caieiras V Empreendimentos Imobiliários. As últimas quatro atuam com venda de imóveis e empreendimentos imobiliários (Informações retiradas da proposta de administração do conglomerado para os acionistas 2018. Disponível em: http://www.melhoramentos.com.br/v2/wp-content/uploads/2011/06/Proposta-daAdministra\%C3\%A7\%C3\%A3o-2018.pdf. Acessado em 10 de julho de 2018).

18 Ainda em busca de lucros com a produção da cidade, a Melhoramentos passou a investir seu capital em serviços de esgoto e água tratada para atender às crescentes demandas urbanas de São Paulo.
} 
Todos os ramos dessa indústria realizaram-se associados à proximidade das matérias-primas. A produção de papel e do próprio combustível (carvão vegetal) fez com que a Melhoramentos adquirisse uma vasta área nos arredores de Perus para plantar eucaliptos ${ }^{19}$. Também é notável que por mais que estivesse próxima, a sede industrial da Melhoramentos não estava ao lado da estação Perus, o que tornava necessário transportar as mercadorias até a ferrovia. Porém, em 1893, foi inaugurada a estação Caieiras próxima à sede da fábrica, solucionando essa questão.

Aproveitando-se da proximidade da ferrovia, inauguram-se novas fábricas e pedreiras em Perus, como a Fábrica de Pólvora de Perus (de 1894, que durou 30 anos) e o sítio Botuquara (1905), cujas pedreiras marcam a vista à leste de Perus. No ano de 1910, foi criada outra companhia de extração de cal no bairro do Gato Preto (hoje em Cajamar), também decisiva para a história da região.

A massiva imigração ocorria à pleno vapor nesse período, como um meio de forjar o trabalho assalariado e como estratégia política de branqueamento da população. Os imigrantes, espoliados em suas terras de origem, chegavam a São Paulo e, se não iam às fazendas do interior, alocavam-se onde havia indústrias. Perus era um desses destinos, onde os imigrantes passaram a conviver com os caipiras.

A alteração que a EFSJ trouxe à situação geográfica de Perus, tornou-se evidente quando, em 1926, instalou-se a maior fábrica de cimento do Brasil (na época) ao lado da estação. Essa localização industrial aliava disponibilidade de matériasprimas, transporte ferroviário, além de contar com força de trabalho mobilizada e estar próxima de um mercado consumidor de crescente demanda:

Sua localização é expressiva. Junto à ferrovia Santos - Jundiaí, que assegurava o transporte de produção a São Paulo, obtinha a matéria-prima mineral dos arredores sítios a Oeste. Para tanto construiu uma pequena ferrovia com bitola de 60 centímetros. Esta pequena ferrovia local era, até há alguns anos, franqueada ao uso público, e nas primeiras décadas do século havia sido muito utilizada por romeiros que se dirigiam a Pirapora que da estação terminal em diante seguiam a pé ${ }^{20}$ (Langenbuch, 1971, p. 107).

\footnotetext{
${ }^{19}$ As plantações de eucalipto estão presentes, em grande monta, até os dias de hoje na região de Perus (seguindo em direção a Jundiaí) e são espaços importantes para a compreensão da atual reestruturação imobiliária da região.

20 “A ferrovia Perus Pirapora foi inaugurada no ano de 1914 [por uma empresa privada] destinando-se ao transporte de cal produzido na região, mas já no ano de 1926 incorporou-se ao complexo minerador e industrial da Companhia de Cimento Portland Perus. Sua importância histórica, que é destacada desde sua desativação e tombamento pelo CONDEPHAAT em 1983, se dá por ser essa a última ferrovia do país a operar naquela bitola de 60 centímetros. Atualmente um grupo intitulado Instituto de Ferrovias e Preservação do Patrimônio Cultural (IFPPC), uma associação sem fins lucrativos, dedica-se a preservação e revitalização do acervo histórico que conta com $15 \mathrm{~km}$ de linhas férreas e todos os veículos ferroviários" (BEZERRA, 2017, p. 28).
} 
O vertiginoso processo de urbanização de algumas cidades brasileiras especialmente São Paulo - atraiu o grupo de capital transnacional Drysdale y Pease, sediado no Canadá, o qual era proprietário de grandes fábricas de cimento, como a "Lone Star Cement Company" nos Estados Unidos, entre outras no Canadá, Espanha e França (Siqueira, 2001, p. 27). Em associação, os empresários brasileiros produtores de cal do Gato Preto e o grupo Drysdale y Pease formaram a "Brazilian Portland Cement Company" ou a "Companhia Brasileira de Cimento Perus Portland S.A. (CBCPP) ${ }^{21}$ " em 1924. Todo maquinário industrial foi importado e a estrada de ferro Perus Pirapora também foi incorporada ao capital da empresa.

A figura do primeiro presidente da empresa, Dr. Sylvio de Campos (1884-1962), foi central para a realização desse projeto. Ele era um dos fundadores da empresa que extraia cal no bairro do Gato Preto. Advogado, empresário e deputado federal (1924-30 e 1946-51), era filho de Bernardino de Campos, Presidente do Estado de São Paulo de 1902 a 1904, e irmão de Carlos de Campos, que ocupou o mesmo cargo do pai entre 1924 e 1927. Dr. Sylvio era um dos elos entre os políticos brasileiros e as companhias sediadas em Montreal (Drysdale y Pease e a São Paulo Tramway, Light \& Power Company) (Siqueira, 2001, p. 32). Essa influência foi fundamental para que CBCPP pudesse se estabelecer quase que em condição de monopólio no mercado brasileiro ${ }^{22}$.

A Light construiu uma linha de alta tensão em 1925, a qual ligava Cajamar a Perus, exclusivamente para atender à demanda da $\mathrm{CBCPP}{ }^{23}$. A energia elétrica para a população do bairro como um todo só foi disponibilizada no ano de 1954. Além da

\footnotetext{
${ }^{21}$ O grupo transnacional Drysdale y Pease era o acionista majoritário, detinha $70 \%$ das ações da fábrica de Perus, pois fez um investimento inicial de aproximadamente US\$ 3 milhões (SIQUEIRA, 2001).

22 "A intensificação dos contatos em 1923 entre os empreendedores canadenses e o Dr. Sylvio de Campos coincide notavelmente com a edição, no ano seguinte, de uma medida legislativa que, pela primeira vez na história do Brasil, instituía política oficial de estímulos à instalação da indústria cimenteira. $\mathrm{O}$ maquinário requerido ficaria isento de taxas aduaneiras; o transporte de maquinas e matérias-primas contaria com tarifas especiais nas ferrovias federais e na marinha mercante. Somente se beneficiariam os projetos com capacidade mínima para produzir 30.000 toneladas/ano, que utilizassem somente matériasprimas nacionais, empregassem pelo menos $50 \%$ de brasileiros e vendessem $30 \%$ da produção para órgãos governamentais. A revogação da medida em 1927 garantiria uma situação de autêntico monopólio para a fábrica de Perus até o retorno dos mesmos incentivos em 1933" (SIQUEIRA, 2001, p. 31).

${ }^{23}$ É curioso notar as relações entre a Light e a Cimento Perus: ambas eram propriedades de sociedades sediadas em Montreal e ambas foram "assessoradas" pelos mesmos políticos para adentrar ao mercado brasileiro. Além disso, após a instalação da energia elétrica que viabilizou a existência da CBCPP, em 1926, primeiro ano de funcionamento da fábrica, $96 \%$ do cimento produzido foi sido destinado ao consumo da Light (VELLARDI, 2017). É possível questionar: seria a CBCPP parte de um conglomerado com a Light e a Cia. City em busca de criar condições para realização de uma ampla gama de negócios associados à urbanização?
} 
energia elétrica, a CBCPP também adquiriu propriedade de terras na região, onde plantava eucaliptos ${ }^{24}$ para servir de combustível.

Na década de vinte, uma série de imigrantes se desloca para Perus para trabalhar na fábrica e passa a ocupar vilas operárias, construídas tanto dentro das propriedades da CBCPP (vilas Triângulo e Portland), quanto fora delas (vilas Inácio, Operária e Hungareza). Também outros moradores não associados à indústria de cimento, mudamse para Perus em busca de terrenos mais baratos e da proximidade da ferrovia, que os levava para trabalhar em outras fábricas na cidade. Houve, portanto, uma primeira onda de comércio de terras e loteamentos das fazendas nesse período.

Nesse interim, outras famílias chegaram ao bairro, adquiriram terras e passaram a explorar os minerais, sobretudo à leste da estação ferroviária, já no sopé da Serra da Cantareira. Intensificou-se a mineração destinada à construção civil e à indústria da porcelana, que perdura até hoje. O conjunto de mercadorias de base mineral nos permite afirmar que as montanhas de Cajamar e Perus foram matérias-primas para produção do espaço urbano de São Paulo e de outras cidades no Brasil.

Uma dessas mineradoras de Perus pertencia à família Peccicacco e foi criada em 1941. Esse capital familiar adquiriu muitas terras na região, abriu pedreiras e também plantou eucalipto para usar de combustível nos seus fornos de caulim. Posteriormente, a área de silvicultura foi expandida para fornecer para a indústria do papel. A mineradora Peccicacco encerrou as atividades, mas a família ainda hoje mantém negócios com suas propriedades: arrenda as pedreiras, realiza loteamentos, negócios imobiliários e especula com a terra (como destacaremos mais adiante). Outro proprietário de muitas terras e de áreas de mineração em Perus no começo do século passado foi a família Di Sandro ${ }^{25}$.

Desse modo, podemos afirmar que nas primeiras décadas do século $\mathrm{XX}$, já estavam colocadas praticamente todas as condições para a formação de um "bairro 26 " de

\footnotetext{
${ }^{24}$ A plantação de eucaliptos foi se expandindo rapidamente com o passar dos anos na região noroeste. Segundo Langenbuch (1971) na região rural do entorno da cidade a área coberta por essa cultura cresceu mais de setenta vezes no período entre 1937 e 1960, atingindo 83577 hectares. O autor ainda afirma que provavelmente esses dados estão subdimensionados. Há fortes indícios de grilagem de terras por parte das grandes empresas que praticavam (e ainda praticam) a silvicultura na região noroeste.

${ }^{25}$ As terras dessa família foram alvo de desapropriação para a realização do Parque Linear, como será descrito no subcapítulo "A transformação dos créditos de carbono em urbanismo sustentável”.

26 Para pensar o conceito de bairro nos baseamos nas formulações de Seabra: "O bairro, na sua generalidade, mostrou-se como uma circunstância temporal da urbanização que traduz as diferentes espacializações da vida social, em função de como se integram no cotidiano, o próximo e o distante, sob o predomínio de relações imediatas, diretas. Por isso, a história urbana guarda, de cada bairro, um perfil sociocultural, resultado de uma construção histórica e social, em princípio, singular” (SEABRA, 2003a, p.
} 
subúrbio. Havia os loteamentos residenciais - a consolidação da propriedade da terra -, alguns equipamentos de serviços próximos à estação, o encontro de distintas culturas imigrantes com os caipiras, a mobilização da força de trabalho. Esse conjunto de atributos já caracterizava o local como um "subúrbio-estação". Nesse caso específico, um subúrbio industrial, com função secundária de "dormitório" para os que trabalhavam em outros locais.

Também estavam praticamente definidas as condições fundiárias que caracterizariam a região noroeste até a recente reestruturação imobiliária - em curso: as indústrias estavam consolidadas em torno do extrativismo mineral, da silvicultura e produção de papel e todas estruturadas com suas matérias-primas (eucaliptos e pedreiras) próximas às plantas industriais, fato que trouxe um predomínio de propriedades extensivas à região ${ }^{27}$. Tal característica de ocupação de terras que pode ser entendida como fator inibidor de uma maior expansão urbana industrial e residencial para a região noroeste da RMSP, que hoje se caracteriza pela existência de terrenos livres de construções (Figura 1) - uma condição ímpar na metrópole ${ }^{28}$. Atualmente, essa concentração de propriedades fundiárias extensas é, sem dúvida, um atrativo ao capital imobiliário em um momento caracterizado pela raridade do espaço.

Além desse quesito fundiário, o relevo acidentado, as áreas de preservação ambiental, a especulação imobiliária, entre outros fatores, também podem ter sido determinantes para a região Noroeste não fazer parte do contínuo de urbanização metropolitano. Outros diversos subúrbios que também eram isolados foram já conurbados à cidade. Por mais que Perus se caracterizasse por ser um bairro operário, a presença de vasto espaço rural no entorno foi marcante nas práticas socioespaciais: a caça e a agricultura eram fatos comuns, assim como a existência de chácaras, sítios e fazendas, até recentemente. O bairro de Perus encerrava em si um espaço ruralindustrial-urbano - claro que dependente da ordem distante, especialmente da cidade de

30, grifos da autora). O outro do bairro, o que o afirma na diferença, seria a cidade. Conforme avança o processo de metropolização, o bairro vai se fragmentando. Se destitui o relativo localismo, e se descaracteriza a centralidade que identificava o bairro frente à cidade. Pois com a consolidação da metropolização "Não existe mais o fora e o dentro" (ibid., p. 373).

${ }^{27}$ A Cia. Melhoramentos passou a adquirir diversos terrenos na região noroeste para a Silvicultura, sobretudo em Caieiras. Também a Cimento Perus investiu na compra de terrenos, notadamente em Perus e Cajamar. Como já destacado, também a família Peccicacco o fez.

${ }^{28}$ Em 1898, também nessa região, em Franco da Rocha, foi criado o Hospital Psiquiátrico do Juqueri em um terreno com mais de 150 hectares, enfatizando esse caráter de extensas propriedades. A existência desse hospital será abordada no capítulo 4 . 
São Paulo ${ }^{29}$.

Figura 1 - Imagem de satélite da região de Perus, zona norte de São Paulo.

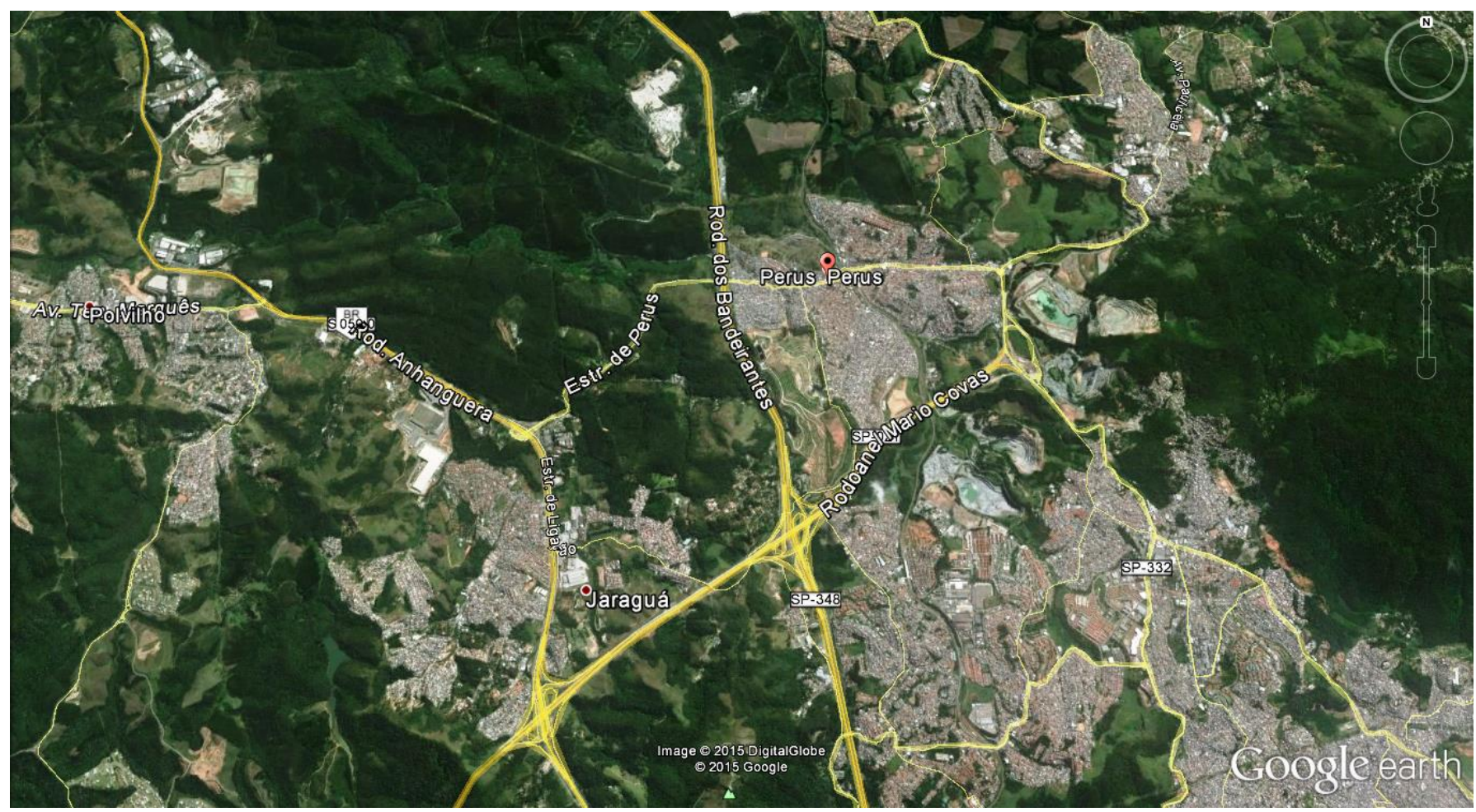

Fonte: Google Earth

Seguindo a reconstituição histórica para a compreensão da situação geográfica de Perus, é importante registrar que em 1921 um novo modal viário se instala na região: uma estrada para automóveis que ligava São Paulo à Campinas, posteriormente conhecida como "Estrada Velha de Campinas ${ }^{30 "}$ ". Já se tratava de uma tendência de privilégio do rodoviarismo como política de transportes e de modernização do Brasil. Seguindo essa tendência, em 1940, foi construída outra estrutura importante, decisiva para os conteúdos da urbanização de Perus, inclusive nos dias de hoje: a Rodovia Anhanguera, que cruza o distrito de Anhanguera. Essas vias não significaram uma mudança na centralidade do bairro, a qual estava consolidada em torno da estação e por aí permaneceu. Não houve crescimento vertiginoso de ocupações lindeiras a essas estradas - fato que pode ser interpretado pela característica fundiária da região, como já ressaltado anteriormente ${ }^{31}$.

Em 1951 ocorre um evento que posteriormente se mostraria crucial na

\footnotetext{
29 Langenbuch (1971), nos anos setenta, classificou os núcleos suburbanos isolados da cidade como "eixos de urbanização em colar", como se as várias aglomerações urbanas no entorno do espaço contínuo da cidade formassem um colar de pérolas. Para o autor, Perus seria uma das "pérolas" desse cinturão.

30 Mais recentemente, esse caminho passou a ser reconhecido como Avenida Raimundo Pereira de Magalhães, via que hoje tem tráfego intenso, ligando a Marginal Tietê ao noroeste da RMSP.

${ }^{31}$ Um fato marcante na construção da Anhanguera foi que essa via cortou o bairro do Gato Preto em Cajamar ao meio, fragmentando a dinâmica desse bairro ocupado por funcionários da CBCPP.
} 
formação social e espacial do bairro de Perus: as propriedades da CBCPP foram vendidas. Retira-se o capital transnacional e, em seu lugar, um capital nacional familiar torna-se o proprietário de todos seus bens: a ferrovia Perus-Pirapora, a fábrica de cimento, as pedreiras, o Sítio Santa Fé de silvicultura, além de tantas outras terras ${ }^{32}$. O comprador foi uma típica figura da burguesia brasileira, um proprietário de dezenas de empresas de distintas atividades: latifundiário, banqueiro, político e industrial. Seu nome era José João Abdalla $(1903-1978)^{33}$. Ficou pública e historicamente conhecido como "mau patrão", pelas condições de exploração de trabalho intensiva que exigia, e pelo mau cuidado com seus equipamentos. Até hoje, a família Abdalla detém propriedades e muitos interesses na região noroeste da metrópole, sendo, assim, um importante ator no processo de reestruturação imobiliária (como detalharemos mais adiante).

Dentre outros motivos, Abdalla foi importante para a formação do bairro, pois foi contra ele que se articulou boa parte da vida pública em Perus, através das reivindicações por melhores condições de vida e de trabalho. Essas históricas reivindicações serão abordadas no próximo subitem. O Grupo Abdalla era acusado de negligenciar o tratamento da poluição gerada pela CBCPP, além de acumular gigantescas dívidas fiscais e trabalhistas. Esses fatos levaram o Governo Federal a iniciar uma série de confiscos sobre suas propriedades, a partir de 1973. No bojo dessa recuperação por parte da União, foram estatizadas a fábrica de cimento, a ferrovia Perus Pirapora, as pedreiras e propriedades de terras na região noroeste. O Sítio Santa-Fé foi confiscado e repassado da União para a PMSP, dando origem ao Parque Anhanguera, maior parque municipal de São Paulo ${ }^{34}$. Parte desse mesmo terreno Sítio Santa-Fé foi desmembrada e utilizada pela PMSP para dar origem ao Lixão Municipal Bandeirantes, o qual mais tarde viria a se transformar em Aterro Sanitário.

A referida estabilidade do bairro e da estrutura fundiária da região passou a sofrer uma relativa reconfiguração a partir dos anos sessenta, mas nada que

\footnotetext{
${ }^{32} \mathrm{O}$ tamanho dessa propriedade fundiária, para se ter uma dimensão, é de uma área correspondente a mais 60\% do município de Cajamar. Em parte desse terreno plantou-se eucaliptos, que serviram para a empresa Copase (Companhia Paulista de Celulose), fabricante de papel do grupo Abdalla. Hoje em dia essas terras estão em intenso processo de comercialização.

${ }^{33}$ Formado em medicina, foi vereador (1931-1934) e Prefeito da cidade paulista de Birigui (1937-1941), constituinte em 1946 pelo Partido Social Democrático (PSD), Deputado Federal (1946/1950 e 1954/1964) pela mesma agremiação e Secretário do Trabalho sob o governado estadual de Ademar de Barros (19501951) (SIQUEIRA, 2001).

${ }^{34}$ A desapropriação do Sítio Santa Fé era uma pauta de luta sindicato dos "queixadas", que reivindicava a criação de um parque.
} 
descaracterizasse a concentração fundiária. Nesse período, Perus recebeu uma nova onda de migrantes, vindos, sobretudo, do espaço rural brasileiro ${ }^{35}$. Também os filhos dos antigos moradores, já crescidos, passaram a buscar áreas onde pudessem estabelecer suas moradias. Assim, a malha urbana do bairro se estendeu através de novos loteamentos, alguns considerados irregulares perante à jurisdição ${ }^{36}$.

Nos subúrbios, em geral, a classe trabalhadora passou a solucionar o problema de sua moradia através da aquisição de terrenos baratos e da autoconstrução da moradia, no seu tempo "livre" 37 . Em Perus, como em outros lugares afastados do centro, lotes foram vendidos (muitas vezes em desacordo com as leis e com zoneamento), praticamente sem nenhuma infraestrutura. Os moradores tinham que construir a própria casa e então reivindicar os serviços públicos ao Estado - um fenômeno marcante na urbanização brasileira definido como "espoliação urbana ${ }^{38}$ ".

O processo de modernização rodoviarista seguiu e, em 1978, foi inaugurada a Rodovia dos Bandeirantes ${ }^{39}$. É válido destacar que não houve grande impacto na situação geográfica com essa Rodovia, pois não havia via de acesso ao bairro de Perus $^{40}$. No entanto, essa política espacial teve impacto no processo de fragmentação do bairro, pois para sua construção foi necessário remover diversas famílias em Perus (na Vila Inácio, Cidade das Crianças e Jardim do Russo). Parte considerável dos removidos não recebeu a indenização adequada, pois não tinha a documentação legal da propriedade da terra, já que esta fora adquirida em um loteamento "clandestino" realizado pela Plavin Imobiliária. Algumas das famílias trabalhadoras expropriadas -

\footnotetext{
${ }^{35}$ Vindos de estados do Nordeste, mas também de outros lugares como Paraná, Minas Gerais etc.

${ }^{36}$ Surgem as vilas Perus, Caiuba, Osana, Flamengo e Malvina, e os jardins São Paulo, Manacá e do Russo. Na década de 1970, a Vila Nova Perus, nos anos oitenta as vilas Flamengo, Bottoni e o Jardim Adelfiore (Pelegrini, 2011). Esse último, um loteamento de um dos terrenos da família Peccicacco.

${ }^{37}$ Segundo a leitura canônica da sociologia brasileira, essa foi uma das estratégias dos capitais industriais para superexplorarem o trabalho nesse país, valendo-se de uma abundância de terras desocupadas para os trabalhadores se estabelecerem (formal ou informalmente). Dessa maneira, foi possível subtrair dos salários do trabalhador um montante razoável, correspondente ao que seria utilizado para esse assegurar sua moradia, por isso, o "tempo livre" do trabalhador também se configurava como tempo produtivo. "Dos anos 40 aos anos 70, o padrão periférico foi elemento fundamental de expansão da cidade: o migrante que chegava na região metropolitana não tinha alternativas de habitação, senão morar de aluguel, ou com parentes, e depois comprar um lote na periferia. A lógica da extensão ilimitada da cidade: loteamentos muito baratos para onde vai a população que precisa da terra como bucha de canhão..." (BONDUKI, 2001, p. 93-94).

38 “(...) somatório de extorsões que se opera através da inexistência ou precariedade de serviços de consumo coletivo que se apresentam como socialmente necessários em relação aos níveis de subsistência e que agudizam ainda mais a dilapidação que se realiza no âmbito das relações de trabalho" (KOVARICK, 1980, p. 59).

${ }^{39}$ A construção dessa moderna autoestrada cortou um grande morro em Perus e definiu a divisa entre o Parque Anhanguera e o Lixão, o primeiro à oeste dessa via e o segundo à leste.

${ }^{40} \mathrm{O}$ acesso só foi construído em 2003, com a inauguração do Rodoanel Oeste. Vale destacar que para usar esse acesso é necessário pagar um pedágio.
} 
assim definidas aqui, pois perderam a riqueza investida em suas casas - não puderam pagar por outro imóvel e foram ocupar terrenos livres em Perus. Esse movimento deu origem às primeiras favelas do bairro. Algumas delas, inaugurando as construções em áreas de várzeas de córregos no bairro ${ }^{41}$.

Consequentemente, outras famílias que moravam de aluguel na região acabaram se mudando para esses lugares, atraídos pela perspectiva de reduzir suas dificuldades financeiras ao cortar gastos com locação. Novos migrantes também passaram a ocupar as favelas.

No ano de 1980, a União levou a leilão as antigas propriedades de José João Abdalla (a Fábrica de Cimento, as pedreiras, algumas terras e a estrada de ferro Perus Pirapora). Curiosa ou contraditoriamente, o Grupo Abdalla foi o vencedor desse leilão e retomou suas antigas propriedades, agora não mais sob a direção do falecido João José, e, sim, de seu sobrinho Antonio João Abdalla Filho (conhecido como "Toninho Abdalla"). Entretanto, nesse período, a fábrica passou a ter uma produção cada vez menor. A Estrada de Ferro Perus Pirapora e as pedreiras foram desativadas pelo novo patrão em 1983. A Companhia Brasileira de Cimento Portland passou, então, a ser uma mera moedora de clínquer ${ }^{42}$, o qual vinha da Companhia de Cimento Santa Rita (grupo Votorantim). Em 1987, a CBCPP é desativada definitivamente ${ }^{43}$.

O problema básico da Gestão José João Abdalla estava na impossibilidade de ascender a um patamar superior de acumulação e concentração de capital, conforme exigido pela lógica inerente à indústria de cimento no contexto de aumento exponencial de demanda em 1967- 1980 (Siqueira, 2001, p. 121).

A gestão do Grupo Abdalla não foi capaz de resistir à reestruturação produtiva caracterizada pela concentração de capital no setor do cimento. A tese central defendida por Siqueira (2001) é que essa empresa buscou compensar sua menor produtividade através da superexploração dos trabalhadores ${ }^{44}$ e do desgaste exagerado das máquinas, sendo essa sua estratégia para defender os seus níveis de lucratividade. O evento do fechamento da CBCPP pode ser entendido como um indicador de um período de desconcentração industrial e desindustrialização que a cidade de São Paulo passou a viver.

\footnotetext{
${ }^{41}$ Segundo depoimento de Janaína, militante da Ceb, respondendo a uma pergunta sobre esse tema, apresenta uma visão contrária a mais comum sobre "invasão de terras": "não sei como foi em outros lugares, mas aqui em Perus foi assim: o Estado que invadiu um lugar que era deles (moradores), que tinham comprado terreno".

${ }^{42}$ Clínquer é o cimento em fase básica de fabricação.

${ }^{43}$ Entretanto, há que se ressaltar que o terreno e o edifício da fábrica até hoje pertencem ao Grupo Abdalla.

${ }^{44}$ Fato que gerou um processo de identificação dos moradores do bairro através das lutas ocorridas contra Abdalla, como veremos no próximo item.
} 
Nesse instante, a reestruturação produtiva estava já em andamento e, consequentemente, a reestruturação espacial urbana também. Para efeito de análise, demarcaremos a década de 1980 como fim de um ciclo socioespacial em Perus - tanto pela fragmentação do bairro e consolidação da metropolização, quanto pela mudança da sua situação geográfica em relação ao entorno metropolitano e regional.

Nosso objetivo é analisar um momento mais atual da posição urbana de Perus, no qual avançam políticas neoliberais, de desconcentração industrial, desindustrialização e aprofundamento da "crise do trabalho" (Kurz, 1992). O encerramento das atividades da CBCPP nos servirá de marco de transição entre períodos. Vale ressaltar que essa separação é apenas analítica e busca ter fins explicativos, tendo-se clareza de que os momentos de transição não são tão marcados e abruptos. Antes mesmo do fechamento da fábrica, já havia indícios de uma reestruturação imobiliária, assim como até os dias de hoje se preserva alguma identidade socioespacial no bairro.

Antes de analisar a redefinição da situação geográfica e a implosão da vida de bairro, é necessário dar destaque, mesmo que breve, às lutas trabalhistas e às lutas por melhores condições de vida urbana travadas pelos moradores de Perus ao longo do século XX. As quais, sem dúvida, tiveram papel definidor na formação da identidade desse bairro.

\subsection{A formacão da vida de bairro a partir de lutas sindicais e por condicões de vida urbana}

É possível afirmar que Perus, enquanto um espaço de representação, está diretamente relacionado com lutas sindicais e sociais. Elas foram um dos fatores que forjaram uma identidade cultural entre imigrantes nacionais, internacionais e caipiras. Grande parte da vida pública do bairro girou em torno de tempos cotidianos de organização, formação, agitação e enfrentamento político. Perus é facilmente identificado como um bairro operário, mas, sobretudo, como local dos Queixadas. Posto isso, buscar-se-á expor alguns acontecimentos que foram definidores no movimento de formação do "bairro ${ }^{45 "}$ "

\footnotetext{
${ }^{45}$ Parte-se da leitura realizada por Seabra (2013a) sobre de bairros e o processo de metropolização de São Paulo. Não se busca aqui fazer uma detalhada genealogia do bairro de Perus, pois esse não foi o foco principal de nossa pesquisa e, para tanto, seria necessário uma investigação muito mais aprofundada. No entanto, julgamos necessário contextualizar alguns conteúdos históricos e culturais da formação desse bairro para uma melhor compreensão das disputas que estão em jogo atualmente. Desse modo, nos dois
} 
A partir de depoimentos de moradores mais antigos de Perus, é possível notar que, em um momento histórico que precede o atual, existiu uma relativa identidade socioespacial e um sentimento de bairro nesse espaço, e que, com o passar dos anos, essa coesão foi se fragmentando. As determinações da Igreja e do mundo do trabalho foram centrais na definição dos conteúdos qualitativos da vida desse bairro. Sem dúvida, a fábrica de cimento foi o elemento aglutinador local, sob o qual orbitavam diversas outras atividades do bairro.

Essa espécie de "unicidade" local também se afirmava dado o isolamento de outras localidades e a distância para o centro da cidade - mais de 20 quilômetros em linha reta. Segundo o morador João Silva, no passado não se distinguia muito bem o que era trabalho, moradia ou vida cotidiana em Perus: "não era claro onde começava um e acabava o outro".

Alguns espaços foram importantes para realização da sociabilidade local, como a Paroquia Santa Rosa de Lima, as Comunidades Eclesiais de Base (Ceb), os dois cinemas, os campos de futebol, as vendas, e o sindicato entre outros locais onde ocorria a vida pública em Perus. E alguns momentos foram marcantes para a identidade local, especialmente aqueles que surgiram e se desdobraram da atividade sindical.

O Sindicato dos Trabalhadores do Cimento, Cal e Gesso de São Paulo foi fundado em 1933. No entanto, foi a partir dos anos cinquenta que esse passou a exercer uma centralidade na vida de bairro. O ano de 1958 nos parece um ponto de inflexão na história do sindicato e vida do bairro. Os trabalhadores da CBCPP entraram em greve reivindicando aumento salarial. No entanto, exigiam que esse ganho não impactasse de forma desproporcional no preço final do cimento, de modo a prejudicar a população em geral. A fábrica ficou paralisada, enquanto os trabalhadores e moradores de Perus se organizaram em campanha para ganhar a opinião pública através da mensagem “estamos dispostos a ganhar menos, se o preço do cimento baixar" (Jesus, 1992, p. 30). A greve surpreendeu a todos, pois aconteceu algo que ia contra os valores capitalistas individualistas: operários estavam arriscando seu emprego em luta pelo "bem comum" da sociedade, isto é, para que a ganância dos capitalistas do cimento não recaísse sobre a população.

Foram 46 intensos dias em que a vida do bairro se voltou para a mobilização trabalhadora. Não apenas operários estavam agindo em prol da greve, mas também 
mulheres e crianças participavam ativamente de piquetes, passeatas na cidade, visitas a escolas, universidades e outras fábricas, entre outras formas de ajuda. As assembleias, por serem muito grandes, passaram a se realizar no cinema de Perus e não no sindicato.

A greve foi vitoriosa: garantiu $40 \%$ de aumento salarial - nos termos propostos pelo sindicato - e que nenhum trabalhador fosse demitido. O povo de Perus e o sindicato se empoderaram e se aproximaram nessa jornada. Nessa luta, surgiu a designação de Queixadas ${ }^{46}$ para os militantes da fábrica de cimento. Esse momento foi tão marcante que após a greve se construiu uma nova sede para o Sindicato em sistema de mutirão, com apoio dos moradores e sem dinheiro público.

Derrotado, o "mau patrão" demitiu, em 1959, 80 trabalhadores que iriam completar 10 anos de casa e assim atingiriam a estabilidade, como forma de represália. O poder de coesão dos Queixadas estava tão alto que logo fizeram um dia de greve, o patrão recuou, e os trabalhadores tiveram seus empregos garantidos ${ }^{47}$.

Já identificado por lutas inovadoras como a corajosa paralisação pelo "bem comum", o sindicato de Perus encampou outras lutas que desafiavam a ordem estabelecida para a distribuição da mais-valia de uma empresa. Dentre outras ações, reivindicaram: o aumento salarial para o funcionário que tinha uma esposa (“dona-decasa") e filhos - chamado de "salário família"; o aumento salarial variável atrelado à maior produção da fábrica - chamado de "prêmio-produção"; a construção de mais moradias nas terras da empresa, porque as vilas operárias já não comportavam a todos. Essas exigências foram acatadas pelo proprietário da fábrica, sob ameaça de nova greve - no entanto, algumas delas nunca foram cumpridas, como, por exemplo, a construção das novas moradias.

A organização radical de Perus teve influência teórica direta de Padre Lebret ${ }^{48}$, Mahatma Gandhi e Martin Luther King Jr. (entre outros) e construiu sua linha de ação a partir do pressuposto de "não-violência". Os sindicalistas de Perus traduziram esse ideal de "não-violência" através do slogan "firmeza permanente", que pensaram manifestar

\footnotetext{
${ }^{46}$ Queixada é uma referência à espécie de porco do mato que quando se sente ameaçado se une em grupos e enfrenta o seu predador através de um ataque coletivo. Os trabalhadores da CBCPP ganharam esse apelido devido à forte união que mantiveram diante das adversidades de uma greve.

47 Todas as greves e jornadas de luta que serão descritas aqui tiveram uma série de detalhes que não convém ser esmiuçada aqui. Para mais informações sobre as greves e a atividade sindical ver: Jesus, 1992.

48 Principalmente a partir da leitura do livro "Princípios para a ação" do referido padre francês. O advogado do sindicato, entre 1954 e 1973, Mário de Jesus, foi responsável por introduzir essas ideias para os trabalhadores CBCPP. Jesus participou do grupo do padre Lebret na França em 1947, além de trabalhar em uma fábrica por lá, onde conheceu a vida sindical e prática de um engajamento social inspirado pelo Evangelho (JESUS, 1992, p. 26).
} 
melhor a prática Queixada. Tratava-se de uma tática de enfrentamento que se colocava como ativa, mas fugia do estereótipo disseminado pelo Estado e pelos capitalistas de que a luta sindical é irracional ${ }^{49}$. Esse movimento sindical era tributário das ideias de “democracia cristã" e estava associado à Frente Nacional do Trabalho (FNT). Para o desenvolvimento das práticas políticas e sindicais locais, havia grupos de formação e estudo no bairro.

Assim, as lutas de Perus continuaram a crescer nos anos 1960 e ficaram consagradas na história. Em 1962, 3.500 funcionários de cinco diferentes empresas do Grupo Abdalla ${ }^{50}$ entraram em greve. Após 32 dias de paralisação, o "mau patrão" atendeu as reivindicações de três empresas, mas se recusou a negociar com a Copase e com a CBCPP: tratava-se de uma perseguição política aos trabalhadores de Perus e Cajamar pelas lutas anteriores. Essa perseguição se transformou em uma acirrada disputa, por mais de sete anos.

Os Queixadas, que haviam entrado em greve também por solidariedade às outras categorias, resolveram não recuar e se mantiveram paralisados, então, com uma pauta de sete reivindicações específicas. E, ainda mais, propunham que, caso não fossem atendidas as pautas, o governo desapropriasse a fábrica de cimento. 1400 trabalhadores permaneceram paralisados e a produção não ocorreu por 100 dias, até que com forte auxílio policial, Abdalla conseguiu fazer as máquinas e as pedreiras funcionarem através da mão de obra de trabalhadores "fura-greve" de outras empresas. Passado mais um mês, 1.200 trabalhadores, que se mantinham de braços cruzados, foram demitidos, inclusive os que tinham atingido estabilidade. A ofensiva do "mau patrão" feria os Queixadas, que viveram tempos muito difíceis, mas ainda assim se mantiveram unidos na luta.

Todos os habitantes de Perus estiveram relacionados com essa mobilização sindical, evidentemente, nem todos do mesmo lado. No dia-a-dia do bairro, a população do bairro se dividiu entre os Queixadas e os "pelegos" (aqueles que furaram ou não apoiaram à greve), mas, de uma forma ou de outra, todos tiveram que se posicionar. Abdalla pressionava os comerciantes de Perus a não venderem mercadorias para as famílias Queixadas. Esses, por sua vez, recebiam doações da sua rede de apoio do bairro e do país para abastecer os grevistas. Um exemplo de solidariedade na greve foi do dono

\footnotetext{
${ }^{49}$ Para mais informações sobre a não-violência ou a firmeza-permanente dos Queixadas, ver Jesus, 1992. ${ }^{50}$ As empresas paralisadas, além da Cimento Perus, foram: Usina Miranda (Pirajuí/SP), Tecelagem Japy (Jundiaí/SP), Fábrica de Papel Carioca (Jundiaí/SP) e Copase (Cajamar/SP).
} 
da padaria de Perus que cedia seu forno para que os Queixadas pudessem fazer pão. As mulheres que tinham papel ativo na mobilização, passaram a trabalhar com costura ou outro serviço para garantir o sustento e a continuidade da luta. As reuniões continuaram acontecendo no cinema e nas paróquias de Perus e Cajamar, traçando estratégias de resistência. Manifestações, contatos com autoridades, piquetes, palestras, abaixoassinados, campanhas pela desapropriação da fábrica, entre outras ações, eram realizadas. Até greve de fome de um mês foi realizada em pleno Largo São Francisco (no centro da cidade).

Com o golpe militar em 1964, a repressão se acentuou: houve intervenção no sindicato, ocupação militar em Perus e Cajamar e vários dirigentes presos. Abdalla ameaçava despejar os trabalhadores que moravam nas vilas operárias.

Mesmo assim, a luta dos Queixadas continuou e percorreu longo trâmite judicial. Finalmente, em 1969, o Tribunal Superior do Trabalho reconheceu que a greve era justa e determinou a reintegração dos 501 trabalhadores estáveis aos seus antigos postos, recebendo seus salários atrasados com juros e correção monetária, além de uma indenização. Os trabalhadores não-estáveis receberiam seus salários atrasados, mas deveriam reintegrar à empresa. Houve, então, um acerto entre os Queixadas, de que parte das indenizações seria redistribuída com não-estáveis, como uma tentativa de ser mais justo com todos os militantes que foram mais prejudicados.

Essa greve é considerada a mais longa da história, por ter durado sete anos e quatro meses ${ }^{51}$, sendo, ao final, reconhecida pela Justiça do Trabalho como vitoriosa. Foi uma das mais importantes movimentações sindicais brasileiras. E, em sua vitória, foi determinante o apoio dos moradores do bairro.

No entanto, Abdalla passou anos sem cumprir a determinação da Justiça. Somente em 1975, com a fábrica sob gestão da União - após o confisco dos bens de Abdalla em 1973 - é que houve o pagamento dos 7 anos de salários atrasados para os grevistas, que receberam o dinheiro em frente ao sindicato sob a luz de velas e, então, puderam voltar a trabalhar na fábrica. Vale ressaltar que a desapropriação dos bens de Abdalla, por mais que seja controversa, foi uma vitória dos Queixadas, pois foi desse sindicato que surgiu a denúncia e a campanha para que o Estado controlasse a fábrica.

É importante destacar que a identidade de luta do bairro de Perus não se restringiu exclusivamente aos direitos trabalhistas, mas também às reivindicações por

\footnotetext{
${ }^{51} \mathrm{O}$ tempo de mobilização foi esse, no entanto, a produção esteve parada por consideráveis 100 dias.
} 
melhores condições de vida urbana. Nesse sentido, a Igreja teve papel central como espaço de diálogos e encontros entre os moradores. Aliás, a Igreja foi fundamental para a organização dos Queixadas, não só pela influência do Padre Lebret, como também pelo suporte dado pela Paróquia e pelas CEB.

A partir dos anos 1960, pautada pela "Teologia da Libertação 52 ", a Igreja de São Paulo passou a construir centros comunitários nos bairros, as CEB. Em Perus, esses espaços, além de apoiar e difundir as lutas dos Queixadas, também fomentaram grupos de reflexão sobre fé e política. Também foram palco do surgimento de associações de moradores que se organizavam para reivindicar melhores serviços de consumo coletivos (como água encanada, energia elétrica, escolas, pavimentação, etc.). Quando começam a surgir as favelas nos anos setenta, nascem também as pastorais de favelas. Das mulheres da Igreja também surgem as organizações de Clubes de Mães, entre outros grupos de autogestão da vida cotidiana. Nesse momento, existia uma influência mútua entre as ações tomadas pelos Queixadas e pelas $\mathrm{CEB}^{53}$. Havia uma vida comunitária baseada na luta contra as opressões urbanas e trabalhistas.

Outra importante mobilização ocorreu nos anos setenta, quando, a partir da Campanha da Fraternidade da Igreja Católica, a população começou a se organizar contra a poluição da CBCPP, que atirava pó de cimento sobre o bairro. Durante anos, a população de Perus teve que varrer o quintal que se enchia de pó. As roupas no varal e as plantas também se sujavam. Era necessário fazer manutenção periódica dos telhados que se quebravam por conta do cimento. Além disso, o pó gerava doenças respiratórias nos moradores. As mulheres do bairro, então, lideraram a campanha " $\mathrm{O}$ pó de cimento esmaga a vida". Foi uma luta por melhores condições de vida e de saúde para os moradores do bairro. Posteriormente, esse movimento ficou conhecido como um dos primeiros atos ambientalistas do Brasil - o que nos parece uma inferência anacrônica. Entretanto, esse momento foi marcante na vida do bairro de Perus e continua importante para a compreensão da disputa da memória do bairro, que está em curso atualmente. Esse assunto será melhor debatido no subtítulo "Os interesses em torno da Fábrica de Cimento e da memória do bairro", no capítulo 3.

Uma última jornada de lutas merece destaque, pois metaforicamente simboliza a reestruturação produtiva atingindo a vida dos trabalhadores e um ponto de ruptura na

\footnotetext{
${ }^{52}$ Organização progressista da Igreja Católica que pregava a formação política e crítica dos seus fiéis, na luta contra a opressão vivida pelas parcelas mais pobres da população.

${ }^{53}$ Um exemplo disso é que o grande líder operário, João Breno, também participava do conselho paroquial.
} 
vida de bairro. Em 1984, a CBCPP já tinha diminuído consideravelmente sua capacidade produtiva e seu quadro de funcionários. Nesse ano, a Votorantim ${ }^{54}$ deixou de mandar o clínquer para Perus, por falta de pagamento do grupo Abdalla. Os Queixadas, temerosos de perder seus empregos, mobilizaram-se para que a fábrica não fechasse e conseguiram um financiamento com o Banespa para que a matéria voltasse a ser entregue pela Votorantim. A crise do trabalho atingiu em cheio os operários de Perus, e suas antigas estratégias sindicais já se mostravam insuficientes para os novos problemas, tendo sido necessário "socorrer" o patrão nesse caso.

Em 1986, na última greve da CBCPP, os Queixadas lutavam por equiparação salarial com os operários da Votorantim, que ganhavam o dobro dos trabalhadores da Perus. Toninho Abdalla se negou ao diálogo e, a exemplo de seu tio, demitiu todos funcionários que entraram em greve. Com menor força política dos trabalhadores, os casos foram para justiça, sendo julgados individualmente. Alguns funcionários ganharam a causa e foram reincorporados à fábrica, enquanto outros não. Mas os que voltaram, nada tiveram para fazer, pois Abdalla estava "vendendo as máquinas a preço de sucata" (JESUS et al.,1992, p. 79).

A partir de então, a luta do sindicato passou a ser novamente pela desapropriação da fábrica, que contraiu mais dívidas trabalhistas com essa greve e que já estava se desfazendo de suas forças produtivas. Até 1992, a proposta sustentada pelo sindicato era que houvesse uma gestão conjunta da produção entre os operários e o Estado. A proposta até avançou politicamente, durante a gestão da prefeita Luiza Erundina ${ }^{55}$, mas não se realizou. $\mathrm{O}$ sindicato, em coerência com seus atos anteriores, propunha uma autogestão operária da CBCPP, sob chancela do Estado, cujo interesse público seria o de vender cimento a preços baratos (o slogan era "cimento barato para sair do barraco"), pois assim seria possível quebrar o "cartel do cimento" que controlava os preços. Até os dias de hoje, o sindicato de Perus atua politicamente na linha de desapropriar a CBCPP, não mais para produzir, mas para formar um centro de memória do trabalhador.

Observa-se uma perda de poder agregador da luta sindical no bairro, já nos anos oitenta. Simultaneamente ao fechamento da fábrica, Perus vive uma explosão demográfica, o que indica uma ruptura na lógica socioespacial. Afinal, são dois fenômenos aparentemente contraditórios, que representam um momento de

\footnotetext{
${ }^{54}$ Empresa que estava consolidando sua centralização de capital no ramo cimenteiro e utilizando a estrutura da fábrica de Perus como mera moedora de clínquer.

55 Prefeita entre 1989 e 1993, então filiada ao Partido dos Trabalhadores.
} 
fragmentação do bairro e reestruturação imobiliária.

\subsection{A fragmentação do bairro}

$\mathrm{O}$ processo de encerramento das atividades da CBCPP significou uma diminuição da oferta de empregos diretos e indiretos no próprio bairro. Seria razoável pensar que essa parte "isolada" da cidade se tornaria um lugar obsoleto, abandonado, e que os habitantes que ali se encontravam teriam de se deslocar para outras regiões. Contudo, ao contrário do que se poderia esperar, concomitantemente a esse fato, houve um forte crescimento populacional nessa parte da cidade (Tabela 1).

Esse fato, em parte se explica porque as determinações que levavam as pessoas a morar em Perus já não eram tanto ligadas aos empregos na região, mas sim às possibilidades de acesso a um imóvel barato, ou, até, à possibilidade de ocupar terrenos livres. Mesmo sendo um local relativamente afastado do centro, um dos atrativos de Perus foi a conciliação entre o acesso à terra (a um custo relativamente baixo) e a proximidade de meios de transportes públicos, graças à existência da ferrovia que leva à estação Barra Funda ou Luz em menos de uma hora. Além disso, nessa época, algumas (poucas) linhas de ônibus também podiam transportar as pessoas para regiões com maior oferta de emprego, como, por exemplo, o Terminal Princesa Isabel ou Pinheiros $^{56}$.

Nos anos 1980, a questão da moradia se agravou em São Paulo, sob um contexto de crescente crise do trabalho e desconcentração industrial, que resultou no aumento do desemprego estrutural. Esse fenômeno, associado à raridade do espaço e ao aumento dos preços imobiliários, gerou agravamento das condições de moradia da classe trabalhadora. No momento histórico antecedente, o loteamento irregular de terras, aliado ao autoempreendimento da moradia, foi uma forma indireta para a superexploração dos empregos industriais. Porém, para o período em questão (últimas décadas do século XX e início do XXI), faz-se necessário repensar essa formulação, já que o trabalho formal é cada vez mais raro ou precarizado:

(...) o "padrão periférico estava esgotado" (...) Nos anos 80, isso começou a não funcionar mais. Milhares de pessoas não conseguiam mais comprar um lote, porque a terra ficou cara, as terras baratas estavam muito distantes, os custos de transporte muitas vezes inviabilizavam a ocupação e houve crise econômica, ocasionando despejos, um forte arrocho salarial e o aumento do desemprego. Aí

\footnotetext{
${ }^{56}$ Atualmente, o bairro é mais bem servido por linhas de ônibus, mas ainda não de maneira suficiente para suprir as necessidades da população local.
} 
começaram a crescer as favelas e os movimentos sem-terra (BONDUKI, 2001, p. 94).

Nesse contexto, a prefeita Luiza Erundina, contemplando às demandas desses movimentos sociais, adquire um vasto terreno desocupado em Perus e inicia um programa habitacional de construção por meio de mutirão, em 1992. Paulo Maluf, prefeito sucessor $^{57}$, no entanto, interrompeu esse programa. Mas a ocupação do terreno não cessou, e se deu, então, sem assessoria técnica e materiais adequados. Assim, surgia o Recanto dos Humildes.

Após o período do mutirão, a PMSP tentou evitar a ocupação através de reintegração de posse e destruição dos barracos. No entanto, o ritmo de construção da população foi tão acelerado que a PMSP não pôde acompanhar. A partir de então, a ocupação passou a se consolidar, com serviços públicos, comércios e se expandiu de uma vez por todas nos anos seguintes ${ }^{58}$.

Nas duas últimas décadas do século, a população da subprefeitura de Perus quase triplicou. Entre os anos 2000-2010, essa foi a região administrativa que teve o maior crescimento demográfico relativo entre todas as 32 subprefeituras. Entre 19902000, foi a segunda maior (ver Tabela 3). Esse dado é significativo, pois indica que essa é uma das regiões onde vem ocorrendo a expansão urbana da metrópole.

A maioria das pessoas que chegaram nos anos noventa, foram migrantes nordestinos. O Recanto foi o principal local que recebeu essas pessoas, mas também outras áreas foram sendo ocupadas, especialmente no Jardim do Russo e Vila Caiuba. Além disso, o distrito de Anhanguera, que tinha pouquíssima ocupação urbana, também passou a se adensar nesse período ${ }^{59}$, basicamente através de loteamentos irregulares e ocupações de terras ${ }^{60}$. Evidentemente, a população que chegava, era majoritariamente pobre, de modo que Perus passou a contar cada vez mais com uma paisagem e vida cotidiana típicas de um bairro periférico da metrópole ${ }^{61}$. Essa região, que já não contava

\footnotetext{
${ }^{57}$ Prefeito de São Paulo entre 1993 e 1996, pelo Partido Democrático Social.

${ }^{58}$ Hoje o Recanto do Humildes é classificado pelo poder público como um "Núcleo Urbanizado". Essa denominação adotada pela PMSP identifica favelas que possuem infraestrutura de água, esgoto, iluminação pública, drenagem e coleta de lixo.

${ }^{59} \mathrm{Na}$ verdade, grande parte do crescimento populacional relativo da subprefeitura de Perus foi puxado pelo distrito de Anhanguera. Nesse local, que era completamente rural há poucas décadas, muitas terras foram sendo urbanizadas. A existência de vastos terrenos livres nesse distrito indica que o crescimento demográfico continuará nos próximos anos.

${ }^{60}$ Em 2002, mais de 40 famílias do MST (Movimento Sem Terra) montaram o acampamento Irmã Alberta em um terreno no quilometro 27 da Anhanguera, em uma fazenda abandonada cuja propriedade é da Sabesp. Desde então, essas famílias buscam ser o primeiro assentamento no município de São Paulo.

${ }^{61}$ Lembrando que os loteamentos irregulares e as primeiras favelas se iniciaram algumas décadas antes em Perus, no entanto, nesse período, o fenômeno atingiu patamares massivos. No ano 2000, a população
} 
com muitos equipamentos públicos, ficou ainda mais carente devido ao incremento populacional.

Tabela 1 - População na Subprefeitura de Perus e em seus distritos

\begin{tabular}{|c|c|c|c|c|c|c|c|}
\hline Ano & $\mathbf{1 9 5 0}$ & $\mathbf{1 9 6 0}$ & $\mathbf{1 9 7 0}$ & $\mathbf{1 9 8 0}$ & $\mathbf{1 9 9 1}$ & $\mathbf{2 0 0 0}$ & $\mathbf{2 0 1 0}$ \\
\hline Anhanguera & 429 & 1.030 & 2.626 & 5.350 & 12.408 & 38.427 & 65.859 \\
\hline Perus (Distrito) & 4.363 & 6.955 & 20.815 & 36.196 & 46.301 & 70.689 & 80.187 \\
\hline $\begin{array}{c}\text { Perus } \\
\text { (Subprefeitura) }\end{array}$ & $\mathbf{4 . 7 9 2}$ & $\mathbf{7 . 9 8 6}$ & $\mathbf{2 3 . 4 4 2}$ & $\mathbf{4 1 . 5 4 6}$ & $\mathbf{5 8 . 7 0 9}$ & $\mathbf{1 0 9 . 1 1 6}$ & $\mathbf{1 4 6 . 0 4 6}$ \\
\hline
\end{tabular}

Fonte: IBGE - Censos Demográficos, 1950, 1960, 1970, 1980, 1991, 2000, 2010; Sinopses Preliminares dos Censos Demográficos de 1950 e 1960; SMDU / Dipro - Retroestimativas e Recomposição dos Distritos para os anos 1950,1960 e 1970; Elaboração: Secretaria Municipal de Desenvolvimento Urbano / SMDU - Departamento de Estatística e Produção de Informação / Dipro - Disponível em:

http://smul.prefeitura.sp.gov.br/historico_demografico/tabelas/pop_dist.php, acessado em 21 de agosto de 2017.

\section{Tabela 2 - Crescimento populacional na Subprefeitura de Perus e em seus distritos}

(em \%)
\begin{tabular}{|c|c|c|}
\hline Ano & $\mathbf{1 9 9 1} / \mathbf{2 0 0 0}$ & $\mathbf{2 0 0 0} / \mathbf{2 0 1 0}$ \\
\hline Anhanguera & 13,38 & 5,54 \\
\hline Perus (Distrito) & 4,81 & 1,27 \\
\hline Fonte: IBGE - Censos Demográficos 1991, 2000, 2010; Secretaria Municipal de Desenvolvimento Urbano / \\
SMDU - Departamento de Estatística e Produção de Informação / Dipro
\end{tabular}

Tabela 3 - As três subprefeituras que tiveram maior crescimento populacional em São Paulo nas décadas de 1991/2000 e 2000/2010 (em \%)

\begin{tabular}{|c|c|c|c|}
\hline & $\mathbf{1 9 9 1} / \mathbf{2 0 0 0}$ & & $\mathbf{2 0 0 0} / \mathbf{2 0 1 0}$ \\
\hline Cidade Tiradentes & 7,89 & Perus & $\mathbf{2 , 9 6}$ \\
\hline Perus & $\mathbf{7 , 1 3}$ & Parelheiros & 2,29 \\
\hline Parelheiros & 6,79 & Campo Limpo & 1,84 \\
\hline
\end{tabular}

Podemos inferir que as políticas neoliberais, implantadas nos anos noventa para enfrentar a crise capitalista, levaram a expansão da malha metropolitana, em todas direções suburbanas. Em Perus, as enormes propriedades não urbanizadas, passaram a ser pressionadas pelas ocupações. Em 1997, por exemplo, um sítio sem uso da família 
Peccicacco, de aproximadamente 1,5 milhão de metros quadrados foi ocupado por mais de 3.000 pessoas sem teto. Houve a reintegração de posse e a família de proprietários resolveu tomar medidas temendo novas ocupações:

Mesmo depois da desativação da mineração, os eucaliptos continuavam a ser plantados com a finalidade de proteger a propriedade contra invasores. No entanto, houve a invasão e a devastação das árvores. Desde então, a área está mais protegida, vigiada por seguranças contratados pela Família Peccicacco, permanentemente ${ }^{62}$.

Esse trecho, contido no site da família, torna evidente que a utilização da silvicultura de eucalipto na região é também uma forma de especulação imobiliária ${ }^{63}$. A família Abdalla, além dos eucaliptos, igualmente, já contratou seguranças para fiscalizar suas propriedades inutilizadas contra as ocupações - inclusive na área da antiga CBCPP.

Também nos anos noventa, o Estado construiu conjuntos habitacionais (CDHU e $\mathrm{COHAB}$ ), ao norte do distrito, iniciando a verticalização em Perus. Podemos afirmar que através desses programas habitacionais citados e do mutirão, o Estado foi um indutor da expansão urbana e do aumento populacional. O bairro se transformou rápida e intensamente. Os antigos armazéns próximos à estação de trem fecharam e o comércio local passou a dividir espaço e, também, ser substituído, pelas grandes redes comerciais como Casas Bahia, Lojas Cem, O Boticário, Magazine Luiza, Subway, Supermercado Dia (no imóvel onde era um dos cinemas do bairro), entre outras. Os principais bancos também aí instalaram agências: Itaú, Bradesco, Banco do Brasil ${ }^{64}$.

Nesse momento, inicia-se uma política de tombamento de construções históricas nessa região de Perus, como um meio de se buscar proteger parte da memória do local diante das mudanças espaciais tão intensas causadas pela metropolização. Em 1987, é tombada a Estrada de Ferro Perus-Pirapora, pelo Conselho de Defesa do Patrimônio Histórico, Arqueológico, Artístico e Turístico (CONDEPHAAT). Em 1992, a Fábrica de Cimento, pelo Conselho Municipal de Preservação do Patrimônio Histórico, Cultural e Ambiental da Cidade de São Paulo (COMPRESP), declarando partes do edifício como merecedoras de proteção parcial (fachadas e volumetria) e em outras instalações como de proteção integral. No ano de 2010, também a Estação Perus

\footnotetext{
${ }^{62}$ Disponível em: < http://fiorellipeccicacco.com.br/as_terras_19.html> acessado em 23 de julho de 2018.

${ }^{63}$ Em 2003, outra área vazia da família Peccicacco, colada ao recém-inaugurado Rodoanel, foi ocupada por sem teto e, em seguida, desocupada pela polícia. Essa mesma área, posteriormente, foi especulada como um potencial Centro Logístico Metropolitano pelo Plano de Bairro de Perus (ver capítulo 3) e, atualmente, esse terreno está sem uso.

${ }^{64}$ A população local, predominantemente empobrecida, pôde se tornar consumidora de algumas dessas mercadorias que não acessava antes, especialmente por conta do acesso ao crédito.
} 
de trem foi tombada pelo CONDEPHAAT. Todos os tombamentos foram frutos de mobilização e organização da população de Perus e apoiadores.

Nesse movimento, a característica "provinciana" de Perus se perdeu definitivamente. Aquele pequeno núcleo urbano industrial, totalmente rodeado por áreas rurais, havia se perdido. Os espaços de sociabilidade mais tradicionais foram se esvaziando. Além das "vendas" como ponto de encontro, os campos de futebol também foram sumindo. O sindicato já não tinha uma categoria para representar em Perus, e não tinha o mesmo poder de aglutinação. Os cinemas foram fechados ${ }^{65}$. As CEB também perderam poder de atuação. A vida pública em Perus foi se fragmentando.

A ausência de vínculo com o espaço também se agravou porque novas pessoas encontraram poucos lugares de sociabilidade: "culturalmente, não tinha espaços de encontro, o cinema não existia mais, não tinha teatro (...) as infraestruturas não chegam, mas chega muita gente ${ }^{66 "}$.

Segundo João Silva ${ }^{67}$, há inclusive uma estratégia do poder público de "matar os espaços de encontro", como no caso da Praça do Samba, que é um tradicional ponto de aglomeração de pessoas em Perus. Esse morador avalia que, taticamente, a Subprefeitura instalou unidades de saúde móveis no meio da quadra que há nessa praça, impedindo, fisicamente, uma aglomeração maior de pessoas.

Rodrigo, morador do Recanto dos Humildes - segurança privado e estudante de cursinho pré-vestibular - tem uma visão parecida sobre o cerceamento de espaços de socialização por parte do Estado. Identifica também um confinamento na periferia, por conta da dificuldade de mobilidade. Esse conjunto de ações aponta para um processo de disciplinamento das práticas sociais da população. Mesmo assim, ele nota que surge uma sociabilidade própria da periferia.

Quando eu vim pra cá tinha uma ocupação diferente do espaço público. A praça do samba tinha muito samba lá. Tinha um lugar na frente do Recanto, uma praça, que as pessoas colocavam os carros e colocavam um funk, um sertanejo, um não sei o quê... e as pessoas ficavam lá bebendo se divertindo, era o lazer né?! E aí a policia começou a vir jogar bomba de gás, granada ,e conforme isso começou a acontecer recorrentemente, as pessoas perceberam que não dava pra ir mais, porque toda hora vou tomar gás lacrimogênio na

\footnotetext{
65 Vale ressaltar que além de experienciar filmes coletivamente, realizar reuniões, nesses espaços também ocorriam os bailes do bairro, onde se formavam muitos casais.

${ }^{66}$ Depoimento de Leonardo, ex-morador de Perus.

${ }^{67}$ Morador de Perus e membro da Comunidade Cultural Quilombaque, “organização sem fins lucrativos que surgiu em 2005, a partir da iniciativa de um grupo de jovens, moradores de Perus, bairro periférico (...) que concentra os piores índices socioeconômicos e culturais, onde as maiores vítimas são os jovens". Esse movimento aposta em expressões artísticas e manifestações culturais como uma alternativa de enfrentamento à situação de miséria e violência. Disponível em: < http://comunidadequilombaque.blogspot.com/p/historia.html > . Acessado em 01 de fevereiro de 2016.
} 
cara, uma bomba nas costas, vou me machucar... e decidiram não ir mais e as pessoas começaram a se retrair mais. Conforme essa política de cercamento, de aumentar o preço da passagem, aumentar a condução, não dá pra ir pra Vila Madalena ir numa balada gastar 150 reais, só de passagem ia ser 20, então as pessoas começaram de uns quatro anos pra cá, junto com a onda de imigração, a ter um contexto diferente, porque tinha muita migração nordestina, então tem muito forró, e o forró não é criminalizado que nem o funk, então o que os funkeros começaram a fazer? Começaram a se inserir dentro do forró, então quando você vai no forró, você vê vários estereótipos diferentes, aí você vê um haitiano, perto do funkero, perto do cara dançando forró... nossa que mistura louca! Várias idades, várias etnias, então começa a borbulhar alguma coisa dentro dessa mistura.

Por mais que ainda existam moradores antigos, ex-operários, movimentos sociais e o próprio sindicato buscando resgatar a memória local, a identidade social e cultural construída ao longo século XX, elas estão diluídas nos, agora, vários "bairros". Perus, nos dias de hoje, é mais uma divisão territorial administrativa - que engloba diferentes experiências fragmentadas do espaço metropolitano - do que um bairro. "As famílias mais antigas, todas se conhecem no Recanto. (...) Na minha rua todo mundo se conhece. Falta algo na casa de um, pede no vizinho. É uma grande família”. Essa fala de Laura $^{68}$, moradora do Recanto dos Humildes desde que nasceu, indica que ainda existe uma sociabilidade, típica da periferia metropolitana. No entanto, é notável que essa sociabilidade se realiza de forma fragmentada: não é mais de Perus, é do Recanto, ou ainda mais restrita: é com os vizinhos de rua ou, exclusivamente, entre as "famílias mais antigas" "69 . As condições objetivas do processo de urbanização dificultam a formação de um localismo, tal como ocorreu com os bairros, em um período específico da história urbana. "As periferias que proliferam sobre os escombros da cidade com seus bairros, exigem uma outra perspectiva de entendimento, os raciocínios clássicos sobre a urbanização começam a ficar sem lugar diante dos fenômenos da concentração urbana" (SEABRA, 2010, p. 310).

Apesar de haver um importante esforço de movimentos sociais dentro de Perus pela preservação da memória do bairro, grande parte dos novos moradores não compartilha (e nem conhece) a identidade socioespacial formada no passado desse local. Muitas pessoas mudaram para lá, pois foi o lugar possível de morar na cidade, com pouco ou nenhum vínculo com o local. Atualmente, o distrito de Perus possui quase 150 mil pessoas, o que inviabiliza uma vida comunitária que englobe a todos. Além disso -

\footnotetext{
${ }^{68}$ Laura é agente de saúde.

${ }^{69}$ A moradora se refere aos antigos residentes do Recanto dos Humildes - não de Perus como um todo que tem alguma identificação socioespacial, dentre outros motivos, por compartilhar e por terem compartilhado momentos de construção do novo bairro, como, por exemplo, ao "bater uma lage" ou "abrir uma rua", ações feitas coletivamente, que requerem esforço dos trabalhadores, normalmente aos fins de semana.
} 
exceto pelas pedreiras e pelo comércio - as pessoas tem que sair para trabalhar, caracterizando o local cada vez mais como um bairro "dormitório ${ }^{70 "}$. A identidade de Perus, baseada nas lutas sociais, existe hoje apenas como um resíduo do processo de metropolização. Ainda assim, em algumas situações, ela tem potencial agregador.

\subsection{A reestruturação imobiliária na região noroeste da RMSP}

Apesar dos muitos terrenos livres, os que comportaram o arranque demográfico em Perus foram, em geral, os espaços intersticiais: casas de fundos, beiras de córregos, encostas íngremes, ou um terreno desapropriado pela PMSP. O próprio Recanto dos Humildes avançou sobre dois afluentes do Ribeirão Perus. Além disso, algumas casas grandes unifamiliares localizadas em vilas mais antigas, passaram a ter os cômodos compartimentados, de modo que esses puderam ser vendidos ou alugados para os novos habitantes de Perus, possibilitando uma maior rentabilização da propriedade. Desse modo, a estrutura fundiária (concentrada) apresentou poucas mudanças.

Nesse processo de deslocamento massivo da população para as periferias, evidencia-se o caráter rentista como um dos pilares da metropolização: "a lógica é auferir renda do processo de urbanização por inteiro (...)" (SEABRA, 2003a, p. 105). A mercantilização do espaço se acentua, assim como a disputa por ele. Desse modo, novas demandas sociais são requeridas para o espaço do antigo subúrbio-estação de Perus, de modo que, a imobilidade da propriedade territorial teve que se ajustar às novas necessidades sociais. A compartimentação dos cômodos é um exemplo disso, assim como os chamados "puxadinhos". Essas são formas dos proprietários (especialmente os pequenos) se adequarem às exigências da nova dinâmica da metrópole e poderem obter algum rendimento complementar, tendo em vista que a de propriedade da terra é um meio para captar uma parte da riqueza social produzida ${ }^{71}$.

Romero, professor da rede estadual e proprietário de um lote na Vila Inácio, construiu sua própria casa e mais um sobrado em seu terreno. Para isso, contratou pedreiros, mas também ajudou na obra, aos fins de semana. Segundo ele, a construção

\footnotetext{
${ }^{70}$ Convencionou-se, nos estudos urbanos, nominar "dormitórios" os bairros que são residenciais de trabalhadores que se deslocam para outras regiões onde são empregados. No entanto, a nosso ver, esse termo não expressa bem o fenômeno, pois mesmo passando grande parte do tempo fora do bairro onde moram, as ações e relações dos trabalhadores com esse espaço não se limitam apenas a dormir, há uma série de outras relações que aí ocorrem. Por essa razão, o termo "dormitório" será utilizado sempre entre aspas nessa dissertação.

${ }^{71}$ A tendência de antigos moradores alugarem casas, "puxadinhos", cômodos, também contribui para a não identificação dos moradores com o bairro, pois pessoas chegam e saem dos imóveis com maior frequência, sem criar vínculos com o local e com os vizinhos.
} 
do sobrado para aluguel foi "o melhor investimento da minha vida". Declaração que confirma que o rentismo se configura como uma forma possível de sobrevivência da classe trabalhadora ${ }^{72}$. Romero, inclusive, desejou comprar outro terreno na mesma rua para investir, mas suas economias não foram suficientes.

Diante desse fenômeno se percebe que os espaços na metrópole são cada vez mais preciosos. Para Lefebvre (2008a, p. 125) o espaço - assim como outros elementos naturais - se tornou uma "nova raridade". Não em um sentido absoluto, como se o espaço estivesse acabando, mas, sim, em um sentido relativo: o espaço em torno das grandes centralidades está se tornando cada vez menos disponível. Portanto, cria-se socialmente uma raridade do espaço, pelo desenrolar cego da racionalidade econômica, que torna a permanência em um local nos centros urbanos cada vez mais disputada e cara.

O espaço urbano tornado raro, associado à ampla demanda de pessoas necessitando de se posicionar próximas à centralidade urbana, leva à produção e mercantilização dessa nova raridade, tornando-se um lucrativo negócio. “(...) O espaço é artificialmente rarefeito para "valer" mais caro; ele é fragmentado, pulverizado, para a venda no atacado e no varejo. Ele é o meio de segregações" (Ibid., p. 125).

O processo de metropolização fez com que o núcleo isolado de Perus fosse forçado a adentrar no núcleo de urbanização contínua. A ponta de lança desse movimento de conurbação foi a classe trabalhadora mais pobre, desde fins dos anos sessenta, como já relatado. A partir do final dos anos oitenta, esse processo se tornou massivo com intensificação da favelização. Contraditoriamente, um lugar com abundância de terras livres assistia de perto a raridade do espaço se forjar, através da racionalidade econômica dos grandes proprietários, que delimitavam as áreas de expansão que comprimiam os espaços ocupáveis ${ }^{73}$.

Após a desconcentração industrial, o caráter rentista do espaço urbano se acentuou. É possível afirmar que a construção do Rodoanel é um ponto de ruptura para a dinâmica imobiliária da região noroeste, visto que a criação dessa estrutura agrega valor ao espaço de entorno e abre uma série de especulações sobre o uso dos terrenos, atraindo mais investidores para a região. Essa estrutura integra um processo mais

\footnotetext{
72 A difusão do padrão periférico de urbanização, através dos loteamentos afastados do centro, gerou, nas grandes cidades brasileiras, uma não autonomização completa entre as categorias terra e trabalho. Isso permitiu que parte dos trabalhadores conjugassem suas atividades assalariadas com formas de rentismo.

${ }^{73}$ A necessidade de moradia era tão grande que a própria área do Aterro Sanitário foi ocupada algumas vezes, sendo reintegrada a posse em seguida.
} 
amplo, sendo suporte da circulação geral de mercadorias na metrópole, mas sem deixar de ser um produto particular que afeta a dinâmica local. A partir dela, desencadeia-se, assim, um processo de valorização imobiliária, a partir do que Harvey denominou de “corrente de capital" (1990, p. 370). A mudança na dinâmica espacial de Perus, que se iniciou com a "periferização", transforma-se de novo, a partir da reestruturação imobiliária proposta pelo Rodoanel. O cinturão de negócios imobiliários na metrópole é ampliado em sua escala espacial: "Estratégias que se expandem, também, por outros eixos de valorização, o que nos leva ao Rodoanel, como a fronteira desenhada dos novos negócios potenciais da urbanização" (DAMIANI, 2008, p. 245). Esse fenômeno, combinado com a desconcentração industrial, é elemento das transformações nos usos dos espaços da cidade:

Desde a crise dos anos 1980, um conjunto de antigas áreas industriais, desativadas (...) prenunciavam a obsolescência de parte do capital fixo da metrópole e, ao mesmo tempo, as potencialidades abertas pela localização relativa dessas propriedades e pela sua dimensão fundiária, em meio a uma intensa fragmentação (ALVAREZ, 2014, p. 290).

Extensas propriedades fundiárias, tão raras na área contígua de urbanização, existiam (e existem) em abundância na região noroeste da RMSP. Antes afastadas, essas terras são ressignificadas pelo Rodoanel, que inaugura uma nova situação geográfica nessa porção da metrópole, pois interliga a região com todas as principais rodovias de São Paulo. A contingência curiosa da região noroeste de ser, ao mesmo tempo, o começo do Rodoanel (trecho oeste foi inaugurado em 2003) e o fim (trecho norte está previsto para 2019) faz com que esse lugar seja palco simultâneo de valorização e de especulação imobiliária, dado o compasso de espera para a conclusão da autoestrada.

A reestruturação imobiliária, induzida por essa política espacial, faz-se notável a partir dos movimentos dos grandes proprietários da região. O sentido último da ação dessa classe social é extrair o máximo possível de renda fundiária, capturando, assim, a maior fração da mais-valia produzida socialmente. Aparentemente, os espaços que vêm sendo produzidos nessa região, que melhor cumprem essa função, são centros logísticos e os condomínios residenciais.

A Cia. Melhoramentos, que dispõe de um enorme banco de terras na região é, sem dúvida, a instituição envolvida nos maiores e mais diversos projetos imobiliários. Seu estoque fundiário está, aos poucos, fragmentando-se através de vendas de grandes glebas, loteamentos, arrendamentos e, também, da produção de imóveis. Vejamos alguns exemplos, a fim de compreender o processo. 
Essa empresa vendeu, em 2007, para Camargo Correa Desenvolvimento Imobiliário S.A. (CCDI), um terreno localizado no sul do município de Caieiras (ver Mapa 2), com área de 5,2 milhões de metros quadrados, pelo valor inicial de R\$ 28 milhões, ao qual seria acrescido mais um valor referente ao lucro do projeto imobiliário que viria a ser implantado. Segundo a CCDI, o Valor Geral de Vendas estimado para o futuro empreendimento é da ordem de $\mathrm{R} \$ 2,5$ a 3 bilhões, sendo uma porcentagem destinada para a Cia. Melhoramentos. A ideia seria produzir uma "nova cidade", com cerca de 20.000 unidades habitacionais ${ }^{74}$, abrigando 80.000 pessoas, basicamente dobrando a população atual de Caieiras. As pretensões imobiliárias da CCDI na região pareciam não parar por aí:

Com isso, estarão criadas condições para a instalação, na região, de unidades comerciais (shopping centers, centros comerciais e lojas de rua), industriais e de apoio (educacionais, hospitalares e de serviços), alterando, de maneira sustentável ${ }^{75}$, a vocação da região ${ }^{76}$.

Esse trecho, extraído do documento emitido pela própria CCDI para seus investidores, indica a estratégia da indústria imobiliária de criar condições para si mesma de ter mais frentes de negócios com a produção da cidade. Trata-se de uma tentativa de se criar novas centralidades, que, por sua vez, desdobrar-se-ão em necessidades distintas e, consequentemente, novos produtos imobiliários. A citação representa como seria o desenrolar ideal da reestruturação espacial ${ }^{77}$. No entanto, até os dias de hoje, nenhuma obra foi feita nesse grande terreno, que permanece sem uso.

Nesse sentido, podemos afirmar que a nova centralidade da região noroeste, em parte, ainda se configura como uma especulação, por mais que haja indícios de que ela já é uma realidade. As grandes negociatas da Melhoramentos, no entanto, ainda estão no

\footnotetext{
${ }^{74}$ Tanto em prédios de quatro andares, quanto em lotes horizontais, além de espaço para apoio comercial. As unidades teriam entre 60 e $120 \mathrm{~m}^{2}$ e seriam comercializadas de $\mathrm{R} \$ 70$ a 200 mil cada. Todas informações sobre essa transação e esse projeto estão disponíveis no endereço: < http://www.espiral.fau.usp.br/arquivos-BD-NW/Caieiras/2007-Camargo_caieiras.pdf >. Acessado em 24 de julho de 2018.

${ }^{75}$ Destaque para o uso de "sustentável" como uma palavra vazia. Em nenhum momento no documento esse termo é justificado, de modo que não é possível decifrar em qual sentido está sendo empregado. Esse tema será abordado no capítulo 2.

76 Divulgação de aquisição da empresa para os acionistas, 2007. (disponível em < http://www.espiral.fau.usp.br/arquivos-BD-NW/Caieiras/2007-Camargo_caieiras.pdf >. Acessado em 13 de maio de 2014).

${ }^{77} \mathrm{Na}$ atual dinâmica de produção do espaço, há uma tendência de locais que concentram a maioria dos investimentos imobiliários dentro das cidades. Exatamente por esse fato, esses locais são os que promovem melhores oportunidades de retorno para outras inversões de capital imobiliário, conformando, assim, um processo de autoalimentação da riqueza que atrai, gerando mais riqueza. Fato que culmina na centralização geográfica do capital em fragmentos específicos da metrópole. Harvey (1990) cunhou como "corrente de capital" um processo semelhante a esse. Na metrópole de São Paulo, um exemplo desse tipo de espaço é a região sudoeste. Há uma tentativa de se criar "novas centralidades" para o capital financeiro imobiliário poder se reproduzir. Para que isso ocorra, a intervenção do Estado se faz essencial, criando novos eixos de valorização. O Rodoanel representa um desses possíveis eixos.
} 
nível das apostas sobre o espaço. Desde 2011, um terreno de 12,770 milhões de metros quadrados, localizado entre Caieiras e Cajamar (ver Mapa $2^{78}$ ), vem sendo negociado entre a Melhoramentos e CCR S.A. ${ }^{79}$. Em 2016, a compra se consumou pelo valor total de R\$ 387,415 milhões ${ }^{80}$. A Space Empreendimentos Imobiliários Ltda., empresa de propriedade do grupo Melhoramentos, foi quem efetivou a transação. Segundo a CCR, no terreno localizado entre as Rodovias Anhanguera e Bandeirantes ${ }^{81}$ deve ser instalado o Novo Aeroporto de São Paulo (Nasp), que seria totalmente privado, receberia aviões de todos os portes e teria capacidade para tráfego de 40 a 50 milhões de passageiros por ano. O empreendimento ainda aguarda aprovação do Governo Federal ${ }^{82}$.

Sem dúvida, a inserção de um aeroporto na região causaria uma redefinição da situação geográfica da região em outra escala. Esse capital fixo, fixado à terra, resultaria em um notável incremento na corrente de capital dessa possível nova centralidade. Contudo, o terreno persiste sem qualquer uso.

Outro grande projeto que envolve as terras da Cia. Melhoramentos é o Novo Entreposto de São Paulo (Nesp). A sonoridade semelhante dos novos empreendimentos (Nesp e Nasp) sugere um projeto coordenado pela reestruturação da cidade como um todo. A ênfase no termo "novo", de certa forma, leva a crer que outras estruturas urbanas já são "velhas", obsoletas e, parece querer nos induzir a acreditar que esse espaço será uma nova centralidade. O próprio projeto do Nesp afirma que se busca "requalificar uma região carente ${ }^{83} "$.

O Nesp S.A. ${ }^{84}$ propõe um empreendimento que ficou conhecido popularmente como "novo Ceagesp". Trata-se de um projeto de criação de um polo logístico ${ }^{85}$. Mais

\footnotetext{
${ }^{78}$ Não foi encontrada nenhuma delimitação precisa dos limites do terreno do Nasp. Assim, o realizou-se um mapeamento aproximado da área a partir da metragem divulgada na mídia e de informações secundárias.

${ }^{79}$ A Companhia de Concessões Rodoviárias S.A. atua na área de produção de infraestrutura e transporte. Os principais acionistas dessa empresa são o Grupo Andrade Gutierrez, Grupo Camargo Corrêa e o Grupo Soares Penido.

${ }^{80}$ CCR fecha compra em Caieiras e Cajamar para aeroporto. EXAME. São Paulo, mar. 2016. Disponível em: < https://exame.abril.com.br/negocios/ccr-fecha-compra-em-caieiras-e-cajamar-para-aeroporto/ >. Acessado em 21 de julho de 2017.

${ }^{81}$ Rodovias administradas pela CCR.

${ }^{82}$ Construtoras dizem que novo aeroporto de São Paulo poderia começar a operar em 2020. O Estado de São Paulo, São Paulo, mar. 2014. Disponível em: < https://economia.estadao.com.br/noticias/geral,construtoras-dizem-que-novo-aeroporto-de-sp-poderiacomecar-a-operar-em-2020-imp-,1137719 > . Acessado em 21 de agosto de 2017.

${ }^{83}$ ESTUDOS TÉCNICOS PIU NESP RELATÓRIO FINAL, 2016, São Paulo. São Paulo: Prefeitura de São Paulo, 2016. Disponível em:< http://minuta.gestaourbana.prefeitura.sp.gov.br/decreto-piu-nesp/wpcontent/uploads/2016/11/PIU_NESP_Relatorio_Final_161116_00.pdf >. Acessado 21 de junho de 2018.

${ }^{84}$ Empresa inicialmente formada por empresários do setor do abastecimento.
} 
especificamente, uma rede logística de abastecimento de alimentos. O empreendimento deve ocupar um terreno de aproximadamente 4 milhões de metros quadrados na parte norte e oeste do distrito de Perus, nos dois lados da Rodovia dos Bandeirantes, chegando até a fronteira com Caieiras, de modo a ocupar praticamente todas as terras sem uso do norte do distrito (ver mapas 2,3 e 7$)^{86}$. Trata-se de um empreendimento totalmente privado ${ }^{87}$, que, no entanto, contou com grande apoio da $\mathrm{PMSP}^{88}$ que não mediu esforços para alterar o zoneamento da área de forma compatível com a proposta do Nesp ${ }^{89}$. Inclusive, a viabilização desse empreendimento se valeu de um novo instrumento jurídico que é o PIU (Proposta de Intervenção Urbanística), algo que merece maior atenção em futuras pesquisas, pois se trata de um novo mecanismo de flexibilização do planejamento e de expansão dos negócios imobiliários em associação com o Estado.

As informações sobre a negociação do terreno não foram bem divulgadas, mas, aparentemente, o Nesp adquiriu somente um pedaço de todas as terras que pretende ocupar, por enquanto. Segundo o jornal $O$ Estado de São Paulo, o espaço adquirido foi de 1,4 milhão de metros quadrados ${ }^{90}$, comprado através do capital arrecadado com a venda de ações que correspondem à propriedade do lote e a uma cota da empresa que vai gerir o entreposto. Para a realização do restante do projeto o Nesp espera contar com financiamento do BNDES (Banco Nacional de Desenvolvimento Econômico e Social) e de fundos de investimentos. A inauguração da primeira fase do empreendimento está

85 "Atividade de transporte, armazenagem, rastreamento e informações acerca de um objeto ou carga desde a recepção até a entrega final ao cliente" (SALGADO et al., 2012, p. 27), assim é a definição do conceito de logística que o próprio Plano de Bairro de Perus apresenta.

${ }^{86} \mathrm{O}$ Nesp seria a primeira etapa de um projeto maior o Padesp (Polo de Abastecimento, Distribuição e Entreposto de São Paulo). A segunda etapa do Padesp seria realizada em um grande terreno à oeste do distrito de Anhanguera (Mapa 2). A área total (duas fases) seria de 6,3 milhões de metros quadrados.

${ }^{87} \mathrm{O}$ projeto pode se transformar em uma parceria público-privada, caso vença a concorrência aberta para sediar o novo Ceagesp, que está sob análise do Governo Federal. O antigo, na Vila Leopoldina, deve ser desinstalado nos próximos anos. O Nesp disputa com outros três projetos, todos posicionados em áreas próximas ao Rodoanel. Os empresários do Nesp afirmam que mesmo que esse projeto não seja escolhido pelo Estado, o empreendimento será realizado, como um entreposto privado.

${ }^{88}$ A desativação do Ceagesp na região da Vila Leopoldina, assim como sua instalação em Perus, também faz parte do processo de reestruturação imobiliária, visto que essa antiga área industrial da zona oeste está sendo convertida para outros usos.

${ }^{89}$ O Nesp está projetado sobre uma ZOE (Zona de Ocupação Especial). Segundo a lei no 16.402/2016, esse tipo de zona corresponde a: "Porções do território destinadas a abrigar atividades que, por suas características únicas, necessitem disciplina especial de uso e ocupação do solo". Anteriormente à nova lei de zoneamento de 2016, essa área era tipificada como uma ZEPAG (Zona Especial de Produção Agrícola e de Extração Mineral). A mudança de um zoneamento agrícola para uma zona de investimentos especiais indica bem o processo de reestruturação imobiliária.

${ }^{90}$ Projeto da 'nova Ceagesp' tem hotel e centro comercial; inauguração deve ser em 2021. O Estado de São Paulo, São Paulo, mai. 2017. Disponível em: < https://saopaulo.estadao.com.br/noticias/geral,projeto-da-nova-ceagesp-tem-hotel-e-centro-comercial-inauguracaodeve-ser-em-2021,70001812223 > Acessado em 15 de dezembro de 2017. 
prevista para 2021. Entretanto, apesar de estarem em andamento os processos de licenciamento, o terreno continua sem uso, até o presente momento ${ }^{91}$.

O urbanista Carlos, encarregado pelo Nesp para a elaboração do projeto urbanístico desse empreendimento, afirmou durante a Audiência Pública de apresentação do projeto à população de Perus, que essa região seria "a última fronteira urbana" da cidade de São Paulo. Essa expressão - repetida também por vereadores presentes - reitera a ideia de raridade do espaço. Os espaços que "sobraram" passam a ser alvos de interesses e especulações diversas, devido ao capital fictício que essas propriedades representam e, ainda, aos que elas podem mobilizar. Nesse sentido, fica claro que a região noroeste é uma área visada para os negócios de expansão da cidade.

A efetiva realização do Nesp seria a definitiva consumação de um processo de redefinição da situação geográfica e da reestruturação imobiliária em Perus: um bairro operário, transformado em uma periferia “dormitório" e que se converteria em um polo logístico nacional.

Na verdade, a questão logística já é uma realidade na região noroeste da RMSP. Ainda em menor grau, nas áreas lindeiras à Rodovia dos Bandeirantes ${ }^{92}$. Mas na Rodovia Anhanguera é possível observar uma concentração de galpões e centros logísticos. Alguns poucos localizados no distrito de Anhanguera - local onde há muitas especulações, devido à quantidade de terras desocupadas. No município de Cajamar área de enorme concentração fundiária da família Abdalla - é possível observar um verdadeiro aglomerado de galpões de tamanhos diversos, além de canteiros de obras de futuros galpões logísticos. Aí sim está configurado um polo logístico. É impressionante notar a velocidade da transformação espacial nos bairros de Gato Preto e Jordanésia entre os anos 2008 e 2018, como é possível notar nas figuras 2 e 3. Grandes empresas nacionais e transnacionais têm galpões instalados nessa área da metrópole ${ }^{93}$.

\footnotetext{
${ }^{91}$ A partir de 2015, houve uma pequena expansão da ocupação de favela para a área onde está planejado o Nesp. Se o projeto realmente vingar, provavelmente haverá alguma disputa referente a essa área.

92 Para a realização do Nesp seria necessária a construção de uma nova saída da Rodovia dos Bandeirantes para o bairro de Perus, o que vem sendo negociado entre os empresários e o poder público. A construção desse acesso do norte do distrito à rodovia Bandeirantes seria benéfica também para a família Abdalla, pois traria maior acessibilidade à parte norte do distrito, onde se pretende construir uma série de condomínios.

${ }^{93}$ É possível desdobrar uma discussão sobre a reestruturação produtiva partindo da superação do modelo fordista de organização da produção, de grandes plantas industriais, grandes estoques etc., para um modelo assentado sobre uma produção flexível, baseada no sistema just in time, onde os estoques necessários ao processo produtivo e comercial são supridos no tempo certo e na quantidade exata. Nessa reestruturação organizacional da produção, ganha importância a logística (e os seus galpões), assim como as áreas bem situadas em relação aos meios de transporte e ao mercado consumidor. Para mais
} 
Diferentemente de outras áreas da metrópole que estão vivenciando a reestruturação imobiliária, a região noroeste apresenta maior facilidade de converter os usos, graças ao controle do espaço realizado no passado, que garantiu muitos terrenos vagos. Isso é interessante - do ponto de vista da reprodução do espaço -, pois há menos conflitos sociais, que seriam causados caso fosse necessária uma "destruição criativa" (HARVEY, 2011), que acarreta a demolição dos antigos imóveis que, em sua estrutura ou tamanho, já não comportam as novas necessidades do capital. A “destruição criativa” acaba sendo um processo mais conflituoso e traumático, pois envolve remoções e desmantelamento dos usos pretéritos do espaço. Nesses momentos, o capital expõe toda sua desumanidade e truculência. Exemplos recentes desse tipo de expropriação, via “destruição criativa”, são inúmeros no Brasil e no mundo. Não são casos isolados, há uma lógica de mobilização da propriedade a serviço da

\section{(...) reprodução do espaço orientada pela lógica do capital financeiro, transformando o uso e o sentido dos lugares, sobretudo a partir da remoção de dezenas de milhares de famílias, em áreas que sofrem por projetos disparados e mediados pelo poder público, mas sempre em parceria com o setor privado (ALVAREZ, 2014, p. 274).}

Por mais que o noroeste da RMSP seja privilegiado nesse sentido para o capital, esses tipos de enfretamento desiguais também acontecem por lá. Nessa mesma área de Cajamar, onde foram construídos rapidamente esses vários galpões logísticos, houve um exemplo de remoção, cujo processo foi obscuro e antidemocrático. O Gato Preto - onde estão localizadas as pedreiras de calcário da antiga CBCPP - bairro operário que participou das greves dos Queixadas, teve parte de suas antigas casas demolidas, sob argumentação de estarem em uma área de risco. No entanto, é no mínimo questionável que uma área de ocupação tão antiga esteja em área de risco agora, justamente quando ela está na rota de expansão dos galpões logísticos (ver figuras 4 e 5). Além disso, construções tombadas pelo patrimônio histórico, como fornos de cal, também foram demolidas sem explicação ${ }^{94}$.

informações sobre essa mudança de estratégia de acumulação do capital, ver Botelho (2000) ou Harvey (2014).

${ }^{94}$ Para mais informações sobre esse processo de remoção, assistir documentário "O sepulcro do Gato Preto" (2016), dos diretores Frederico Moreira e Kaneda Asfixia. Disponível em: < https://www.youtube.com/watch?v=74ehcYWe4oU >. Acessado em 30 de abril de 2017. 
Figuras 2 e 3 - Imagens de satélite da área do Centro Logístico de Cajamar em 2008 (cima) e 2018 (baixo)
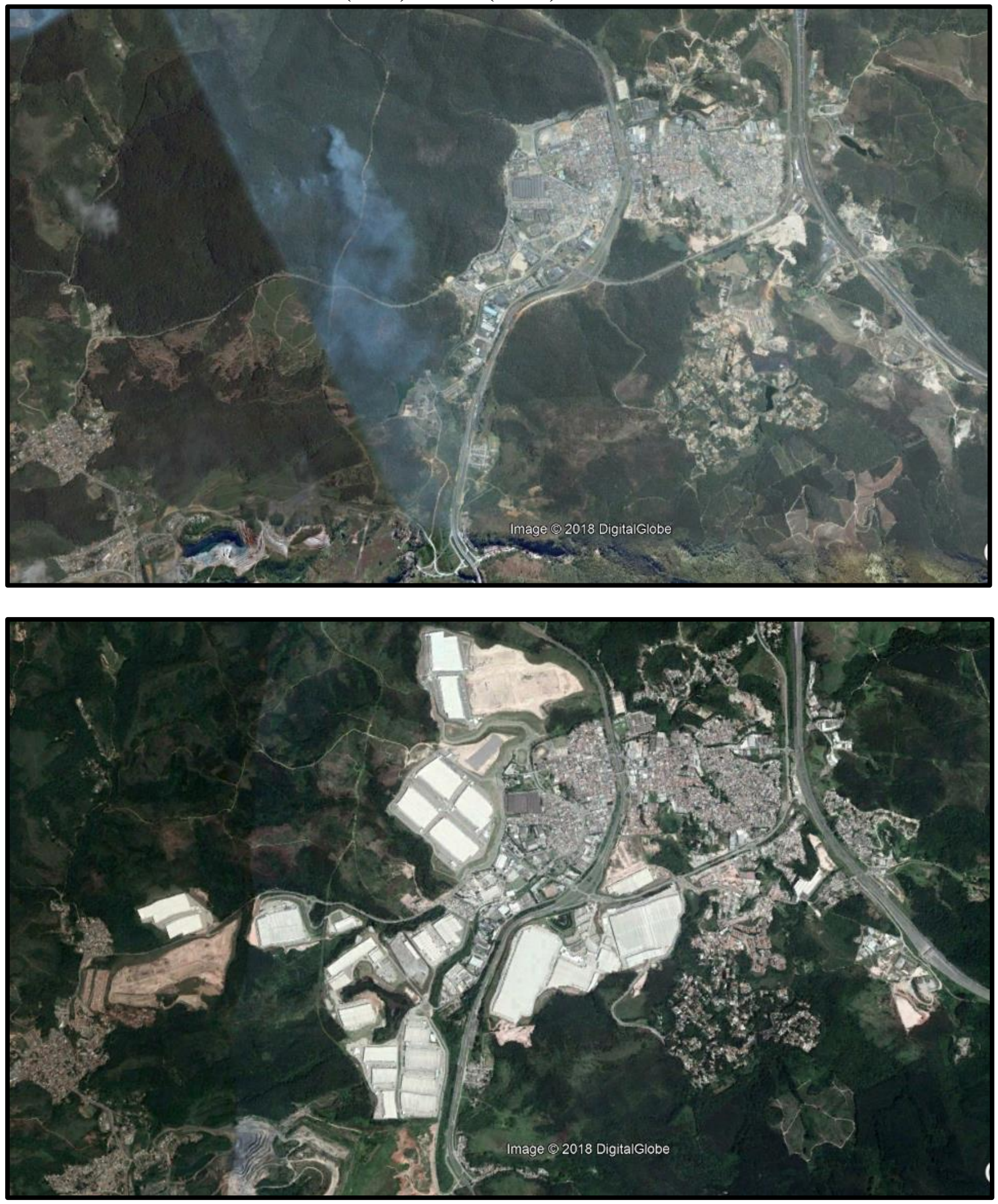

Fonte: Google Earth Transformação de espaço rural em galpões logísticos no município de Cajamar. 
Figuras 4 e 5 - Imagens de satélite de área do bairro do Gato Preto, em 2008 (cima), antes da remoção e, em 2017 (baixo), depois da remoção.
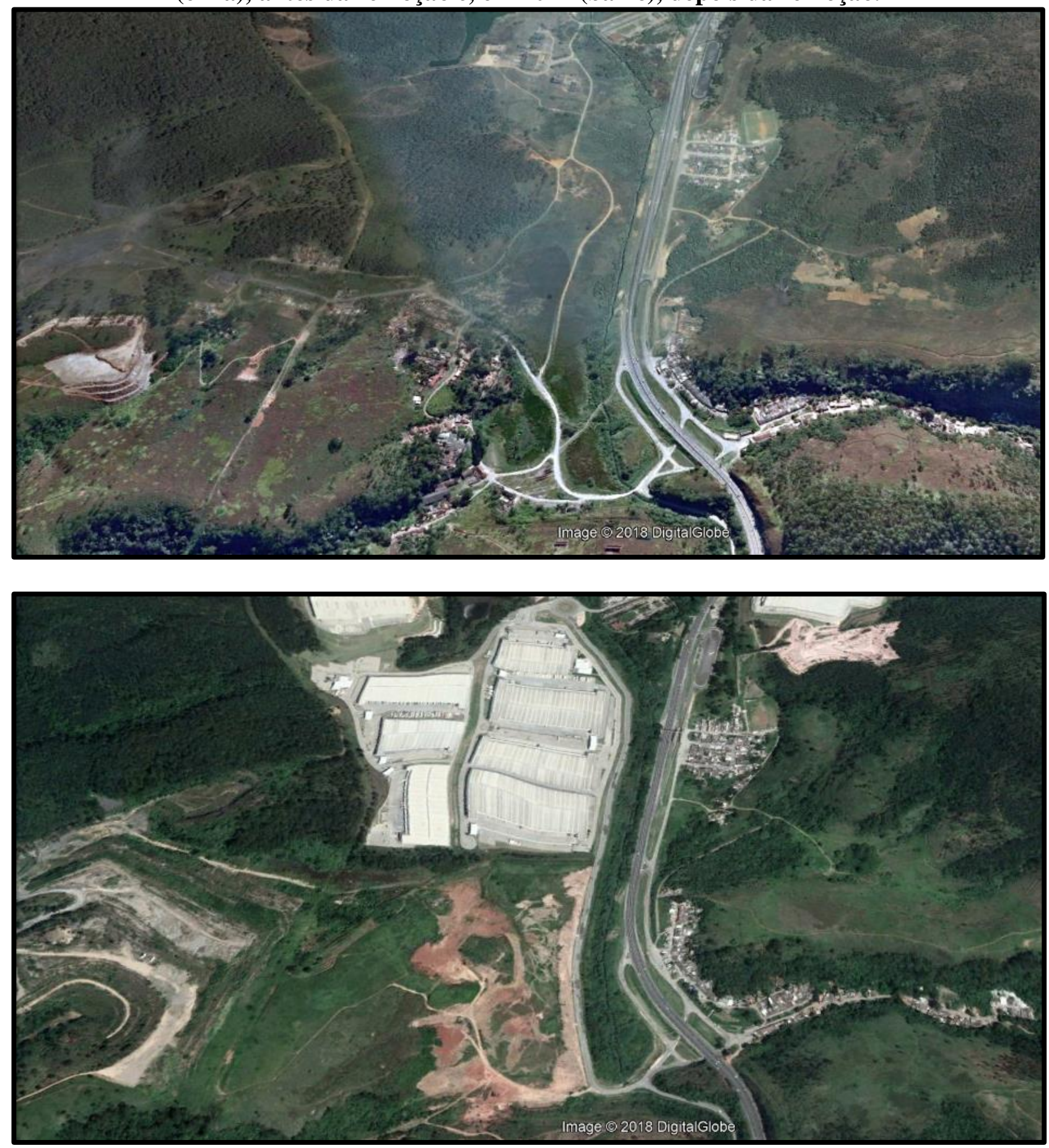

Fonte: Google Earth O aglomerado de casas, visível na parte de baixo da imagem de 2008, aparece na, imagem de 2017, destruído. Concomitantemente, observa-se o avanço da construção de galpões logísticos em direção à área desse núcleo removido. O bairro do Gato Preto formou-se para ser moradia dos operários das minas da CBCPP. À esquerda das imagens é possível ver o início das áreas de extração de calcário, que eram da CBCPP, e hoje são propriedades da Votorantim.

Não há como dissociar a voracidade do capital imobiliário de sua relação com o capital financeiro. Diante da crise nos anos setenta, ocorreu uma migração massiva dos capitais produtivos para o mercado financeiro de ações. A partir dos anos noventa se 
observa a migração de capitais do mercado de ações (já inchado) para o mercado financeiro imobiliário, cujo lastro são as terras e os negócios a elas associados. Nesse caso o objeto da especulação financeira não são apenas os papéis, mas também as construções (KURZ, 2005).

Podemos observar que esse movimento de financeirização do setor imobiliário aparece na metrópole de São Paulo através de distintas formas de aplicação de capital, como por exemplo, por meio de Fundos de Investimentos Imobiliários (FII $)^{95}$ ou empresas imobiliárias - nacionais e transnacionais - de capital aberto, dentre outras diversas formas.

No referido centro logístico de Cajamar está em construção um galpão logístico da Global Logistic Proprieties (GLP), sediada em Singapura, maior empresa de instalações logísticas do mundo e que também atua como gestora de vários fundos de investimentos imobiliários em distintos países ${ }^{96}$. A GLP, portanto, é, ao mesmo tempo, exemplo das duas formas de aplicação de capital financeiro no setor imobiliário aqui exemplificadas. Ambas estão presentes em Cajamar, por meio dessa empresa: o fundo GLP Brazil Development Partners I comprou o terreno e financiará a construção do imóvel e é a própria GLP que vai gerenciar o galpão.

“Ainda não estávamos presentes no mercado de Cajamar, que é bastante consolidado e tem baixa vacância", disse o presidente da GLP, Mauro Dias, ao jornal Valor $^{97}$. A baixa vacância e a quantidade de galpões novos sendo produzidos em Cajamar indicam que a situação geográfica dessa área - próxima do mercado consumidor da RMSP, do Rodoanel, Bandeirantes e Anhanguera - deve estar auferindo rendimentos fundiários excepcionais.

A atuação da empresa GLP evidencia que para a ocorrência de rendimentos excepcionais as grandes empresas imobiliárias dependem de uma atuação do Estado, no sentido de promover um situação geográfica diferenciada, que oportuniza aumento esse aumento nos lucros:

\footnotetext{
${ }^{95}$ Esses fundos permitem que investidores de distintos portes unam seus capitais a ponto de criar a liquidez necessária para a inversão em grandes investimentos imobiliários, tais quais modernos edifícios corporativos, shoppings centers, centros de logística, hospitais, unidades habitacionais de alto padrão, entre outros. Evidentemente cada um desses produtos imobiliários significa um nível de rentabilidade distinto.

${ }^{96}$ A GLP gerencia mais de US\$ 46 bilhões de ativos imobiliários com um portfólio global de 62 milhões de metros quadrados. Disponível em: < http://glprop.com.br >. Acessado em 02 de julho de 2018.

${ }^{97}$ GLP compra terreno em Cajamar para desenvolver dois galpões. Valor, São Paulo, abril/2015. Disponível em: < https://www.valor.com.br/empresas/4003226/glp-compra-terreno-em-cajamar-paradesenvolver-dois-galpoes >. Acessado em 14 de abril de 2018.
} 
A estruturação dessa frente de expansão logística ao longo do Rodoanel com a entrada de agentes globais torna-se ainda mais clara quando tomamos como exemplo a vinda da especializada em logística GLP para o Brasil em 2012, coincidindo com o início das obras dos trechos Leste, no final de 2011, e Norte, no início de 2013. Para além disso, em 2014, a GLP comprou um grande pacote de propriedades logísticas da BR Properties, no movimento de baixa dos preços devido à crise econômica, muitas das quais estão localizadas nas proximidades do Rodoanel (ROLNIK e SANTORO, 2017, p. 425).

O papel do Estado neoliberal, de criar condições para a reprodução do capital imobiliário, também se revela pelo fato de os primeiros centros logísticos da região noroeste terem iniciado sua construção em 1998, mesmo ano que as obras do Rodoanel Oeste. Esse é o caso dos galpões da Yusen Logistics (empresa japonesa) e da FM Logistic (empresa francesa), ambas localizadas no distrito de Anhanguera ${ }^{98}$. Essa simultaneidade não é coincidência e evidencia o Rodoanel como um novo eixo para expansão dos negócios financeiro-imobiliários ${ }^{99}$.

Não se pretende aqui desenvolver uma longa discussão em torno da ideia de financeirização. Busca-se trabalhar a partir do fato de que o capital financeiro está profundamente imbricado na produção do espaço, de modo que os níveis de rentabilidade de uma ação de uma empresa ou de uma cota de um fundo imobiliário dependem de uma produção crescente de novos espaços. Isso gera consequências socioespaciais. Por exemplo, a necessidade constante de se mobilizar terrenos - livres ou não - para a aplicação desses capitais. Damiani observa que, para a reprodução desse capital financeiro, uma quantidade enorme de terras tem que ser mobilizada, de distintos modos, sendo assim possível estabelecer uma relação com o processo de acumulação primitiva de capital, descrito por Marx como processo de gênese do capitalismo (MARX, 1985):

\footnotetext{
À absorção de terras de domínio público, ao saque de terras comunais, ao roubo das posses de terra camponesas, como partes da acumulação originária e pressuposto do capitalismo, soma-se a acumulação por despossessão, reposta estruturalmente, pela economia política do espaço, como condição de existência do capitalismo, sua reprodução. Reprodução crítica, pois a valorização do valor, implicada na produção do espaço, inclui um movimento de financeirização tão voraz que pode equivaler à desvalorização, deterioração ou destruição do novo valor produzido. Nestes termos, é possível problematizar a acumulação primitiva do espaço, no âmbito da reprodução ampliada do capital (DAMIANI, 2016, p. 31-32).
}

\footnotetext{
${ }^{98}$ Rolnik e Santoro chegam a conclusão semelhante “(...) ficou clara uma enorme sincronização entre a ação do Poder Público, que, por meio de uma Parceria Público-Privada, deu início às obras do Rodoanel, e a construção dos galpões" (2017, p. 424-425).

${ }^{99}$ Um outro exemplo de empresa que instalou um centro logístico nas antigas terras da família Abdalla foi a Hines, corporação estadunidense de capital aberto, que atua em diversos ramos do setor imobiliário.
} 
No sentido específico do risco de remoções de casas por conta da criação de centros logísticos ao longo do Rodoanel, Rolnik e Santoro, analisando dados dos FII, afirmam:

Como em todo processo de valorização de terras que ocorre a partir da criação de uma nova frente de expansão imobiliária, a tendência é que se acentuem, ao longo dessa frente, a segregação socioterritorial e as remoções. Cruzando a ação dos fundos logísticos com o mapa disponibilizado pela plataforma do Observatório de Remoções de 2016, é possível observar que, ainda que se trate de um vetor incipiente, já há uma concentração de ameaças nas proximidades do Rodoanel (ROLNIK e SANTORO, 2017, p. 425).

Podemos interpretar que a velocidade impressionante com que foi erguido o polo logístico de Cajamar e a truculência na remoção das casas do Gato Preto se justificam pelo tempo acelerado de retorno que os capitais financeiros exigem e também pela necessidade desse tipo de capital de incorporar terras que possam auferir boas rendas ${ }^{100}$.

Outro impacto da financeirização do setor imobiliário é a estratégia de se buscar remunerar o capital financeiro - nas taxas e na velocidade comum a esse mercado através da superexploração do trabalhador do canteiro de obras. Em 2013, por exemplo, as construtoras responderam por dois terços dos flagrantes de trabalhadores em situações análogas à escravidão no Brasil, segundo o Ministério do Trabalho. Boa parte das construtoras autuadas são empresas de capital aberto, como a OAS e a MRV ${ }^{101}$. Portanto, a acumulação primitiva do espaço e a superexploração do trabalho são outras faces que garantem a remuneração dos investimentos financeiro-imobiliários.

Cientes dessas determinações de nosso tempo, retomemos a análise sobre as atividades imobiliárias e especulativas em torno das grandes propriedades da região noroeste. No terreno da antiga CBCPP, o fato do prédio da fábrica de cimento ter sido tombado pelo Compresp dificultou a viabilização de grandes projetos nesse terreno. E, também, a militância dos moradores de Perus pela utilização social da fábrica, é obstáculo para grandes manobras imobiliárias. Os proprietários já tentaram reverter o tombamento, sem sucesso, e, atualmente, o local está em pleno processo de degradação ${ }^{102}$. Recentemente, em outra área desse mesmo terreno, buscou-se viabilizar

\footnotetext{
100 "Os FIIs e CRIs [Certificado de Recebíveis Imobiliários] são ativos financeiros que se valorizam através não só da produção imobiliária, mas também, e em grande medida, da localização do imóvel no tecido urbano. Dessa forma, a renda fundiária faria parte dos rendimentos pagos aos investidores, na medida em que tais rendimentos teriam uma relação direta com o lugar ocupado pelo imóvel no urbano" (BOTELHO, 2008, p.33).

${ }_{101}$ Construtoras respondem por $66 \%$ dos maiores flagrantes de trabalho escravo do ano. O Globo, Rio de Janeiro, dez. 2013. Disponível em: < https://oglobo.globo.com/economia/construtoras-respondem-por-66dos-maiores-flagrantes-de-trabalho-escravo-do-ano-11004548 >. Acessado em 25/06/2015.

${ }^{102}$ Os moradores locais se queixam que aos finais de semana, o prédio costuma ser alugado e usado para a prática de paintball, com anuência do Compresp que autoriza essa prática "esportiva e cultural". Os
} 
um projeto imobiliário de um condomínio residencial. Segundo informações relatadas na audiência pública ${ }^{103}$ sobre o tema, seriam prédios de 5 a 17 andares, que abrigariam aproximadamente 5000 novas unidades habitacionais, financiadas pelo programa Minha Casa Minha Vida ${ }^{104}$. Houve divergência na audiência sobre se o bairro estaria preparado para tamanho crescimento populacional. Aparentemente, esse projeto não vingou, por enquanto. No capítulo 3, debater-se-á mais sobre os possíveis usos da fábrica de cimento.

A família Peccicacco também está se valendo de seus terrenos para construir novos produtos imobiliários. Um terreno de 45 mil metros quadrados - que fora a casa da família durante anos - foi vendido e nele estão sendo produzidos dois condomínios residenciais que totalizarão seis prédios, com apartamentos de 40 metros quadrados, além de espaços de lazer como quadra, piscina, churrasqueira, academia, etc. $\mathrm{O}$ empreendimento, realizado pela Atua Econ Construtora, contará também com um novo centro comercial no mesmo terreno. O empreendimento faz parte do programa Minha Casa Minha Vida, faixa 3, destinado para famílias com renda bruta mensal acima de R \$ 3.600,00 e até $\mathrm{R} \$ 6.500$. As quatro primeiras torres já estão em fase de acabamento. As duas últimas começarão a ser construídas em breve. Seu preço de venda, na planta, está estipulado em R\$ 199 mil.

Os planos da família Peccicacco de desfrutar do potencial imobiliário da região não param por aí, em nota emitida para o Jornal Primeira Impressão (de Caieiras), eles afirmam: "A ideia da Família Peccicacco é criar uma nova cidade dentro do bairro de Perus ${ }^{105}$ ", referindo-se a outras propriedades no bairro. Os terrenos da família estão ao redor da junção do Rodoanel Oeste e Norte, possivelmente, por isso, há uma espera maior para novos negócios, já que o do trecho norte não foi finalizado.

movimentos sociais que lutam pelo uso da fábrica como meio de desenvolvimento cultural não são autorizados a usar esse espaço e reclamam da seletividade imposta pelo órgão municipal. Disponível em: https://movimentofabricaperus.wordpress.com/2016/02/03/audiencia-publica-discute-impacto-de-projetohabitacional-nos-arredores-da-fabrica-de-cimento-de-perus/. Acessado em 22 de janeiro de 2016.

${ }^{103}$ Realizada dia 13 de fevereiro de 2016 no CEU Perus.

104 Alguns trabalhos já foram dedicados para demonstrar o papel do programa Minha Casa Minha Vida para a reprodução do capital imobiliário financeiro. Um bom exemplo é "O programa Minha Casa Minha Vida: a mercadoria habitação a serviço da reprodução do capital em contexto de crise" (MARTINS, 2016).

${ }^{105}$ Em nota, família Peccicacco se posiciona sobre a demolição do casarão. Jornal Primeira Impressão, nov/2015. Disponível em: < http://jornalprimeiraimpressao.com/site/?p=14282 >. Acessado em $18 \mathrm{de}$ agosto de 2017. 


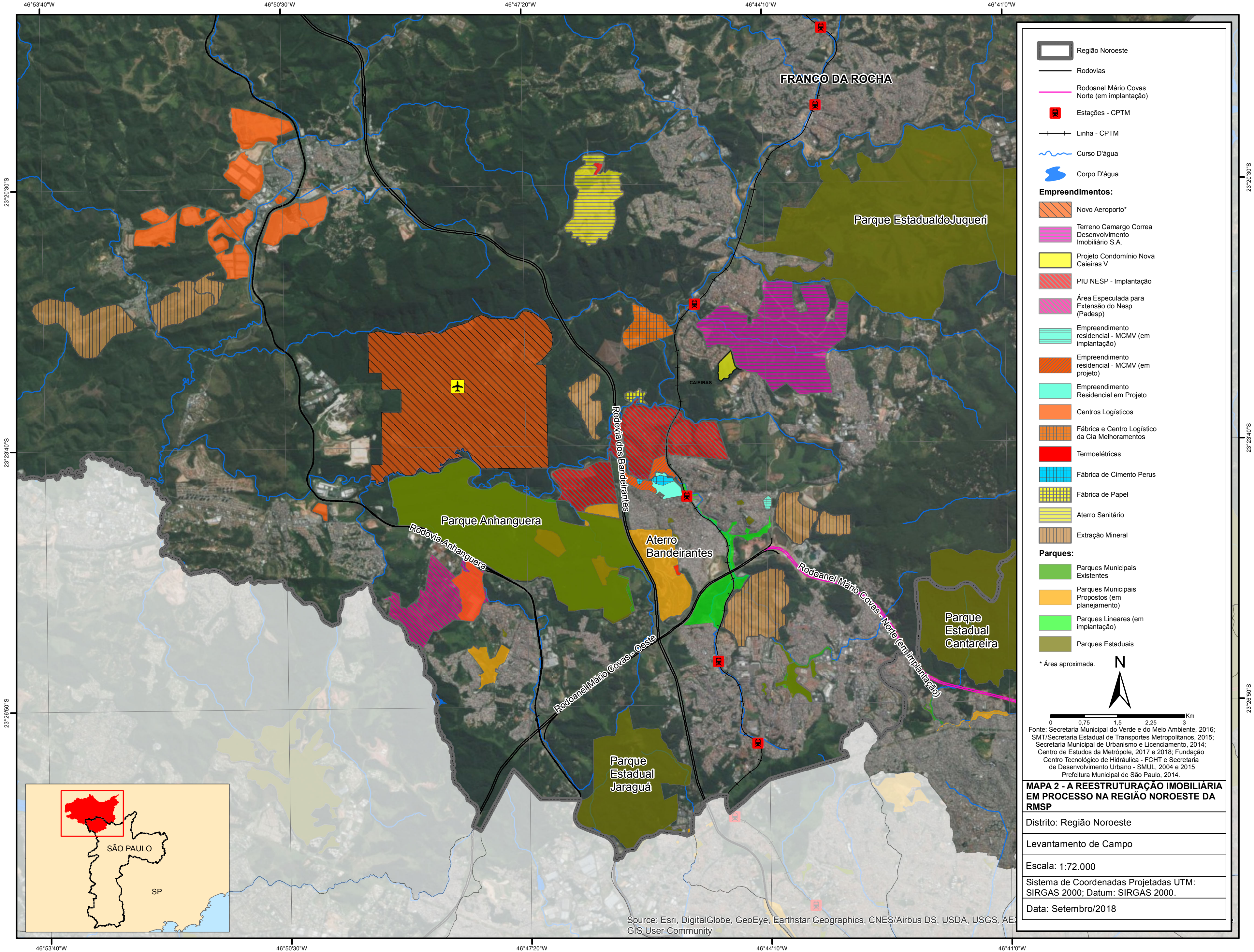


Nota-se portanto, que a rentabilização da terra, por negócios imobiliários, ocorre de distintas formas e escalas. A reestruturação imobiliária e a redefinição da situação geográfica estimula a mobilização da propriedade, independente de seu tamanho ou preços $^{106}$. Desse modo, variados produtos imobiliários são comercializados evidentemente, com expectativas de rentabilidade diferentes. A lógica de auferir renda não se realiza somente produzindo espaços altamente tecnológicos, com elevado grau de investimentos incorporados ao solo (como é o caso dos centros logísticos ou do novo aeroporto). Essa lógica se realiza também em proporções menores de investimento e retorno, o que aparece, por exemplo, com a construção de sobrados, "puxadinhos", conjuntos habitacionais para classe média baixa, loteamentos, compartimentação da casa, entre outras maneiras. Deve-se ressaltar que se para os agentes econômicos hegemônicos a produção do espaço é um meio de reprodução ampliada do capital, para os pequenos proprietários de terras da classe trabalhadora, trata-se de uma poupança, cuja rentabilidade é uma forma de garantir melhores condições para a reprodução da vida.

Perus ainda vive transição para um futuro incerto, haja vista que a reestruturação imobiliária ainda não se afirmou como realidade, cambaleia entre muitas especulações e algumas poucas ações concretas. Os novos tipos de ocupação do solo, que são os centros logísticos na Rodovia Anhanguera, alteraram pouco a disponibilidade de empregos em Perus, segundo alguns entrevistados. Há queixas de que os salários são muito baixos, que não há muitas vagas e que o acesso até os centros logísticos é difícil (por mais que estejam, relativamente, próximos). Logo, a dinâmica predominante ainda é a de um espaço periférico "dormitório". Nesse sentido, observa-se uma mobilização das propriedades imobiliárias em Perus para atender às necessidades de moradia das classes trabalhadoras.

Tá absurdo o preço dos alugueis, 700 reais dois cômodos, mas não está subindo mais porque senão não consegue alugar, isso porque eles colocam piso, azulejo, deixam a casa toda arrumadinha, a casa mais bonitinha é 700 reais, 800 reais. Normalmente os donos dos terrenos que alugam constrói uma casa pra cima, outra pro fundo e aluga, porque aqui não tem muito espaço pra construir. ${ }^{107}$

\footnotetext{
106 “Antes, era por suas ínfimas partes que a cidade entrava nos negócios e virava lugar de negócio. Agora ela, além disso, é um negócio inteiro situado na competição internacional. Observe-se contudo, que isto não suprime circuitos de valorização local; é importante considerar que estes viabilizam a reprodução do padrão vigente do espaço urbano, ao mesmo tempo que reproduzem os agentes econômicos" (SEABRA, 2003a, p. 379).

${ }^{107}$ Depoimento de Laura, sobre casas no Recanto dos Humildes.
} 
Esse tipo de atividade imobiliária pode ser vista, também, logo na entrada do Recanto dos Humildes, próximo à estação de trem e na frente do supermercado, onde se encontra um "corretor de imóveis", oferecendo e negociando casas e terrenos (Figura 6). Segundo ele, todas as casas têm título de propriedade. Esse mesmo rapaz negocia terrenos nos municípios vizinhos, Francisco Morato e Caieiras.

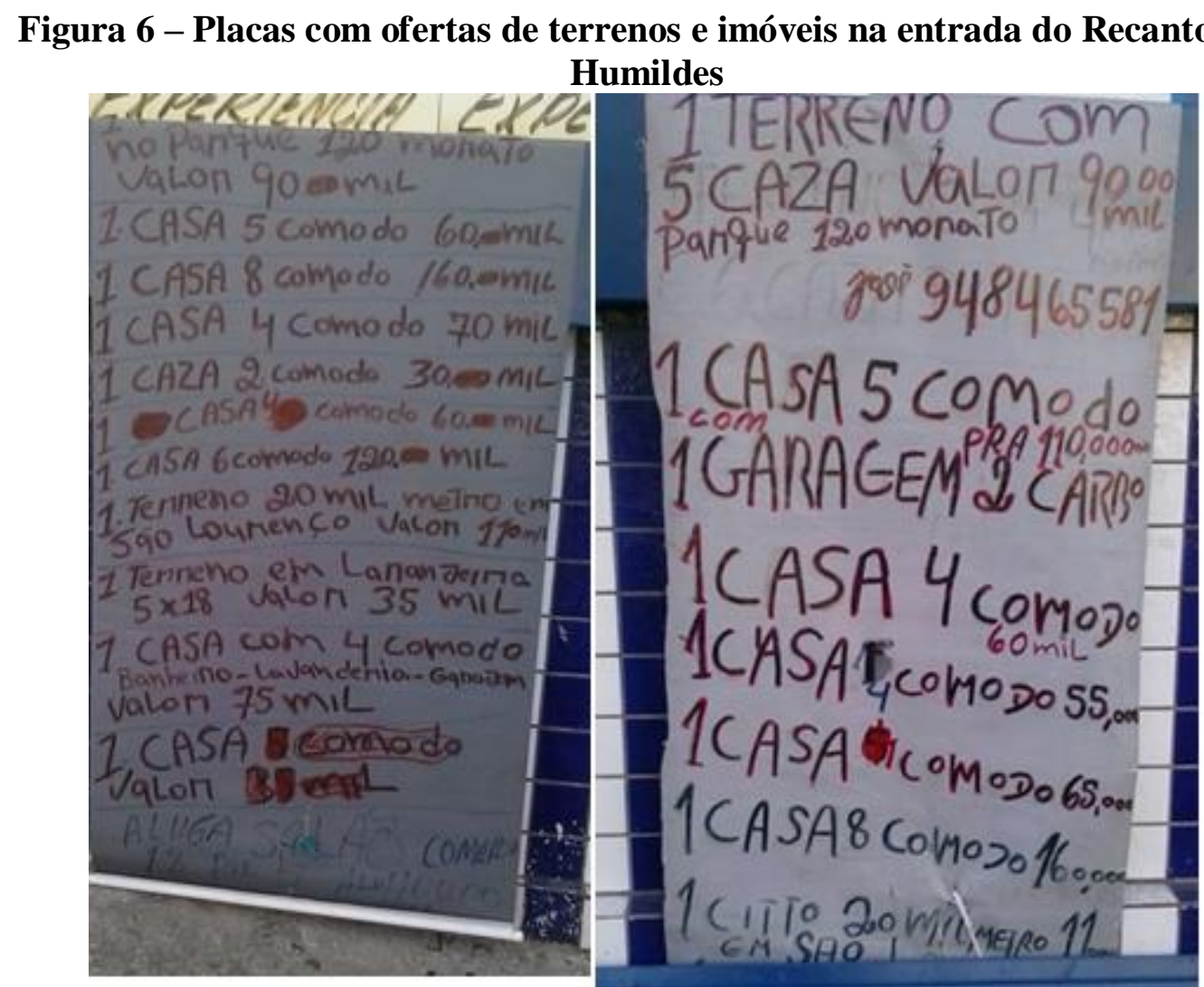

Fonte: Miguel Crochik (junho de 2016)

Observa-se, também, que as ocupações das terras sem uso em Perus não cessaram. A disputa pelo território vem ocorrendo nos últimos anos através de ocupações e reintegrações de posse. Uma delas iniciada em 2015, vizinha ao Recanto e próxima do Rodoanel, parece ter superado as diversas ações de desfazimento do Estado e está se consolidando. Nela, já existem casas feitas de bloco, comércios, e até encanamento da Sabesp. Segundo depoimento de Laura, um dos motivos para a ocupação ocorrer, foi a impossibilidade para alguns de se pagar o preço de aluguel no Recanto dos Humildes:

Muitas pessoas que mudaram agora pra essa invasão são pessoas que moravam de casas de aluguel, porque no Recanto é muita casa de aluguel, muita mesmo! Essa invasão foi muito das pessoas das casas de aluguéis, tanto que você passa hoje na rua e tem muita casa alugando, tem muita gente que morava em casa de aluguel, agora tá na área da invasão.

Por mais que algumas casas estejam vazias, observa-se uma demanda de pessoas por casas na região. Nesse sentido, é importante destacar as migrações atuais para essa 
área da metrópole. Parte das pessoas que tem alugado casas no Recanto dos Humildes são imigrantes angolanos, moçambicanos, bolivianos e, especialmente, haitianos. Como estratégia para pagar os valores de aluguel relativamente altos, muitas vezes, vários imigrantes dividem a mesma casa ${ }^{108}$.

Em diversos depoimentos realizados pelos moradores de Perus, houve relatos de aumento expressivo nos preços imobiliários da região, a partir dos últimos quinze anos. Dentre outros motivos que explicam o fenômeno, podemos destacar que o Rodoanel reinsere as terras da região no conjunto da metrópole, tornando-as mais valorizadas e atraindo ainda mais investimentos imobiliários, que tornam a valorização espacial exponencial. Nesse sentido, a reestruturação imobiliária está associada a um processo de gentrificação $^{109}$ (Smith, 2007). No distrito de Perus, especificamente, poucas obras de requalificação espacial - que desencadeariam uma gentrificação acelerada - realizaramse de fato. Mesmo assim, a combinação dessas poucas obras com muitas especulações imobiliárias resultou em um crescimento nos preços imobiliários, o que fez com que as pessoas tivessem que se readequar para poder morar, através de distintas estratégias como, por exemplo: ocupar espaços sem uso, dividir aluguel, migrar para outra cidade ou bairro, entre outras formas. Os relatos sobre os destinos mais procurados para aqueles que saem do bairro, mostram que a migração é, em geral, para cidades mais ao norte da RMSP. "Eu conheço pessoas que querem sair, querem alugar em outro lugar, no lado de Franco da Rocha, Francisco Morato, tão tentando, vendo terreno para comprar ou alugar para lá, porque subiu muito (o preço do aluguel em Perus), tá difícil para continuar né?!"110. O que indica uma reprodução do padrão periférico, que destina as lonjuras para os pobres.

Uma ação específica, de requalificação do espaço, feita pelo Estado, foi decisiva para o aumento vertiginoso dos preços imobiliários: as remoções, entre 2010 e 2013, de 294 famílias que viviam nas margens do córrego das Laranjeiras, sob a argumentação de que se tratava de uma área de risco. Para o local, a PMSP planejou construir um conjunto de habitações sociais e um pequeno parque linear ${ }^{111}$. Para a maior parte dos removidos, foi assegurado o pagamento de auxílio-aluguel no valor de $\mathrm{R} \$ 450,00$, até

\footnotetext{
${ }^{108}$ Há que se destacar que para esse tipo de migrante, a entrada no mercado de trabalho formal é mais difícil, por vários motivos, como, por exemplo, pela dificuldade com a língua. Nesse sentido, ter um endereço é um quesito que contribui para essa inserção.

${ }^{109}$ Mudança do perfil de classe social, dado pelo enobrecimento da população que ocupa determinado lugar e o consequente afastamento para mais longe da população mais pobre que vivia nesse espaço, devido ao aumento dos preços imobiliários e dos custos de vida.

${ }^{110}$ Depoimento de Romero.

${ }^{111}$ Uma análise mais detalhada desse projeto será realizada no capítulo 3.
} 
que a obra fosse concluída. Esse fenômeno serviu para aquecer o mercado imobiliário de Perus, pois muitas famílias queriam continuar morando no bairro. Os preços dispararam a partir desse evento. Janaína, moradora do bairro e antiga militante da CEB, refere-se a esse momento como uma estratégia para agir sobre os preços imobiliários: "Quem comprou essa história do aluguel social como defesa dos moradores foi um engodo, porque foi pra favorecer o comércio imobiliário. A moradia, o aluguel em Perus cresceu demais, você não encontra uma casa por menos de 500 reais ${ }^{112}$ ".

A escalada dos preços parece ter se estabilizado (mas não diminuído) nos últimos anos. No entanto, é notável que essa obra de requalificação urbana proposta em um trecho do córrego das Laranjeiras foi significativa dentro de um processo de gentrificação. Essa ação do Estado tinha como uma das justificativas o fato de se construir um "conjunto habitacional sustentável" no local, que buscaria, de alguma forma, reestabelecer uma relação harmônica com a natureza. Nesse sentido, essa não foi uma ação isolada do Estado. Ela faz parte de um conjunto de medidas urbanísticas sustentáveis previstas para Perus. A hipótese que será debatida ao longo dessa dissertação é que esse conjunto de ações estão em consonância com o processo de reestruturação imobiliária da região e, consequentemente, com a gentrificação.

Materialmente, a reestruturação imobiliária em curso em Perus tem como característica marcante a fragmentação e transformação de grandes terrenos rurais ou semi-rurais em espaços urbano-sustentáveis ou em espaços urbano-logísticos.

\footnotetext{
${ }^{112}$ No item no capítulo 4.3, o assunto das indenizações por remoção será novamente abordado.
} 


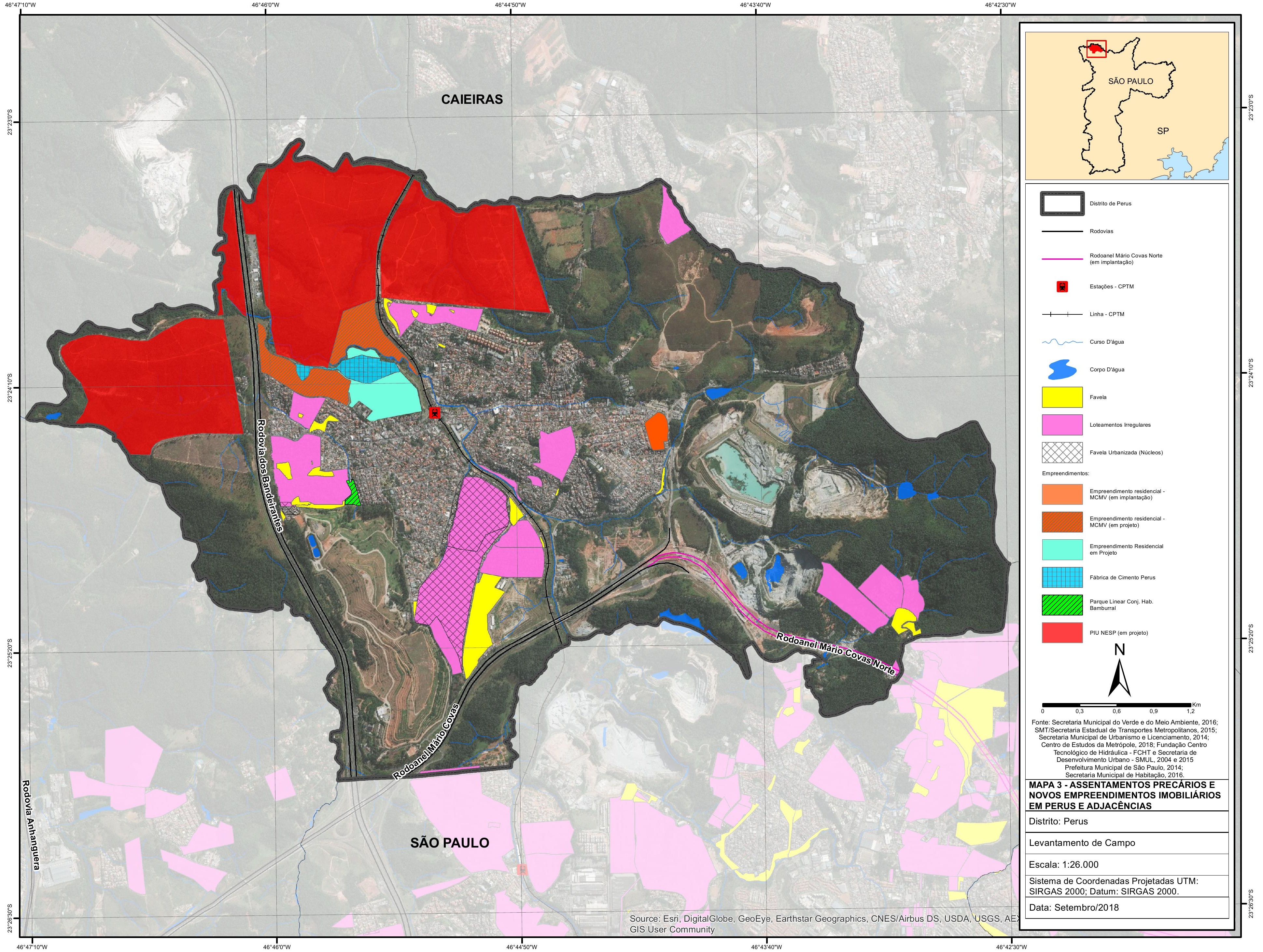


Resumindo a ideia geral desse subcapítulo: a região noroeste guarda muitos terrenos para expansão urbana, no entanto, esse avanço é feito de forma controlada e coordenada pelo Estado, pelos proprietários e capitalistas que especulam sobre os terrenos e os liberam em momentos de maior possibilidade de ganhos. Nesse processo, os grandes proprietários de terras personificam o processo de reestruturação produtiva, já que tendem a deixar de ser capitalistas industriais/agrícolas/mineradores (como foram em um momento anterior) e estão cada vez mais se transformando em rentistas, desfazendo-se de suas unidades produtivas e obtendo rendimentos pela venda e arrendamento de suas propriedades territoriais, ou constituindo ramos de negócios imobiliários em suas empresas ${ }^{113}$. As terras do noroeste da RMSP entram no processo de reestruturação imobiliária (capitaneado pelo Rodoanel) basicamente de duas formas na região noroeste: como centros logísticos ou como condomínios residenciais destinados aos setores sociais de rendimentos médios e baixos. Espacialmente, isso significa uma transformação de terrenos rurais ou semi-rurais em espaços urbanosustentáveis ou em espaços urbano-logísticos. Essa expansão urbana, pautada por esses empreendimentos, supera a limitação para urbanização desse sítio geográfico acidentado através de obras de terraplanagem nos topos dos morros.

A valorização imobiliária dos últimos anos expulsou algumas pessoas de Perus, mas não alterou drasticamente o perfil social do distrito. A redefinição nos usos dos espaços que se observa ainda é tímida, permanecendo o bairro como tipicamente periférico. No entanto, há algumas tentativas do poder público para requalificar essa área. Busca-se criar uma nova centralidade, cujas características marcantes seriam de um "bairro logístico e sustentável". Para observar esse movimento, é necessário contextualizar como surgem esses projetos urbanísticos sustentáveis.

\subsection{O papel dos créditos de carbono na reestruturacão imobiliária}

Não é possível decifrar o papel da sustentabilidade na reestruturação imobiliária de Perus sem compreender a relação entre o bairro e o Aterro Sanitário Bandeirantes. Desde sua fundação, em 1979, esse receptáculo de resíduos domésticos foi sempre um estorvo na vida dos habitantes de Perus. Além do mau cheiro, da presença de insetos e ratos, o lixão trouxe uma série de doenças respiratórias e de pele para os moradores. A

\footnotetext{
${ }^{113}$ Essa inferência sobre esses proprietários só se aplica às suas ações na região noroeste da RMSP. Não se tem informação se em outros lugares eles ainda mantém grandes unidades industriais.
} 
comida cozinhada tinha logo que ser guardada, caso contrário, as várias moscas poderiam pousar sobre ela.

Do ponto de vista da tecnocracia gestora do espaço metropolitano, a situação geográfica de Perus é favorável para a instalação de Aterros Sanitários: está nas margens de duas rodovias, tem ampla disponibilidade de terrenos para acumular resíduos, está próxima do grande produtor de resíduos (a cidade de São Paulo), além de estar distante dos espaços frequentados pelas elites. A redefinição espacial proposta pelo Rodoanel tornou a região noroeste ainda mais propícia para sediar aterros, devido à facilitação para chegada de caminhões de diversas regiões. Afinal, a gestão de resíduos de uma grande cidade é também uma questão logística. Se são necessários espaços bem localizados para distribuir a infinidade de mercadorias consumidas, também o são para descartar seus restos.

O processo de metropolização e o crescimento constante da produção de lixo fez com que a gestão desses materiais se tornasse uma potencial atividade lucrativa, sendo parte constituinte de um novo tipo de indústria, que surgiu nas últimas décadas do século XX, a indústria da despoluição (SEABRA, 2003b). Como veremos mais adiante, é inerente à lógica capitalista transformar um problema social em um negócio potencialmente lucrativo. Isso se verificou em São Paulo, por exemplo, através da terceirização da gestão do Aterro Bandeirante, repassada da PMSP para a Loga ${ }^{114}$.

No início da década de 2000, esse Aterro já mostrava estar no fim de sua vida útil. A partir de então, dada a raridade do espaço, diferentes terrenos da região noroeste passaram a ser objetos de interesse do Estado e de empresas para receber mais um aterro sanitário, totalmente privado. A Ecolar Ecologia, Ambiente e Resíduos ${ }^{115}$ era a empresa interessada em realizar esse empreendimento em Perus. Alguns terrenos vagos foram especulados para sediar o novo aterro, dentre eles: um ao lado do Parque Anhanguera, outro ao norte do distrito de Perus (onde hoje está previsto para ser o Nesp), além de outro no distrito de Anhanguera (ao lado do acampamento Irmã Alberta).

Entre os anos 2000 e 2006, houve diversas situações em que a população de Perus se organizou e insurgiu contra a instalação de mais um Aterro Sanitário e, também, pelo fechamento do já existente. Sem dúvida, a identidade de lutas incrustadas na história de lutas do bairro foi decisiva para essas grandes mobilizações, que

\footnotetext{
${ }^{114}$ Empresa do grupo transnacional Solví, que por sua vez é uma holding controladora de mais de 30 empresas nos segmentos de Resíduos, Saneamento, Energia e Engenharia.

${ }^{115}$ Empresa do grupo Vega, que na época pertencia à transnacional francesa Situ. Anos mais tarde seria incorporado pelo grupo Solví.
} 
conseguiram bravamente barrar todos os projetos de novos Aterros para Perus, através da pressão popular, exercida em um novo momento de união de grupos do bairro. Por meio dos movimentos "Lixão, mais um não", "SOS Fora Lixão" entre outros, a população se organizou e lutou, realizando trabalho de base, manifestações em avenidas e rodovias, abaixo-assinados e até um acorrentamento no portão do Aterro Bandeirantes. Esse último evento, já em 2006, foi para pressionar o fechamento desse aterro, o que, de fato, veio a se confirmar. Nessas situações a população de Perus reviveu seus melhores dias de lutas por melhores condições de vida urbana ${ }^{116}$.

Contudo, o novo Aterro Sanitário foi realmente construído na região noroeste, só que no município de Caieiras. Por lá também houve mobilização contra esse projeto, no entanto, insuficiente para barrá-lo. De modo que, desde 2003, está em operação uma área receptora de resíduos, totalmente privada, gerida pela empresa Essencis Soluções Ambientais - que também era integrante do grupo Situ e, posteriormente, Solví.

A influência do Aterro Sanitário Bandeirantes sobre o bairro de Perus não acabou quando esse parou de receber resíduos. Isso porque essa estrutura - que durante muitos anos era considerada como uma externalidade negativa ${ }^{117}$ do processo de produção - foi ressignificada com a ascensão da chamada economia verde ${ }^{118}$ e da indústria da despoluição, de modo que, essa verdadeira montanha de lixo, passou a atrair atenção dos investidores, pois poderia produzir uma modalidade de "energia limpa", além de poder gerar ativos financeiros - os chamados créditos de carbono.

Essa ressignificação foi decisiva para o bairro de Perus, pois o dinheiro arrecadado pela venda dos créditos de carbono acabaria sendo reinvestido na região, através da projetos de "urbanismo sustentável". Observemos esse complexo processo passo a passo.

O Aterro Bandeirantes foi durante 25 anos um dos principais destinos de resíduos da cidade de São Paulo, recebendo 35 milhões de toneladas nesse período em uma área aproximada de 140 hectares. Quando de sua desativação, no início de 2007,

\footnotetext{
116 Deve-se destacar que em 1995, o ex-prefeito Paulo Maluf chegou a desapropriar 34 mil metros quadrados, de um total de 400 mil metros quadrados, para instalar um incinerador de lixo. O local também ficava próximo ao parque Anhanguera, mas o projeto não saiu do papel, pois, na época, os moradores fizeram veemente protesto paralisando as rodovias, avenidas e até a estação de trem.

117 Termo da economia política para se referir consequências da produção que são negativas para terceiros, como, por exemplo, uma fábrica que polui a atmosfera ou a água.

118 Trata-se de um novo ramo de negócios surgido a partir da crise econômica dos anos 1970. A partir da quantificação e mercantilização de algumas externalidades negativas da produção, é estabelecido um novo mercado. Ele é parte integrante do processo de reestruturação produtiva. Uma análise mais aprofundada sobre o tema será realizada no capítulo 2.
} 
recebia aproximadamente sete mil toneladas diárias, ou seja, a quantidade equivalente à metade do lixo produzido na cidade (Rizzi, 2011). Os resíduos orgânicos acumulados no solo passam anos em processo de decomposição, liberando à atmosfera gases como o metano, que acentua o efeito estufa antropogênico. Esses gases, se queimados, podem ser utilizados como combustível para a produção de energia. Dessa forma, o aterro deixa de ser só um acumulo indesejado de resíduos e passa a ser visto como uma grande reserva de combustível. No entanto, o investimento na transformação desse gás em energia elétrica é mais caro se comparado a outras matrizes energéticas. O que o torna rentável é também poder gerar outra mercadoria, o crédito de carbono.

Esse tipo de produção de energia "sustentável" é considerado pela Organização das Nações Unidas (ONU) - de acordo com os termos Protocolo de Quioto ${ }^{119}$ - um Mecanismo de Desenvolvimento Limpo (MDL) e que, por isso, gera créditos de carbono: um certificado de não-emissão para a atmosfera dos gases que podem intensificar o efeito estufa antropogênico. Esse certificado tem preço e pode ser vendido a quem tiver interesse de comprar. As compradoras são, normalmente, empresas que extrapolam os limites de emissão de Gases de Efeito Estufa (GEE) - estabelecidos a partir de Quioto - na produção de suas mercadorias e, por isso, adquirem créditos de empresas que "limpam" a atmosfera desses gases. Também atores do mercado financeiro, são potenciais compradores desse tipo de ativo, com a finalidade de revendêlo posteriormente, em um momento de aumento do preço, funcionando, assim, como uma ação qualquer da bolsa de valores. Segundo o Protocolo de Quioto, os chamados países desenvolvidos são os que têm que bater metas de diminuição de emissão de GEE:

O MDL parte do compromisso de redução de emissão de $\mathrm{CO}^{2}$ dos países desenvolvidos e pode ser realizado nos países em desenvolvimento. $\mathrm{O}$ princípio adotado é que, embora as emissões dos gases sejam feitas localmente a sua grande dispersão na atmosfera tem efeitos globais, criando a possibilidade de comércio de emissões entre países (CONEJERO, 2006, p. 10 apud RIZZI, 2011).

Dessa forma, uma empresa poluidora de um "país desenvolvido" - com metas de redução de gases poluentes - compra Reduções Certificadas de Emissões (RCE), os créditos de carbono, de empresas de "países em desenvolvimento", controlando a

119 O Protocolo de Quioto é um tratado internacional, ratificado em 1999. Os países signatários assumiram compromisso para a redução da emissão dos gases que agravam o efeito estufa antropogênico. Para isso, foram institucionalizados mecanismos de mitigação das mudanças climáticas, como a comercialização de "cotas de carbono". O Protocolo de Quioto foi renovado em 2012, porém, como nenhum dos países centrais da economia mundial ratificou o tratado, ele perdeu sua efetividade, de modo que o mercado internacional de créditos de carbono diminuiu significativamente a partir de então. 
emissão global desses gases na atmosfera ${ }^{120}$. As vistorias dos projetos de MDL, assim como das transações financeiras, ocorrem sob o referendo da ONU e do Banco Mundial, que garantem a institucionalização da comercialização de moléculas da atmosfera global. Dessa maneira, uma empresa transfere para a outra o direito de propriedade de um certificado que a desobriga de diminuir seus índices de poluição atmosférica. Em outras palavras, a compra de RCE autoriza a empresa a emitir GEE. A transação desse papel financeiro pode mobilizar montantes de capital de ordem milionária.

Por conta dos termos estabelecidos pelo Protocolo de Quioto, um Aterro Sanitário deixa de ser - do ponto de vista do capital - uma externalidade negativa e se torna um ativo financeiro. Assim, em 2003, a PMSP firmou um acordo com a Biogás Energia Ambiental S.A. e o Unibanco S.A. para explorar os 2,4 bilhões de metros cúbicos de biogás (nome dado ao gás oriundo da decomposição dos resíduos orgânicos) contido no solo do Aterro. Através do "Projeto Bandeirantes de Gás de Aterro e Geração de Energia", estabeleceram-se as bases para a construção de uma usina termoelétrica em Perus. Segundo o projeto $^{121}$, referendado pela ONU, esse empreendimento pode gerar 22 megawatt de energia elétrica e, também, ser uma solução ambiental e financeira para evitar que o gás do aterro atinja em grande monta a atmosfera, evitando o agravamento do efeito estufa antropogênico ${ }^{122}$.

Os termos do acordo foram os seguintes: o Unibanco S.A. ${ }^{123}$ foi responsável por financiar a elaboração do projeto e, também, por viabilizar a maior parte do montante necessário para a construção da planta industrial da usina termoelétrica. Parte dos recursos veio através de um convênio com o Banco do Japão para Cooperação Internacional, em um total de US\$50 milhões. O Unibanco, também, contratou a empresa Sotreq, representante da estadunidense Caterpillar, para fornecer os motogeradores da Usina.

A Biogás Energia Ambiental S.A. ${ }^{124}$, por sua vez, investiu uma quantia menor que o Unibanco em capital constante. Porém, é essa empresa a responsável por gerir a

\footnotetext{
${ }^{120}$ É importante destacar que esse tipo de tratado internacional aprofunda o desenvolvimento desigual.

${ }^{121}$ Para visualização integral do projeto, ver: <http://cdm.unfccc.int/Projects/DB/DNV-

CUK1134130255.56/view>. Acessado em 05 de agosto 2016.

$122 \mathrm{O}$ processo de queima do gás metano tem como produto final o gás carbônico, que é emitido à atmosfera. No entanto, o metano é considerado 21 vezes mais impactante que o gás carbônico para o agravamento do efeito estufa antropogênico. Por isso, seu valor no mercado de créditos carbono é proporcionalmente superior. Também por isso a Termoelétrica é considerada um MDL.

123 Posteriormente comprado pelo Banco Itaú, transformando-se em Unibanco-Itaú e depois em Itaú.

124 “Consórcio formado pela Arcadis Logos Engenharia, da área de projetos energéticos do grupo Logos Engenharia, pela Heleno \& Fonseca, construtora e operadora do aterro Bandeirantes e pela holandesa Van Der Wiel, especializada em projetos de desgaseificação” (Revista Elo, 2005 apud RIZZI, 2011a)
} 
produção de energia através da combustão do biogás. A PMSP, por sua vez, entra no acordo, pois é proprietária do terreno do Aterro e, por isso, tem direito a $50 \%$ dos créditos de carbono produzidos. Os outros $50 \%$ são de propriedade da Biogás S.A. ${ }^{125}$

Ao Unibanco, precursor e principal investidor do projeto, destina-se a produção de energia elétrica da usina: em um acordo ratificado em 2005 entre o banco, a PMSP e a Agência Nacional de Energia Elétrica (ANEEL), foi concedida isenção de custos com energia elétrica para as agências na cidade de São Paulo, para as sedes corporativas e, também, para outras empresas agregadas ao grupo ${ }^{126}$. O acordo previu a isenção durante uma década. Segundo o projeto, a Termoelétrica Bandeirantes pode gerar energia elétrica para abastecer uma cidade de até 300 mil habitantes. Contudo, na prática, grande parte dessa capacidade foi direcionada para o consumo do Unibanco (e posteriormente do banco Itaú) ${ }^{127}$ (Rizzi, 2011a).

O Aterro Bandeirantes gerou milhões de toneladas de Reduções Certificadas de Carbono, que foram acumuladas e negociadas em seguida. Os créditos pertencentes à Biogás são negociados diretamente com o Banco Alemão KfW Group ${ }^{128}$, desde 2006. Os valores não são divulgados, mas têm como base o preço médio da RCE no mercado europeu.

A Prefeitura de São Paulo optou por vender seus créditos na BM\&F Bovespa em três leilões diferentes. No primeiro, em 2007, arrecadou R\$ 34,7 milhões com a venda de 808.450 RCE para o banco belgo-holandês Fortis. Em 2008, vendeu mais 713.000 RCE à empresa suíça Mercuria Energy Trading ${ }^{129}$, sendo 454.343 certificações correspondentes ao Aterro Bandeirantes e 258.657 ao Aterro São João. O valor total arrecadado foi de cerca de $\mathrm{R} \$ 37$ milhões. De 2008 a 2012, a PMSP não leiloou créditos de carbono devido à crise financeira global, que rebaixou muito os preços das certificações. Em 2012, no terceiro e último leilão, a arrecadação foi muito menor: $\mathrm{R} \$ 4,4$ milhões por aproximadamente 530.000 RCE, também vendidas à Mercuria

\footnotetext{
${ }^{125}$ A PMSP com a Biogás também tem parceria na produção de energia no Aterro São João, na zona Leste de São Paulo.

${ }^{126}$ Despacho ${ }^{\circ} 321$ registrado pela ANEEL de 14 de março de 2005.

${ }^{127}$ A energia gerada pela Termoelétrica é administrada pela Biogeração S.A., que pertence ao banco. Ela revende o excedente de energia produzida para outros consumidores. Na prática, a Biogeração passa toda a energia produzida para a rede da cidade e a Eletropaulo credita para a empresa do Unibanco o mesmo volume fornecido.

${ }^{128}$ Trata-se de um banco público alemão criado em 1948 para gerir os recursos do Plano Marshall. Atualmente atua, sobretudo, como interface do governo alemão com os países em desenvolvimento, tendo foco em projetos voltados para sustentabilidade. Retirado de < https://www.kfw.de/KfW-Group/About$\mathrm{KfW} /$ ?kfwmc=kfw-stories $>$ em 10 de outubro de 2015.

${ }^{129}$ Empresa que tem atuação centrada no comércio mundial de petróleo, mas que atua com diversos tipos de commodities, especialmente as do ramo energético.
} 
Energy Trading. No último leilão, o preço de cada RCE foi de 3,30 euros, muito menor do que os 19,20 euros do segundo leilão ou 16,20 euros do primeiro.

Tabela 4 - Arrecadação da PMSP com os leilões dos créditos de carbono

\begin{tabular}{|l|c|c|c|}
\hline ANO & $\begin{array}{c}\text { Quantidade de toneladas } \\
\text { de carbono negociadas }\end{array}$ & $\begin{array}{c}\text { Valor aproximado arrecadado } \\
\text { (em milhões de reais) }\end{array}$ & $\begin{array}{c}\text { Preço da tonelada de } \\
\text { carbono (em euros) }\end{array}$ \\
\hline 2007 & 808.450 & 34,05 & 16,20 \\
\hline 2008 & 713.000 & 37 & 3,30 \\
\hline 2012 & 530.000 & 4,5 & 19,20 \\
\hline
\end{tabular}

Desde então, a produção de energia e de créditos de carbono no Aterro Bandeirantes continua. Entretanto, nenhuma outra venda foi feita pela PMSP, que segue acumulando RCE, à espera de que o preço dessa mercadoria aumente nos próximos anos. Soma-se à crise econômica global, o fato do Protocolo de Quioto ter sido renovado sem a participação dos países com as principais economias do mundo, de modo que os preços dos créditos de carbono têm estado abaixo do que a PMSP considera razoável para vendê-los.

Nota-se, portanto, que a ascensão da indústria da despoluição gerou a possibilidade de extração de uma maior renda fundiária no terreno do Aterro, que se traduziu em créditos de carbono para a PMSP. A gestão municipal reverteu esse dinheiro em projetos urbanísticos "sustentáveis" na região noroeste. Essa foi uma iniciativa inédita de uma prefeitura, ao captar recursos no mercado financeiro internacional, através da comercialização de RCE, e aplicá-los em obras urbanas. Esses investimentos foram apresentados e propagandeados como algo que poderia sanar uma série de problemas existentes no bairro periférico de Perus e, mais do que isso, seria um meio de resgatar parte da dívida social com a comunidade, por conta dos anos convivendo com o lixão.

\footnotetext{
${ }^{130}$ Créditos de carbono da Prefeitura são arrematados em leilão por R\$ 34,05 milhões, PMSP, set/2007. Disponível em < https://www.prefeitura.sp.gov.br/cidade/secretarias/comunicacao/noticias/?p=132347 > 23 de out. de 2018; Prefeitura arrecada R $\$ 37$ milhões no $2^{\circ}$ Leilão de Créditos de Carbono, PMSP, set/2008. Disponível em < https://www.prefeitura.sp.gov.br/cidade/secretarias/fazenda/noticias/?p=5293 > acessado em: 23 de out. de 2018; Prefeitura arrecada R \$ 4,5 milhões em leilão de créditos de carbono, PMSP, jun/2012. Disponível < https://www.prefeitura.sp.gov.br/cidade/secretarias/comunicacao/noticias/?p=106989 > 23 de out. de 2018.
} 
Figura 7 -

DIAGRAMA DE EMPRESAS E PRODUTOS RELACIONADOS

À TERMOELÉTRICA BANDEIRANTES

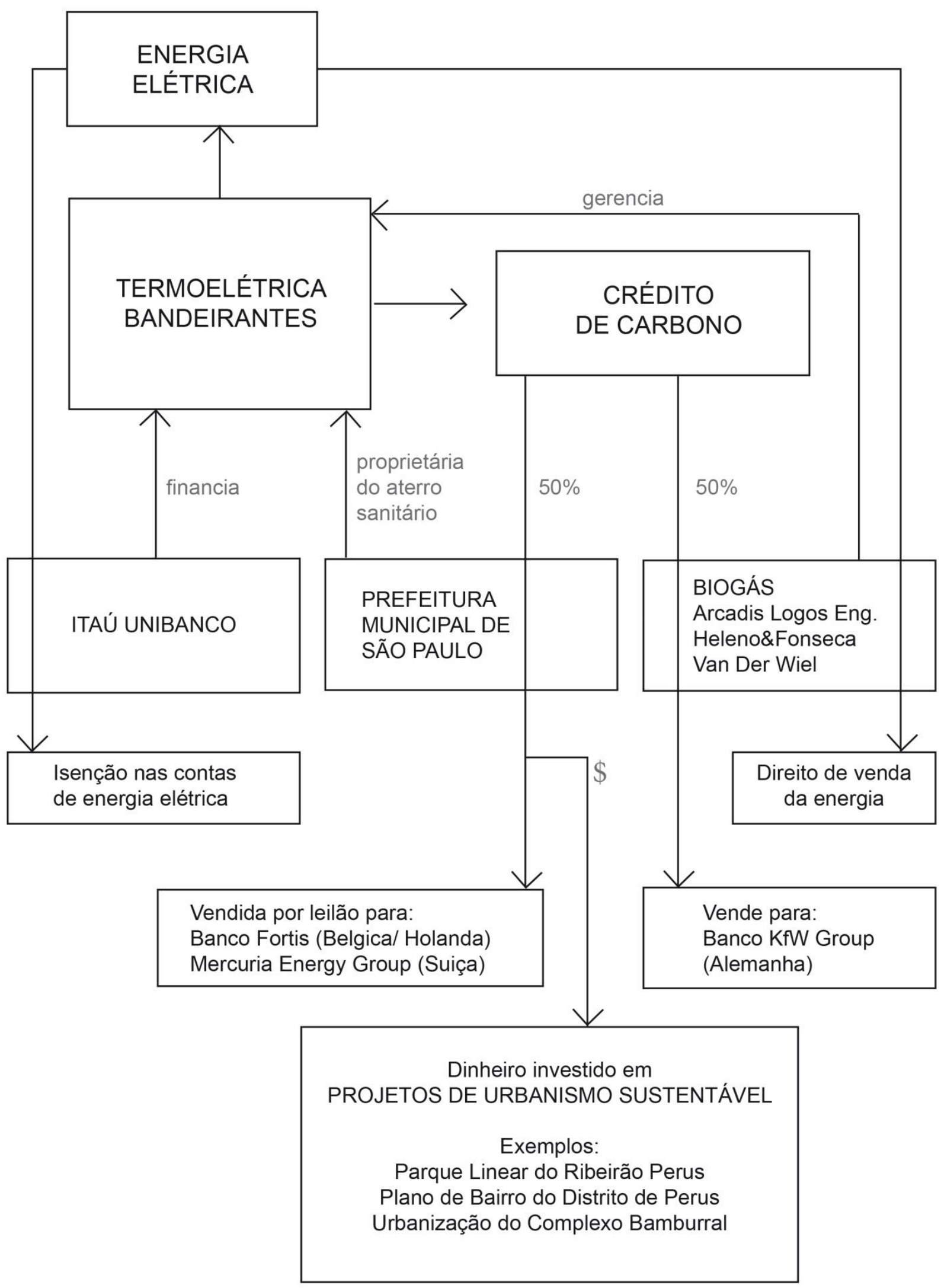




\subsection{O material e o simbólico na reestruturacão imobiliária}

Do ponto de vista da reestruturação imobiliária, esses investimentos urbanos pagos com o dinheiro dos créditos de carbono - fazem parte de um conjunto de fatos que buscam atrelar ao bairro de Perus uma imagem de local ambientalmente equilibrado. Outro fato que corrobora para essa imagem de sustentável, que se busca imputar à Perus, parte de uma mudança de interpretação recente sobre existência de áreas vegetadas da região. Os vários hectares rurais do entorno de Perus - oriundos da silvicultura e outros tipos de produção agropecuária - passaram a ser enxergados como áreas que colaboram com "sustentabilidade" em uma metrópole caracterizada pela escassez de áreas verdes. O que era área de produção de matéria-prima e de especulação imobiliária ganhou um novo valor de uso e passou a ser visto como "saudável para o meio ambiente".

Além disso, a posição da região noroeste, em meio a diversas unidades de conservação, traz mais fundamentos à representação desse bairro como "sustentável". A partir dos anos 1960, começaram a surgir as primeiras áreas de preservação ambiental na região noroeste da capital Paulista. Em 1961, foi criado o Parque Estadual do Jaraguá e, em 1963, o Parque Estadual da Serra da Cantareira. Ambos são vizinhos próximos de Perus, muito importantes para a conformação que a paisagem do entorno do bairro tem nos dias atuais. Em 1979, foi criado o Parque Anhanguera, maior parque municipal de São Paulo ${ }^{131}$, sobre parte da área de silvicultura da família Abdalla. Mais ao norte, nos municípios de Caieiras e Franco da Rocha, está outra grande unidade de conservação, o Parque Estadual do Juqueri, criado em 1993, em parte das terras do antigo Hospital Psiquiátrico do Juqueri.

Tanto na materialidade, mas ainda mais no nível das representações, a existência desses parques e das áreas rurais remanescentes traz maior aderência à ideia de que Perus é um lugar ambientalmente mais equilibrado e, portanto, "mais sustentável".

O fim da poluição da fábrica e o fim do Aterro Sanitário (enquanto receptor de resíduos) - objetos de lutas históricas da população por melhores condições de saúde e habitabilidade - também são interpretados nos dias de hoje como conquistas ambientalistas e, também, são fatos utilizados para justificar a "marca de Perus sustentável”.

\footnotetext{
${ }^{131}$ Com área superior a 9500000 metros quadrados, o equivalente a mais de oito vezes a área do Parque
} do Ibirapuera, localizado na zona sul da cidade. 
A existência da Termoelétrica Bandeirantes, que colabora para o controle global das mudanças climáticas, também aparece no imaginário social como uma contribuição de Perus para a sustentabilidade.

A todos esses fatores, juntam-se os projetos urbanísticos sustentáveis, pagos pelos créditos de carbono, sendo esses mais um dos fatores que tornam possível colar a Perus a concepção de ambientalmente equilibrado. Nesse sentido, devemos observar que a reestruturação imobiliária não se dá somente como um processo material, haja visto que essa reprodução também se dá no nível simbólico.

Como já destacado, o movimento de passagem do fordismo à produção flexível redefine usos dos espaços. No espaço urbano, o capital busca áreas desvalorizadas que possam ser novas centralidades. Segundo Benach (2004), nessa transição de modalidades de uso, fazem-se necessários discursos que legitimem, frente à população, a adequação de seu espaço às novas modalidades de reprodução do capital. O discurso ambiental tem sido uma das justificativas desse processo, sendo desviado de sua origem contestadora e apropriado para a reprodução do espaço urbano.

Não se trata aqui de debater se Perus é mais ou menos sustentável. Buscar-se-á investigar como essa nova representação do espaço de Perus atinge o imaginário social e defender a hipótese de que ela é benéfica para o mercado imobiliário. Isso pode ser notado, por exemplo, nos anúncios de publicidade dos empreendimentos imobiliários do bairro, nos quais são comuns os destaques da "bela vista do local" como um diferencial, de onde se observa diferentes áreas verdes. Também o ar puro da região é tratado como atrativo publicitário ${ }^{132}$. O invólucro de "bairro sustentável" criado é uma ressignificação desse espaço historicamente construído. Sem dúvida, esse rótulo é aproveitado pela indústria imobiliária, que busca afastar a percepção desse lugar como sendo periférico ou operário. Essa abrupta passagem é estratégica.

Ou seja, para transformar Perus em uma mercadoria imobiliária mais atrativa, aposta-se na persuasão de que a "marca" do bairro é o seu equilíbrio ambiental. Esse convencimento tem que se dar sobre a sociedade como um todo e, mais especificamente, sobre a própria população local. Para o andamento desse processo de

132 Nos anos setenta, George (1973) já observava a consolidação desse fenômeno publicitário ambientalista: "Afirma-se que o citadino é um nostálgico da vida campestre (afirmação que comporta muitas nuanças), o que leva a criar em torno de sua residência um cenário capaz de lhe recordar o campo. A terminologia das agencias imobiliárias, neste setor, é bastante significativa, e traduz os desejos e condicionamentos do citadino. Garante-se a vista panorâmica, dando-se preferência à implantação sobre topografias acidentadas que descortinem perspectivas superpostas. A natureza é representada pelo sítio, à margem de um rio ou de uma floresta em escala reduzida, aproveitando acidentes naturais do terreno ou criados artificialmente graças ao plantio de árvores e gramados" (Ibid., p. 29). 
transformação espacial do bairro - que tem como fim uma reinserção no circuito imobiliário de capitais - a difusão de uma série de discursos "oficiais" se faz necessária, para que a própria população local aceite essas transformações, identifique-se com elas, encampe-as no nível das representações, evitando, assim, conflitos e gerando uma "cidadania-bloco": "um grau de consenso naquilo que é discutido de modo a não questionar o objetivo geral, que não é outro que o estímulo do econômico" (BENACH, 2004, p. 75).

Esses discursos são disparados por agentes hegemônicos e vão sendo encampados pela sociedade, de modo que se legitima socialmente o processo de reestruturação produtiva - que, no urbano, significa a capitalização do espaço. Um dos agentes que difunde essa mensagem é a própria PMSP, difusora de uma representação do que seria "Perus renovado", através de projetos urbanísticos.

Desse modo, para um potente entendimento do processo de urbanização, faz-se necessário reconhecer o papel das representações. O material e o simbólico se fundem, tornam-se inseparáveis na produção do espaço. "Como distinguir o discurso, da estratégia, do objetivo e, do resultado obtido?" (Ibid.). Um dos discursos mais potentes para legitimar a reestruturação imobiliária é aquele que se apropria do ideário de catástrofe ambiental que povoa as representações dos indivíduos atualmente.

Alvarez relata uma entrevista em que um líder de uma ocupação antiga, localizada em frente à represa Guarapiranga, fala sobre a remoção de sua comunidade, justificada pela criação de um parque na orla da represa e sobre a impossibilidade de resistir nesse caso: "desta vez não, porque contra o meio ambiente ninguém ganha" (ALVAREZ, 2013, p. 121). O capital soube se apropriar do ambientalismo para realizar seus projetos, afinal, quem é capaz de se colocar contra o meio ambiente? Ainda segundo Alvarez (2013), o discurso da sustentabilidade ambiental como premissa de novos projetos urbanísticos é quase inquestionável.

A reestruturação imobiliária de noroeste nos coloca diante de um paradoxo. Dois de seus principais impulsos são o rodoanel e o planejamento urbano sustentável, que andam juntos e, simultaneamente, propõem preservação ambiental e expansão urbana, conservação de áreas vegetadas e aumento dos acessos rodoviários. Nossa hipótese é que essa contradição se resolve, pois a preservação ambiental não é o objetivo central da reestruturação. Os prejudicados nesse aparentemente contrassenso são as frações mais pobres da classe trabalhadora, que sofrem com a gentrificação e que têm o acesso à terra 
controlado, enquanto outras formas de uso imobiliário são permitidas e estimuladas. Dentre elas, o condomínio "sustentável”, isto é, próximo a áreas verdes.

Esse paradoxo rodoanel-sustentabilidade, que mobiliza a reestruturação espacial, expressa-se na forma como alguns moradores representam esse processo material. Em depoimento, Márcia, moradora do Jardim do Russo e ex-militante da CEB, posicionou-se relutante em relação à possível chegada de empresas de logística ao bairro: "isso pode comprometer o nosso verde, porque dizem que aqui tem um clima muito bom". Nessa fala, pode-se notar a importância simbólica das políticas que vêm concebidas de fora para dentro do bairro: foi um sujeito indeterminado que disse que o clima é bom, não necessariamente é algo sentido por ela. Também há nessa fala uma apropriação pessoal do discurso sobre mudanças climáticas globais.

Romero, em depoimento sobre a disponibilidade sobre a falta de empregos no bairro vai em sentido parecido:

\begin{abstract}
Perus teria que receber algumas empresas e empregos (devido ao aumento populacional), mas não muitas não... umas duas ou três, nada mais que isso não, porque pela vocação do bairro não é legal 20 ou 30 empresas migrarem pra lá, porque vai impactar bastante o meio ambiente e a natureza, que é o que a gente tem de melhor ali. Como é o último bairro da capital, a gente fica ali meio que abandonado, mas curtindo aquela natureza. Daria uma força com os empregos, mas a gente sabe os impactos, principalmente para o meio ambiente.
\end{abstract}

Uma série de inferências pode ser feita a partir dessa resposta que demonstra uma forma de subjetivação da realidade socioespacial de Perus. Deixemos essas interpretações a cargo do leitor. O que queremos destacar aqui é que, aos poucos, podese observar uma cidadania-bloco se constituindo em torno da sustentabilidade nesse bairro periférico.

A narrativa ambientalista do processo social acaba por disputar espaço entre as representações sociais com a ideia de "direito à cidade", ou, até, com a memória de mobilização do bairro de Perus ${ }^{133}$. Como dito, a cidadania-bloco cumpre um papel na reprodução do espaço como negócio imobiliário. No capítulo três, será realizada uma análise mais detalhada do que são alguns dos projetos urbanísticos sustentáveis, em sua relação com o processo de reestruturação imobiliária, a fim de destrinchar que urbanismo é esse. Mas, antes disso, é necessário refletir sobre o ambientalismo e a ascensão de novos negócios verdes.

\footnotetext{
${ }^{133}$ Esse tema será aprofundado no subcapítulo "Os interesses em torno da Fábrica de Cimento e da
} memória do bairro". 


\section{NOTAS SOBRE O AMBIENTALISMO E OS NOVOS NEGÓCIOS "VERDES"}

O presente capítulo apresenta um debate sobre alguns aspectos teóricos da conformação do ambientalismo, da ideia de natureza e dos novos negócios associados eles. Parece-nos necessária essa inflexão para uma compreensão mais completa da inserção do "desenvolvimento sustentável” no processo de reestruturação produtiva. Além disso, se buscaremos desmistificar algumas ideias associadas ao ambientalismo dominante.

\subsection{Apontamentos sobre o conceito de natureza na urbanização da sociedade}

A crítica a que se pretende essa dissertação perpassa, sem dúvida, pela abordagem da ideia de natureza e do seu desdobramento prático: "O que é a natureza? Como reaprendê-la antes da intervenção, antes da presença dos homens e de seus instrumentos devastadores? A natureza, esse mito poderoso, transforma-se em ficção, em utopia negativa (...)" (LEFEBVRE, 2006, cap. 1, p. 36).

Provavelmente Lefebvre, ao escrever esse texto, ainda não tinha ideia do quão potente ia se tornar a expressão "mito poderoso" para definir a natureza, principalmente após o advento da "economia verde", que tem nessa "utopia negativa" um baluarte para uma ampla gama de negócios.

As compreensões contemporâneas sobre a natureza surgem com a emergência do capitalismo industrial. A partir desse momento histórico se conformam conceitualizações de acordo com as condições materiais desse modo de produção. É possível afirmar que não há uma concepção e, sim, concepções sobre o tema, que podem ser separadas em duas, mais gerais.

Um primeiro entendimento da natureza a vê como externa ao ser humano (sociedade), ou seja, se define pela contradição em relação ao que é social. A "natureza natural" (SEABRA, 2003b), uma realidade autônoma à sociedade. Essa, por sua vez, está em busca de compreendê-la e dominá-la, para incorporá-la no processo de produção. Trata-se da natureza vista enquanto "recurso natural", matéria prima, uma expressão do processo de mercantilização da natureza em curso.

A segunda concepção trata o ser humano e, seu comportamento, como sendo naturais, assim como o de qualquer outra espécie. Essa visão internaliza a sociedade: humano e não humano são a natureza. Trata-se, portanto, uma concepção universal. A ciência moderna colabora para essa concepção a partir da compreensão da totalidade 
baseada nos conhecimentos da física, que se desdobram nos preceitos da química e, consequentemente da biologia. Essa universalidade tecida pela ciência desemboca até mesmo em uma "sociobiologia 134 ". Há que se destacar que a concepção universal da natureza, bem anterior a ciência moderna, origina-se em uma compreensão teológica do mundo.

Por mais que essas duas concepções pareçam inconciliáveis, no desenrolar da sociedade capitalista, ambos os entendimentos aparecem sistematicamente misturados e confundidos, sendo, de certa forma, complementares na percepção comum que se tem, atualmente, do conceito de natureza. Para Lefebvre (1969) a unidade possível da definição de natureza é dada, somente, pela confusão e, a ausência de uma estrutura de conceito torna a natureza uma "imagem conceito": "A natureza, na sua confusão, une essas duas determinações. Ela as une apenas na confusão, o que significa que a unidade dessas duas determinações não é completada teoricamente ou praticamente, lúcida e transparente" (Ibid, p. 157).

Mesmo tendo consciência de que Karl Marx não estudou esse conceito diretamente, nos apoiaremos em outros autores que buscaram, através de fragmentos de sua obra, identificar uma concepção de natureza (SMITH, 1988; LEFEBVRE, 1969; SEABRA, 2003b). Marx não partilhava da ideia de natureza como exteriorizada, ou seja, de uma dualidade entre sociedade e natureza. Tampouco, sua visão se assemelhava a uma concepção universalizante de natureza que abrangesse o ser humano de um ponto de vista biológico do processo social, segundo a qual a "natureza humana é simplesmente um subconjunto da natureza biológica" (SMITH, 1988, p. 34). É possível afirmar, a partir dos comentadores de Marx, que há sim uma unidade entre sociedade e natureza, mas que parte de uma prioridade social, visto que o conceito de natureza surge da história humana e é, cada vez mais incorporado socialmente. Ou seja, é a partir de uma perspectiva histórico social que se pode refletir sobre a ideia de natureza. Diante dessa perspectiva Smith se esforça em propor uma base teórica marxista para esse conceito, através da ideia de produção da natureza (1988). Segundo essa teoria:

Tão logo os seres humanos se separaram dos animais, começando a produzir seus próprios meios de subsistência, eles começaram a mover-se mais e mais próximos ao centro da natureza. Através do trabalho humano e da produção da natureza na escala global, a sociedade humana colocou-se no centro da natureza (Ibid., p.107).

\footnotetext{
${ }^{134}$ As concepções universais e externas da natureza podem assumir diferentes aparências e conter várias nuances. Para uma análise mais detalhada sobre o tema ver Smith, 1988, capítulo 1.
} 
Ao transformar suas forças essenciais em forças produtivas que se apropriam universalmente da natureza - uma apropriação física e também espiritual ${ }^{135}$ (objetiva e subjetiva) -, o ser humano pode criar um mundo para-si. Esse ato histórico faz com que a natureza se torne histórica e social (...) o que não implica dizer que a natureza só exista em função do ser humano, mas que ele a transforma ao objetivar suas forças para satisfazer suas necessidades - "do estômago ou da fantasia" - e, com isso, atribui historicidade a ela (FARIA, 2017, p. 14).

Através do desenvolvimento das forças produtivas o ser humano é capaz de criar suas próprias condições de "natureza", por isso a ideia de produção da natureza. Isto é, observado através do desenvolvimento histórico, o substrato natural aparece cada vez mais como sendo socialmente produzido. A produção da natureza se torna a base de todo o mundo sensitivo como agora existe (SMITH, 1988). Mesmo para espaços que estão em nosso imaginário como "totalmente naturais" existem estudos que comprovam a decisiva influência histórica social na conformação de sua paisagem, como por exemplo, a floresta amazônica interpretada como uma floresta culturalmente produzida (FURLAN, 2006). Cada vez tem menos sentido a cisão conceitual do espaço entre "natural" e "produzido", ainda mais diante do modo de produção capitalista:

A provisão social de sustento sempre envolveu uma certa "produção da natureza". Nas sociedades capitalistas, entretanto, a produção da natureza muda de uma realidade incidental e fragmentada para uma condição sistêmica de existência social, de uma singularidade local para uma ambição global. (SMITH, 2006, p. 23, tradução nossa)

Não se trata, entretanto, de um completo e racional controle da natureza, pois nem tudo cabe dentro da lógica de produção e, nem essa lógica se mostra racional quanto às suas consequências, pelo contrário. Dito de outra maneira, a existência de eventos naturais extremos e incontroláveis impedem o ser humano de ser absoluto na produção da natureza $a^{136}$. Além disso, a própria irracionalidade do processo capitalista impossibilita a dominação da completa produção da natureza, através de ocorrência de fatos indesejáveis e destrutivos como, por exemplo, a emissão de poluentes atmosféricos, ou a escassez de água potável ${ }^{137}$.

Portanto, a partir da noção de produção da natureza, a ideia de natureza externa é conceitualmente incoerente, já que impossibilita a compreensão do lugar

\footnotetext{
${ }^{135}$ A apropriação da natureza por e para o humano é simultaneamente a apropriação do humano de sua própria natureza humana (interior). Ao produzir o mundo exterior, o ser humana recria (produz) a si próprio (LEFEBVRE, 1969).

136 "Se vivemos agora em meio à "natureza social", isso não nega de maneira alguma o poder ou a existência de processos "naturais". Gravidade, processo biológico, químico e a mudança geológica não podem ser sumariamente suspensas, e de modo algum devem suas origens ou operação contínua ao trabalho social, por mais que seus efeitos possam, de várias formas limitadas, ser revogadas, alteradas, reencaminhadas ou projetadas diferentemente" (SMITH, 2006, p. 23, tradução nossa)

${ }^{137}$ Para conhecer uma descrição detalhada sobre a gênese e desenvolvimento do conceito de Produção da natureza, ver Cornetta (2017), capítulo 2.
} 
humanidade e da historicidade na natureza. Esse problema conceitual se desdobra, pois a partir dele, os problemas reais são interpretados de forma fragmentada, o que, segundo o Cornetta, torna essa concepção "politicamente problemática porque traduzido em problemas ambientais, passíveis de serem solucionados tecnicamente, tiram o foco da história eliminando a possibilidade de um entendimento social e das relações políticas que moldam o ambiente.” (2010, p. 133) Inversamente, é eficaz a ideia de natureza natural, enquanto fetiche do natural/natureza, obscurecendo os fundamentos sociais de sua produção. Trata-se da realidade problemática da fetichização.

Da mesma forma que é ineficaz pensar uma dualidade entre sociedade e natureza, coloca-se a necessidade de rejeitar uma "biologização/naturalização" do processo social, que pode se desdobrar da concepção universal. Há que se ter consciência da natureza social do mundo que vivemos ${ }^{138}$ (SEABRA, 2003b). Ou seja, diante da confusão da imagem conceito natureza dispersada nas representações sociais, nos parece necessário enfatizar a negação de uma concepção universal de natureza, ancorada na biologia, visto que ela se desdobra em uma naturalização do processo social, que é ideológica pois acaba por mascarar certos comportamentos e legitimar injustiças sociais, como se fossem fenômenos naturais: "A competição, o lucro, a guerra, a propriedade privada, o erotismo, o heterossexualismo, o racismo, a existência de ricos e de despossuídos (...) tudo isso é considerado natural” (SMITH, 1988, p. 46).

A partir dessa breve exposição, cabe-nos pensar sobre como a imagem conceito de natureza se desdobra no atual processo de urbanização - dada a importância do aspecto simbólico para a produção do espaço. No imaginário social predomina uma visão que oscila entre universal e externa e que mescla uma visão científica com uma visão romântica da natureza. Essa última passou a ter relevância na medida em que a natureza deixou de ser ameaçadora e se tornou "domada", ao longo do processo de modernização. A crescente urbanização da população levou os sujeitos a viverem suas experiências sensíveis diante da segunda natureza ${ }^{139}$, da grande cidade, sendo pautados pelo tempo abstrato da produção. Essa experiência, nem sempre agradável - porque opressora -, criou a carência social romantizada de uma "paisagem natural intocada". Do ponto de vista do cidadão urbano, o "espaço natural" deixa de ser algo ameaçador ao

\footnotetext{
138 “(...) alguém digita o interruptor não precisa ter a menor idéia de que está tendo uma relação com um rio ou outra força objetivada do mundo. E assim que acontece a relação simbiótica entre natureza e sociedade. A natureza participa de nossa vida em fragmentos, como obra humana. Isto define uma natureza social do mundo" (SEABRA , 1995, apud TOMÁS, 1996 :174).

${ }^{139}$ A estrutura mercantil das coisas aparece como "lei natural". A sociedade torna-se, assim, a realidade do homem, torna-se Segunda Natureza (LUKÁCS, 2003).
} 
ser humano e se torna algo belo, lúdico, poético. Algo para ser contemplado. Esse tipo de visão sobre a natureza surge exatamente dos habitantes da cidade, distanciados do que seria a natureza natural. O que de certa forma, expressa o mal estar do espaço urbano industrial, através de uma projeção do que poderia ser o seu outro.

Desse modo, segundo Smith (1988), o movimento de louvação e de "volta à natureza" ganha força - já no fim do século XIX (nos EUA) - especificamente entre os habitantes urbanos. Inicialmente, esse movimento aparece como uma necessidade da classe média, mas progressivamente se difunde para as classes mais pobres - pelo menos enquanto representação, pois não necessariamente se realiza na prática. Essa noção se difundiu tanto nos últimos anos, a ponto de se apresentar "em termos de novos valores envoltos em misticismos diversos, quase sempre relacionados à pregação de retorno ao natural como se fosse possível pensar e atuar com uma natureza primeira." (SEABRA, 2013, p. 3) De certa forma, se trata de uma busca, momentânea, de "fuga" da lógica social do tempo-espaço abstrato da cidade capitalista. Da incompletude que a vida urbana gera se desdobram novas necessidades que - eventualmente - são remediadas pela possibilidade do consumo de mercadorias "naturais". Observa-se que o "tempo livre" também se torna meio de reprodução das relações sociais de produção e do próprio capital.

Gozar férias no interior bruto tornou-se moda, especialmente depois que a fotografia permitiu a representação realista da paisagem (...) Nessas atividades e na onipresente "fuga" da cidade nos fins de semana, a visão de natureza inerente ao movimento de "volta à natureza" encontra sua expressão contemporânea (SMITH, 1988, p. 38)

A grande indústria se encarrega de oferecer produtos concernentes a essa representação da natureza. Destaca-se, especialmente, uma aproximação entre a ideologia de "volta à natureza" e a colonização dos tempos "livres", que desemboca em uma atitude visual e contemplativa perante espaços que simulam uma suposta "paisagem natural intocada" (SANTANA, 1999).

Através dessa concepção de natureza externa e bela, se constitui um discurso que justifica, simbolicamente, a reestruturação espacial das cidades. Se propõe na própria área urbana "simulacros de natureza": tentativas pontuais de se reatar relações harmoniosas com a natureza, "perdidas" no cotidiano urbano ${ }^{140}$.

\footnotetext{
140 Nesse sentido, há uma tendência a "museificação" e espetacularização do lugar "natural", transformando esse espaço em cenário e escondendo as relações sociais ali existentes no presente ou no passado. Casos como esses são muito comuns no chamado ecoturismo. Também podemos pensar assim sobre o Parque Anhanguera e os eucaliptais de entorno, antigos locais de silvicultura, cuja paisagem foi produzida através dos trabalhos dos lenheiros. Esses que inclusive participaram da histórica greve de
} 
$\mathrm{Na}$ experiência urbana a natureza aparece como o "outro", uma exterioridade que pode ser compensada no "tempo livre": "A exterioridade é substituída pela universalidade, pelo menos no fim de semana" (SMITH, 1988). A "busca pela natureza perdida" como algo aparentemente diferente do urbano se caracteriza por ser um desligamento temporário do ritmo do trabalho, uma espécie de "fuga" e também de crítica ao cotidiano. No entanto, já é fato notório que o lazer e o turismo se configuram como uma forma de colonização do tempo de ócio, de modo que a "fuga" do trabalho acaba por se constituir somente no nível das aparências, visto que há uma reiteração das relações sociais de produção durante o "tempo livre" em contato com o que se crê "espaço natural”.

Dada as condições de uma sociedade urbana industrial, os elementos "naturais" são transformados em necessidades históricas e sociais (novas raridades), entretanto, esses são na verdade uma nova mediação para a produção, repartição e distribuição de riqueza.

“A volta à natureza" é, portanto, uma nova vertente da visão universal da natureza, que se constitui a partir do simulacro de movimento da exterioridade em busca da universalidade. É uma tentativa de resposta à objetivação da natureza dada pelo progresso industrial, que se apega a misticismos e simbolismos para uma possível conciliação com o cosmos perdido. Essa concepção imprecisa se aproxima mais da universalidade teológica do que da científica (biológica). Sua consumação se dá através da forma mercadoria, pelo "espetáculo" (DEBORD, 1997) re-união sociedade natureza, que ocorre pela justaposição lado a lado do humano e do "natural", pelo consumo visual daquilo que se crê natureza, pela compra de mercadorias verdes... A imagem conceito de natureza é preenchida por simbolismos diversos, que acabam reproduzindo as relações sociais de produção ${ }^{141}$. “O cotidiano é percorrido à maneira do imaginário e o imaginário distingue-se pouco do cotidiano. Mistura informe, que se crê natureza ou volta à grande Natureza" (LEFEBVRE, 1969, p. 181).

1962 da CBCPP e acabaram demitidos pelo "mau patrão", que nunca os havia registrado formalmente (JESUS, 1992).

141 "Tudo passa a ser "meio ambiente", não só a feiura, a sujeira, o barulho, como também os estados psicofisiológicos possivelmente resultantes, tais como a fadiga ou a enfermidade (particularmente as enfermidades psicossomáticas). É preciso escapar a esse quadro, e escapar significa ingressar num novo sistema de consumo: o consumo dos lazeres no campo ou na montanha, consumo de "clorofila", consumo de cores (e arrasamento dos velhos imóveis" (GEORGE, 1973: 8-9). 
Tendo em vista essa breve reflexão sobre a imagem conceito de natureza na sociedade urbano industrial, se buscará contextualizar como se formou o atual ramo de negócios verdes a partir da distorção e desvio do movimento ambientalista.

\subsection{A decomposicão do ambientalismo: da contestacão à ideologia e ao mercado}

A partir das últimas décadas do século $\mathrm{XX}$ se constituiu o que podemos chamar de uma filosofia ambientalista. Não se trata de algo sistematicamente formalizado e nem coerente. No entanto, é algo que vem se configurando como forma de pensamento, traduzida em novos valores e práticas. Sua origem se refere aos movimentos sociais que denunciavam distintos problemas ecológicos. É possível afirmar, no entanto, que a filosofia ambientalista dominante atualmente não exprime de forma coerente os princípios desses primeiros movimentos contestatórios dos anos sessenta.

Verifica-se hoje em dia uma autonomização do "verde" enquanto representação social de nosso tempo. Segundo Seabra (2013), o "verde" - mais ainda que o ambientalismo - se torna um valor social: "uma filosofia de nossa época, capaz de estruturar o pensamento, de moldar percepções do mundo e condutas, claro que convertida numa ideologia capaz de encobrir a essência" (Idem, p. 17).

Na década de 1960 irrompe uma série de reivindicações populares pelo mundo, inclusive aquelas que apontavam problemas ambientais. As manifestações da contracultura desse período continham diferentes expoentes ${ }^{142}$ do que veio a ser chamado, posteriormente, de "questão ambiental". De forma subsequente, essa questão também passou a ser debatida no âmbito político e econômico internacional, de onde se desdobraram uma série de relatórios, estudos, reuniões etc.

Era (e ainda é) patente que os séculos de reprodução da sociedade produtora de mercadorias implicaram na devastação de espaços, na expropriação de sociedades, na produção de resíduos, na poluição do ar, das águas etc. e resultaram em inegáveis problemas ambientais. A lógica inconsequente de valorização do valor é causadora desses distúrbios que destroem e ameaçam a saúde humana e as próprias condições de reprodução da sociedade.

Diante desse fato, o ambientalismo surgiu como uma tentativa de contraposição a esse processo. Entretanto, é notável que, atualmente, a prática ambientalista

\footnotetext{
${ }^{142}$ Sob chancela da questão ambiental vimos ascender lutas que se posicionam em relação a uma ampla gama de causas, como: extinção de espécies, desmatamento, poluição de água e ar, ameaça nuclear, uso de agrotóxicos, urbanização desenfreada, entre muitas outras (PORTO-GONÇALVES, 1996: 12).
} 
dominante tem se demonstrado incapaz de resolver as contradições socioambientais e, ainda mais, tem sido reprodutora da segregação social (PORTO-GONÇALVES 2013, p. 317). Faz-se necessário, então, problematizar como esse movimento contestador foi transformado em um discurso publicitário e em uma prática segregadora.

O movimento ecológico se constituiu através de contradições políticas internas. Estava em jogo uma disputa de narrativas sobre o tema. De um lado constituiu-se uma interpretação "ecossocialista" sobre a degradação ambiental, originária da raiz contestadora do ambientalismo, que buscava representar uma radicalidade frente à racionalidade econômica ${ }^{143}$ :
(os ecossocialistas) denunciam as causas da degradação ambiental e da pobreza como sendo consequências do modo de produção capitalista e, de seus mecanismos excludentes: o sistema de mercado, a globalização perversa e o consumismo alienante. Portanto, a pobreza não seria a causa da degradação ambiental como querem fazer crer os ecocapitalistas. (RIBEIRO et al., 1992, p. 98)

No outro lado do espectro ideológico, a burguesia internacional, organizada através do Clube de Roma ${ }^{144}$, voltou-se para um discurso neomalthusiano ${ }^{145}$ sobre a questão, consagrado pela publicação best seller "Os Limites do Crescimento" (MEADOWS et al., 1972). Baseado em modelos matemáticos computadorizados, esse documento afirma que o crescimento populacional mundial, realizado em progressão geométrica, entraria em contradição com os recursos naturais limitados do planeta, e previu uma catástrofe em breve. Para que isso não ocorresse o texto propunha $\mathrm{o}$ "Crescimento Zero": controlar o crescimento populacional, sobretudo nos países periféricos ("terceiro mundo"), que apresentavam as taxas mais altas de incremento demográfico.

Nota-se que o problema da superpopulação - debatido desde o século XVIII passou a ser interpretado através do prisma do superconsumo: a demanda por recursos naturais da sociedade seria matematicamente desproporcional à capacidade desses recursos se reproduzirem. É a partir desse argumento que se assenta toda retórica da sustentabilidade ambiental. Políticas ambientalistas seriam uma forma de reequilibrar

\footnotetext{
143 Michael Löwy é um dos principais expoentes desse movimento nos dias de hoje. Segundo sua interpretação é necessário encontrar um caminho comum entre ecologia e o socialismo. Afastando o primeiro das soluções mercadológicas e da lógica do lucro e o segundo do produtivismo. Para mais informações sobre essa proposta ver Löwy, M. O que é o Eco-socialismo? disponível em < http://www.arturbruno.com.br/blog/?id=2404 > Acessado em: 11 de agosto de 2017.

144 Organização internacional, criada em 1968, formada por industriais, economistas, cientistas e altos funcionários governamentais, cujo objetivo é promover a compreensão dos desafios globais da humanidade. Retirado de < http://www.clubofrome.org > Acessado em: 29 de setembro de 2017. ${ }^{145}$ Um debate acerca do malthusianismo e neomalthusianismo será realizado no subcapítulo 4.4.
} 
esse descompasso entre sociedade e natureza. Segundo o relatório Os Limites do Crescimento a via seria o controle populacional, que regularia o controle do consumo.

É fundamental localizar que a publicação de Os Limites do Crescimento - assim como a irrupção do ambientalismo conservador e/ou de mercado - ocorre de maneira concomitante à ascensão das ideias neoliberais. Um momento em que se buscava remediar a grave crise de valorização do valor que se manifestava e que levou o capital a buscar meios de garantir a reprodução de seus fundamentos econômicos sociais.

Após os chamados "trinta anos de ouro" do capitalismo, se iniciava o desmonte do modelo Keyneisiano de desenvolvimento, considerado esgotado. Para Seabra (2013, p.1), a publicação Os Limites do Crescimento foi uma forma de traduzir a crise de reprodução capitalista como sendo uma crise ambiental. Segundo a autora essa manobra ideológica serviu como um dos alicerces para a instauração das políticas neoliberais, já que a crise ambiental endossava a ideia de crise do Estado de Bem Estar Social, legitimando seu desmonte ${ }^{146}$. Dessa forma, o ambientalismo se tornava parte integrante do processo de reestruturação produtiva.

No entanto, o controle populacional dos mais pobres como meio de enfrentamento da crise ambiental recebeu críticas de distintos campos do espectro político ambientalista. Faria explica que parte das críticas ressaltava que era importante:

(...) politizar o "debate matemático", mostrando que a questão não seria apenas numérica, mas distribucional, já que uma pequena parte da população mundial situada nos países mais industrializados era responsável por consumir a maior parte de vários recursos naturais do planeta e por gerar grande quantidade de poluentes. (FARIA, 2017, p. 1)

Com o passar do tempo, o movimento ecológico dominante foi sendo lapidado. A partir de 1987, começou a adquirir sua face mais difundida atualmente, a de “desenvolvimento sustentável”. Nesse ano foi lançado o relatório Nosso Futuro Comum, elaborado pela Comissão Mundial sobre Meio Ambiente e Desenvolvimento - ligada a ONU. Aí está contida uma das definições mais difundidas de "desenvolvimento sustentável”: “(...) aquele que atende às necessidades do presente sem comprometer a possibilidade de as gerações futuras atenderem as suas próprias necessidades" (CMMAD, 1988, p.46). Essa ideia, marcante por sua imprecisão, buscou ser uma alternativa à proposta de "Crescimento Zero" sem, todavia, negar completamente o

\footnotetext{
${ }^{146}$ É possível afirmar que a teoria neoliberal é tributária do malthusismo, visto que acredita em níveis de desemprego e desigualdade social "saudáveis" à sociedade, além de pregar a diminuição drástica dos investimentos sociais do Estado, o que, de certa forma, é um meio de controle populacional. Um debate mais aprofundado sobre as reminiscências do malthusianismo no ambientalismo será realizado no subcapítulo 4.4.
} 
documento do Clube de Roma.

O "desenvolvimento sustentável" buscou se colocar como um caminho afastado de posições extremas, tanto a neomalthusianiana quanto a crítica ao capital ${ }^{147}$. Essa posição política - aparentemente - não bem definida reverbera também em uma indefinição conceitual: não é possível qualificar o que é o "desenvolvimento sustentável ${ }^{148}$ ", pois sua definição é imprecisa e, acima de tudo, maleável.

O conceito de desenvolvimento sustentável serve a interesses diversos. De nova ética do comportamento humano, passando pela proposição de uma revolução ambiental, até ser considerado um mecanismo de ajuste da sociedade capitalista (capitalismo soft), o desenvolvimento sustentável tornou-se um discurso promovido por organizações internacionais, empresários e políticos (...) (RIBEIRO W.C., 2004, p. 63).

Apesar das distorções possíveis (e convenientes) tratemos de encontrar o que há de traço comum quando se fala de "desenvolvimento sustentável". A "sustentabilidade" econômica e ambiental constitui-se como um novo ideário do progresso capitalista. Há uma mobilização intensa do empresariado em torno desse preceito, balizado pelo relatório Nosso Futuro Comum, que preconiza o sucesso dos negócios através de três pilares: ser ambientalmente apropriado, socialmente justo e economicamente viável.

Logo, o "desenvolvimento sustentável" aponta para a possibilidade de uma resolução do suposto conflito "sociedade x natureza ${ }^{149 ", ~ a ~ p a r t i r ~ d a ~ h i p o ́ t e s e ~ d e ~ q u e ~ e ́ ~}$ possível conformar um sistema orgânico, equilibrado, dentro de uma lógica industrial de mercado. Para tanto, seria necessário controlar desperdícios e estabelecer políticas mitigadoras, através de um sistema de quantificação e precificação dos chamados "custos ambientais", que se tornam mercadorias ${ }^{150}$. Assim os empresários buscariam realizar a produção através de um processo menos agressivo aos recursos naturais do planeta, sem, no entanto, diminuir sua margem de lucro. Nesse sentido,

\footnotetext{
147 A consolidação do ambientalismo de mercado ocorre simultaneamente à perda de espaço da abordagem contestadora e ecossocialista na disputa de narrativa sobre a crise ecológica. Trata-se de uma vitória ideológica do capital e, ao mesmo tempo, uma abertura de um novo e importante mercado.

${ }^{148} \mathrm{O}$ uso de aspas para designar o termo "desenvolvimento sustentável" é para destacar que, embora seja apresentado como um conceito, não há características suficientes para defini-lo como tal, de modo que se trata de uma ideologia, que existe, portanto, somente enquanto representação. As aspas buscam enfatizar que ao usarmos essas duas palavras estamos expressando um pseudoconceito. Nesse sentido, estamos em concordância com a formulação de Rodrigues: "O termo "desenvolvimento sustentável" não é um conceito, mas uma ideia que pretende encontrar soluções para problemas de esgotamento, poluição das riquezas naturais, num futuro... Ideia genérica que abstrai a realidade, oculta a complexidade, a reflexividade do modo de produção de mercadorias, cria uma espessa cortina de fumaça sobre a apropriação dos territórios, a existência de classes sociais, dificulta a análise crítica." (RODRIGUES, 2005: 93).

${ }^{149}$ Sendo a natureza nesse caso não um conceito, no máximo uma imagem conceito, aproximando-se mais de uma confusão conceitual, como já mencionado anteriormente.

${ }^{150}$ Essa ideia será melhor desenvolvida no próximo subitem, através do exemplo da precificação da atmosfera.
} 
"sustentabilidade" significaria um negócio lucrativo aliado a uma busca de mitigação da destruição ambiental.

Contraditoriamente, o "desenvolvimento sustentável” acabou criando um nível de degradação ambiental considerado "aceitável", definido de acordo com o mercado: se for possível aliar lucros e "compensação ambiental", então a burguesia se engaja no "desenvolvimento sustentável"; caso contrário, se os lucros das empresas estão ameaçados, então a deterioração ecológica é cabível. Dessa forma, o "desenvolvimento sustentável" praticamente delega ao mercado financeiro decidir o como deve ser a política ambiental. Decisão que é tomada de acordo com as possibilidades de ganho ${ }^{151}$. Nossa hipótese é que "desenvolvimento sustentável" tem como objetivo primordial a abertura de novos mercados e não um compromisso ecológico.

(o capitalismo verde) Se converteu, nada mais nada menos, que na maior estratégia para a mercantilização, comercialização e financerização ecológica, o que intensifica e aprofunda radicalmente a penetração do capital na natureza. (SMITH, 2006, p. 17, tradução nossa)

Evidencia-se o limite "desenvolvimento sustentável": o não questionamento da lógica capitalista de produção, que tem como elemento essencial a busca de lucro e o aumento constante da produtividade. A aposta de que os valores éticos sustentáveis podem regular a avidez do capital nos parece uma distopia.

No entanto, nos interessa notar que esse discurso, oriundo do mundo empresarial, se autonomiza e passa povoar o imaginário social de uma maneira disforme, de modo que, a própria sociedade é condicionada a operá-lo, a sua maneira (SEABRA, 2013). A "sustentabilidade", ao mesmo tempo em que se configura como uma estratégia empresarial, é imposta à sociedade, convocando - especialmente através da publicidade - cada indivíduo para enfrentamento do desgaste da natureza. O incentivo a uma prática cotidiana "sustentável" e ao "consumo consciente" acabam culpabilizando os indivíduos pelo desgaste do planeta. Esse peso desmedido sobre os indivíduos desconsidera as contradições do processo capitalista e as diferentes inserções de classes sociais ${ }^{152}$. No capítulo 4 descreveremos como essa "culpabilização" acaba recaindo com mais peso sobre as classes proletarizadas.

O que a ideologia ambientalista logra é estabelecer um reconhecimento social da crise como sendo exclusivamente ambiental: uma má regulação da relação das práticas individuais com a natureza. Isso ocorre ao passo que se desvia o foco dos

\footnotetext{
${ }^{151}$ No próximo subtítulo esse tema será mais aprofundado.

152 Rodrigues (2005) afirma que o discurso ambiental autonomizado tem a potência ideológica de ocultar a existência de classes sociais e, simultaneamente, criar um suposto conflito entre gerações.
} 
fundamentos econômicos, sociais e políticos do momento crítico. "Há uma exaltação da natureza e do natural, preenchendo o vazio de projetos políticos de superação de inúmeras crises sociais. A potência ideológica do ambiental, substituindo o caos sócioespacial é extremamente paradoxal (...).” (Damiani, 2008, p. 247) Difunde-se uma espécie de conformismo diante das mazelas da sociedade, ao se crer que é possível alcançar princípios éticos na lógica capitalista. Não se problematiza o fato de que o desgaste da natureza é intrínseco aos fundamentos desse modo de produção. Se estabelece, portanto, um consenso social reformista para a crise capitalista. Debord (2015) destacou o fracasso garantido desse reformismo e que ele pode levar ao fim da sociedade:

Depois do fracasso fundamental de todos os reformismos do passado - que, todos, aspiravam à solução definitiva do problema das classes -, um novo reformismo se esboça, obedecendo às mesmas necessidades que os precedentes: lubrificar a máquina e abrir novas ocasiões de lucro às empresas de ponta. O setor mais moderno da indústria se lança sobre os diferentes paliativos da poluição, como sobre uma nova saída, tanto mais rentável quanto mais uma boa parte do capital monopolizado pelo Estado é nela empregada e manobrada. Mas se este novo reformismo tem logo de saída a garantia de seu fracasso, exatamente pelas mesmas razões que os reformismos passados, ele mantém com eles a diferença radical de que não tem mais tempo diante de si.

O ambietalismo reformista é difundido socialmente através do discurso de tecnocratas e cientistas, que têm papel central na conformação dessa ideologia. PortoGonçalves questiona o ambientalismo irrefletido desses sujeitos:

(...) não passa pela cabeça de certos ecologistas (agentes do movimento ambientalista), que as relações sociais não são naturais. Aliás, este é outro recurso das ideologias de dominação, que procuram aparecer como naturais, silenciando sobre a historicidade dos fenômenos. Sabemos o preço que já tivemos que pagar por essas ideologias naturalizantes (o racismo e o fascismo, por exemplo). (1984, p. 33, apud, SEABRA 2013, p. 4)

Notamos, portanto, uma rápida esterilização e inversão do caráter contestatório do ambientalismo dos anos 1960 que foi transformado em uma nova fonte de capitalização e em uma ideologia conservadora. Desviando um conceito situacionista podemos afirmar que houve uma "decomposição ${ }^{153}$ " do ambientalismo. Seu caráter revolucionário foi cooptado, fragmentando, de modo que o ambientalismo tornou-se uma representação de si mesmo, “espetacularizado ${ }^{154 "}$ passível de diversas

\footnotetext{
${ }^{153}$ Conceito criado pela Internacional Letrista/Situacionista para descrever um processo cultural que tornou adestradas e lucrativas as inovações subversivas das vanguardas artísticas europeias do começo do século XX. Esse conceito foi expandido para outras dimensões da vida cotidiana, como é o caso das descobertas científicas que apresentam algum tipo de questionamento à reprodução social e que, rapidamente são banalizadas, tornadas inofensivas e confusas, colocadas nas prateleiras como outra mercadoria qualquer. O processo de decomposição, sem dúvida, foi uma das grandes criações ideológicas da burguesia. (Gonçalves, 2013)

154 “Quando o mundo real se transforma em simples imagens, as simples imagens tornam-se seres reais e
} 
interpretações, que levaram, inclusive, suas reivindicações a transformem-se em mercadorias ${ }^{155}$.

Assim o ambientalismo se estabelece enquanto doutrina capaz de balizar as formas de pensar. Nesse sentido, a publicidade é de suma importância para constituir uma cidadania-bloco e esterilizar qualquer contestação que o ambientalismo poderia representar. A crise ecológica é notável aos olhos de qualquer um, de modo que a indignação que isso poderia representar é direcionada e banalizada pelo tempo vazio do “consumo consciente" de mercadorias com "selo verde". Há uma fusão entre o discurso publicitário e o ambientalista que medeia a criação de uma nova necessidade social de consumo. Por essa via a questão ecológica penetrou à sociedade e tornou-se uma potente ideologia ${ }^{156}$.

(...) é fácil sensibilizar este público lançando alguns brados de alarme e respeito ao destino reservado ao meio ambiente. A defesa deste (...) faz hoje parte do repertório político eleitoral. Dentro desta mesma ordem de ideias, esta defesa constitui uma excelente plataforma publicitária para o lançamento de diversas operações especulativas, tanto no campo da valorização de terrenos como nas campanhas preparatórias de vendas maciças de novos produtos industriais considerados isentos de efeitos nocivos sobre o meio ambiente. (GEORGE, 1973, p. 121)

Assim, o chamado "neoliberalismo ambiental" (PORTO-GONÇALVES, 2013) se espalha pelo planeta através da globalização capitaneada por instituições supranacionais, como o Banco Mundial e a ONU, por exemplo, que tem papel central no processo de difusão da ecologia de mercado. Através de discursos e regras internacionais se cria uma base mundial para os negócios "sustentáveis". "O Banco Mundial (...) passou a exercer um papel fundamental na construção do desenho de uma ordem ambiental neoliberal” (Ibid., p. 306). Diversas recomendações desse Banco, a

motivações eficientes de um comportamento hipnótico. O espetáculo, como tendência a fazer ver (por diferentes mediações especializadas) o mundo que já não se pode tocar diretamente, serve-se da visão como o sentido privilegiado da pessoa humana - o que em outras épocas fora o tato; o sentido mais abstrato e mais sujeito à mistificação corresponde à abstração generalizada da sociedade atual. Mas o espetáculo não pode ser identificado pelo simples olhar, mesmo que este esteja acoplado à escuta. Ele escapa à atividade do homem, à reconsideração e à correção de sua obra. É o contrário do diálogo. Sempre que haja representação independente, o espetáculo se reconstitui”. (DEBORD, 1997, p. 18, destaque do autor)

155 "A partir das décadas de 1980 e 1990, uma extraordinária gama de novas "mercadorias ecológicas" entrou em operação. Ironicamente, elas devem sua existência, primeiro e acima de tudo, para o sucesso do movimento ambiental nas décadas de 1960 e 1970.” (SMITH, 2006, p. 17 - tradução nossa)

${ }^{156}$ Por outro viés, a ideologia sustentável reafirma os ataques à classe trabalhadora: através do marketing das empresas "ecologicamente correta", do "selo verde", que acoberta uma série de problemas relativos à flexibilização da questão trabalhista. Também a questão do direito à cidade acaba sendo eclipsada pelo ambientalismo como analisaremos mais adiante. 
partir da década de setenta, passaram a proclamar os limites da natureza e indicar formas de "desenvolvimento sustentável"157.

A formulação de que a ascensão da "sustentabilidade" é parte de uma reação à crise capitalista foi reiterada pela ONU, após a crise financeira de 2008, quando essa instituição intensificou sua atuação no sentido de retomar o crescimento econômico global, através da "Iniciativa Economia Verde", elaborada pelo Programa das Nações Unidas para o Meio Ambiente (PNUMA) e que buscava promover a difusão de negócios "ecologicamente saudáveis" através de uma série de ações ${ }^{158}$.

Também a ONU, nos anos noventa, lançou o "Cidades Sustentáveis", outro exemplo de recomendação de práticas do "neoliberalismo ambiental”, que fundamentará os parâmetros do urbanismo sustentável.

Seabra chamou essa atuação influenciadora dos órgãos supranacionais de hiperpolítica $(2003 ;$ 2004), uma derivação neoliberal do que outrora fora o imperialismo, que ocorre sob a "forma de empréstimos, apoios e investimentos conforme as regras desta ordem internacional" (SEABRA, 2003b, p. 320).

A hiperpolítica, enquanto política de nível global, se adéqua às especificidades locais/regionais e opera na base da sociedade de forma fragmentária, através de projetos específicos (SEABRA, 2003b). Esse fato pode ser notado no caso dos créditos de carbono de Perus, onde uma nova "mercadoria verde" foi introduzida através de ações de instituições financeiras e agentes da hiperpolítica, que conseguiram viabilizar um projeto sustentável na periferia paulistana e, assim, dar vazão para uma série de capitais voláteis internacionais.

Resumindo a ideia desse subcapítulo, podemos afirmar que o atual ambientalismo se caracteriza por um papel simbólico (como ideologia) e material (como um novo ramo de negócios) no processo de reestruturação produtiva mundial.

Não é possível, no entanto, simplesmente afirmar que o ambientalismo é uma visão errada. Como uma ideologia, se trata de uma visão distorcida do mundo, originada de uma perspectiva de classe específica. Evidentemente os problemas ambientais são gravíssimos e da maior importância. Não se busca negar esses dilemas, o que se pretende nessa dissertação é observar as consequências atuais do ambientalismo de mercado, que se autonomizou de suas bases originais. A crise ambiental tornada uma representação de si mesma gera uma confusão, que impede uma simples distinção do

\footnotetext{
${ }^{157}$ No item 2.4 é possível ver um momento específico da ação desse banco em torno da sustentabilidade.

${ }^{158}$ Para saber mais detalhes sobre essa ação ver Faria (2017).
} 
que é um problema ambiental grave e do que é mera publicidade: "Seria uma leviandade inqualificável considerar o interesse atribuído aos diversos problemas do meio ambiente como uma simples moda ou como distração ou artifício publicitário. Não nos enganemos, entretanto" (GEORGE, 1973, p. 125).

Enquanto um novo ramo de negócios, componente da reestruturação produtiva, analisaremos o "desenvolvimento sustentável" em dois segmentos distintos pelos quais ele se projeta sobre bairro de Perus: a precificação da atmosfera (os créditos de carbono) e o urbanismo sustentável.

\subsection{Os novos negócios "verdes": o processo de abstracão do ar}

É notável que a realidade social tem se tornado gradativamente mais obscura. A raiz social dos fenômenos parece cada vez mais abstrata e complexa. Tomemos como exemplo o surgimento dessa nova mercadoria, o crédito de carbono. Se nos distanciamos do fenômeno para análise notamos que, em um determinado momento da sua história, por alguma determinação, a humanidade resolveu atribuir valor monetário à composição molecular da atmosfera do planeta Terra. $\mathrm{O}$ conceito de valor - como demonstrado por Marx (1985) -, por si só, já representa uma grande abstração, visto que a partir dele se igualiza coisas totalmente diferentes. Essa abstração se faz real, visto que a forma mercadoria é elementar para a organização social.

A expansão da mercantilização da natureza e a consequente quantificação dos elementos naturais, através do valor, também é um dos fatores de aumento de complexidade para a compreensão do real. Somadas às ideologias, as abstrações progressivamente organizam a sociedade de modo que a compreensão da realidade se torna cada vez mais enigmática. A movimentação dinheraria dos novos negócios verdes e suas consequências desafiam o entendimento do cidadão comum, como no caso dos créditos de carbono de Perus, por exemplo.

Quais são as determinações sociais que fazem com que a tonelada de carbono não-emitida na atmosfera tenha o preço de 19,20 euros? O que justifica que a mesma tonelada de carbono não-emitida seja vendida por 3,30 euros, após quatro anos? Não é o objetivo desse nosso trabalho avaliar quais são as variáveis específicas que influem na conformação do preço de uma Redução Certificada de Emissões (RCE). Contudo, para problematizar o impacto dessa abstração na realidade precisamos examinar alguns apontamentos sobre como a composição da atmosfera global tornou-se um ativo 
financeiro e um capital fictício, negociado entre atores hegemônicos, ou seja, os Estados, as corporações, as instituições financeiras e os órgãos supranacionais.

Lefebvre (2008a) assinalava, já nos anos 1970, que assim como o espaço, outros elementos naturais, outrora abundantes, estavam se tornando "raros". Por essa razão, teriam como destino adentrar na lógica do circuito de trocas, como as demais mercadorias, passando a ser produzidos, repartidos e distribuídos. Dessa forma sendo introduzidos no rol da economia política. O que esse autor, na época, chamou de "nova raridade" dos elementos naturais essenciais. É fundamental ressaltar que esse processo de "rarefação" é um produto direto da lógica social capitalista que, na incessante busca pela reprodução ampliada de capital, transformou os elementos naturais em forças produtivas ("recursos naturais") consumidas de forma irracional para viabilizar o lucro.

É importante ressaltar que, enquanto os elementos naturais não são escassos à sociedade - estão disponíveis em fartura - eles não dependem das determinações da economia política. Isto é, há algum tempo atrás, não cabia ao Estado ou aos economistas pensar sobre formas de produção e repartição do ar ou da água, justamente por conta da profusão desses. Lefebvre afirma: "Se houvesse abundância de bens não haveria economia política" e, então, complementa que a economia política atua sobre a ideia de "repartição da penúria” (Ibid., p. 121). Ora, na medida em que a água potável e o ar puro (ou qualquer outro componente natural) vão se tornando escassos para o usufruto da sociedade, observa-se que a distribuição desses elementos passa a ser regida segundo as concepções de gestão da economia política. Ou seja, a escassez desses bens tem como consequência o seu ingresso na lógica econômica, nas "leis" do valor. Uma vez raro e útil esses elementos se tornam passível de ser comercializados. Sempre lembrando que as raridades são, elas mesmas, produzidas enquanto tais.

Para Lefebvre, se configuram novas necessidades (sociais e históricas associadas à urbanização) que se tornam, na verdade, uma mediação para a produção, repartição e distribuição de riqueza (Idem). O fato é que a "crise ambiental" se transformou em uma "oportunidade" de obtenção de lucro. Segundo Smith (2006, p. 17, tradução nossa): "a relação da sociedade capitalista com a natureza tornada mercadoria mudou de patamar nas ultimas décadas. Não é mais apenas fonte de valores de uso para matérias primas de produtos."

Em um cenário de capitais ávidos diante da relativa escassez de investimentos rentáveis a economia verde surge como uma oportunidade de uma série de novos 
negócios possíveis ${ }^{159}$. Nota-se um papel preponderante na indústria da despoluição e nos títulos financeiros associados a ela. Esses se baseiam no aproveitamento das externalidades e desperdícios dos processos produtivos já existentes, que antes não tinham valor e que passam a ser reinseridos de maneira lucrativa a situações rentáveis para o capital. Trata-se de uma maneira de internalizar externalidades e "contabilizar o consumo da natureza” (SEABRA, 2013). Segundo CORNETTA (2013, p. 98):

\begin{abstract}
A racionalidade econômica que conduziu durante dois séculos um sistema produtivo marcado por excessos e desperdícios, reconverte-se, hoje, em uma "economia ecológica" que incorpora no processo produtivo parte de suas externalidades ambientais.
\end{abstract}

Faz parte da lógica do capital lidar com suas contradições concebendo supostos remédios para elas em forma de mercadorias. Essas, por sua vez, não fazem mais que deslocar o problema que visavam resolver. Dentre as possibilidades de empreendimentos que a "raridade dos elementos naturais" propõe estão colocados os negócios associados à quantidade de GEE na atmosfera global. A atuação de estadistas e economistas foi (e é) essencial para esse mercado surgir. Isso porque para que esse bem intangível que não tinha nenhum valor comercial passe a tê-lo é necessário que se conforme um arranjo jurídico e institucional que regule sua comercialização. Isto é, há que se criar leis e tratados internacionais que regulem esse novo mercado para ele existir. Exemplos desses arranjos institucionais são o Protocolo de Kyoto e o Plano Nacional sobre Mudanças no Clima, que visam estabelecer parâmetros que permitam e induzam a mercantilização do ar, essa mercadoria invisível.

Por sua vez, regulações nacionais e supranacionais, como essas, estão baseadas em conhecimentos científicos - chancelados pelo IPCC $^{160}$ - que construíram um consenso social hegemônico de que o aumento do efeito estufa de origem antropogênica $^{161}$ é o principal problema ambiental a ser combatido para evitar uma catástrofe ambiental. A partir da conclusão dos cientistas, criou-se uma lógica de

\footnotetext{
${ }^{159}$ Esses novos segmentos de negócios ambientais compõem um lista enorme e crescente, relatamos aqui alguns exemplos: linhas de crédito e fundos de investimentos especializados, créditos ecológicos, serviços de consultoria em negócios ambientais, pesquisa e produção de tecnologias mitigadoras, estoques florestais, publicidade sustentável, entre muitas outras.

${ }^{160}$ O Painel Intergovernamental sobre Mudanças Climáticas (IPCC) é um órgão internacional científico sobre as mudanças climáticas, criado em 1988, pelo Centro Meteorológico Mundial Organização Mundial da Agricultura (WMO) e Programa das Nações Unidas para o Meio Ambiente (PNUMA) para fornecer avaliações regulares sobre a mudança do clima, seus impactos e riscos futuros, além de propor soluções para sua mitigação. Essas avaliações são a base científica para os governos desenvolverem políticas, além de serem base das negociações das conferências da ONU sobre clima, como, por exemplo, em Quioto, em 1997 ou em Paris, em 2015. Informações retiradas de <http://www.ipcc.ch/news_and_events/docs/factsheets/FS_what_ipcc.pdf $>$. Acessado em: 20 de março de 2018.

161 Sobre o processo de estabelecimento desse consenso ver Cornetta, 2008.
} 
mitigação da emissão de GEE, através da mercantilização desses gases, que podem ser transformados em créditos negociados entre empresas e Estados para compensar ações poluentes.

Evidencia-se, portanto, a prevalência da valorização do valor sobre o objetivo real de resolução da problemática ambiental. "Em vez de alterar o nosso sistema econômico de modo a ajustá-lo aos limites naturais do planeta, estamos a redefinir a natureza para adaptá-la ao nosso sistema econômico" (MORENO et al., 2016). É tendo como ponto de partida as "leis" do mercado que a problemática ambiental está sendo encarada $^{162}$. Dito de outra maneira, segundo a lógica capitalista, a natureza precisa ser vendida para ser salva ${ }^{163}$.

É o Protocolo de Quioto - em concordância com o processo de criação de novos mercados - que consagra o surgimento da mercadoria "crédito de carbono". Dessa nova mercadoria se desdobram uma série de atividades, até então, não usuais, como é o caso da produção de energia elétrica a partir de um aterro sanitário.

É condição necessária para a comercialização de uma mercadoria que suas características específicas possam ser abstraídas através da quantificação. No caso do mercado de GEE - cujo elemento básico é a produção e comercialização de moléculas específicas da atmosfera - a mensuração se dá através de toneladas de carbono, medida que pode ser traduzida em um preço. Ou seja, as qualidades específicas do ar de todo o planeta passam a ser reduzidas a toneladas de carbono, para poderem assim ser veículos de valores de troca. Outros GEE também passam a ser medidos através de uma proporção geral relacionada ao carbono, chamada de "gás carbônico equivalente"

\footnotetext{
${ }^{162}$ Sobre esse aspecto faz-se necessário ressaltar que a política econômica mitigadora de gases estufa se estabelece dentro do princípio do "custo benefício". Isto é, as empresas investem em "tecnologias verdes" ou na compra de RCE na medida em que isso possa ampliar seus lucros ou, no máximo, enquanto não os comprometa. Tal fato ficou evidente, a partir de 2008, com acirramento da crise econômica global que desencadeou um marasmo no mercado de créditos de carbono (que persiste até os dias de hoje), revelando que o compromisso primeiro das empresas é com seus próprios ganhos e não com a chamada "sustentabilidade ambiental".

${ }^{163}$ Essa não é uma ideia nova, como demonstra Tomás (1996). Já no século XIX se concebia estabelecer um "equilíbrio ambiental", pela via do mercado através de práticas de compensações financeiras. "Em 1883, o teórico de economia política Marshall já mencionava a necessidade de cobrança de um certo "imposto do ar puro". De acordo com este, os usuários do ar puro haveriam de pagar àqueles que não contavam com a preciosa e "aérea" mercadoria.(...) Nessa circunstância, a solução é: quem pode ter o privilégio de respirar ar puro, que pague por isso. É a única solução que, no final das contas, a sociedade encontra para a questão - embora o termo "solução" crie um relativo e compreensível mal-estar. " (Ibid., p. 8-9). Vale enfatizar a observação da autora de que as "soluções" ambientais mercadológicas, desde essa época, não são eficazes.
} 
$\left(\mathrm{CO}^{2} \mathrm{e}\right)^{164}$. Dessa forma, se institui uma abstração capaz de tornar o ar um valor negociável. Esse esforço intelectual de mensuração soma-se ao esforço político, de arranjo institucional, e permite que moléculas da atmosfera sejam "colocadas na prateleira de mercadorias".

O foco quase exclusivo da política ambiental global na "métrica do carbono" reflete uma obsessão mais profunda relativa à mensuração e à contabilização. O mundo rege-se por abstrações (calorias, quilômetros, quilogramas, e agora toneladas de $\mathrm{CO}^{2} \mathrm{e}$ ) que são aparentemente objetivas e confiáveis, especialmente quando incorporadas na linguagem "especializada" (frequentemente no domínio da economia). Consequentemente, tendemos a ignorar os efeitos da história de cada abstração e as dinâmicas de poder e política que continuam a moldá-la. (MORENO et al., 2016)

A possibilidade da quantificação e precificação do ar é o que oportuniza novas fontes de acumulação de capital ${ }^{165}$. Portanto, a atmosfera que, até recentemente, foi tratada como um bem comum da humanidade, torna-se um meio para a obtenção de ganhos privados.

Tomando como exemplo o caso do Aterro Bandeirantes, observamos que empresas como o banco Itaú, a Biogás e a própria PMSP elevaram seus ganhos financeiros através da apropriação da atmosfera. Nota-se, portanto, um assenhoramento desse recurso coletivo pelas empresas, fato possibilitado graças à quantificação e precificação do ar e, do novo valor de uso que lhe foi conferido. Dessa forma, a busca de resolução dos problemas ambientais, erigida pela via da lógica de mercado, estabelece uma prática de privatização e capitalização da atmosfera terrestre, exemplificando bem o que seria o neoliberalismo ambiental.

$\mathrm{Na}$ atual fase do capitalismo, os "bens livres" da natureza (nesse caso, o ar, mas também as florestas, a água, a biodiversidade etc.), tornam-se propriedades e entram na esfera de valorização de capital ${ }^{166}$. Sob uma aparência de gerar o bem comum (ação de controle das mudanças climáticas, por exemplo), esse tipo de ação se transfigura em um

\footnotetext{
${ }^{164}$ Segundo essa métrica, uma tonelada de gás metano, por exemplo, equivale a 21 toneladas de gás carbônico.

${ }^{165}$ Há que se ressaltar que, toda mercadoria tem como elementos formais o valor de uso e o valor de troca. Nesse caso, o valor de uso é referendado pelos estudos em torno da questão do aquecimento global, sobretudo os chancelados pelo IPCC, que atestam que há uma utilidade social para a não emissão de gases estufa ou mesmo na captura desses. Assim, é importante ter em mente que esse valor de uso só é possível mediante um determinado entendimento sobre a composição atmosférica, que considera os GEE enquanto uma externalidade da produção que ameaça o equilíbrio do clima global e, consequentemente, o equilíbrio dos diversos ecossistemas do planeta.

${ }^{166}$ Smith (2006) estuda esse fenômeno e o denomina "natureza como estratégia de acumulação".
} 
benefício individual para uma empresa, que ao adquirir esse crédito passa a ter o "direito de poluir" ${ }^{167}$.

A atividade produtiva de "regular a quantidade de gases de efeito estufa na atmosfera" pode se dar de diversas formas, separadas em dois tipos principais: aquelas que evitam que gases estufa - que, em condições "normais" seriam lançados à atmosfera - sejam emitidos (como por exemplo, a Termoelétrica Bandeirante); e aquelas que capturam os gases estufa que já estão na atmosfera (como por exemplo, a silvicultura de eucaliptos). É significativo notar que essas ações conjugam atividades produtivas tradicionais (como a produção de energia elétrica ou de madeira) com um novo produto, “o ar com menos GEE”, o que se desdobra em um papel financeiro. Isso quer dizer que essa nova mercadoria - que nada mais é do que a emissão ou a captura de um tipo específico de composição das moléculas de ar - se transforma em bem financeiro e em capital fictício.

Em um contexto no qual a chamada "acumulação financeira" avança (CHESNAIS, 1998) também o ar se torna uma mercadoria e, simultaneamente, se transfigura em um serviço ambiental que pode ser vendido no mercado de futuros, de modo a ingressar no domínio especulativo do mercado financeiro. A abstração contida na precificação da atmosfera ganha contornos ainda mais confusos para o entendimento, ao passo que, em sua gênese, determina-se que essa mercadoria será negociada como um crédito, com atributos similares a qualquer outro tipo de crédito conhecido. Ou seja, a "mercadoria ar" já nasce adaptada ao período de financeirização da economia, comercializada como um papel nos mercados financeiros internacionais. Assim, o crédito de carbono passou a compor o leque de ativos especulativos, adequado à fluidez dos capitais que apostam no aumento dos preços desses papeis e os negociam antes mesmo de sua produção, caracterizando-o como um capital fictício.

Os elementos naturais raros tornados mercadorias reforçam a tendência de acumulação financeira, pois sua rentabilização decorre principalmente da extração rendas (tributos) pela propriedade do bem - seja o ar, seja o terreno, seja a água etc. - e

\footnotetext{
${ }^{167} \mathrm{~A}$ economia verde acaba gerando contradições próprias relativas à possibilidade de ganhos e o direito de poluir, como nesse exemplo: "Quando a União Europeia (UE) lançou seu esquema de comércio de emissões para combater as mudanças climáticas, o bloco provavelmente não considerou a hipótese de que poderia eventualmente fornecer um incentivo para poluir. Um excesso de permissões (créditos de carbono) foi feito e os baixos preços derrotaram o propósito original do esquema. O resultado disso foi o crescimento das importações de carvão para a Europa, com a Inglaterra chegando a importar volumes recordes em 2007. O preço era muito mais barato para as usinas queimarem carvão e comprarem as permissões para poluição, do que comprarem combustíveis mais limpos como o gás natural” (EL KHALILI, 2017).
} 
não da exploração do trabalho produtivo propriamente dito. Em resumo: criam-se novas propriedades, novos ativos, a partir dos quais pode-se extrair renda.

Para tanto, a produção intelectual de discursos - em especial, pelo IPCC e pela mídia, - é muito mais decisiva para que o ar tenha valor, do que a "produção" material do ar em si. Trata-se, sobretudo de uma produção cultural que cria necessidades e confere preço a bens que antes não o tinham. No caso da atmosfera, particularmente, porque se trata de um bem intangível, cujo valor de uso não é visível. É quase um ato de fé atribuir preço às moléculas de ar que mitigarão o efeito estufa antropogênico.

Dessa maneira, nota-se que os ganhos com MDL têm como importante componente a extração de renda fundiária, visto que a remuneração do capital investido origina-se de uma "dádiva" específica do terreno. No caso dos REDD"168 isso é mais evidente, pois o "trabalho" de sequestro de carbono é feito pela floresta, realizando fotossíntese, quase não existindo trabalho humano associado ${ }^{169}$.

No caso dos créditos de carbono do Aterro Bandeirantes é notável o papel da renda territorial, visto que a produção de energia elétrica foi apenas um meio - e não um fim - para que se pudesse capitalizar a renda oriunda da especificidade do terreno, que contém GEE em seu solo. Antes de mais nada, usina foi construída em função da apropriação dos créditos de carbono que seu chão tinha a oferecer, a geração de energia elétrica foi o artifício para tal e a ideia de "salvar o meio ambiente" a representação necessária para a realização do negócio.

Grande parte dos projetos de MDL necessitam de um grande investimento inicial para aquisição das tecnologias necessárias à diminuição de emissões de GEE. Desse modo, para a produção de créditos de carbono há uma fase de captação de recursos no mercado financeiro para o investimento em capital constante. No caso do Aterro Bandeirante, o Unibanco conseguiu reunir cerca de 50 milhões de dólares através de parceria com o Banco do Japão para Cooperação Internacional, possibilitando, assim, o

\footnotetext{
168 "Redução de emissões decorrentes do desmatamento e da degradação de florestas" é um incentivo desenvolvido no âmbito da Convenção - Quadro das Nações Unidas sobre Mudança do Clima (UNFCCC) para recompensar financeiramente ações em países em desenvolvimento por seus resultados de redução de emissões de GEE provenientes do desmatamento e da degradação florestal, considerando o papel da conservação de estoques de carbono florestal, manejo sustentável de florestas e aumento de estoques de carbono florestal. Retirado de <http://redd.mma.gov.br/pt/pub-apresentacoes/item/82-o-que-e-redd > em 13 de outubro de 2017. A negociação de REDD no mercado internacional exige que não haja uso para a madeira existente nos espaços onde se realiza a captura de carbono via fotossíntese.

169 Do ponto de vista da produção da natureza existe, sim, "trabalho morto" nas florestas. Por exemplo, na Amazônia: segundo Furlan (2016) essa é uma "floresta cultural", visto que o histórico manejo dos seres humanos foi decisivo para a existência da cobertura vegetal tal como se apresenta atualmente. Ou seja, também foi produzida. Contudo, o trabalho pretérito materializado nesse espaço manifesta-se nos ganhos da economia verde como renda fundiária capitalizada e não como valor produzido.
} 
início da construção da planta industrial. Trata-se, nesse evento, da possibilidade de um capital excedente materializar-se em capital produtivo que, por sua vez, gera uma mercadoria financeira negociada com os capitais especulativos ${ }^{170}$. Essa transação, inclusive, pode ocorrer antes mesmo de a mercadoria ter sido produzida, através do comércio no mercado de futuros e da promessa de não emissão de GEE.

Podemos desdobrar daí que a atmosfera quantificada em toneladas de carbono pode ser associada a um preço que, no entanto, não tem sua substância dada pela produção real (ou seja, pelo trabalho de diminuição da emissão de GEE), mas, sim pelas variações do mercado financeiro internacional, que vão condicionar, ou não, a demanda por esse ativo.

A capitalização da natureza regula explicitamente tais decisões sociais (as políticas ambientais) de acordo com mercados financeiros. Quando o preço dos créditos ecológicos muda, o investimento prioritário também muda; (...) quando os juros e as taxas de câmbio mudam, as políticas ambientais são diretamente afetadas pelo capital entrando ou saindo. (SMITH, 2006, p. 25, tradução nossa)

Smith se refere aos créditos ecológicos, mas essa citação pode ser desdobrada para os créditos de carbono. Esse fato nos ajuda a compreender o porquê da variação de preço de venda das RCE da PMSP em 2007, 2008 e 2012, que esteve menos atrelada à massa de GEE não emitida e mais determinada pela oscilação do mercado de capitais.

Conclui-se, portanto, que a financeirização e ficcionalização do capital representada pela economia verde, corroboram com a ideia de que esse segmento faz parte do processo de reestruturação produtiva.

Para além disso, os mecanismos financeiros de mitigação do efeito estufa antrópico têm consequência direta na reorganização produtiva do capital fixo, sobretudo no que diz respeito ao emprego de novas forças produtivas que substituam a matriz energética fossilista. A possibilidade de comercialização de MDL como um crédito funciona como incentivo à renovação tecnológica, atrelada a uma menor dependência dos combustíveis fósseis. Se trata de um incentivo, pois os créditos de carbono, por exemplo, ajudam a pagar mais rapidamente o novo capital fixo, diminuindo assim o tempo de rotação do capital investido para a adaptação de matriz energética ${ }^{171}$.

\footnotetext{
${ }^{170}$ Relacionando ao espaço, Smith (1988) fala sobre o movimento de "vaivém" do capital como forma de contrabalancear a taxa decrescente de lucro. Identificar áreas passíveis de capitalização para as empresas transnacionais transformou-se em uma tarefa geopolítica das economias do centro do sistema. Nesse sentido, Perus tornou-se um nó de articulação entre o espaço da cidade e os fluxos de capitais transnacionais, através do Aterro Sanitário.

${ }^{171}$ No caso das usinas de cana de açúcar que adotam MDL ao utilizar o rejeito de cana como fonte de sua energia, observa-se o fato de que há um aumento de composição orgânica do capital no setor, induzido pelos mecanismos de mitigação do efeito estufa antropogênico. Esse processo de renovação tecnológica
} 


\subsection{O "desenvolvimento sustentável" nos bastidores do Banco Mundial}

Para concluir nossas notas sobre a sustentabilidade julgamos importante mencionar um texto de circulação interna do economista chefe do Banco Mundial, Laurence Summers ${ }^{172}$, que vazou para a imprensa em $1991^{173}$, em que ele expõe, sem muitas mediações ideológicas, algumas das características reais e assombrosas do ambientalismo dominante.

O texto trata da localização das "indústrias poluidoras" e nele está contido o desejo de Summers de que o Banco Mundial incentivasse que essas indústrias se alojassem nos países não desenvolvidos, por uma razão econômica: nesses lugares a vida "vale menos", visto que há menos investimentos em pessoas (isto é, em força de trabalho). $\mathrm{O}$ economista considera um desperdício que algumas dessas indústrias não possam ser exportadas (como as geradoras de energia, com alto custo para o transporte de mercadorias), pois sua poluição prejudica os rendimentos nos países centrais, já que são perdidos e/ou desperdiçados investimentos com a mortalidade nesses locais, "onde as vidas valem mais".

O discurso desse chefe de uma instituição hiperpolítica revela como as abstrações regem a sociedade: "para o pensamento burguês, apenas o quantitativo é o sério, o mensurável, o efetivo; e o qualitativo não é mais do que a incerta decoração subjetiva ou artística do verdadeiro real estimado em seu verdadeiro peso" (DEBORD, 2015). A partir de uma visão reificada esse economista justifica contabilmente o imperialismo e porque algumas pessoas devem morrer mais cedo do que outras.

Observada a divisão internacional do trabalho atualmente, pode-se notamos no desejo de Summers uma quase "profecia", pois a maior parte das "indústrias sujas" não tem mais suas plantas instaladas nos países centrais. A exportação da poluição revela o imperialismo contido no neoliberalismo ambiental. O surreal (porém real) raciocínio prossegue afirmando que locais da África estão "subpoluídos", e que deveriam receber mais "indústrias sujas", pois a expectativa de vida é menor e que, por isso, menos pessoas vão viver até o ponto de serem afetadas por problemas de saúde relativos à poluição.

levou diversas usinas a reduzirem seus custos com energia, sendo que algumas tornaram-se autosuficientes.

172 Posteriormente esse economista se tornaria secretário do tesouro do governo estadunidense, e presidente da Universidade de Harvard, dentre outros cargos importantes.

173 O caso ficou conhecido como "memorando Summers" e o texto pode ser acessado na internet, por exemplo no endereço: < http://www. whirledbank.org/ourwords/summers.html >, acesso em: 21 de julho de 2018. 
Esse ideólogo do desenvolvimento sustentável continua sua argumentação pela exportação das "indústrias poluidoras" afirmando que a comercialização de um ambiente limpo, livre de uma "poluição estética" seria um promissor mercado. Por fim, relativiza seus próprios desejos, uma vez que suas recomendações intervencionistas poderiam prejudicar a diretriz do Banco Mundial no sentido de liberalizar a economia.

O objetivo de expor essa anedota histórica é exemplificar, através de um fato real, alguns aspectos teóricos descritos sobre a constituição do "desenvolvimento sustentável", demonstrando que: (i) se trata de uma ideologia de classe; (ii) é veiculada por instituições imperialistas (hiperpolíticas); (iii) as decisões político-econômicasambientais são tomadas a partir de abstrações quantitativas; (iv) um objetivo central do ambientalismo é aumentar as margens de lucro, através da "racionalização" da produção; (v) outro objetivo é a expansão de novos mercados, como no caso dos lugares "livres de poluição estética", enfatizando o caráter contemplativo da "natureza"; (vi) esse ambientalismo guarda características malthusianas, ao versar sobre o controle da vida e morte da população como meio de rentabilizar a produção; (vii) parece uma distopia crer que valores éticos sustentáveis podem regular o capital. 


\section{ANÁLISE DOS PROJETOS DE URBANISMO "SUSTENTÁVEL" DE PERUS}

\subsection{A transformação dos créditos de carbono em urbanismo "sustentável"}

No capítulo anterior pudemos observar a metamorfose de um bem comum com suas características qualitativas - em uma abstração quantitativa, um valor de troca cambiável no mercado. No entanto, essa abstração não se mantém apenas no campo da intangibilidade, ela se torna real, concreta. Isso é notável através da produção de energia elétrica a partir da decomposição do lixo - que não seria economicamente viável, não fosse a existência dos créditos de carbono. Também é perceptível e palpável, posto que o dinheiro arrecadado com os créditos de carbono pela PMSP foi integralmente revertido em projetos urbanísticos sustentáveis na região próxima ao Aterro Bandeirante, observando-se, assim, uma inserção estratégica dos valores gerados pela comercialização da atmosfera, especificamente na textura espacial do bairro de Perus. Buscaremos analisar aqui outra vertente do "desenvolvimento sustentável", os projetos urbanísticos pautados pela ideia de "sustentabilidade".

Nesse movimento, que congrega instituições supranacionais, corporações, tecnocratas e o Estado, estabeleceu-se um ponto de contato entre dois flancos do chamado desenvolvimento sustentável: um mecanismo de desenvolvimento limpo se convertendo em projetos urbanísticos "sustentáveis". Ou seja, dois ramos distintos, da política ambiental contemporânea, complementam-se e conectam-se em uma região periférica da metrópole.

PMSP utilizou as dezenas de milhões arrecadados nos leilões na bolsa em uma série de investimentos na região noroeste, especialmente na subprefeitura de Perus. Por uma questionável determinação da própria PMSP, os recursos dos créditos de carbono devem ser utilizados exclusivamente para recuperação ambiental e desenvolvimento sustentável, não podendo ser destinados para gastos com saúde, educação, moradia etc. $^{174}$

Eis algumas das ações "sustentáveis" realizadas em Perus (e proximidades) com o dinheiro dos créditos de carbono ${ }^{175}$ : projeto, criação e reformas de praças na zona

\footnotetext{
174 Está determinado que todo dinheiro arrecadado com a venda dos créditos de carbono deve ser encaminhado e gerido pelo Fema (Fundo Especial do Meio Ambiente e Desenvolvimento Sustentável), gerido pelo Conselho Gestor do Fema, o Confema (Conselho do Fundo Especial do Meio Ambiente e Desenvolvimento Sustentável), vinculado à Secretária do Verde e Meio Ambiente (SVMA).

${ }^{175}$ As informações sobre como foi gasto o dinheiro dos créditos de carbono da PMSP foram retiradas de Confema, 2012. Todos objetos dos recursos e valores pagos com dinheiros dos créditos de carbono na zona noroeste podem ser consultados no Anexo 1.
} 
noroeste, especialmente em Perus; criação de ecopontos (centros de coleta de resíduos recicláveis); construção do Centro Esportivo de Perus; investimento em material, capacitação e pessoal para o Projeto Zeladores de Praças ${ }^{176}$; criação do Parque Senhor do Vale (Jaraguá); investimentos no Centro de Reabilitação de Animais Silvestres (CRAS) no Parque Anhanguera ${ }^{177}$; criação de uma escola de marcenaria no Parque Anhanguera; desapropriações de terrenos incorporados ao Parque Anhanguera; desapropriação de casas em áreas de risco; projeto do Parque Linear Ribeirão Perus; desapropriações para a realização do Parque Linear Ribeirão Perus; elaboração do Plano de Bairro do Distrito de Perus; o projeto de "urbanização" da Favela Bamburral; entre outras ações.

É central em nossa análise o fato de que a principal destinação dos créditos de carbono da PMSP foi para a compra de terras em Perus. Mais da metade do dinheiro arrecadado nos três leilões foi gasto para ampliar o Parque Anhanguera (cerca de $\mathrm{R} \$$ 20,4 milhões) e para iniciar o Parque Linear Ribeirão Perus (aproximadamente R \$ 19,2 milhões) ${ }^{178}$.

Restam muitas dúvidas sobre o porquê desse investimento público fundiário milionário. Sabendo que se trata de uma área em fase de reestruturação imobiliária, com especificidades como as descritas no capítulo um, levantamos algumas hipóteses: (i) trata-se de um meio de controle do uso do espaço, evitando ocupações de baixa renda, indesejáveis nessa potencial "nova centralidade"; (ii) a expansão das áreas de parque traz maior apelo para a produção e venda de produtos imobiliários próximos a áreas verdes, que seriam uma das marca de Perus pós-reestruturação; (iii) uma maneira de aquecer o mercado imobiliário local, que sem dúvida é impactado por uma compra desse porte, de modo que outras propriedades com essas características passam a ser mais raras no mercado. Sem dúvida essas não são as únicas hipóteses possíveis de serem feitas sobre esse investimento. É curioso notar que o recorte do que é

\footnotetext{
${ }^{176}$ E Projeto que envolve subcontratação de mão de obra para a manutenção das praças. Para mais informações, $\quad$ ver: <http://www.prefeitura.sp.gov.br/cidade/secretarias/trabalho/cursos/operacao_trabalho/index.php?p=1432 05> Acessado em: 17 de maio de 2016.

${ }^{177}$ Uma das reivindicações mais antigas da população de Perus é a instalação de um hospital na região. A saúde humana, na confusa concepção do que é meio ambiente, nesse caso, não pôde ser contemplada ao passo que o CRAS - um moderno hospital para animais silvestres - pôde receber investimentos dessa verba.

${ }^{178}$ A família Natucci foi a principal vendedora de terras para o Parque Anhanguera. Já a família Di Sandro, antiga proprietária de mineradoras em Perus vendeu parte das terras para a realização do Parque Linear (Confema, 2010a; 2010b).
} 
“sustentável” para a PMSP engloba esse tipo de ação imobiliária, mas impede a destinação de recursos para um hospital.

O uso do dinheiro dos créditos de carbono da PMSP para a ampliação dos parques faz parte de uma estratégia de conversão da região de Perus em um lugar "sustentável”, como assinalado no primeiro capítulo. Esse processo, em curso, ocorre tanto no nível simbólico quanto na materialidade espacial. Analisaremos aqui algumas dessas inversões da PMSP que, aparentemente, revelam o que vem se concebendo, nos últimos anos, como um "planejamento urbano ambiental" que congrega esses dois níveis. Objetiva-se tentar identificar algumas diretrizes gerais dessa nova categoria de urbanismo a fim de reconhecer que projeto de cidade está aí contido. Destaque-se que não é só em Perus que essa espécie de planificação vem sendo implantada. A região das represas, na Zona Sul, e as cabeceiras do Rio Aricanduva, na Zona Leste, por exemplo, também são objetos desse urbanismo, que certamente se reproduz em outras cidades ${ }^{179}$. Inclusive, o extremo sul de São Paulo é o local aonde essa categoria do planejamento vem realizando com mais força na materialidade, em nossa opinião, com resultados questionáveis $^{180}$.

Em linhas gerais podemos afirmar que o planejamento pautado pela "sustentabilidade" - em prática na cidade de São Paulo - tem como projeto principal as “infraestruturas verdes", cujo instrumento fundamental é a implantação de parques lineares associadas aos fundos de vales ${ }^{181}$. Outra característica central é a expansão de áreas verdes nas áreas periféricas. Analisando a teoria e a prática desse tipo de planejamento, observamos que essas ações atingem, mormente, as populações mais pobres da cidade, através de remoções com vistas de "recuperação" ambiental. Geralmente não existe contrapartida habitacional adequada acompanhando essa remoção, o que vem agravar a questão da moradia e, contraditoriamente, os próprios problemas ambientais. Outra característica marcante é que o ambientalismo contido nesse urbanismo privilegia o aspecto imagético e visual dos elementos naturais, ou seja, prioriza ações que possibilitem maior contemplação da "natureza" do que aquelas que efetivamente programam uma recuperação ambiental do ecossistema do espaço em questão.

\footnotetext{
${ }^{179}$ Com em Detroit nos E.U.A., por exemplo, processo analisado por Safranky, 2014.

${ }^{180}$ Um exemplo de intervenção urbanística "sustentável” na Zona Sul será citado no item 4.3.

${ }^{181}$ Uma análise mais específica sobre essa política será realizada no capítulo 4.3.
} 
Não podemos negar que há benefícios específicos gerados por alguns desses projetos. No entanto, a hipótese dessa dissertação é que esse tipo de intervenção urbanística tem como característica marcante atuar em sintonia com o mercado imobiliário na capitalização do espaço urbano e reproduzir a segregação socioespacial outros autores chegaram a formulações semelhantes como Bezerra (2017), Migliacci (2016) entre outros.

Parece-nos que a profusão de projetos urbanísticos sustentáveis faz parte de uma estratégia tecnocrática de tentar atrair capitais financeiro-imobiliários para serem investidos em áreas específicas da cidade, onde poderiam impor um novo uso do espaço, como, por exemplo, através da produção de novas mercadorias "verdes": as unidades habitacionais em contato com a "natureza". Os diversos projetos sustentáveis seriam uma espécie de portfólio oferecido ao mercado para atestar que o Estado está em busca de criar as condições necessárias para que esse tipo de produto imobiliário ${ }^{182}$ (e outros) tenha sucesso em Perus.

Os casos de "urbanização" da favela Bamburral, do Parque Linear do Ribeirão Perus e do Plano de Bairro do distrito de Perus são exemplos do urbanismo sustentável (pagos com créditos de carbono) e sua análise nos trará mais elementos para refletirmos a respeito das premissas contidas nos parágrafos anteriores. Antes disso se faz necessário realizar uma introdução destacando algumas das características do urbanismo em geral e, em específico, da sua face correspondente à "cidade sustentável”.

\subsection{A "cidade sustentável" e o urbanis mo enquanto forca produtiva}

Esse subcapítulo se inicia com uma crítica ao urbanismo enquanto prática e ciência que supostamente visa o bem público. Em seguida, desdobraremos essa crítica à "nova" modalidade específica de urbanismo: a "sustentável".

Em seu texto "As instituições da sociedade pós tecnológica”, Lefebvre (2008a) aprofunda a sua crítica às ciências parcelares, enaltecendo a sua ineficácia para lidar com os problemas urbanos contemporâneos. Segundo o autor, o saber disciplinar não é mais capaz de compreender a produção e as contradições do espaço. Dessa maneira, a

\footnotetext{
${ }^{182}$ Rizzi (2011b) realizou uma importante pesquisa sobre a produção dessa "nova mercadoria imobiliária verde" na cidade de São Paulo. Segundo ele, "o mundo natural é apropriado e consumido pela ação imobiliária tão somente enquanto um quadro na parede, ou um artifício camuflado aqui e ali num item ou num serviço. Uma paisagem cênica que chamamos. Por parte do Estado, o mundo natural, materializado nos espaços verdes remanescentes, torna-se uma indulgência oferecido pelas instâncias locais de poder municipal. Por parte do mercado, o mundo natural é uma reminiscência extraída pela semiótica e pela estratégia de marketing e representado pelas tecnologias da informação" (Ibid: 81).
} 
epistemologia e a metodologia das atuais ciências parcelares não mais dão conta de apreender a complexidade do real e, portanto, devem ser repensadas. Para além disso, de forma inconsciente, esses conhecimentos - tal como estão - acabam por produzir “ideologias científicas” que, por sua vez, reproduzem as relações sociais de produção.

Lefebvre, nesse texto, faz um percurso de pensar (e criticar) a economia como a principal ciência que rege a sociedade para, posteriormente, refletir sobre as limitações do urbanismo que aparece como um remediador dos problemas urbanos. Os economistas ao tentarem compreender e ordenar a produção social confundiram a realização do saber com a prática que ele envolve (Ibid.). Quer dizer, os economistas acabaram ligando conhecimento e mercado, sem refletir sobre os problemas que isso pode acarretar. Desse modo, se criou uma associação direta entre a ideia de "bem público" e as ideias de crescimento econômico e de "produtivismo". Essa perigosa "colagem" - ou mais precisamente télescopage $e^{183}$ - de ideias aparece referendada com um "aval científico", configurando uma espécie de ideologia cientificamente criada ${ }^{184}$.

A ciência parcelar econômica ao adotar crescimento econômico e bem público quase como sinônimos, vinculou a elaboração científica a uma ideologia empresarial e fomentou uma visão de que o Estado seria responsável por garantir crescimento econômico e, consequentemente, o bem público.

Evidentemente que desse fato se desdobram inúmeras contradições. Lefebvre identifica, como uma das consequências diretas dessa colagem irrefletida, a configuração de um "caos espacial" (Ibid.), fato visto pelos tecnocratas como uma espécie de externalidade negativa do crescimento econômico geral. Seguindo a lógica fragmentária do conhecimento que predomina em nossa sociedade, não caberia, portanto, à ciência econômica lidar com um problema que é espacial. Embora, sem dúvida, a economia exerça um papel fundante na conformação do espaço. A lógica do conhecimento fracionário impele a outras especialidades acessórias - como ao urbanismo e à geografia - a responsabilidade de tentar resolver esses problemas que aparecem como sendo "exclusivamente espaciais". Enquanto isso a economia continua a ininterrupta busca pelo crescimento econômico.

\footnotetext{
${ }^{183}$ Conceito utilizado por Lefebvre cuja definição elucidativa foi elaboradora pelo tradutor Sérgio Martins em uma nota: “(...) concerne a um encaixe, uma penetração, cuidadosamente ajustado entre dois corpos, a exemplo dos tubos da luneta, de um telescópio, que se encaixam uns nos outros. Ao mesmo tempo, porém, tal interpenetração resulta de uma colisão, de um choque violento, como num abalroamento de trens, após o qual resultaria uma massa compacta e indiscernível” (LEFEBVRE, 2008a, p. 188).

${ }^{184}$ Note-se que essa não é uma característica exclusiva da economia e, sim, das ciências parcelares como um todo.
} 
Passemos, então, a refletir sobre as ciências que se dedicam a pensar o espaço. Essas disciplinas passaram a ter papel mais importante na sociedade ao longo da história recente, pois, além de tratar as diversas facetas do caos espacial, o crescente aumento da importância da produção do espaço na sustentação da reprodução econômica e social, lhes trouxe maior relevância. Diante da tarefa de ordenar o território, os especialistas do urbanismo incorrem no mesmo desacerto de seus colegas da economia: ligar conhecimento científico e mercado, sem refletir ${ }^{185}$. Esse fato nos parece uma forma de ser inerente à produção científica, tal como ela se estruturou historicamente. Vem à tona, sob outro ponto de vista, a confusão entre desenvolvimento econômico e bem público. Nesse caso, no ato de se produzir o conhecimento mistura-se a possibilidade de fazer os capitais se expandirem com a necessidade de se "corrigir" o caos urbano.

A partir dessa prerrogativa, se passa a planejar a produção e o uso do espaço, através de uma série de representações instrumentais que, supostamente, têm o poder de resolver contradições socioespaciais. A elaboração instrumental do conhecimento feita maquinalmente reduz o espaço social a alguns modelos. Esse padrão é elaborado através de uma concepção que mistura cientificidade e ideologia - de maneira deliberada ou não.

Essa mistura de crescimento econômico e bem público caracteriza o urbanismo como uma força produtiva da ciência, cuja finalidade está associada à capitalização do espaço urbano. O planejamento urbano é aqui identificado como parte constitutiva essencial das estratégias político econômicas da produção do espaço como negócio (CARLOS, 2004) e, portanto, subjugado a interesses específicos e não os do coletivo. “Assim, sem o saber, o urbanismo é um urbanismo de classe" (LEFEBVRE, 2008c, p.145)

Damiani (2008) nos mostra como o município de São Paulo está de leste a oeste, de norte a sul coberto e recoberto por distintos projetos de planejamento que se sobrepõem. Alteram-se os nomes (Operação Urbana, Arco do Futuro, Plano de Bairro etc.), porém a essência do urbanismo como instrumental de uma classe se repete:

O "trabalho intelectual" se resolve na realização superestrutural de uma pesada carga legal, de escalas multiplicadas e sobrepostas - leis regionais, municipais e federais; combinadas com regulamentos setoriais - numa enorme burocratização, incluindo além do aparelho estatal, organizações não

\footnotetext{
185 Não é nosso objetivo aqui individualizar a questão acusando pesquisadores de produzirem conhecimento de maneira irrefletida, trata-se de uma busca por descrever um movimento que nos parece geral. Até porque existem os indivíduos que buscam quebrar essa "regra geral" mas, nem por isso, o processo geral é revertido. Porém, em casos diversos nota-se que o tecnocrata do espaço pensa não fazer parte das relações de produção.
} 
governamentais, com vistas a assegurar o enobrecimento dos espaços degradados socialmente, incluindo justificativas sociais, para o que acaba se realizando, especialmente, como uma economia urbana ou produção do espaço urbano. (DAMIANI, 2008, p. 41)

Lefebvre (2008a) afirma que o Estado dispõe o instrumento do planejamento aos "senhores do terreno": os bancos, as empresas do setor imobiliário, os proprietários fundiários - podemos acrescentar, os cotistas dos FII, entre outros. A utilização desse instrumental se faz, especialmente, quando esses se deparam com obstáculos para a expansão da sua reprodução econômica - por exemplo, ocupações de baixa renda em uma rota em processo de especulação imobiliária, ou a necessidade da abertura de novas fronteiras urbanas. Nesse sentido, o urbanismo tem destaque no processo de reestruturação espacial.

De modo geral, em sua prática profissional os tecnocratas concebem o espaço como um cenário, ou seja, um vazio a ser preenchido de maneira funcional, atendendo aos princípios da produtividade (o que inclusive engloba o planejamento de espaços dedicados ao "tempo livre", como um parque), praticamente ignorando a prática espacial contida nesse espaço social. Segundo Lefebvre, o espaço instrumental, concebido nos escritórios, é repetitivo, abstrato e inibe o novo (2008a). O autor complementa que esse espaço cumpre papel essencial para a reprodução das relações sociais de produção capitalistas.

O planejamento, enquanto força produtiva, atua de forma atrelada aos capitais imobiliários. Através dessa coalizão, o espaço adquire as características específicas de uma mercadoria industrialmente produzida. Desse modo, assume a especificidade definidora da forma mercadoria que é a cambialidade, ou seja, a possibilidade de equivalência a qualquer outra mercadoria. Essa característica traz consigo a tendência à homogeinização dos espaços e consequentemente à uniformização das práticas espaciais. A "igualização" dos espaços é central para sua quantificação em preços e para sua adequação a um consumo padronizado, de modo que essa mercadoria possa consumida em larga escala, contemplando os níveis de rentabilidade esperados pelos capitais investidos. E é por isso que uma das razões de ser da produção do "espaço abstrato" se dá pela busca de se criar a sensação de que "passando de um lugar ao outro, tem-se sempre a impressão de voltar para casa” (LEFEBVRE, 2008a, p. 127).

Portanto, o planejamento, ao levar a cabo a instrumentalização do espaço, se configura como uma peça chave para essa possibilidade de quantificação e cambialidade do espaço. A ação de homogeinização que aparece, em um primeiro plano, 
como técnica - que visa o bem público - é, na verdade, uma estratégia de mercantilização.

O espaço estandartizado, consequentemente, também convenciona às práticas espaciais, de maneira que impõe um modo de vida ao determinar os usos aceitos e não aceitos. Nesse sentido é possível afirmar que o planejamento cumpre papel na imposição da "sustentabilidade". O desenho do planejamento estabelece uma totalidade através de imagens espetaculares que reproduzem as relações sociais de produção:

O todo se justifica pelo plano e pelo desenho, por uma pretensa "síntese gráfica" do corpo e do gesto, do espaço e das atividades. Esses grafismos, familiares aos arquitetos e urbanistas (...), intervêm como redutores da realidade que ele pretender re-presentar, e que não passa, aliás, de uma imagem do "modo-de-vida" admitido, e consequentemente, imposto, no habitat (...) (Ibid., grifos do autor)

Quando se trata de justificar a necessidade de realização dos projetos variados, vêm à tona os argumentos técnicos instrumentais, normalmente, ininteligíveis ao senso comum. Por mais participativos que os projetos tentem parecer, a instrumentalização se tornou tamanha que se configurou em uma linguagem não acessível para a imensa maioria da população. A apropriação da linguagem técnica exclusiva aos especialistas leva a população a assistir inerte a (supostos) processos participativos. Desse modo, o planejamento apresenta um argumento (constrangimento) técnico às pessoas, aos lugares, às necessidades. Como no caso observado do Plano de Bairro de Perus, onde a população passivamente legitimava imagens de um novo bairro.

Os argumentos tecnicistas, na verdade, fazem parte do processo de formação da cambialidade do espaço. Logo, muito mais do que argumentos técnicos, esses são argumentos econômicos, desencadeadores da valorização. Contudo, ocorrem sob aparência de assuntos públicos, seja sob roupagem higienista, de moralidade pública, ou ambientalista, "contra o aquecimento global" etc.

O esforço do urbanismo para aparecer como um bem comum esconde seu papel na luta capitalista contra a queda tendencial da taxa de lucro: o de criar condições para a produção e realização da mais valia via capital imobiliário. "O urbanismo encobre essa gigantesca operação. Ele dissimula seus traços fundamentais, seu sentido e finalidade. Ele oculta, sob uma aparência positiva, humanista, tecnológica, a estratégia capitalista: o domínio do espaço, a luta contra a queda tendencial do lucro médio etc." (LEFEBVRE, 2008c, p.141).

Como ressaltado, a ação do Estado é decisiva para criar situações interessantes ao capital imobiliário. Os instrumentos urbanísticos e arquitetônicos são centrais para a 
evolução desse processo, pois redefinem os usos dos espaços, criam centralidades, alteram a ocupação. $\mathrm{O}$ investimento em infraestrutura urbana tende "a se transformar num elemento de enorme importância para a captação de lucros por parte do setor imobiliário-construtor que se apropria dos espaços valorizados pelos investimentos públicos”(KOWARICK, 1980, p. 81).

Nesse sentido, a "cidade sustentável" viabiliza um novo produto para a indústria imobiliária: o habitat em contato com o "verde"186. Como destacado pelo economista chefe do Banco Mundial esse é um mercado com possibilidade de crescimento. Como nas zonas urbanas os "bens naturais livres" são cada vez mais raros, cabe ao urbanismo forjar esse novo nicho de mercado e desenhar novos espaços que se pretendem "naturais". Nesse contexto, as propriedades fundiárias próximas aos raros espaços verdes urbanos se tornam, como resultado, mais valorizadas, o que leva a produção de bens "naturais" a obedecer à lógica imobiliária.

O ideal de "desenvolvimento urbano sustentável" aparece como algo progressista dentro do urbanismo. Além disso, cumpre o papel ideológico de identificarse com o bem público da sociedade, afinal a "cidade sustentável” se apresenta como um desafio de uma geração e não leva em consideração as distintas inserções de classes sociais aí contidas (RODRIGUES, 2005). Esse fato nos leva a identificar uma disputa de discursos em jogo na elaboração de projetos urbanísticos e na sociedade como um todo.

Os movimentos sociais urbanos conseguiram estabelecer um importante parâmetro de luta, ao longo do século XX, no que se refere ao "direito à cidade ${ }^{187}$ ". Com distintas formas, movimentos periféricos buscam como interlocutor o Estado, e se organizam através da pressão popular para conseguir acessar o excedente social sob a forma de melhorias na educação, saúde, transporte, moradia etc. Essa luta histórica logrou a inserção de marcos legais que referendam preceitos do "direito à cidade", estabelecidos, sobretudo, no Estatuto da Cidade (2001). Inversamente, assistimos, sob a bandeira neoliberal, a degradação dessas conquistas através da precarização e empresariamento de diversos serviços urbanos básicos. Junto a esse fenômeno, ganha

\footnotetext{
${ }^{186}$ Lefebvre assinala que o urbanismo cumpre seu papel na sociedade burocrática de consumo dirigido: "Ele dirige o consumo do espaço e do habitat." (2008c, p. 145). Nesse caso o objeto do consumo é o "espaço sustentável”.

187 Ou seja, na luta política institucional por uma reforma urbana "lucidamente utópica" (LEFEBVRE, 2008b, p. 114) com vistas de enfrentar a "estratégia de segregação" (Ibid., p. 113) inerente à urbanização capitalista. Trata-se de um programa que luta pela possibilidade de todos poderem se estabelecer e permanecer na centralidade que é a cidade, independente da situação econômica de cada um.
} 
campo a construção de uma nova retórica que aos poucos vai ofuscando o "direito à cidade" e estabelecendo como paradigma central do planejamento a "cidade sustentável". Nesse sentido ganham espaço as intervenções públicas urbanas voltadas para ações "sustentáveis", ao passo que as ações referentes ao direito à cidade têm perdido a evidência. "O espaço instrumental, assim conceituado, por Henri Lefebvre, na metrópole de São Paulo serve para configurar uma substituição crucial: a neutralização do social por meio da natureza-natural." (DAMIANI, 2008, p.249). O processo é complexo. Não se trata de uma oposição linear, mas faz sentido considerar esses termos dialeticamente, também como uma télescopage. Novamente o campo simbólico se afirma como importante para produção do espaço e renovação imobiliária.

Veremos através dos casos estudados que essa produção vem ocorrendo estrategicamente - sobre áreas ocupadas por camadas mais pobres da população. E que há um esforço por parte dos tecnocratas em justificar que se trata de uma ação que visa o "bem público". Eduardo Jorge, ex-secretário do verde e do meio ambiente de São Paulo, ao justificar um dos projetos urbanísticos sustentáveis de Perus - que envolvia remoções - demonstrou confusão na retórica "sustentável" de "bem público" e relacionou as ocupações de fundo de vale com o aquecimento global, de uma maneira ingênua ou mal intencionada: "Um dos pontos muito importantes no combate ao aquecimento global, lembrem, é você tirar as famílias que estão áreas de risco, que ocuparem várzea de rio, morros, e que ali sofrem ameaça de morrer e colocar em habitação segura ${ }^{188}$ ". Veremos adiante que a "colocar em uma habitação segura" não tem sido um dos principais focos do urbanismo sustentável.

Sem dúvida, as intervenções urbanas públicas sustentáveis interferem na vida da população que já habita a região, seja pela remoção direta ou pelo aumento dos custos de vida. Kowarick alerta que se a sociedade não tem a capacidade de se organizar e se defender “(...) as transformações urbanas só podem se realizar como um rolo compressor que esmaga todos aqueles que não têm recursos para conquistar os benefícios injetados na cidade" (1980, p. 82). Com esses ajustes espaciais a desigualdade social se re-conforma e, no caso do urbanismo sustentável, podemos afirmar que se desdobra em um processo de "gentrificação verde".

A aposta para os novos produtos imobiliários verdes é de que as classes médias e ricas se desloquem para bairros arborizados (distantes do centro) para consumir o

188 Retirado do vídeo institucional da PMSP em https://www.youtube.com/watch?v=ZJ4dLPtDZnk , Acessado em: 5 de março de 2015. 
"verde raro". Fato consonante com a reestruturação imobiliária que se caracteriza pela criação de novas centralidades, a partir da redefinição de usos dos espaços. Essa chegada de novas classes ainda não é uma realidade na zona noroeste, por mais que haja indícios de novos usos ${ }^{189}$ e que haja condomínios suburbanos de alto padrão no Jaraguá, na Serra da Cantareira e nos municípios vizinhos a oeste. Ainda se trata de uma projeção (ou aposta) do capital imobiliário para o futuro.

Os projetos urbanísticos sustentáveis podem exercer influência sobre esse potencial imobiliário. Aqueles financiados pelos créditos de carbono ainda estão parados ou em andamento, isto é, ainda não foram totalmente concluídos. Sua efetivação pode redefinir as projeções do mercado imobiliário, ou não. Analisemos a seguir as características específicas do urbanismo sustentável proposto para Perus, para buscar verificar na prática o que se concebe por “desenvolvimento urbano sustentável”.

\subsection{O Parque Linear do Ribeirão Perus}

O Parque Linear do Ribeirão Perus constava no PRE desde 2004. Em 2008 foi aprovada sua implementação ${ }^{190}$. Inicialmente, sua realização foi concebida como uma contrapartida ambiental para a construção do Rodoanel Oeste. No entanto, isso não ocorreu. A PMSP investiu aproximadamente R \$20,5 milhões do dinheiro oriundo dos créditos de carbono para a contratação de especialistas responsáveis pela elaboração do projeto $^{191}$ e, também para desapropriações iniciais para implantação do Parque. O orçamento inicial previsto para a execução do Parque era de R 190 milhões, além dos valores para desapropriações.

O parque linear é o principal instrumento planejado e aplicado pelo urbanismo sustentável - teoricamente - para a solução de problemas socioambientais. Existem diversos projetados e implantados em São Paulo. No próximo capítulo será realizada uma análise mais geral da utilização desse instrumento como política pública na metrópole como um todo ${ }^{192}$.

O Parque Linear do Ribeirão Perus atravessa ao meio a área urbanizada do

\footnotetext{
${ }^{189}$ Como, por exemplo, os empreendimentos imobiliários em Caieiras, os condomínios em construção no antigo terreno da família Peccicacco, como destacado no primeiro capítulo.

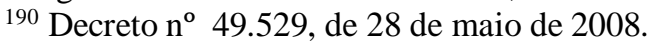

${ }^{191}$ A Prefeitura contratou a FUPAM (Fundação para a Pesquisa em Arquitetura e Ambiente) para elaborar o projeto.

${ }^{192}$ Relembrando que os parques lineares têm como proposta recuperar os ecossistemas ao longo da rede hídrica, buscando estabelecer áreas de vegetação conectadas e, também, visando controlar as enchentes. Além disso, objetiva-se transformar esses espaços em áreas de lazer de uso sustentável Uma definição mais completa de "parque linear" pode ser encontrada no item 4.3.
} 
bairro, acompanhando parte do leito do córrego Areião ${ }^{193}$ e do Ribeirão Perus desde o sul do distrito seguindo em direção noroeste, até chegar à área da fábrica de cimento (não inclusa no projeto). A previsão é que o Parque tenha uma área total de 1.017.289,00 $\mathrm{m}^{2}$. O projeto é assim justificado por atuar no controle de enchentes e na recuperação ecológica. Há também a descrição de que esse espaço será utilizado como área de educação ambiental, de lazer e como um "corredor cultural" (não havendo mais detalhes sobre o que significaria esse último conceito). Destacaremos apenas alguns pontos mais relevantes em nossa análise.

Segundo Sandeville Jr. e Angileli (2013), o projeto "não atende aos quesitos ecológicos de um parque linear e não considera demandas da população local em sua concepção" ${ }^{194}$. Isto é, segundo essa análise técnica, o projeto sustentável não atende as determinações ecológicas! Esse não é um caso isolado - como veremos em outros exemplos - o que poderia justificar que esse é um problema desse projeto em si e não do urbanismo sustentável como um todo.

A não participação da população na elaboração do projeto, apresentado pronto aos moradores, gerou insatisfação e questionamentos da população local. Isso porque para que o empreendimento ocorra, tal qual proposto pela PMSP, será necessário remover forçadamente muitas famílias. A divulgação sobre o número preciso de famílias removidas e quais seriam os procedimentos para esse deslocamento não foram encontrados em nenhum dos documentos pesquisados. Entretanto, sem dúvida, se trata de uma quantidade grande de famílias, como podemos estimar observando o Mapa 7.

De 2008 para cá o que a PMSP realizou do projeto foi a desapropriação de chácaras ao sul do Rodoanel, em uma área praticamente não ocupada ${ }^{195}$. De certa forma, a PMSP "reservou" esse terreno, controlando seu uso. Fora isso nada mais foi feito nesses dez anos. Bezerra (2017) relata que um terreno específico desse trecho do projeto, na margem direita do rio, foi excluído da área do Parque, fato contraditório ao fundamento técnico de recuperação ecológica. Coincidentemente - ou não - esse terreno pertence a uma grande empresa mineradora da região.

As outras fases do projeto envolvem remoções. No trecho Junção, próximo ao

\footnotetext{
193 Importante contribuinte da margem direita do Ribeirão Perus, cujas nascentes estão localizadas na Serra da Cantareira.

${ }^{194}$ Uma análise mais detalhada sobre o projeto em si pode ser encontrada em Bezerra (2017) e Sandeville Jr. e Angileli (2013).

195 O projeto que esteve parado nos últimos anos foi retomado recentemente, através do anúncio - no Diário Oficial do Município de São Paulo do dia 7 de julho de 2016 (SÃO PAULO) - que a PMSP ainda vai investir uma quantia de aproximada de R\$ 185 milhões para a finalização das obras do Parque Linear. Contudo, nessa data foram liberados apenas R \$ 2 milhões pela PMSP.
} 
Rodoanel, serão removidas cerca de 40 famílias, além de algumas empresas. Sandeville Jr. e Angileli (2013) relatam a existência de famílias, que ocupam o local há mais de cem anos, que teriam que ser deslocadas. Relatam uma simbólica fala de um morador de 85 anos, que sempre morou ali: "depois de tudo o que passaram na precariedade que aquilo era, e quando a região melhora, e tem a valorização do Rodoanel, agora tem que tirar?’. A nosso ver, de certa forma, esse senhor expõe o processo de reestruturação produtiva induzido pelo Rodoanel e complementado pelo urbanismo sustentável, que redefine a possibilidade de capitalização do espaço e efetiva essa redefinição através de remoções das pessoas e usos antigos, não condizentes com a possibilidade de rentabilização.

Os trechos Areião, Girassóis e Centro preveem também a instalação do parque em áreas hoje ocupadas. Sendo que esses dois últimos trechos conteriam a maioria das remoções, pois atravessam o bairro em sua área central, gerando insegurança em diversas famílias e inclusive no movimento social Comunidade Cultural Quilombaque que está no caminho do Parque.

Nos estudos realizados para a elaboração do Parque Linear de Perus, não está prevista uma solução habitacional viável para todas as famílias que serão desalojadas de suas casas. Assim, é possível observar uma característica central do urbanismo sustentável: sua realização prevê um número elevado de remoções forçadas, entretanto, não são estabelecidas contrapartidas habitacionais que deem conta, efetivamente, de garantir o direito à moradia adequada para as famílias afetadas. Ou seja, não parece fazer parte dos critérios de sustentabilidade do planejamento urbano a provisão de moradia digna para os atingidos pelos projetos.

Também merece destaque a enorme contradição do projeto que é a exclusão da parte final do Ribeirão Perus do parque. Justamente quando esse rio adentra no terreno da fábrica de cimento, o Parque Linear acaba. Qual justificativa possível para explicar que áreas densamente ocupadas sejam alvo de intervenção e esse local, praticamente desocupado há décadas, seja descartado do projeto? Do ponto de vista da racionalidade ecológica esse trecho seria essencial para conectar a vegetação ciliar até a foz do ribeirão Perus em seu encontro com o Rio Juqueri e com a área vegetada do Parque Anhanguera. O estratégico desvio que o desenho do Parque Linear faz dos terrenos que envolvem importantes interesses econômicos traz maior aderência ao argumento de que esse instrumento urbanístico tem a finalidade de controlar o tipo de uso do espaço. Além disso, enfatizam o caráter do ambientalismo autonomizado, como uma representação de 
si mesmo - que, no limite, existe para atender as exigências de mercado.

\subsection{O "Complexo do Bamburral": análise de uma remocão "sustentável"}

\section{Apresentação do projeto}

A "urbanização do Complexo do Bamburral" é, ao mesmo tempo, uma intervenção urbanística habitacional e "sustentável". O empreendimento iniciado em 2010 é coordenado pela Secretária de Habitação (Sehab). Para ele foram destinados $\mathrm{R} \$ 5.148 .267,60$ dos recursos dos créditos de carbono da SVMA ${ }^{196}$.

O projeto está inserido na bacia do córrego das Laranjeiras - corpo d'água que atravessa o Aterro Sanitário Bandeirantes -, em área imediatamente contínua ao terreno do Aterro, onde há densa ocupação urbana. Segundo a Sehab (São Paulo, 2013), a área de abrangência do complexo compreende as favelas Bamburral, Cidade das Crianças, Jardim Esperança e Árvore de São Tomás (Figura 8). É importante ressaltar que nem todo espaço atingido pelo projeto deve ser classificado como favela, pois parte das casas são oriundas de loteamento irregular do Jardim do Russo. Além disso, havia imóveis antigos, bem consolidados, que diferiam muito do padrão construtivo característico de uma favela. Toda área do complexo é demarcada como ZEIS.

O sítio correspondente é composto por um estreito vale, onde passa o córrego das Laranjeiras, comprimido por encostas íngremes às duas margens. Também abrange a área de um pequeno afluente - tamponado - a oeste, advindo da Rua Árvore de São Tomás. A justificativa técnica utilizada pela PMSP para realizar essa intervenção é o risco de deslizamento, dado pelo alto declive. Estudos realizados pelo IPT (Instituto de Pesquisas Tecnológicas) identificaram áreas com alto ou muito alto risco de deslizamento, que deveriam ser realocadas. Entretanto, a PMSP também demarcou diversas casas em áreas de médio ou baixo risco para serem removidas. A justificativa era conseguir uma área maior que permitisse a realização de um projeto arquitetônico melhor acabado ${ }^{197}$. As enchentes que atingiam as casas mais próximas ao córrego das Laranjeiras também foram utilizadas na argumentação para intervenção.

O Complexo está dividido em três fases (Figura 8). A primeira, chamada de "Bamburral", iniciou as remoções em 2010 e tinha previsão de término das obras para

\footnotetext{
196 O valor total previsto, inicialmente, para o complexo era de R 124 milhões.

197 Devido à proximidade com o Aterro Bandeirantes a PMSP realizou, antes das obras, estudos sobre a qualidade do solo e da água na área do Bamburral e diagnosticou um nível de contaminação, não muito grave, possibilitando a ocupação humana do local.
} 
2014, mas até hoje não foi concluída. O objetivo proposto era "urbanizar" a favela da Bamburral através da construção de um "conjunto habitacional sustentável”, associado a um pequeno parque linear no córrego das Laranjeiras.

O escritório Brasil Arquitetura foi contratado pela PMSP como projetista. Seu projeto prevê a construção de 234 apartamentos em cinco prédios, além de um canal a céu aberto para o córrego das Laranjeiras, com margens livres de quaisquer construções, ocupada por vegetação e algum equipamento de lazer - nos moldes dos projetos de parques lineares que vêm sendo implantados pela PMSP nos últimos tempos ${ }^{198}$. Prevê também a implantação de redes de água, luz e esgoto; pavimentação; iluminação pública e paisagismo. Tudo isso em uma área $31.210 \mathrm{~m}^{2}$. Para essa fase, foram removidas de suas casas 294 famílias ${ }^{199}$. O total de famílias "beneficiadas"200" nas três fases do plano será de 529 (ver mapas 4 e 5).

Segundo a Sehab, as famílias que já foram removidas têm prioridade para a compra dos apartamentos que serão construídos. Caso não seja possível abrigar a todos, algumas famílias serão encaminhadas para outro conjunto habitacional municipal. Ainda, segundo essa secretaria, no ato da remoção, 242 famílias optaram por receber auxílio-aluguel - atualmente no valor de $\mathrm{R} \$ 400,00$ - como contrapartida para esperarem a construção dos apartamentos ${ }^{201}$. Outras 52 famílias optaram por receber R\$13 mil de indenização, renunciando à possibilidade de compra do apartamento ${ }^{202}$. Essas foram as duas opções colocadas pela PMSP aos removidos: auxílio-aluguel mensal ou indenização única ${ }^{203}$. Atualmente, 253 famílias recebem auxílio aluguel na subprefeitura de Perus ${ }^{204}$.

\footnotetext{
${ }^{198}$ Existe a possibilidade futura de extensão desse "mini Parque Linear do Bamburral" até a favela da Beija Flor, à jusante do córrego, que não está incluída no Complexo do Bamburral. Essa é uma previsão contida no Plano de Bairro de Perus (ver mapa 6 e 7).

${ }^{199}$ Esse número oficial não corresponde à realidade, pois nos terrenos em que havia mais de uma família morando - por exemplo, em casas de fundo ou sobrados -, a PMSP contabilizou apenas como uma só família e, consequentemente, pagou uma só indenização. Além disso, não há dados claros sobre quantas famílias serão removidas no total das três fases do projeto. No documento da Brasil Arquitetura (2011) aparece a informação de 374 remoções, mas não necessariamente esse é o número real.

${ }^{200}$ Termo utilizado pela Sehab.

${ }^{201}$ Por contrato esse repasse deve ser feito pela PMSP mensalmente até o dia de entrega do apartamento.

${ }^{202}$ É importante registrar que o valor padrão pago pela PMSP para casos como esse era de R\$8.000. Os motivos de um pagamento maior que o habitual não estão claros. Entretanto, é possível levantar a hipótese de a PMSP estar interessada em acelerar o processo de remoção oferecendo para isso uma indenização maior que a média. Houve casos de moradores que, de forma individual, resistiram juridicamente e acabaram recebendo uma compensação em dinheiro mais alta.

${ }^{203}$ As famílias que optaram pelo auxílio-aluguel podem desistir ao longo do processo de espera e optar pela indenização única. Está implícito que essa é uma aposta da Sehab para conseguir abrigar todas as famílias nesse conjunto habitacional.

204 Número que engloba outros removidos, não só do Bamburral. Retirado de <http://www.habitasampa.inf.br/php/pdfs/auxilioaluguel/auxilioaluguel.pdf > em 13 de setembro de 2018.
} 
Os serviços executados até os dias de hoje (outubro de 2018) foram remoções, canalização do córrego, construção de um muro de arrimo. Dois prédios estão em fase final de construção e, os outros três têm só as fundações feitas. Ao longo desses oito anos as obras ficaram paradas, ou andaram em um ritmo muito lento. Segundo moradores, durante o longo período de obras paradas, algumas famílias ocuparam o terreno, construindo barracos no canteiro abandonado. Houve ação de reintegração de posse do terreno com confronto entre os ocupantes e a polícia. Logo após esse fato, a PMSP retomou as obras dos prédios. Alguns entrevistados interpretam que essa ocupação foi uma forma de pressão popular (talvez até involuntária) decisiva para garantir a continuidade das obras.

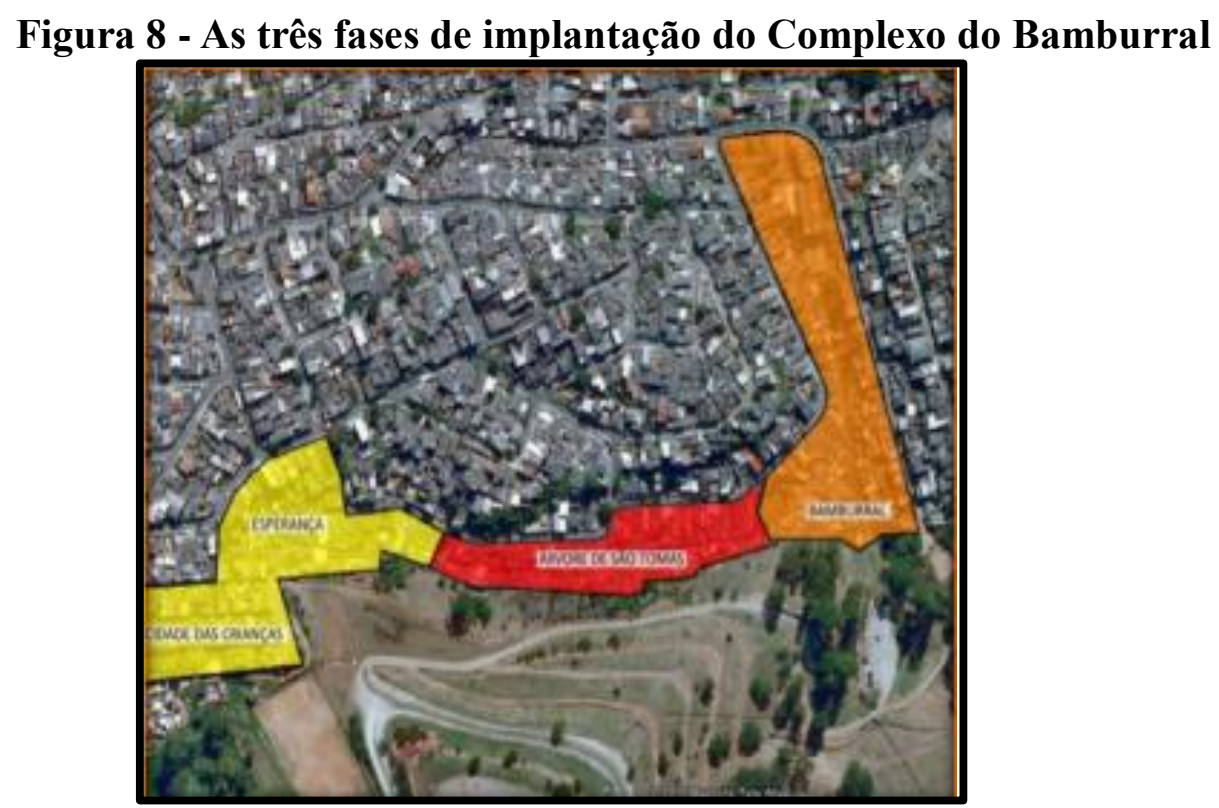

Fonte: São Paulo, 2013.

A segunda fase do "Complexo do Bamburral" - relativa à Rua Árvore de São Tomás ${ }^{205}$ - e a terceira - correspondente às favelas Esperança e Cidade das Crianças ainda estão em fase de projeto, segundo a Sehab, mas circulam informações entre os moradores de casas que possivelmente seriam removidas. Parte da área da segunda fase é pertencente ao terreno do Aterro e deverá ser devolvida à PMSP. Como as famílias removidas dessas fases do Complexo não caberiam no futuro conjunto habitacional do Bamburral, a Sehab afirmou que planeja construir outro conjunto, com 1200 unidades habitacionais, na parte sul do distrito de Perus, próxima ao Rodoanel (um terreno conhecido como Badras). Contudo, se após tantos anos nem os prédios do Bamburral foram concluídos, é difícil crer que esse outro conjunto se realize tão cedo.

\footnotetext{
${ }^{205}$ As casas desse espaço estão assentadas ao redor de um afluente do córrego das Laranjeiras que foi canalizado e tamponado pelos próprios moradores em mutirão, com material fornecido pela subprefeitura.
} 
Mapa 4 - Casas inseridas no projeto Complexo do Bamburral

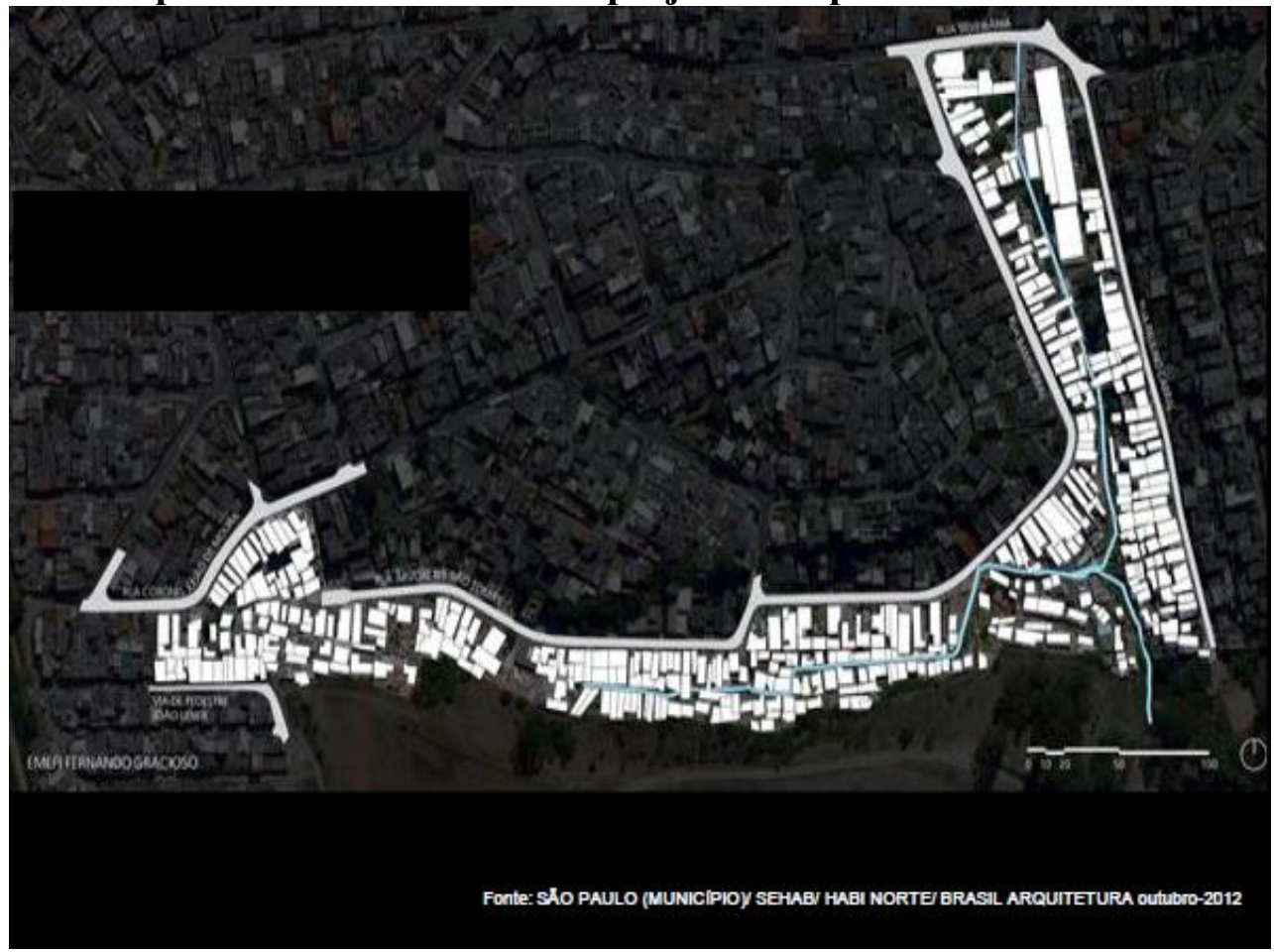

Mapa 5 - Projeto de casas removidas no Complexo do Bamburral

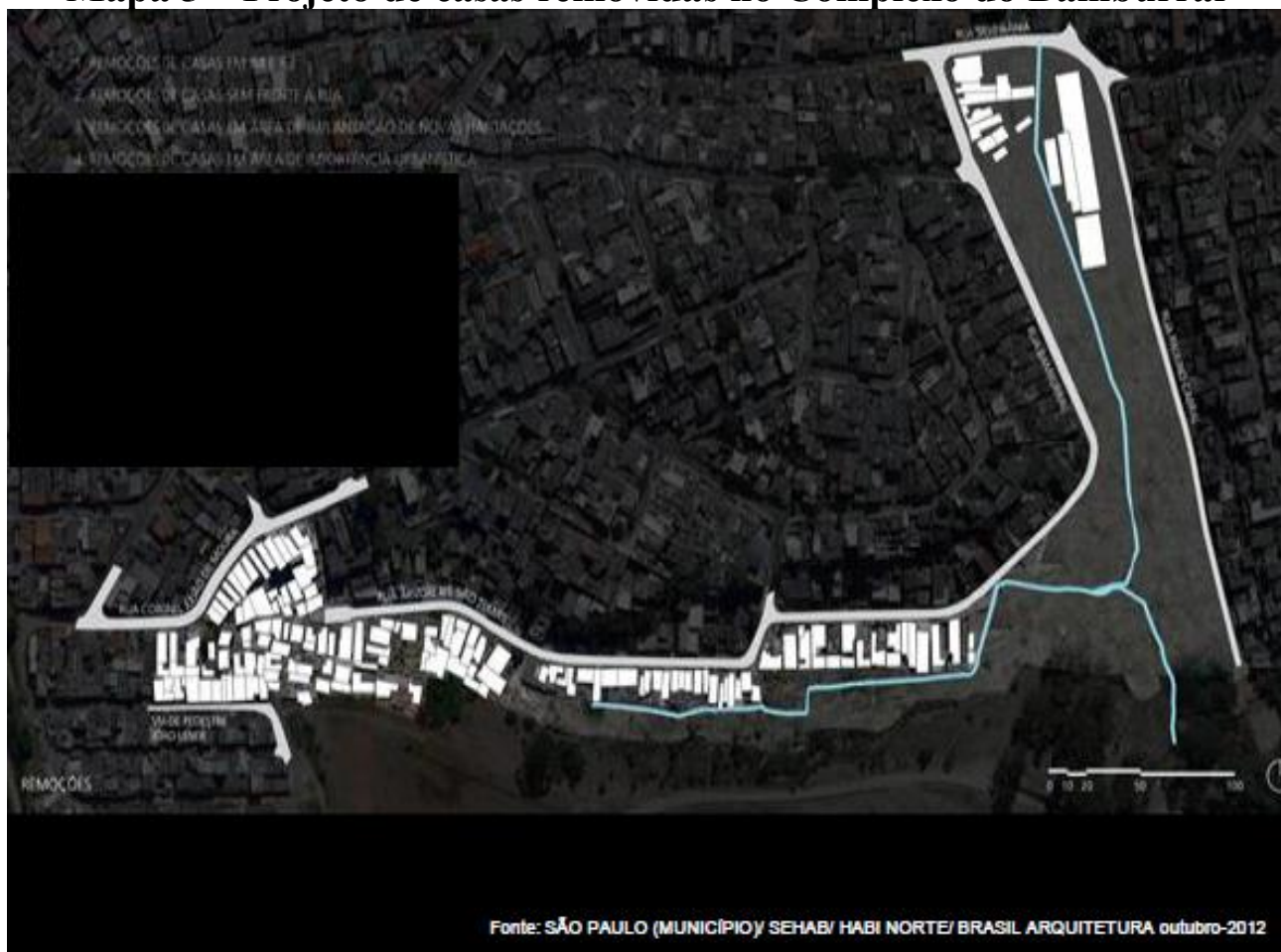

A remoção forçada como forma de expropriação

À sombra das grandes cifras, projetos e obras estão os ex-habitantes removidos que, desde o início são coadjuvantes desse processo. Buscaremos expor - a partir do conteúdo dos depoimentos de alguns atingidos pela remoção - como esse processo revela um momento de expropriação através da espoliação material, pressão psicológica 
e aumento dos custos de vida. É importante afirmar de saída que não se advoga contra a construção de habitação social, pelo contrário. No entanto, em uma reflexão crítica, é necessário enfrentar analiticamente algumas limitações dessa política.

Segundo relatos dos ex-moradores do Bamburral, o projeto de reurbanização foi apresentado à população local já pronto. Houve reuniões individualizadas ou pequenos grupos para "dar aparência de que foi algo participativo", porém nenhuma das reinvindicações dos moradores foi atendida. Alguns reclamaram da falta de transparência do processo por parte da PMSP. É notável que há grande receio por parte dos afetados para falar sobre o tema da remoção, pois muitos têm medo de que o que disserem possa prejudica-los de alguma forma no momento da entrega dos apartamentos. O temor de uma suposta retaliação nos parece sintomático sobre a forma como a PMSP vem conduzindo esse processo.

O inédito projeto de um conjunto habitacional "sustentável", financiado por créditos de carbono causou uma série de impactos negativos - diretos e indiretos - na vida do bairro. Como já destacado no primeiro capítulo, houve aumento dos preços imobiliários de toda a região, por conta das centenas de remoções. Os R $\$ 450$ mensais ou os R\$ 13 mil em parcela única eram insuficientes para alugar ou comprar um imóvel em Perus. Além disso, para as famílias com muitos membros foi ainda mais dificultoso alugar ou comprar um imóvel na mesma região, pois o preço da indenização repassado pela PMSP é fixo, independentemente do número de pessoas que moravam na casa.

Outro agravante para os deslocados - justamente pelo fato de ter havido um encarecimento geral dos imóveis em Perus desde o anúncio da realização do Complexo - é que o tamanho das casas alugadas, geralmente, era bem menor que as casas onde viviam anteriormente. A nova moradia menor, associada ao fato de haver custos para se realizar a mudança, fez com muitas famílias se desfizessem de boa parte de seus bens: algumas deixaram para trás móveis, eletrodomésticos, entre outras coisas de valor material e imaterial. A partir desse fato, podemos inferir que esse tipo de remoção é um meio de expropriação em distintos níveis. Não só da terra e do imóvel, mas também dos vários bens adquiridos pelas famílias. Na prática, a remoção funciona, em muitos casos, como um meio de "queima" do pequeno enriquecimento que o trabalhador urbano pôde conseguir, reiterando assim sua condição proletarizada, ainda mais fragilizada. Esse tipo de inconveniente não é levado em conta pelos tecnocratas ao elaborarem os projetos "sustentáveis".

Em contraposição, pode-se argumentar que os moradores terão acesso a compra 
de um apartamento legalizado, com subsídio estatal. Contudo, essa compra causa várias implicações, inclusive, a necessidade de novo gasto para readquirir bens mobiliários adequados ao novo apartamento. Não é nenhuma novidade afirmar que o acesso à moradia social, na forma de HIS (Habitação de Interesse Social), impõe aumento do custo de vida para boa parte dos removidos. Ao pagamento de prestações mensais, por no mínimo uma década ${ }^{206}$, se somará uma taxa de condomínio, além das contas de água e luz, que parte dos removidos não pagava, pois se utilizavam de ligações irregulares. Além disso, a PMSP vai entregar apenas os pisos do banheiro e cozinha instalados, cabendo aos novos condôminos arcar com os custos dos pisos dos dois quartos e sala. Outro custo a mais que os removidos preveem é para guardar seus automóveis, visto que o projeto não prevê área de estacionamento.

A soma desses pequenos custos pode ser definitiva para que famílias não consigam se manter no local. DAMIANI (2009, p. 336), resume essa limitação da política de habitação social:

\begin{abstract}
A inclusão de territórios de uso da população proletarizada, sob o avanço dos processos de capitalização e valorização do espaço e do ideário da sustentabilidade, como seu adorno, conveniente, expõe essa população a formas de expropriação compulsórias; a indicação de seu reassentamento na área de entorno, na maioria das vezes, não se concretiza e, quando o faz, essa mesma população tem dificuldades na manutenção da nova condição, pelos custos adicionais cotidianos que ela representa, como conta de água e luz, na substituição da condição de favelada pela de moradora de conjuntos habitacionais, por exemplo.
\end{abstract}

Além disso, o endividamento significa comprometimento de "trabalho futuro" e passa a reger o cotidiano. A dívida pela mercadoria habitação se torna uma constante no orçamento mensal e, provavelmente, se soma a outras dívidas, como as contraídas em lojas de varejo de móveis e eletrodomésticos, por exemplo. Desse modo, o acesso à moradia via crédito empenha e rege o emprego do tempo do trabalhador durante anos, obrigando-o a ter uma renda constante. O que não é tarefa simples de ser enfrentada em um contexto de crise do trabalho - que aparece como precarização do trabalho, desemprego, entre outras formas ${ }^{207}$. A inadimplência pode significar a perda da moradia, além de outros constrangimentos morais e psicológicos. A ideia contida nesse parágrafo também se aplica aos trabalhadores que acessam a mercadoria habitação via o programa Minha Casa Minha Vida, ou outro crédito.

\footnotetext{
206 Segundo acordo com a PMSP os moradores do conjunto habitacional não podem vender seu apartamento antes de dez anos de pagamento de prestações. Também não podem alugar as unidades.

207 “Observe-se que não há condições de pagamento de qualquer moradia por uma população crescente de miseráveis, produzidos como tais por uma economia que gera excedentes de trabalhadores potenciais e empobrecimento crescente (...)" (DAMIANI, 2010, p. 39).
} 
Nesse sentido, podemos notar que, mesmo o acesso à moradia via crédito subsidiado, de certa, forma seleciona quem vai conseguir morar nesses apartamentos. A seleção se dá pelo nível de renda que cada família tem para pagar as novas contas que surgirão no seu cotidiano, e que passam a mediar a relação deles com os bens básicos para sua reprodução. Quem não conseguir manter essa estabilidade financeira provavelmente irá para outra ocupação informal, e/ou para uma região mais afastada. $\mathrm{O}$ que reitera o processo de gentrificação.

Essa não é uma contradição nova, KOWARICK (1980, p.60), nos anos setenta já realizava semelhante crítica:

Até mesmo os programas que se destinam para a assim chamada demanda de
'interesse social', não só são quantitativamente pouco expressivos, como
também, freqüentemente, as camadas que deveriam ser beneficiadas não têm
condições de amortizar as prestações previstas pelas fantasiosas soluções
oficiais. O resultado é que as habitações ou ficam vazias ou acabam sendo
transferidas para os grupos de renda mais elevada enquanto que as pessoas a
quem se destinavam os programas subsidiados pelo poder público acabam
voltando às suas condições originais de moradia (...).

Evidentemente que alguns tecnocratas têm consciência das contradições envolvidas nos mecanismos de habitação social. No entanto, há uma naturalização desse processo de expropriação e re-expropriação. Durante a $70^{\mathrm{a}}$ audiência do Confema o Conselheiro Alexandre questionou sobre a ação de remover os moradores: "Entendi. Isso, eu acho que foge do escopo aqui, do Fema e do que a gente está aprovando, mas é um tipo de ação, talvez, de encaminhamento que pode gerar problemas futuros, dessa família ir para outra área de risco também.” Tibiriçá, funcionário da Sehab responde: “(...) Nada garante. Se a gente, um dia, encontrar essa família de novo e ela está em outra favela, a gente vai ter que atender novamente" (Confema, 2012, p. 9). O “atender" dito por Tibiriçá, pode ser lido - de acordo com a prática que vem se repetindo na Sehab nos últimos anos - como uma remoção acompanhada de uma precária indenização. Assim, a questão da moradia - e da população pobre - vai sendo empurrada adiante.

O longo tempo de espera também é um meio de expropriação. Outro custo não contabilizado pelos tecnocratas é o dinheiro extra necessário para inteirar o aluguel (visto que o auxílio da PMSP é insuficiente) ao longo dos anos sem adentrar ao conjunto habitacional, o que se configura como mais uma forma lenta de espoliação, visto que, em geral, as pessoas removidas tem uma inserção precária no mercado de trabalho ${ }^{208}$.

${ }^{208}$ Segundo o diagnóstico do Relatório Analítico da Situação Cadastral da Sehab (SÃO PAULO, 2011), em 2011 a proporção de habitantes removidos da Bamburral com emprego estável era por volta de 57\%. Estatística que se refere à população economicamente ativa. Segundo este relatório, o índice de desemprego era de $15 \%$. Os demais ocupados distribuíam-se em postos de trabalho com alguma 
Em depoimento realizado em 2018, Silmara - que optou pelo auxílio aluguel -, contou sobre sua trajetória nos oito anos desde que foi removida:

Nesse tempo moramos em várias casa, essa que eu to agora é a quarta, depois que eu sai de lá foi quatro casas. (...) Todas aqui em Perus. Pra pagar o aluguel tem que inteirar... o bolsa aluguel não dá tudo, porque você num acha casa de aluguel no valor que eles dão. Já foi até conversado isso com eles (os representantes de Sehab), mas eles falaram que é pra esperar.

Reafirma-se a expropriação como um elemento intensificador da "mobilidade da força de trabalho" (GAUDEMAR, 1977). Em 2013 o garoto Carlos - na época com 13 anos - nos concedeu um depoimento sobre sua história de vida antes e depois da remoção. Ele nasceu em Franco da Rocha, mas veio bebê para o Jardim do Russo. Morava na Rua Árvore de São Tomás e, então, se mudou para a rua do Bamburral. Passou toda a infância por lá e por isso conhece a todos na rua - o que evidencia os laços afetivos que tem com o lugar. Na época, morava em Francisco Morato, mas afirmou que gostaria de poder voltar todos os fins de semana para rever os amigos em Perus. Antes da remoção, morava em uma casa de bloco com complemento de madeira, junto de sua mãe e alguns dos seus nove irmãos. Contou também sobre como eram as brincadeiras com as outras crianças no córrego das Laranjeiras.

Em 2011, sua família foi removida e optou pela indenização única, de R\$ 13 mil. Após dois anos que já haviam se deslocado para quatro locais diferentes: saíram da favela Bamburral para a favela da Beija Flor (à jusante no córrego das Laranjeiras); de lá partiram para a Bahia (BA); depois retornaram, no Recanto dos Humildes e, finalmente, foram para Francisco Morato. A volta da Bahia se deu, porque sua mãe não conseguiu emprego por lá; porém alguns de seus irmãos ficaram pelo nordeste. Antes da remoção sua mãe trabalhava no supermercado Pão de Açúcar e foi demitida por um problema no pulso. Na época, ela vivia de "fazer tudo", doméstica, feirante, entre outros "bicos".

Destacamos novamente a importância de estarmos atentos à mobilidade da força de trabalho como meio de compreender a dinâmica econômico espacial. Não foi possível descobrir onde estão atualmente todas as (mais de) 294 famílias removidas forçadamente de suas casas. $\mathrm{O}$ único dado que conseguimos junto à Sehab foi o primeiro local para onde essas famílias se mudaram após a sua remoção (ver Tabela 5).

precariedade, ou postos menos protegidos. A população considerada inativa era de $28 \%$. É evidente que essa estatística é meramente ilustrativa do fenômeno, mas é sintomático do processo de crise do trabalho que pouco mais da metade das pessoas que conseguiam obter renda, o façam através de um emprego estável. Muito provavelmente esse número, atualmente, seja ainda menor. Além disso, praticamente $25 \%$ da população do Complexo do Bamburral se beneficiava de algum tipo de programa de complemento de renda. 
Mesmo desatualizados esses dados dão algumas indicações de locais preferenciais para a migração. É muito provável que diversas famílias já tenham se mudado do primeiro local após a remoção, pois, como vistos nos dois exemplos anteriores há pouca estabilidade na vida desses expropriados.

Tabela 5 - Local de destino das 294 famílias logo após a remoção do Complexo do Bamburral

\begin{tabular}{|l|c|}
\hline \multicolumn{1}{|c|}{ Destino após a remoção } & Total de famílias \\
\hline Perus & 237 \\
\hline $\begin{array}{l}\text { Municípios a Noroeste da RMSP (Franco da Rocha, Francisco } \\
\text { Morato, Caieiras, Cajamar) }\end{array}$ & 28 \\
\hline Zona Norte (Subprefeituras Casa Verde e Pirituba Jaraguá) & 8 \\
\hline Outros municípios do Estado de São Paulo & 7 \\
\hline Outros estados (Bahia, Maranhão, Minas Gerais, entre outros) & 3 \\
\hline Zona Sul & Put \\
\hline
\end{tabular}

Fonte: Sehab

Através desses dados fica evidente que a grande maioria buscou se manter em Perus. É muito provável que muitas dessas 237 famílias tenham se mudado de novo, por conta da instabilidade dada pelos preços imobiliários mais altos que a indenização da PMSP. Muitas vezes, acabam se alocando em moradias que não cumprem todos os quesitos legais e, assim, continuam sob risco de remoção. Essa situação de intensificação de mobilidade dos trabalhadores tem sido chamada de situação de “temporariedade permanente". A mobilização para os município a noroeste da RMSP indica o movimento de espraiamento da urbanização, especialmente em Franco da Rocha e Francisco Morato, cidades que vem crescendo muito nas últimas décadas e que apresentam preços imobiliários relativamente mais baixos, o que aponta que o padrão periférico, não foi superado, atinge uma nova escala ${ }^{209}$.

O projeto habitacional sustentável em questão atinge a materialidade diretamente ao deslocar centenas de famílias de suas moradas, o que significa uma perda material e subjetiva, potencialmente mais profunda para aqueles que praticaram a autoconstrução.

Aí eles iam e derrubava a casa, a máquina vinha... Foi duro, né? Foi duro, foi difícil, né? Porque vê sua casa que você sonhou construir com tanto esforço,

\footnotetext{
209 Enquanto a mancha urbana se expande em Francisco Morato e Franco da Rocha, o município de Caieiras, localizado entre essas duas cidades e Perus guarda uma série de terrenos vazios, para os quais se especulam uma série de empreendimentos.
} 
aí aquela "maquinona" vinha né? Quebrando a laje, destruindo tudo... ficou muito triste ali... teve gente que ficou com depressão ali... ${ }^{210}$

O caráter subjetivo da expropriação não deve ser ignorado. Além da depressão de alguns por ver a obra de uma vida destruída, é notável uma angustia geral de "viver esperando" a prometida casa, com a constante dúvida se vai ou não ser selecionado para o apartamento. Além disso, a expulsão da antiga casa gera perda de laços afetivos socioespaciais que, inclusive, são decisivos tanto para a inserção do sujeito na cidade e como para conseguir algum meio de obtenção de renda. A verdade é que a expulsão de sua casa é um processo traumático. A iminência de mais remoções também provoca apreensão e medo na área próxima ao Bamburral. Há um estado de pressão psicológica para essas pessoas que vivem uma constante dúvida: vale a pena gastar tempo e dinheiro na manutenção e melhoramento da casa ou logo virá uma remoção?

Podemos interpretar todo esse movimento material e subjetivo como integrante do processo de reestruturação produtiva e imobiliária. A história de vida de Dona Nilze e sua família é sintomática dos impactos dessas mudanças para os trabalhadores que migraram para São Paulo por conta de um emprego industrial e, recentemente, foram atingidos pela remoção, na lógica da cidade como negócio. Dona Nilze chegou a São Paulo vinda da Bahia, em 1962, com seu marido e quatro filhos. Foi morar na casa de seu irmão, que já havia em Perus. Dormiam na cozinha e no corredor. Seu marido já veio com emprego garantido na fábrica Santa Marina, na região da Água Branca. Logo compraram um lote no Jardim do Russo, que na época tinha poucas casas. Passaram a construir na vertente à direita do córrego das Laranjeiras, em um terreno grande e íngreme, onde havia, inclusive, grande área para plantação. Seu marido, que construiu toda a casa, aprendeu o ofício de pedreiro ao longo desse processo, o que, posteriormente, virou um meio de complementar a renda, através alguns de "bicos". Essa família chegou a morar seis anos sem água, nem luz. Usavam a água do córrego (suja) para a construção e tinham de buscar água limpa em uma mina no fim da rua. Nilze cuidava da casa, dos filhos e fazia crochê. Seus filhos foram crescendo e a divisão do terreno também: houve espécie de loteamento para os filhos e, também, para outros moradores que compravam os terrenos.

Silvio, um de seus filhos, foi um desses que ganhou um lote e ergueu sua casa, que foi demolida pela obra do Complexo do Bamburral. Levou 15 anos para construir a casa de dois andares. Segundo ele no processo de construção adquiriru três hérnias de

\footnotetext{
${ }^{210}$ Depoimento de Silmara.
} 
disco, por carregar peso. Quando foi desalojado tinha acabado de contrair uma dívida de R \$ 9.000 para abrir um comércio na parte de baixo da sua casa, mas como todos que conjugavam moradia e comércio no mesmo imóvel, teve direito apenas a receber uma única indenização. Optou pelo auxílio-aluguel. Ao ser removido, viu-se obrigado a voltar para casa dos pais - não atingida pelo projeto - com sua mulher e três filhos, aonde ainda espera que os apartamentos sejam construídos, enquanto espera administrar sua dívida.

Quando, nos anos 1970, o Estado desalojou diversas famílias, sem indenização justa, para a construção da Rodovia dos Bandeirantes começaram a surgir as favelas do “Complexo do Bamburral”. A necessidade de morar obrigou famílias a se instalarem no fundo do vale do córrego, ao lado do lixão. O morar é urgente, não pode esperar. Não se pode desconsiderar o papel dessa ação do Estado nos anos 1970, central para a formação desse espaço que agora passa novamente pela remoção, de modo a espoliar as pessoas, o que certamente redundará em novas remoções no futuro, configurando ciclos de expropriação.

Evidentemente, as condições de moradia de parte das famílias removidas do Bamburral eram perigosas e indesejadas para qualquer ser humano, tanto no que se refere aos riscos de deslizamentos e enchentes, quanto outras características que apontavam a insalubridade de habitar esse espaço. Como, por exemplo, o alto índice de tuberculose, constatado pela Subprefeitura no início dos anos 2000 ou a intensa convivência com ratos. Janaína relata que havia uma casa em que o enfermeiro, que tratava dos casos de tuberculose, se deparou com um gato que vivia amarrado em cima da cama, forma encontrada para espantar os roedores.

A necessidade de garantir a própria existência diante da pobreza impõe circunstâncias lamentáveis. Márcia, militante da Pastoral de Favelas da região do Jardim do Russo, relatou casos de situações extremas com as quais se deparou nas casas do fundo de vale: moradores que matavam ratos grandes e comiam; crianças que não enxergavam bem por causa de desnutrição; mães que logo de manhã colocavam os filhos fora de casa pra esquentar o corpo, que amanhecia gelado, devido às construções de madeirite.

Diante dos fatos expostos torna-se evidente que não se busca aqui advogar que famílias devam continuar morando em circunstância como essas. É inaceitável que em um mundo que produz tanta riqueza situações como essa ainda sejam tão comuns. No entanto, essa constatação não nos pode empurrar para a armadilha de crer que a solução 
urbanística ambiental proposta pela PMSP resolve esse problema ${ }^{211}$. Apesar de apresentar melhoras, sob algum ponto de vista, o projeto do Complexo do Bamburral como argumentado anteriormente, acaba por repor a expropriação em diversos níveis. A perda de parte da riqueza material, a pressão psicológica e o aumento nos custos de vida significam uma nova rodada de espoliação. Semelhante à ocorrida nos anos 1970 com a construção da Rodovia dos Bandeirantes, que originou parte da ocupação, agora removida. A contradição sobre a habitação dos trabalhadores não se resolve, apenas é deslocada espacial e temporalmente ${ }^{212}$.

\section{O ambientalismo espetacular: análise dos argumentos técnicos}

Os problemas referentes à ocupação das várzeas e vertentes do córrego das Laranjeiras seriam ambientais ou sociais? Qual a maior ameaça à sociedade: a falta de conectividade das matas ciliares ou a extrema pobreza? Para Eduardo Jorge e seu ambientalismo espetacular, retirar as pessoas que vivem nessas condições sub-humanas é um meio de combater o aquecimento global...

Os argumentos técnicos que justificam a remoção aparecem para a população local como uma enorme obscuridade, praticamente ininteligível. Buscaremos agora expor o argumento ambientalista enquanto integrante de uma ciência instrumental, a serviço de interesses específicos, que não coincidem com o "bem comum". Trata-se de uma tentativa de desconstruir um argumento tecnicista e o espaço concebido - portanto através de argumentos técnicos - que oculta e dissimula o real movimento no qual esse projeto está inserido. A constatação do atual ambientalismo como "representação de si mesmo" se torna mais evidente se analisarmos tecnicamente o projeto sustentável "Complexo do Bamburral".

As únicas categorias ambientais levadas em conta para sua elaboração foram o risco de deslizamento e a contaminação do solo. A densidade de drenagem do córrego das Laranjeiras e, também o índice pluviométrico da área, por exemplo, não foram considerados, o que soa estranho e pouco justificável para uma proposta que visa controlar as enchentes desse córrego.

Outro exemplo de categoria ambiental, fundamental, que o projeto não

\footnotetext{
${ }^{211} \mathrm{Em}$, ao menos duas tentativas, a PMSP retirou e desalojou os moradores das margens desse córrego. Ação que não se mostrou eficaz, visto que logo a área era ocupada novamente. Fato semelhante ocorreu na divisa com o Aterro Bandeirante. Essa fronteira foi rompida algumas vezes por ocupações, que mesmo sendo retiradas não desistiam. Como ressaltou Márcia: "A necessidade era muito grande, ia lá fazia a casa numa noite e no outro dia já estava morando".

${ }^{212}$ Esse assunto será retomado no texto subitem 4.3.
} 
apresenta é a permeabilidade do solo. Durante uma das audiências do Confema que debatia a realização do Complexo do Bamburral, o Conselheiro Alexandre questiona o alto grau de impermeabilização do solo que a Brasil Arquitetura propunha para essa área. Em resposta, os representantes da Sehab argumentam que a utilização de um material mais permeável sobre o solo geraria um maior custo e que, por isso, se optou pelo concreto comum nas áreas de passeio na margem do córrego (Confema, 2012). Aqui a contradição da espetacularizada "sustentabilidade" se escancara: o mais importante é ela se realizar enquanto representação, na prática se adota a solução economicamente viável, mesmo que isso seja o contrário do princípio ecológico. Criase, assim, uma aberração ecológica: um parque linear com solo impermeabilizado!

A medida tomada no Complexo do Bamburral para se (tentar) controlar as enchentes foi a retificação e canalização do rio, mantendo-o destamponado. Sobre essa medida, o conselheiro do Confema, Alexandre, de forma impotente questionou: "A gente acaba estudando na faculdade, que teoricamente, a canalização não é a melhor das opções, do ponto de vista, pelo menos, ambiental.” (Confema, 2012, p. 12) Tibiriçá, membro da Sehab, respondeu: "A maior contribuição dele (do córrego) é água que vem do aterro. Então a solução de canalização, se não fosse feita a canalização, ficaria muito difícil da gente dispor áreas para a construção de unidade habitacional, entendeu?" (Confema, p. 12, 2012). Ou seja, o "novo" paradigma ambientalista acaba adotando soluções antigas da engenharia sanitária, como a canalização de córregos. A superficialidade da abordagem sobre as enchentes nos leva a inferir que esse problema pode não ser solucionado pelo projeto urbanístico em construção. Ao que concluímos que essa intervenção habitacional sustentável não cumpre nem uma função ecológica e nem a da moradia social.

Debord (2015) assinala a impotência dos conhecimentos científicos acumulados para interferir sobre as contradições socioambientais em uma sociedade capitalista. Essa constatação descreve bem o conteúdo do diálogo entre os tecnocratas do Confema.

A impossibilidade já é, de fato, perfeitamente demonstrada por todo o conhecimento científico separado, que não discute mais do que o fracasso; e os paliativos que poderiam, se os aplicássemos resolutamente, o fazer recuar ligeiramente. Uma tal ciência não pode mais do que nos acompanhar rumo a destruição do mundo que a produziu e que a mantém; mas ela é forçada a fazê-lo com os olhos abertos. Ela mostra, assim, em um grau caricatural, a inutilidade do conhecimento sem uso. (Ibid.)

Do ponto de vista da vegetação e do paisagismo, o projeto do Bamburral também nada apresenta. Para ser mais correto, ele se vale de diversos desenhos espetaculares, com áreas gramadas e árvores floridas, em meio a pessoas circulando 
felizes (Figura 8). Aspectos como reconstituição de flora e fauna, sucessão ecológica ou ecologia de paisagens são desconsiderados por esse projeto "sustentável". O fato de não haver nenhum aprofundamento intelectual sobre a questão da vegetação é muito sintomático da espetacularização do ambientalismo em Perus ${ }^{213}$. Isso porque, a argumentação que embasa a existência de parques lineares urbanos parte do pressuposto que esses corredores de vegetação ciliar podem garantir a conectividade entre as manchas de vegetação e, consequentemente, favorecer o aumento da biodiversidade e a reconstituição ecológica.

O objetivo desses questionamentos não é o de argumentar que o problema dos projetos urbanísticos ambientais é que eles são tecnicamente mal feitos. Nenhuma solução técnica será capaz de resolver as contradições da sociedade capitalista. Se buscou aqui - a partir de alguns critérios que a ciência geográfica oferece desmistificar a lógica que regeu esse processo de remoções, pautado por um tecnicismo espetacular, nesse caso de cunho ambientalista. O caráter tecnicista se evidencia pelo uso de alguns conhecimentos que passam longe do senso comum, que são tidos como verdades absolutas e, assim, dirigem o processo de urbanização, muitas vezes contendo um frágil (e/ou falso) embasamento conceitual e científico. Nos cabe perguntar quais os critérios que têm sido utilizados para avaliar a qualidade ambiental? Qual sua real relevância? E ainda mais importante, quem está sendo afetado por esses projetos? No limite, qual a cidade que está sendo proposta por esses projetos de cunho ambiental? "Proteção ambiental, afinal de contas, em benefício de quem? Quanto aos problemas ambientais, quais são mais prioritários, e do ponto de vista de quem? E quanto ao risco ambiental, quem e como os define?" (SOUZA, 2014). Para que e para quem serve essa “cidade ambientalmente sustentável” que vem sendo construída?

\section{Figura 9 - Imagens projetadas de como seria o Conjunto Habitacional do Bamburral}

\footnotetext{
${ }^{213}$ Também no projeto do Parque Linear do Ribeirão Perus não há nenhuma referência a esses temas.
} 


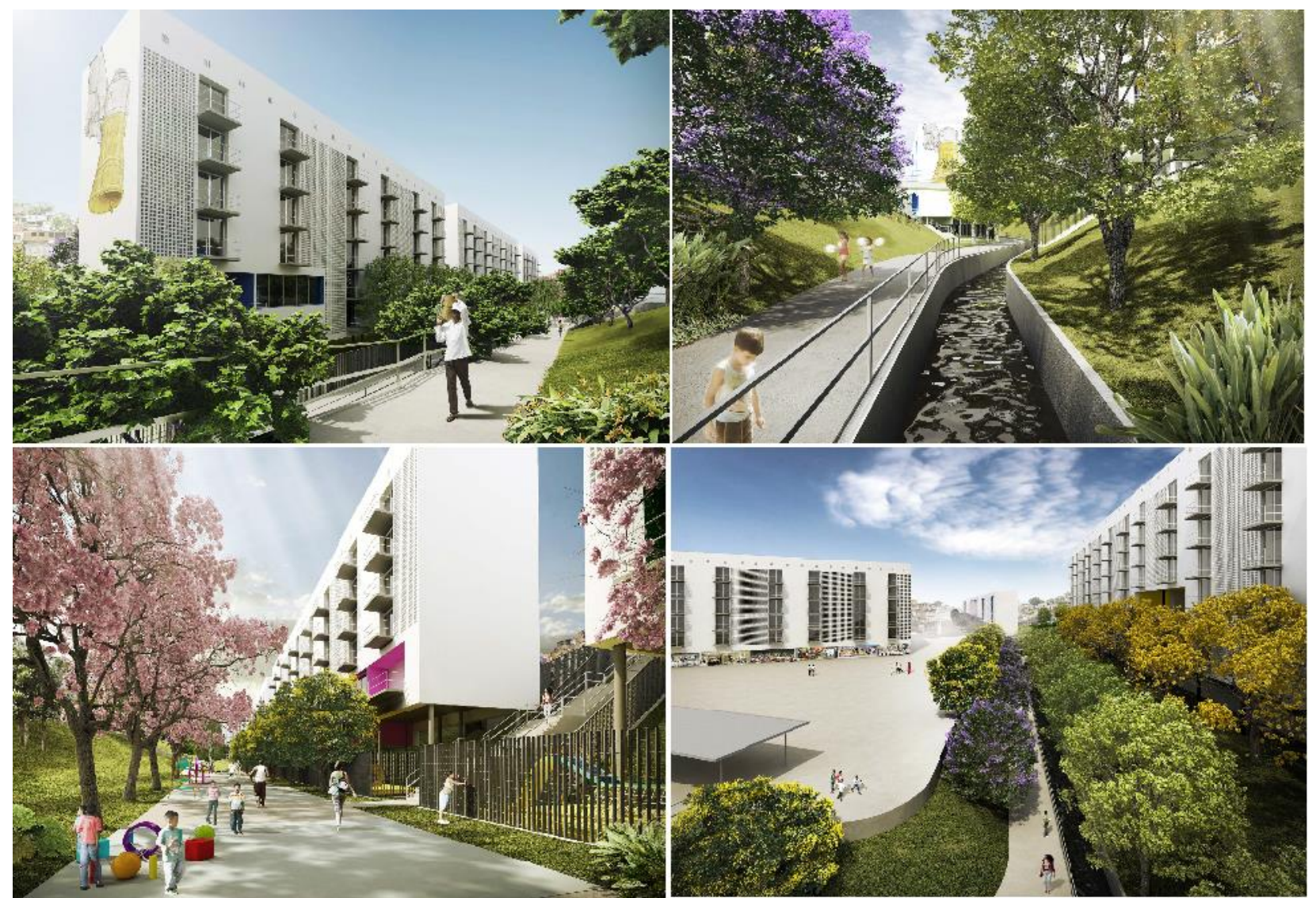

Fonte: Brasil Arquitetura, 2011.

\subsection{Apontamentos sobre o Plano de Bairro do Distrito de Perus}

Outra controversa destinação para o dinheiro dos créditos de carbono da PMSP foi a contratação do escritório Urbe Planejamento Urbanismo e Arquitetura ${ }^{214}$ para a realização de um Plano de Bairro para o Distrito Perus. O montante gasto para a realização desse Plano foi de R\$ 587.278,36.

O objetivo desse subcapítulo é expor algumas análises sobre as propostas do Plano de Bairro de Perus, que virou o Projeto de Lei (PL) no 331/2011 apresentado à Câmara Municipal pelo vereador José Police Neto ${ }^{215}$ (então presidente da casa) que, entretanto, não chegou a ser aprovado - na verdade, não foi sequer colocado em regime de votação. Buscaremos esboçar algumas problematizações sobre as propostas inseridas nesse Plano e, ao mesmo tempo, abrir uma reflexão sobre a própria razão de ser desse documento. Também procuraremos ampliar a investigação sobre o urbanismo sustentável, tendo em vista que das três propostas analisadas essa é a que busca planejar

\footnotetext{
${ }^{214}$ Ligado ao professor Cândido Malta, da Faculdade de Arquitetura e Urbanismo da Universidade de São Paulo (FAU-USP).

${ }^{215} \mathrm{Na}$ época, filiado ao PSDB (Partido da Social Democracia Brasileira). Hoje (2018), ainda vereador, filiado ao PSD (Partido Social Democrático).
} 
os mais diversos níveis do cotidiano, não só a moradia ou o lazer. Trata-se de uma análise de como a tecnocracia opera a partir da ideia de "sustentabilidade". Essa análise busca desvendar algumas estratégias envolvidas no processo de expansão e reprodução do espaço urbano em Perus, identificando os atores sociais interessados nesse processo.

\section{Aspectos gerais de um projeto "sustentável" de reestruturação imobiliária}

Nesse item apresentaremos aspectos gerais da análise do PL 331/2011, para nos itens a seguir, realizarmos apontamentos mais específicos sobre os detalhes desse projeto urbanístico.

O Plano de Bairro é um mecanismo previsto desde o antigo Plano Diretor Estratégico (PDE) da cidade (lei $N^{o}$ 13.885, 2004). Consiste em um nível de planejamento urbanístico, na escala do distrito, ou seja, mais específico que o Plano Regional Estratégico (PRE) que abrange a área da subprefeitura. Apesar da existência desse mecanismo estar descrita em lei, há muitos anos, Perus foi o primeiro distrito a ter um projeto dessa escala realmente elaborado ${ }^{216}$.

Supostamente, o instrumento do Plano de Bairro teria que estar em consonância com o PDE e o PRE. Sendo assim, seria um instrumento que permitiria maior nível de detalhamento no planejamento urbano, em teoria, refinando o entendimento das questões mais cotidianas do distrito. Segundo seus entusiastas, Essa seria a principal virtude desse instrumento. Na prática, porém, o Plano de Perus buscou alterar algumas diretrizes do planejamento maior, ao propor mudanças no zoneamento e intervenções urbanísticas, como é possível se observar no PL 331/2011. Ou seja, esse instrumento inicialmente previsto no PDE para discutir ações de complementação da infraestrutura, calçamento, limpeza acabou se transformando - no caso do PL apresentado à Câmara em uma proposta de redefinição do uso do solo.

Evidentemente, essa característica de possibilitar propostas de alteração na regulação urbanística, torna esse mecanismo interessante para os proprietários de terras e para as empresas do setor imobiliário, já que estes podem propor mudanças nas diretrizes do planejamento e do zoneamento, através de outra instância de decisão que não é o PDE e nem a LPUOS (popularmente conhecida como "lei de zoneamento"). No sentido empregado pelo PL 331/2011, um Plano de Bairro pode se valer de ferramentas semelhantes ao mecanismo da Operação Urbana Consorciada (OUC).

\footnotetext{
${ }^{216}$ O novo Plano Diretor de São Paulo, Lei no 16.050, aprovada em 2014 mantém o conceito de Plano de Bairro como instrumento, com algumas pequenas alterações.
} 
Antes de iniciar a análise do projeto em si, é necessário fazermos uma observação. É possível afirmar que, por mais que o Plano de Bairro de Perus não tenha sido aprovado, seu projeto ainda reverbera e deixa rastros $^{217}$. E esse não é um caso isolado. Em alguns fragmentos específicos da metrópole, é possível observarmos uma grande quantidade de projetos urbanísticos que se sobrepõem e, independentemente de se realizarem ou não, cumprem um papel importante para a economia política do espaço (LEFEBVRE, 2008a). Em outras palavras, a existência de inúmeros projetos - muitas vezes sobrepostos e até contraditórios - que não se realizam, ou que estão em compasso de espera, não é um fato casual. Há que se ressaltar um caráter especulativo no planejamento: diversos planos urbanos se "autorealizam", isto é, realizam-se somente no nível da tecnocracia e não na materialidade do espaço Funcionam como uma sinalização ao mercado imobiliário de promessa de trabalho futuro incorporado ao solo, a partir da ação do Estado. Aparentemente autonomizados, originados de visões fragmentárias, descolados de uma noção de totalidade, os impactos vislumbrados por cada plano se somam ou se anulam, estabelecem relações e repercutem no cotidiano, em maior ou menor grau ${ }^{218}$.

Feita essa ressalva, focalizaremos a investigação em alguns pontos específicos do Plano de Bairro, que dialogam com nossas hipóteses e que revelam algumas das estratégias contidas no projeto. Essa análise se dará partir do conteúdo do PL 0331/2011 e de dois livros explicativos do Plano ${ }^{219}$ (SALGADO et al., 2011; idem, 2012).

Evidentemente os interesses imobiliários envolvidos não saltam aos olhos em uma primeira leitura do PL 331/2011. Observando desavisadamente esse Plano ele pode ser lido como uma verdadeira política pública de um Estado de Bem Estar Social, digna dos países centrais do capitalismo em seus anos de ouro. Uma ampla pesquisa sobre os dados populacionais, carências infraestruturais atuais e terrenos vagos do distrito de Perus foi realizada por uma equipe contratada pelo escritório Urbe. A partir desses dados se listou e planejou a construção de diversas infraestruturas e equipamentos

\footnotetext{
${ }^{217}$ Isso é notável, por exemplo, em conversas com funcionárias da subprefeitura e com o próprio exSubprefeito de Perus, Sérgio Moraes, em julho de 2016, que tratam esse Plano como uma "joia" que não deve ser esquecida. O próprio autor do PL, o vereador Police Neto, continua a frequentar o bairro e a se vangloriar do vanguardismo desse projeto.

218 Anos após o PL do Plano de Bairro sequer ter sido votado na câmara, o vereador Police Neto organizou publicações para divulgar o conteúdo desses projetos. Em um delas - "Plano de Bairro: Perus em transformação" (Salgado et al., 2012) - os autores afirmam que as mudanças de zoneamento levantadas no PL 0331/2011 devem ser entendidas como proposições de diretrizes para os futuros PDE e PRE.

${ }^{219}$ O Plano de Bairro foi elaborado em 2008, encaminhado à Câmara Municipal em 2011, e virou livro em 2011 e em 2012.
} 
urbanos, inclusive já vislumbrando um aumento populacional e a demanda do futuro, geradas pelos futuros empreendimentos imobiliários que Perus receberia. Alguns exemplos de novas construções previstas pelo Plano de Bairro de Perus são: 24 Unidades Básicas de Saúde (UBS) e Assistências Médicas Ambulatoriais (AMA); diversas escolas (desde creches até o ensino médio), alguns clubes, dois hospitais, uma universidade e um equipamento cultural semelhante a um SESC.

No PL 0331/2011 é levantado o valor de investimentos públicos necessários para a construção e manutenção de todos esses equipamentos. Segundo a proposta do PL a administração pública (notadamente a PMSP) teria que investir aproximadamente $\mathrm{R} \$$ 2,6 bilhões para realizar todas as construções propostas. Além disso, essas novas construções teriam um custeio adicional de manutenção anual de aproximadamente $\mathrm{R} \$$ 357 milhões. Todos esses valores foram calculados pelos autores do Plano de Bairro em 2008. Contudo, praticamente, nenhum meio de financiamento dessas obras é previsto ${ }^{220}$.

Em uma situação hipotética, em que todos esses equipamentos previstos fossem materializados ${ }^{221}$, evidentemente haveria uma gigantesca valorização imobiliária na região, o que consequentemente geraria um processo de gentrificação, de modo que os contemplados pelas benesses do Plano de Bairro seriam uma parcela minoritária dos atuais moradores de Perus. É relevante e curioso salientar que, embora tenha sido elaborado por reconhecidos urbanistas, a questão da valorização imobiliária (e a subsequente gentrificação) não aparece em sequer uma linha do PL 0331/2011, e nem mesmo nos dois livros de publicados. Tampouco a questão da moradia para os mais pobres é abordada nesse instrumento de planejamento que supostamente prevê todos os níveis do cotidiano. Essas ausências são opções sintomáticas feitas pelos tecnocratas.

No entanto, o Plano de Bairro se apresenta como uma "solução para todos os problemas", elaborado de maneira "participativa 222 ". Contudo, em uma leitura mais atenta, se percebe que esse instrumento do planejamento está em consonância com as ideias de expansão urbana e de reprodução do espaço, associado aos negócios logísticos e novos empreendimentos imobiliários residenciais. Isso se evidencia, pois há nele

\footnotetext{
${ }^{220}$ Curiosamente há uma única obra que tem seu meio de financiamento previsto pelo Plano de Bairro. Trata-se de um anel viário proposto em torno do bairro (mais adiante analisaremos esse caso específico). ${ }^{221}$ É difícil crer que a PMSP realize, tão cedo, todos investimentos previstos no Plano de bairro, especialmente no atual momento histórico em que as seguidas gestões do Estado inclinam-se em maior ou menor grau, para as políticas orientadas pela ideia de "Estado mínimo".

222 “(...) foi à oferta de uma fórmula mágica para os moradores pobres da região, uma verdadeira Alavanca de Arquimedes que retiraria, finalmente, o Distrito de sua condição periférica: o Plano de Bairro do Distrito de Perus” (Rizzi, 2011b, p. 40).
} 
propostas imobiliárias para praticamente todos os grandes terrenos vagos de Perus, inclusive com alteração de zoneamento e aumento do potencial construtivo, além de recomendação de reformulação de espaços já consolidados. Os pequenos terrenos vagos também foram reservados para supostamente receber os equipamentos públicos $\operatorname{prometidos}^{223}$. A questão da "sustentabilidade", além de aparecer no Plano através de seu caráter espetacular e vazio, faz parte de uma promessa de "embelezamento" do bairro e controle dos espaços vazios - por meio de um "sistema de áreas verdes", baseado no conceito de parque linear.

Rizzi interpreta que a proposta do Plano de Bairro está diretamente associada à construção do Rodoanel, de modo que esse instrumento urbanístico seria um meio de buscar controlar a ocupação do espaço, para evitar ocupações de pessoas pobres:

A idéia de Plano de Bairro para o Distrito de Perus sai de um simples plano de complementação de infra-estrutura básica, de requalificação de calçadas, de limpeza pública como coleta seletiva e paisagismo, para o incrível instrumento de poder no qual em vez de se discutir "projetos de bolsões residenciais propostos pela comunidade local”, a população local será convocada e "congelar áreas" para futuras escolas, sem que se diga claramente, como tais equipamentos devam ser planejados conjuntamente com demais órgãos públicos responsáveis. Seus propositores não esclarecem por exemplo, que no Distrito de Perus, o interesse em congelar áreas, isto é, de impedir a expansão urbana local, vai no sentido de proteger terrenos adjacentes ao Rodoanel Mário Covas, possíveis focos de urbanização precária. (RIZZI, 2011b, p.43, destaque do autor)

Em nossa opinião não se trata apenas de "impedir a expansão urbana", trata-se controlá-la, e a realizar selecionando usos, de acordo com os interesses e o ritmo do mercado imobiliário. Em resumo, o PL 0331/2011 pode ser interpretado como um meio de controle dos espaços vazios e uma promessa de adensamento e expansão urbana, capitaneada por alguns negócios imobiliários logísticos e habitacionais, onde cada vazio do bairro assumiria uma função, tornando o aproveitamento do espaço mais produtivo. Todo esse projeto de reestruturação imobiliária - que não é outra coisa senão a capitalização do urbano projetada por tecnocratas - aparece com uma espécie de "maquiagem populista", calcada nas promessas de diversas construções destinadas à saúde, educação, lazer, cultura, transporte etc. Construções essas tão desejadas para qualquer habitante da periferia da metrópole de São Paulo.

Evidentemente que essas inovações urbanísticas vêm acompanhadas de uma especulação sobre as possibilidades futuras de uso dos terrenos da região, o que se traduz em uma especulação sobre os preços das terras e dos imóveis. Originado por um

${ }^{223}$ O PL instituiria um zoneamento específico para esses terrenos: a Zona de Reserva de Área. Para mais detalhes sobre essa nomenclatura ver PL 0331/2011, artigo $7^{\circ}$, paragrafo $2^{\circ}$, inciso I. 
capital fictício - os créditos de carbono - o Plano de Bairro de Perus se configura como uma promessa de trabalho futuro na região, que abre uma gama de possibilidades especulativas para os envolvidos na produção do espaço. De modo que, esse capital fictício (associado aos outros vários projetos de intervenção urbanística) cria a expectativa de ampliação do volume dos capitais fictícios oriundos das propriedades de terras em Perus, graças à ação dos tecnocratas do espaço. O investimento de créditos de carbono em "projetos urbanísticos sustentáveis" se torna um trunfo para Perus na concorrência entre os lugares pelo capital fictício. Observemos em detalhe algumas propostas do Plano de Bairro para a melhor compreensão dessas hipóteses.

\section{O processo "participativo" de elaboração do Plano de Bairro de Perus}

O Plano de Bairro de Perus - que tem como "pais", o vereador José Police Neto e o urbanista Candido Malta Campos Filho - parte do conceito chave de Unidade Ambiental de Moradia, cuja característica principal seria a de "ilha de tranquilidade" (SALGADO et al., 2011, p. 11). O Plano divide Perus em dez Unidades Ambientais de Moradia (UAM), uma espécie de unidade de vizinhança estruturada sobre preceitos ambientalmente saudáveis. Quais seriam esses preceitos não é possível saber ao certo, pois não há uma descrição explícita nos documentos analisados do caracteriza o termo "ambiental" em se tratando de unidades de moradia. A impressão que se passa é o "ambiental" enquanto um signo publicitário que se quer atrelar ao bairro, mas que na prática tem pouca significância. Cada UAM seria como um bairro completo, quase que autossuficiente no que se refere a serviços públicos e comércios mais básicos. Na Figura 3 é possível ver a divisão do distrito em dez UAM, e também algumas das principais proposições do Plano de Bairro. 
Figura 10 - Principais propostas de expansão e reestruturação urbana do Plano de Bairro de Perus

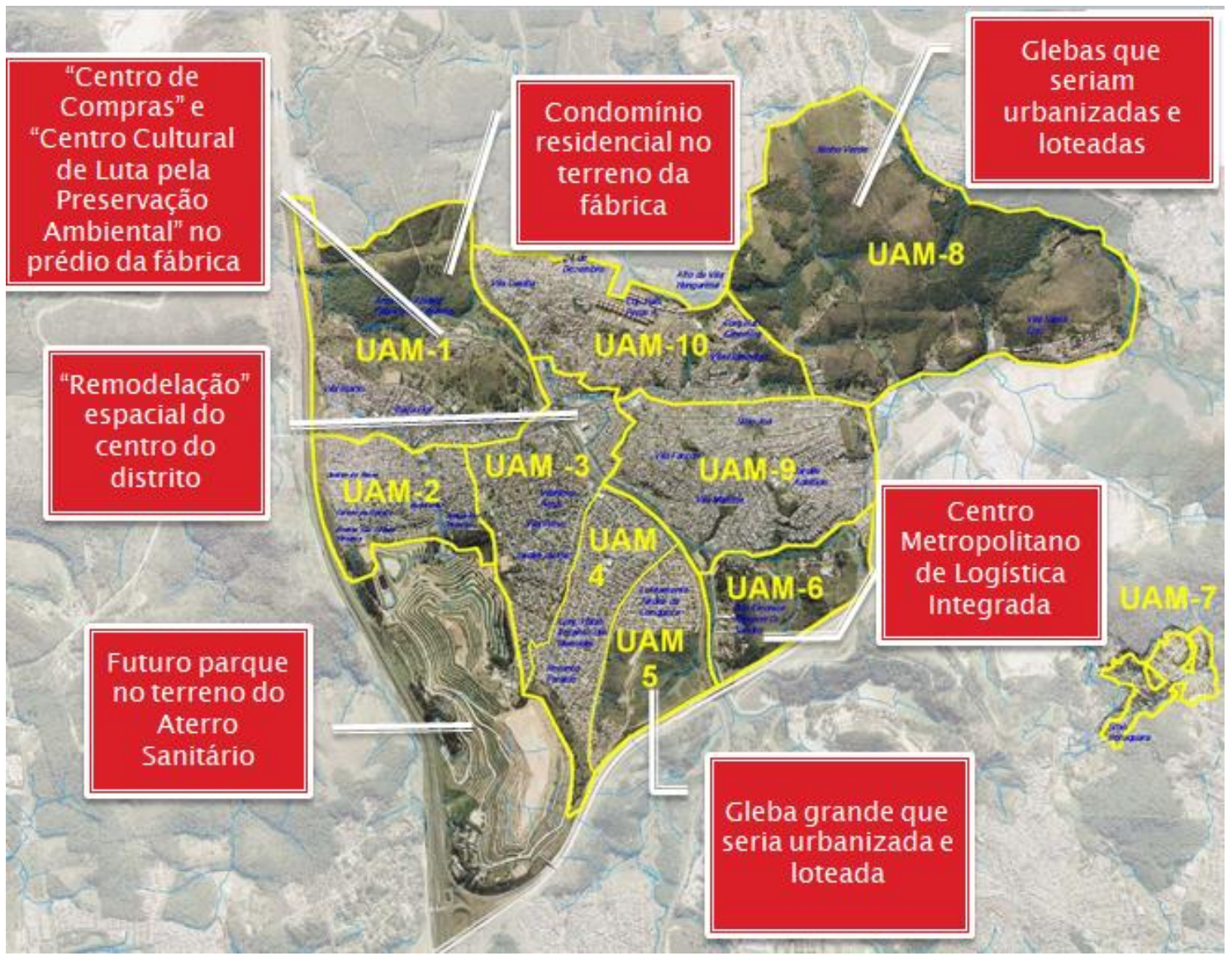

Fonte: Elaborado pelo autor com base em Urbe Planejamento Urbanismo e Arquitetura (2008)

Os autores do projeto do Plano de Bairro se vangloriam de esse instrumento, ao aproximar a escala do planejamento, conseguir que a população participe mais diretamente dessa atividade, impondo suas vontades nas diretrizes do planejamento, tirando assim os tecnocratas e políticos do protagonismo de pensar a cidade. $\mathrm{O}$ discurso, que prega o planejamento e construção da cidade a partir das necessidades e vontades de seus habitantes, soa interessante aos ouvidos mais progressistas e, inclusive, atende a demandas históricas dos movimentos que lutam pelo direito à cidade ${ }^{224}$. Entretanto, essa noção também pode ser pensada sob a lógica da decomposição, ou seja, uma ideia, $a$

${ }^{224}$ Há que se ter consciência que a realização plena dessa premissa é inviável, do ponto de vista institucional, pois contraria frontalmente a lógica da sociedade capitalista, que não é outra senão a busca pela valorização do valor. Sendo assim, a esperança de que, institucionalmente, se proporcione a oportunidade de construir uma cidade voltada para atender as necessidades e desejos dos cidadãos é vã, sobretudo em um contexto em que a produção do espaço urbano adquire maior centralidade para a reprodução capitalista. Isso não anula a pertinência de se organizarem movimentos sociais que se estabelecem como parâmetro de luta a realização de um planejamento popular da cidade, contudo - como destaca Lefebvre ao que se referir à luta política institucional pelo "Direito à Cidade" - é importante haver consciência das limitações dessa via "lucidamente utópica” (LEFEBVRE, 2008b, p. 114). 
priori, combativa e contra sistêmica, que é incorporada como um novo instrumento de manutenção do antigo status quo, que agora se apresenta sob uma (mera) aparência “participativa". É notável, tanto no projeto de lei quanto nas publicações posteriores, que há uma negligência em se divulgar uma descrição detalhada, sobre o método e o processo, de como foi a participação social.

Desse modo, nos dedicaremos a agrupar as poucas informações sobre a construção "participativa" do Plano de Bairro para contrapô-las aos depoimentos de moradores ${ }^{225}$ que viveram o período desse processo, para realizar uma análise crítica. $\mathrm{O}$ processo "participativo" do Plano de Bairro se iniciou em 2008 com assembleias na Subprefeitura de Perus e no CEU Perus. A existência dessas reuniões também foi justificava pela suposta a ideia de essas reuniões seriam espaços onde a população poderia dirigir a aplicação dos recursos do dinheiro dos créditos de carbono (ver Figura 11). O que era uma farsa, pois a decisão de como gastar esses recursos foi tomada dentro dos gabinetes da PMSP.

Figura 11 - Modelo de faixa que foi exposta no bairro para divulgar uma das assembleias do Plano de Bairro de Perus

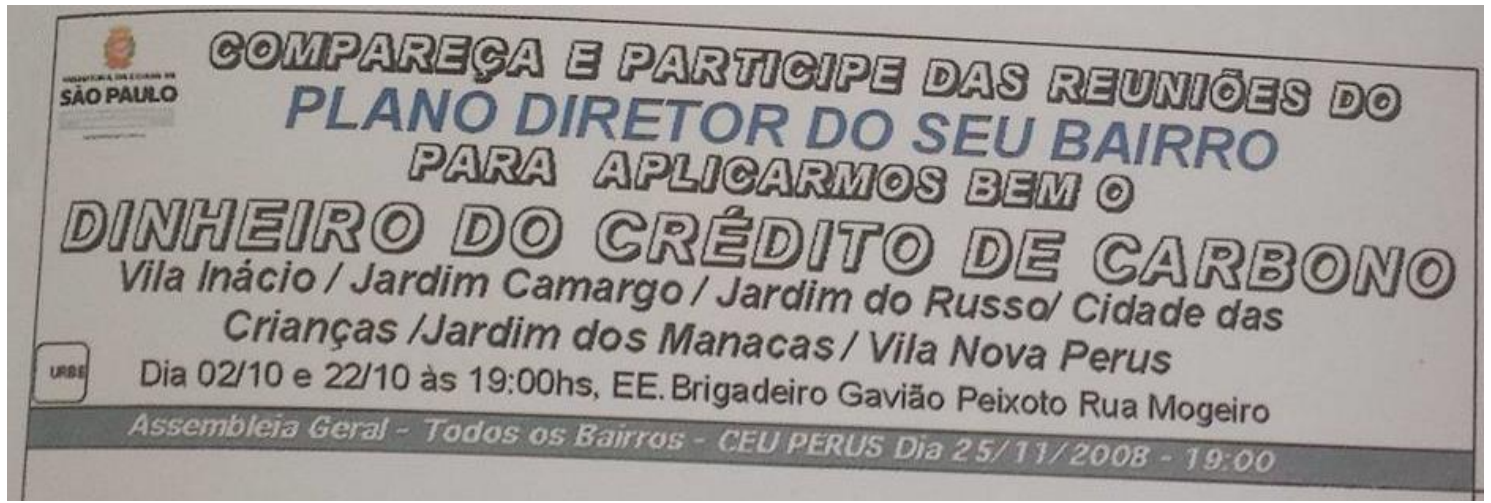

Fonte: Salgado et al., 2011, p. 81

Em um segundo momento, formaram-se equipes de pesquisa de campo para a realização de um diagnóstico do bairro. É interessante notar os dados populacionais obtidos por essa pesquisa. Segundo ela, o distrito de Perus contava, em 2008, com

\footnotetext{
${ }^{225}$ A maior parte dos moradores entrevistados disse que não compareceu as reuniões do Plano de Bairro e, a maioria deles sequer sabia da existência desse Plano. RIZZI (2011b, p. 45) analisa a falta de participação dos moradores de Perus nesse processo e atesta: "Contudo, esse metafórico "protagonismo de segundo plano" encontrado nas audiências públicas realizadas após o fechamento do Projeto MDL Aterro Bandeirantes, não parece sui generis, pelo fato deste conter uma postura já tradicional. Por exemplo, no ano de 2009, houvera denúncias de que essas audiências públicas foram realizadas sem divulgação e nas quais "só convidados da prefeitura participaram" (Portal de Perus, 25/07/2009). Há denúncias nas quais se diz que a Subprefeitura de Perus omitiu informações para a comunidade local, novamente, sob a sintomática postura de convidar "somente pessoas selecionadas" (Portal de Perus, 04/05/2009). Até mesmo as audiências sobre a discussão do Plano de Bairro não foram publicamente divulgadas, ficando restritas somente a especialistas, muito embora a Prefeitura ressaltasse repetidamente a importância da participação dos "munícipes" moradores de Perus (Portal de Perus, 30/06/2008)."
} 
111.122 habitantes (Urbe Planejamento Urbanismo e Arquitetura, 2008) - cerca de 30.000 pessoas a mais que o registrado pelo censo em 2010. Além disso, há a projeção de um acréscimo populacional de 121.725 habitantes (Ibid.), quando todos os lotes vazios forem ocupados, ou seja, segundo o projeto do Plano de Bairro os grandes terrenos vagos abrigariam mais que o dobro da população atual, totalizando 231.847 pessoas.

Esses e outros dados do diagnostico foram apresentados à população em dez assembleias, em cada uma das UAM. Somente após essas reuniões, o projeto do Plano de Bairro, do escritório Urbe, foi apresentado aos moradores. O que se realizou depois e que os autores chamaram de "processo participativo" foi, basicamente, a votação das propostas apresentadas pelos tecnocratas, através de um questionário em que os moradores tinham que responder se concordavam ou não com as propostas. Ou seja, a "participação" era referendar ou não as propostas que já vinham prontas ${ }^{226}$. Todas as propostas apresentadas foram aprovadas. Não foi encontrada a informação de quantas pessoas participaram dessas votações. Outro quesito "participativo" foi que no questionário também havia perguntas sobre quais investimentos eram prioritários para a população local. Supostamente, essa ordem de prioridades eleita seria a ordem de elaboração das obras. Os equipamentos prioritários eleitos foram os de saúde e, os equipamentos de educação infantil, em segundo lugar.

O então morador de Perus, Leonardo, participou de diversos encontros de "construção" do Plano de Bairro. Segundo ele, mesmo contando com um número razoável de participantes, a população não foi às reuniões e, os que foram, não estavam preparados para discussões daquele tipo. Apenas os mais interessados, e com alguma formação prévia sobre o assunto, puderam achar interessante as assembleias de apresentação do Plano, mesmo assim, em uma posição muito mais de contemplativa do planejamento do que, realmente, de participação. Esse depoimento é revelador da ideia de decomposição e espetacularização do "planejamento participativo" que coloca a população em uma posição passiva e tediosa, mas que aparece em um momento seguinte como uma representação de uma atividade de cooperação inovadora.

\footnotetext{
226 Foram vinte perguntas realizadas. A seguir alguns exemplos: "Concorda que Perus tenha 8 UBS+AMA para a demanda atual e 16 UBS+AMA para a demanda futura?"; "Concorda com a implantação de um Hospital Geral em Perus?"; "As áreas de risco devem receber intervenções urgentes que possibilitem a melhoria e estabilidade desses locais?" (URBE PLANEJAMENTO URBANISMO E ARQUITETURA, 2008).
} 
Nessas assembleias também se reivindicou o uso do dinheiro dos créditos de carbono para a construção do tão clamado hospital em Perus. Essa era (e ainda é) uma discussão de longa data em Perus. Os habitantes engajados politicamente tinham uma proposta que consistia em utilizar os recursos dos créditos de carbono para construir esse um hospital. Segundo cálculos da época, um hospital com padrões mínimos (capacidade para 200 leitos) custaria, aproximadamente, $\mathrm{R} \$ 50$ milhões, quantia para a qual a arrecadação da PMSP com créditos de carbono seria mais do que suficiente. Os moradores, inclusive, apresentaram um espaço para o hospital, que seria uma parte do terreno da antiga fábrica de cimento.

Entretanto, a PMSP se valeu da interpretação de que os recursos dos créditos de carbono teriam que ser investidos, exclusivamente, em obras de recuperação ambiental, como forma de compensação pelos danos que o Aterro Sanitário Bandeirantes causou ao meio ambiente durante os anos em atividade. Argumento que foi rebatido pela população local através do questionando de que o Lixão trouxe muitos danos para saúde humana em Perus. Por fim, prevaleceu a premissa da PMSP de gastar o montante dos créditos de carbono apenas com o "meio ambiente". Fato que demonstra que na "gestão democrática" dos recursos e dos instrumentos de planejamento há uma força desigual na tomada de decisões.

Sem dúvida, uma discussão mais profunda sobre o que significam os processos de planejamento urbano participativo faz-se necessária e outros trabalhos já o fizeram como, por exemplo, Maricato (2011). Limitaremos-nos aqui a criticar esse formato adotado no caso do Plano de Bairro, que se traveste de participativo, mas que, em verdade, é um simples referendo de um saber tecnocrático, que disfarça as questões essenciais em jogo com o Plano, através de uma enxurrada de promessas de equipamentos de bem estar social - que são economicamente inviáveis de serem realizadas, pelo menos não na conjuntura atual.

É sintomático que todas as propostas apresentadas pela empresa Urbe tenham sido aprovadas, como se a participação popular se limitasse a referendar o que os iluminados da academia já conceberam previamente sobre seu bairro. Reafirma-se, nesse exemplo, que o grau de instrumentalização das ciências que planejam o espaço é tamanho, que acaba gerando uma "linguagem à parte", que pouco comunica às pessoas. Sem dúvida, esse formato de participação tem sua razão de ser, visto que, em meio às propostas que todo morador periférico de São Paulo sonha que se realize, também foram "democraticamente" referendadas - de forma sorrateira - mudanças no zoneamento, 
remoções de favelas, um plano urbanístico específico para a construção de um novo condomínio residencial, entre outros projetos que corroboram com a capitalização do urbano nessa região. A apresentação dos argumentos técnicos para a população se faz, propositadamente, de forma confusa, especialmente no que se refere às questões mais centrais em jogo. "A minha sensação de morador é que a gente não conseguiu fazer parte da construção da forma como poderia ter sido empregando dinheiro (dos créditos de carbono)", afirmou Leonardo. Entretanto, nas publicações dos políticos e urbanistas, autores do projeto, há uma exaltação de como esse processo foi participativo e de como deveria ser uma referência para o planejamento em geral.

\section{$O$ "sistema de áreas verdes": remoções e gentrificação}

O projeto do Plano de Bairro de Perus reúne uma série de características que o qualificam como um exemplo completo do que caracteriza o planejamento urbano ambiental, na maneira pela qual esse conceito vem se constituindo nos últimos anos: parte de uma ideia confusa, contraditória e decorativa de natureza; baseia-se em uma concepção de natureza externa a sociedade; origina-se de uma visão fragmentária da realidade; as questões técnico-ecológicas são menos importantes que os interesses econômico-políticos para elaboração dos projetos; é custeado por um mecanismo financeiro internacional (créditos de carbono); seu financiamento é mediado por instituições supranacionais; prevê o "embelezamento" do espaço via remoção de moradores de menor poder aquisitivo; subjuga a luta por "direito à cidade" à recuperação ambiental; potencializa a capitalização do espaço urbano ${ }^{227}$.

Se a ideia de UAM é apresentada como conceito chave do projeto, o chamado "sistema de áreas verdes" é outro elemento estruturador do Plano de Bairro, esse propõe a construção de uma série de novas praças e parques em Perus. Os autores do projeto partem de uma de visão determinista do espaço sobre a ação humana, para justificar essas ações sustentáveis, proclamando a "vocação turística-ambiental" do bairro. Em diversos momentos do Plano transmite-se a ideia de que a ocupação humana deve ocorrer de acordo com a condição de seus elementos naturais.

${ }^{227}$ É importante esclarecer que não consideramos os projetos, designados como "sustentáveis", como sendo partes de um todo homogêneo. Sem dúvida, existem diferentes qualidades e intencionalidades nesses projetos. Há sim alguns avanços trazidos pelas políticas ambientais urbanas. Porém vemos que o aproveitamento econômico desse tipo de política tem sido muito mais significativo que o ecológico. Inclusive, no geral, é possível afirmar que o planejamento urbano ambiental, tal qual vem sendo executado em São Paulo, é um fato que contribui para agravar os problemas ambientais. 
Figura 12 - Desenho feito pelo urbanista Candido Malta para o Plano de Bairro de Perus

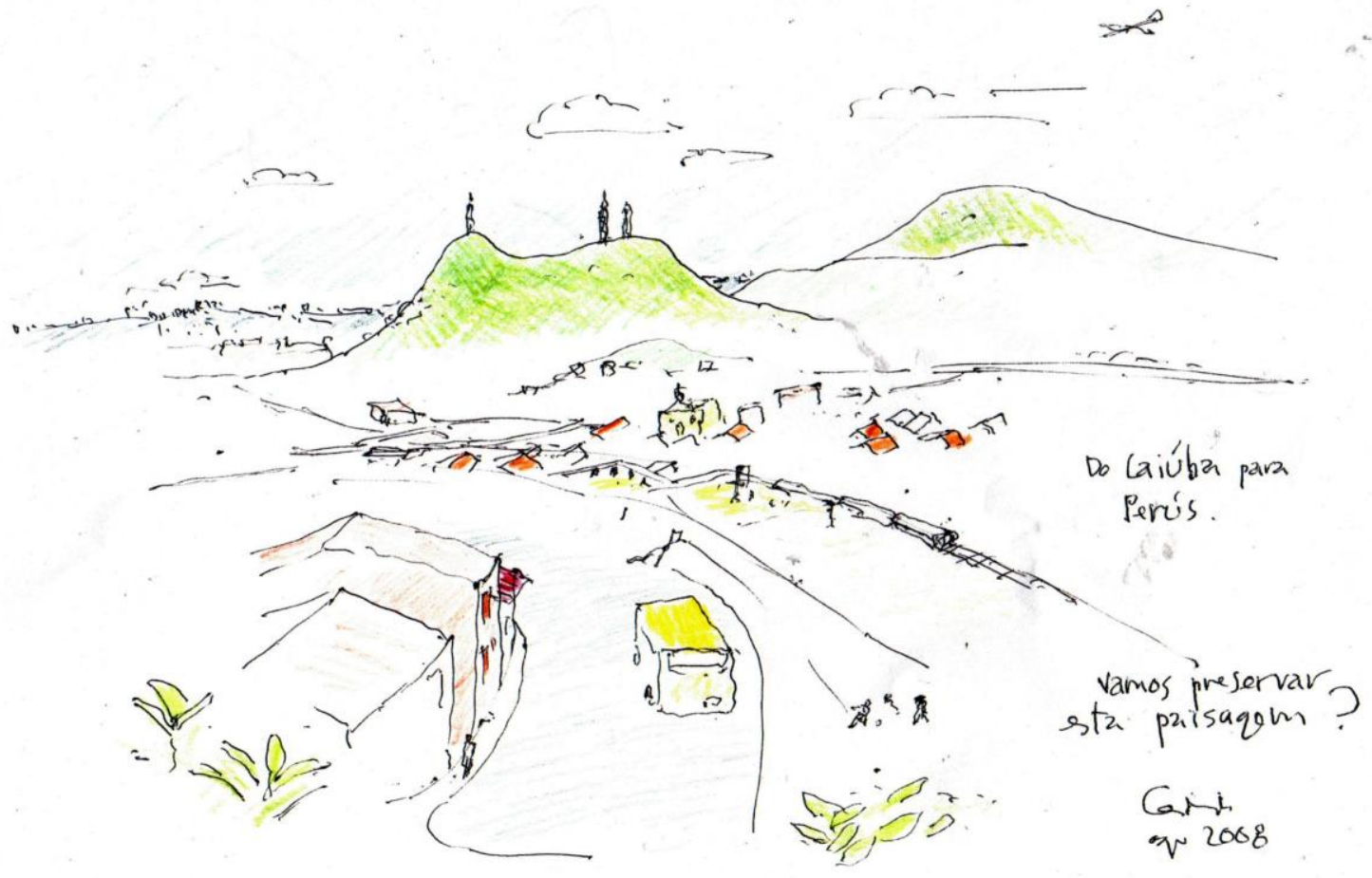

Fonte: Urbe (2008)

Essa imagem representa bem o que seria a "nova mercadoria imobiliária verde". Há uma projeção de "cenário sustentável" onde as construções (em sua maioria de baixo padrão construtivo) são omitidas desse desenho que destaca o verde. Essa é uma representação metafórica do urbanismo sustentável que tem como característica o alto índice de remoções e a pouca preocupação com moradia dos mais pobres. $O$ autor ainda escreve no desenho "vamos preservar esta paisagem?", o que soa quase que irônico e atesta para a característica de controle do uso do espaço desse urbanismo.

Com muita vegetação e altitudes variando entre 740 e $800 \mathrm{~m}$, propiciando uma diminuição das temperaturas médias anuais em relação ao centro de São Paulo, em Perus por volta dos $9,5^{\circ}$, o clima local é um dos seus atrativos pela qualidade do ar e temperatura amena. Some-se a isso o próprio sítio, com muitas colinas e vales onde se destaca na paisagem o Pico do Jaraguá, referência geográfica e visual da cidade. E qual bairro da cidade pode se dar ao luxo de ter dois enormes parques como o Parque Anhanguera e o Parque Linear? (SALGADO et al., 2012, p. 32, destaque nosso)

Essa última pergunta, que destaca o "luxo" de estar próximo a áreas verdes, indica que o "ambiente" sugere a ocupação desse espaço a partir dos novos produtos imobiliários, associados ao discurso de "volta à natureza". O processo fetichista de personificar o espaço urbano através de uma "vocação", faz parte do esforço do Plano de Bairro para convencer os capitais financeiros de que é possível extrair uma renda fundiária extraordinária em Perus, através de "negócios imobiliários verdes". A exaltação da média térmica diferenciada do centro da cidade e do aspecto visual que o 
relevo oferece são meios de enfatizar uma oportunidade de investimento incomum para o espaço metropolitano.

Além disso, esse determinismo geográfico que norteia o Plano de Bairro, se analisado em detalhe, revela um obscuro plano de remoção das frações mais pobres da população - que são aquelas que ocupam os fundos de vale e as encostas mais íngremes dos morros - sem viabilizar, claramente, outra maneira destes permanecerem no bairro. Ou seja, segundo esse determinismo, os fundos de vales têm que ser ocupados por parques lineares e, não, pelas atuais moradias. Dessa forma, se propiciaria um ambientalmente decorativo, palatável ao consumo imobiliário o que, provavelmente, culminaria em um aumento nos preços imobiliários. Esse aumento estaria pautado entre outras coisas - pelo estabelecimento de uma ideia de que Perus contém uma característica exclusiva na metrópole dada sua privilegiada posição em meio a tantas áreas verdes, combinada a proximidade relativa ao centro da cidade, e ainda com fácil acesso importantes rodovias.

Como destacado no capítulo um, o potencial aumento dos preços imobiliários em Perus é fruto, em grande medida, de um aumento na renda fundiária, dada pela exclusividade dessa região - no conjunto da metrópole - em relação ao usufruto de parques urbanos (presentes e futuros) e áreas verdes, associada à construção do Rodoanel. Desse modo, a profusão, por Perus, de mais áreas verdes seria uma forma de elevar ainda mais a renda fundiária, através do controle das ocupações irregulares de terras.

De maneira geral, o sistema de áreas verdes (ver Mapa 7) que complementam as zonas de proteção ambiental existentes, prevê mais parques lineares nas áreas lindeiras aos rios, um novo parque na área do Aterro Bandeirantes e a implantação de novas praças - especialmente em áreas de encosta íngreme ${ }^{228}$. As intervenções urbanísticas ambientais analisadas anteriormente - a "urbanização" da favela Bamburral e o Parque Linear do Ribeirão Perus - já estavam sendo projetadas quando se iniciou a elaboração do Plano de Bairro, que incorporou essas propostas. Segundo este Plano, os habitantes removidos pelos projetos previstos por esse instrumento terão prioridade no reassentamento em equipamentos de moradia que forem construídos no bairro. Apesar dessa menção, não há, no Plano, indicação nenhuma acerca da construção de

\footnotetext{
${ }^{228}$ O PRE de 2004 já previa um programa de implantação de praças. Plano de Bairro o endossou e somou novos projetos. De fato o dinheiro dos créditos de carbono foi utilizado para recuperar algumas praças e construir outras.
} 
equipamentos de moradia de interesse social. Simplesmente a questão da moradia não é prevista nesse instrumento do planejamento.

O Plano de Bairro alega que o planejamento ambiental deve ser estruturado em torno do Parque Linear Perus, seguindo a mesma lógica de intervenção ao propor outros três pequenos parques lineares no bairro: um no córrego do Recanto dos Humildes; outro no córrego da Mina; e o terceiro na continuidade do córrego das Laranjeiras ${ }^{229}$.

Os dois primeiros córregos foram canalizados (e mantidos destamponados) em 2007, no programa de "urbanização" de favelas da Sehab, que envolvia calçamento das ruas e saneamento básico. Nessa ocasião, o poder público tentara emplacar um parque linear no Recanto dos Humildes, o que não foi possível devido à resistência dos moradores que não aceitaram um projeto que envolvia tantas remoções. Por fim se realizou um projeto que removeu 105 famílias $^{230}$ e criou um corredor de passeio impermeabilizado, ocupando menos de cinco metros da várzea desse córrego. Hoje, segundo depoimento de moradores, esse é um lugar de passagem e de consumo e venda de drogas, por conta da não circulação de automóveis e de ser um lugar mais "escondido". A intervenção realizada também não assegura que as habitações não sejam atingidas por inundações do córrego ${ }^{231}$.

A parte mais à jusante do córrego da Mina recebeu intervenção semelhante por parte da Sehab que, segundo essa secretaria não envolveu remoções ${ }^{232}$. A área à montante do córrego não foi "urbanizada", mas há projetos para que isso ocorra em

\footnotetext{
${ }^{229}$ Um quarto parque linear também é projetado para uma área, atualmente, sem uso na Vila Fanton.

230 “(...) desse grupo, 17 tiveram suas casas reformadas e foram morar com aluguel pago pela Prefeitura até a conclusão das obras, 32 foram morar em unidades do Conjunto City Jaraguá (CDHU), 24 receberam a verba para compra de casa em outro local público e 32 receberam verba de atendimento." Retirado de $<$ https://www.prefeitura.sp.gov.br/cidade/secretarias/habitacao/noticias/?p=4041> Acessado em: 18 de setembro de 2017.

${ }^{231}$ Travassos analisou essa intervenção e também assegurou: "tais habitações não estão livres de serem inundadas, sob chuvas intensas ou por quaisquer impedimentos à vazão dos corpos-d'água pelos canais pelo contrário, estão bastante suscetíveis a isso." (TRAVASSOS, 2010, p. 179)

${ }^{232}$ Sobre esse córrego moradores revelaram um caso de como a PMSP atua no controle do uso do espaço com vistas a reprimir ocupações de trabalhadores, ao mesmo tempo, em que negligencia a questão da moradia. Segundo depoimento de Rodrigo, ao lado do córrego canalizado havia um terreno, utilizado para jogar entulho. Um dia, a PMSP retirou todos resíduos acumulados ali e, em seguida, o terreno foi ocupado por famílias para moradia. Rodrigo afirma que os novos habitantes colocaram a faixa na ponte sobre córrego: "melhor ocupado por pessoas que por lixo". Ainda, segundo ele: "Não deu um mês e tiraram as casas, limparam o terreno. Aquele terreno nunca faziam nada. Aí de repente eles (a PMSP) tiveram a grande ideia de fazer um campinho de futebol (...) pra gastar o mínimo possível e ocupar aquele espaço de um modo que as pessoas fiquem relativamente felizes (...) poderia muito bem ser um centro cultural, porque o terreno é ótimo, uma localização privilegiada". O controle do uso do espaço via equipamentos de lazer fica evidente para a moradora Laura: "Eles (a PMSP) fizeram e agora tá cheio de mato, porque eles fizeram só pra dizer que tem alguma coisa ali e ninguém ocupar".
} 
breve $^{233}$. É nessa área da bacia hidrográfica - na sua vertente direita - que está se consolidando a mais recente ocupação informal de Perus, como destacado no primeiro capítulo.

Não obstante os córregos da Mina e do Recanto dos Humildes terem sido "urbanizados" e já existir uma espécie de parque linear aí, o Plano de Bairro propõe que se aprofunde o caráter ecológico dessas intervenções. Para isso propõe que os cursos d'água sejam "renaturalizados".

Ao longo dos córregos Recanto do Humildes e da Mina estão propostos dois parque lineares. É importante para a qualidade desses parques que os córregos sejam renaturalizados. (...) Hoje, a canalização do córrego da Mina está concluída e a obra do parque já foi licitada (SALGADO et al., 2012, p. 90-91, destaque nosso).

Esse conceito não é bem explicado pelos autores. A utilização da ideia de "renaturalizar" córregos pelo Plano de Bairro seria puramente espetacular e ideológica ${ }^{234}$ ? Dentro da ecologia, há distintas interpretações sobre esse conceito, mas que, em geral, partem do princípio de "restauração ecológica". Essa pode ser entendida "como o processo de alterar propositalmente um local para restabelecer seu ecossistema original" (TRAVASSOS, 2010, p. 70). Entre os ecologistas, a controvérsia gira em torno da possibilidade de se realizar essa ação em uma área urbana. Por isso, uma definição mais "flexível" para "renaturalização" de um rio urbano seria: "Objetiva estabelecer um sistema hidrológico e morfológico variado, sistemas que sejam dinâmicos e estáveis, capazes de servir de suporte a ecossistemas saudáveis e biodiversos, mas sem referência a um sistema preexistente.” (Ibid., p.71). Mesmo essa definição seja menos "purista", caso ela seja implantada realmente no Recanto dos Humildes e no córrego da Mina seria causadora, sem dúvidas, de um elevado número de remoções, o que agravaria o problema habitacional.

O terceiro parque linear novo proposto pelo Plano de Bairro seria uma continuidade do parque do Complexo do Bamburral, mais a jusante no mesmo córrego das Laranjeiras. O projeto de urbanização da favela Bamburral prevê um Parque Linear que vá desde o Aterro Sanitário até o fim dessa favela, já o Plano de Bairro prevê sua expansão até a Rodovia dos Bandeirantes (ver mapas 6 e 7). Também para esse córrego se prevê a "renaturalização": "O Córrego Laranjeiras deverá sofrer um processo de

\footnotetext{
${ }^{233}$ Ver, por exemplo, em: < http://www.arq-urb.com/projetos-arquitetura/projetos-urbanizacao/complexocorrego-da-mina/ > Acessado em: 11 de setembro de 2018.

234 A partir do conceito de produção da natureza, trabalhada no capítulo 2, pensar em termos de "renaturalização" seria um contrassenso. No entanto, essa ideia é frequentemente utilizada no planejamento urbano ambiental.
} 
renaturalização e no trecho ao longo da Av. Dr. Silvio de Campos até o início da favela Bamburral junto a Rua Silveirânia deverá se transformar em um parque Linear" (PL 0331/2011, artigo $34^{\circ}$, inciso VII).

Para a realização desse projeto seriam necessárias mais diversas remoções, pois esse rio passa por uma área densamente ocupada, inclusive, pela favela Beija Flor. Todavia, o projeto não divulga uma estimativa de quantas remoções, nesse caso, seriam necessárias. É preciso enfatizar que esse é o único dos Parques Lineares novos propostos pelo Plano de Bairro em que se apresenta um mapeamento de como seria esse novo projeto, o que sugere que esse seria uma prioridade para essa proposta urbanística.

Além disso, no Plano de Bairro está discriminada uma série de outras áreas tidas como "prioritárias para urbanização", sem maiores detalhes do como e nem quando ocorreria essa reurbanização É sintomático não haver mais informações sobre esses projetos visto que, provavelmente, envolverão remoções. Dentre essas áreas é possível identificar que grande parte delas são favelas, como é o caso da Cidade das Crianças.

Diante desse quadro de propostas e realizações de parques lineares e urbanização de favelas ${ }^{235}$ podemos notar que as obras atingem, sobretudo, as áreas ocupadas por pessoas com menor renda. Diante desse fato, é mais polêmica a ausência no Plano de Bairro de uma proposta sistematizada de fazer com que as pessoas removidas (mais pobres) possam ficar no bairro.

Essa abstenção nos permite afirmar que o "conceito" de natureza, contido no Plano de Bairro, engloba a ideia de que as frações mais pobres da classe trabalhadora não têm o direito de habitar esse bairro. Essa "expulsão" dos que habitam os fundos de vale é justificada por uma espetacular harmonia do "reencontro" do cidadão urbano com a "natureza primeira perdida". O frágil embasamento técnico-ecológico desse projeto nos leva a crer que esse "reencontro" é uma representação - e portanto, falso - o que torna mais visível seu papel ideológico: o de tentar eclipsar a concepção de direito à cidade através da sustentabilidade ambiental, promovendo assim uma maior capitalização do espaço urbano.

\footnotetext{
235 "A urbanização de favelas é considerada uma pauta historicamente progressista também pelos movimentos organizados em torno dos direitos dos favelados e ativistas da luta pela reforma urbana. No entanto, o que nossa pesquisa revela é que mesmo em tais projetos de urbanização tem havido remoções de famílias com violações de direitos. (...) remoções cujos motivos, inclusive, são passíveis de questionamento e poderiam eventualmente ser evitados ou acomodados no interior do próprio assentamento." (ROLNIK et al., 2017, p. 16) É notável que grande parte dos projetos de urbanização de favelas contemplam projetos de intervenção sobre corpos d'água, de modo que - pautados pelo ideal de "sustentabilidade" - há neles ideais tributárias do paradigma de parque linear.
} 
Esse suposto "reencontro" seria desfrutado sobremaneira pelos novos habitantes de Perus, as mais de 120 mil pessoas que o Plano de Bairro prevê que ocupem os grandes terrenos vazios, depois de edificados e comercializados. Contraditoriamente, os novos negócios imobiliários diminuiriam a área verde do distrito.

De forma resumida, o Plano de Bairro parte das condições "naturais" de Perus que na verdade são produzidas socialmente - para determinar como e quem deve ocupar esse distrito, demonstrando uma visão seletiva e eugênica da "sustentabilidade", fundada em contraditórios processos de "renaturalização".

\section{Reprodução e expansão urbana: reestruturação do centro, novo anel viário e a “vocação” logística}

Nesse subtítulo abordaremos as propostas do PL 0331/2011 de reprodução do espaço construído de Perus e também as de expansão para áreas livres (ver Figura 10). Em seu diálogo velado com o mercado financeiro-imobiliário o Plano de Bairro de Perus indica os terrenos vagos que podem ser alvos de investimentos do setor privado. Mais do que isso ele propõe a construção pelo Estado de novas estruturas espaciais para garantir a maior rentabilização dessas áreas.

Um ponto estratégico do Plano de Bairro é, sem dúvida, a sua proposta de reestruturação do viário do bairro, associada à refuncionalização de algumas áreas. Historicamente, o centro de Perus se construiu, nas áreas do entorno da estação de trem. As avenidas Silvio de Campo e a Fiorelli Peccicacco (e as ruas próximas a elas) abrigam os principais comércios e serviços da região. Note-se que se trata de estabelecimentos típicos de um subcentro periférico na atual metrópole de São Paulo com a presença de agências dos principais bancos, conhecidas lojas de eletrodomésticos, um restaurante internacional de fast food, pequenos comércios, empresas familiares, serviços públicos, vendedores ambulantes, entre outros estabelecimentos. A proposta do Plano de Bairro é realizar intervenções urbanísticas no entorno desse eixo. Segundo o próprio Plano, a ideia é preparar "esse corredor comercial para melhor atender seu público atual, prevendo seu desenvolvimento futuro" (SALGADO et al., 2012, p. 34).

Isso porque para a realização dos novos produtos imobiliários "verdes", além de ser ter uma boa vista para a (suposta) natureza, é necessário ter fácil acesso à praticidade da vida urbana. Ou seja, conforme se realize a reestruturação urbana em Perus, seu espaço terá que estar adequado às necessidades de consumo de classes médias urbanas, 
além de precisar atender, com serviços complementares, os centros logísticos de entorno.

O PL 0331/2011 prevê três áreas de intervenção urbanística no eixo das avenidas Silvio de Campo e Fiorelli Peccicacco, cortando o distrito como um todo de leste a oeste, desde a Avenida Raimundo Pereira de Magalhães até a Rodovia dos Bandeirantes ${ }^{236}$. Além de mais duas intervenções urbanísticas no perímetro de entorno do distrito.

A principal área de reestruturação é a Área de Intervenção Urbanística-2, projeto que prevê o "redesenho do eixo central de Perus" (SALGADO et al., 2012, p. 34). Essa parte da proposição do Plano de Bairro nos remete ao discurso da competitividade entre as cidades que propaga a ideia de que os lugares têm que se preparar (através de ações do poder público) para receber novas empresas, para atrair o chamado setor terciário avançado e, assim, gerar desenvolvimento econômico. Alguns autores desmitificaram esse discurso ao demonstrar que, como plano de fundo e cerne da readequação dos espaços, está a expectativa do capital financeiro imobiliário em se valorizar e receber maiores ganhos fundiários, através da reprodução do espaço, facilitada pela intervenção pública.

A população de Perus, assim como outras potenciais áreas de "novas centralidades", vive essa longa expectativa de receber empresas no bairro. A readequação do centro do bairro passa pela ideia de que a modernização espacial poderia trazer maior competividade para esse espaço em relação a outros. Essa concepção - que é comum em outros projetos urbanísticos também - se baseia em uma representação mimética do que se constituiu como centro financeiro da metrópole de São Paulo, o eixo Faria Lima - Berrini. Essa reprodução faz parte das estratégias tecnocráticas que buscam oferecer portfólios publicitários para o mercado financeiro imobiliário comprar pedaços da cidade, através de projetos urbanísticos que contenham alterações de zoneamento, de potencial construtivo, promessas de obras públicas de modernização das infraestruturas etc. Para esses capitais a reestruturação espacial é uma necessidade, pois as construções antigas, afixadas ao solo, já não exercem o potencial de captação de renda fundiária.

\footnotetext{
${ }^{236}$ Essa intervenção também objetiva a readequação do viário já existente e se soma a proposta de construção de um novo anel para automóveis, que circularia todo o distrito (Figura 14), completando o projeto de readequação viária proposto pelo Plano de Bairro, que permitiria uma circulação de automóveis mais intensa.
} 
Contudo, apesar dessa representação, há uma noção implícita no Plano de Bairro que os produtos imobiliários possíveis para Perus são diferentes daqueles presentes no quadrante sudoeste da metrópole. Os valores de uso que se propõe construir por lá são centros logísticos e condomínios de classe média, produtos financeiro-imobiliários, que em geral, têm menor rentabilidade se comparados à construção de shoppings centers, edifícios para o setor terciário avançado ou condomínios de alto padrão, como atestado por Botelho (2008). A busca de valorização do valor pelo do capital financeiroimobiliário se adequa às diferentes realidades espaciais metropolitanas, com diferentes produtos imobiliários.

A destruição (criativa) e reprodução do espaço do centro de Perus caracteriza explicitamente o projeto de reestruturação espacial. O Plano de Bairro prevê uma série de novas construções de alto padrão nesse espaço: a modernização da estação ferroviária ${ }^{237}$; uma praça suspensa sobre essa estação; um edifício garagem; um novo terminal de ônibus; um novo teatro; uma faculdade; e uma ponte prédio que passaria por sobre os trilhos do trem e abrigaria apartamentos comerciais (ver Figura 13). O desenho do projeto de "novo centro" tem uma arquitetura arrojada, modernista e espetacularizada, que difere bastante do padrão das construções atuais dessa área. Inclusive, é interessante notar que na representação gráfica, utilizada pelo escritório Urbe Planejamento Urbanismo e Arquitetura, a área do Recanto dos Humildes é ocultada. A área que deveria ocupar na imagem foi substituída pela cor branca, como se ali houvesse um espaço vazio, como é possível ver na Figura 13 (destaque em vermelho). Pode-se inferir que, implicitamente, está colocada a ideia de que essa ocupação não faz parte da "nova imagem de Perus" que o Plano quer transmitir, através do centro renovado.

É notável que uma das funções dessa representação do Plano de Bairro é o de buscar atrelar, "colar", uma nova identidade, mais moderna, para Perus, buscando "resituar" esse lugar na metrópole de São Paulo, não mais como um bairro dormitório periférico, mas como uma "nova centralidade". O meio mais utilizado, até o presente momento, para realizar essa transposição de caráter de Perus, são os diversos projetos urbanísticos e, sobretudo, a profusão de imagens espetacularizadas que eles propagam.

Evidentemente, essas novas construções projetadas no centro de Perus se realizariam sobre uma área de urbanização consolidada. Não há nenhuma citação no PL

\footnotetext{
${ }^{237}$ Proposta que desconsidera que esse edifício é tombado pelo patrimônio histórico.
} 
0331/2011 sobre o que aconteceria com as atuais construções existentes que teriam que ser demolidas, e tampouco, sobre o destino de quem mora/usa esses espaços. Evidenciase um processo de reducionismo ${ }^{238}$ da realidade que caracteriza o urbanismo ao tratar o espaço como um vazio a ser preenchido, desconsiderando a prática espacial estabelecida. Além disso, a valorização imobiliária, associada às inovadoras construções, certamente intensificaria um processo de gentrificação. Como ressaltado anteriormente, fato que não foi problematizado pelo Plano de Bairro.

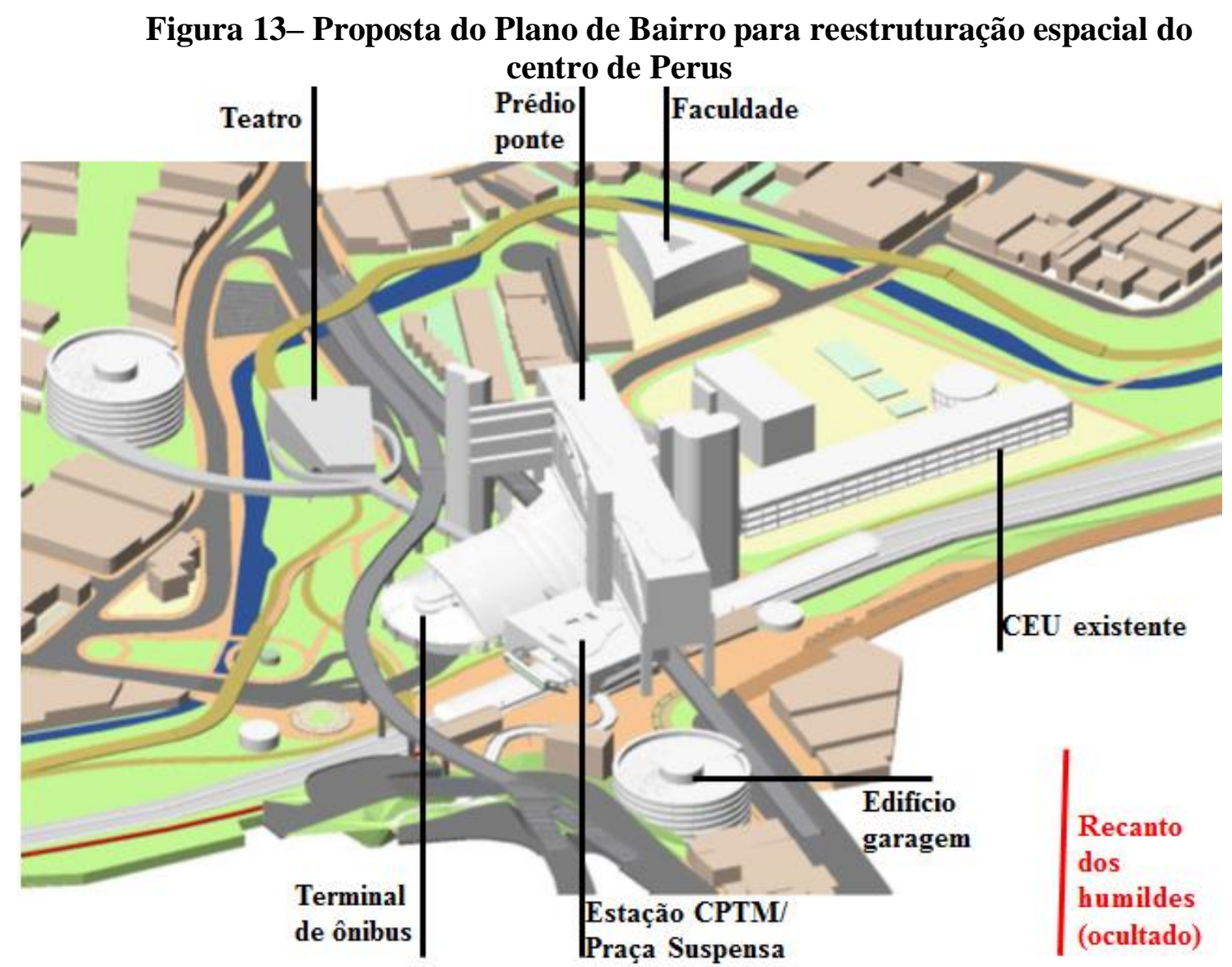

Fonte: Elaborado pelo autor, com base em Urbe Planejamento Urbanismo e Arquitetura (2008)

Para a reestruturação da área já construída, soma-se a essa proposta de intervenção pública através de novas construções, uma expressiva requisição de mudança de zoneamento em áreas já ocupadas das UAM 1, 2, 3, 8, 9 e 10. O PL transformaria em Zonas Corredores de uso misto diversas ruas desses espaços,

\footnotetext{
${ }^{238} \mathrm{O}$ espaço instrumental propõe um achatamento das dimensões que compõe a realidade social: "tudo se reduz ao solo, ao plano, ao desenho, à projeção numa superfície, daí o aplainamento e a planitude" (LEFEBVRE, 2008a, p.142), empobrecendo, assim, as múltiplas possibilidades que o espaço social pode ou poderia conter. Faz-se necessário, portanto, criticar o reducionismo do planejador que de forma autoritária impõe práticas da cotidianeidade, contribuindo para a reprodução das relações sociais de produção.
} 
autorizando-se a verticalização de até cinco pavimentos, o maior aproveitamento do terreno, entre outras características (PL 0331/2011, artigo 8º incisos VI e VII).

Outra importante proposição do Plano de Bairro é apresentada como uma solução para o trânsito de automóveis interno ao bairro: a construção de um anel viário que percorra todo o perímetro do bairro. Note-se que há realmente um problema de congestionamento de automóveis no distrito. Um dos motivos para esse fenômeno é a existência de pedágios nas rodovias Bandeirantes, Anhanguera e no Rodoanel, o que faz com que os moradores dos municípios ao norte de Perus, que trabalham na cidade de São Paulo, evitem os altos custos de trafegar pelas rodovias e optem por desviar por dentro do bairro de Perus, gerando trafego intenso, sobretudo nas horas de pico ${ }^{239}$. Embora, o Plano de Bairro não cite a problemática dos altos preços dos pedágios, ele apresenta o novo anel como uma solução viária (Figura 14).

Analisando com cuidado, nota-se que a intencionalidade dos propositores vai além de uma solução para o congestionamento de automóveis. A justificativa explicitada no PL 0331/2011 para a construção do anel, no perímetro do núcleo urbanizado é que, dessa maneira, se evitaria remoções geradas pelo alargamento das principais vias existentes ${ }^{240}$ - o que seria demasiado caro, pois elas abrigam os maiores comércios e serviços de Perus.

Assim como o projeto de construção do Rodoanel propõe uma nova escala para os negócios de urbanização na metrópole, também a construção do anel viário de Perus propõe um aumento de escala para a produção do espaço neste bairro. Isto é, essa obra seria uma essencial para redefinir a situação geográfica de certos terrenos "afastados" do centro de Perus que, dessa forma, teriam sua acessibilidade e, consequentemente,

\footnotetext{
${ }^{239}$ Nos primeiros meses de funcionamento do Rodoanel trecho oeste, em 2002, não se cobrava pedágio ainda para trafegar por ele. Os moradores relatam que, nesse breve período, o trânsito melhorou muito no bairro, diminuindo o fluxo de caminhões e de carros de outras cidades. Para os próprios comerciantes das avenidas foi bom, pois permitiu que os clientes parassem o carro com mais tranquilidade para consumir. Entretanto, quando foram lançados os pedágios no Rodoanel, o tráfego voltou a ser muito intenso. Durante o processo de elaboração "participativa" do Plano de Bairro, o tráfego pelos moradores era mencionado pelos moradores de automóveis nas audiências. Diante da proposta do anel viário apresentado pelo escritório Urbe, os habitantes de Perus questionaram essa solução por ser muito "faraônica", o que lhes causava uma desconfiança de que não se realizaria tão cedo. Apresentaram, em contraposição, a ideia de se interromper a cobrança de pedágio no Rodoanel novamente, porém essa proposta não foi incorporada ao PL, mantendo-se a proposta original da Urbe.

${ }^{240}$ O texto do PL 0331/2011 não explicita, mas observando os mapas de projeção futura é possível notar que o desenho do novo anel viário de Perus está projetado sobre um trecho de área ocupada na parte norte do distrito (UAM 10, Vila Caiuba), de modo que a realização dessa obra também implicaria em remoções diretas. É notável que o terreno vizinho dessa área ocupada está vazio, de modo que se o traçado do anel fosse deslocado alguns metros para norte seria possível evitar essa remoção.
} 
seus preços redefinidos - através de uma maior capacidade de extração de renda fundiária.

Observamos que esse novo anel viário foi projetado para passar por todos os grandes terrenos vagos do entorno de Perus, que são pelo menos quatro. Esse fato indica a tendência de expansão da urbanização nesse distrito, e o aumento da escala dos negócios urbanos que se pretende para essa parte da metrópole. Para todos esses terrenos o plano de bairro prevê projetos ${ }^{241}$ (Figura 10). Não é demais ressaltar que a estimativa do PL 0331/2011 é que, com a realização dos novos condomínios residenciais nesses terrenos e o adensamento do centro, haveria um acréscimo populacional de 121.725 pessoas.

Figura 14 - Proposta de novo Anel Rodoviário no entorno do distrito de Perus

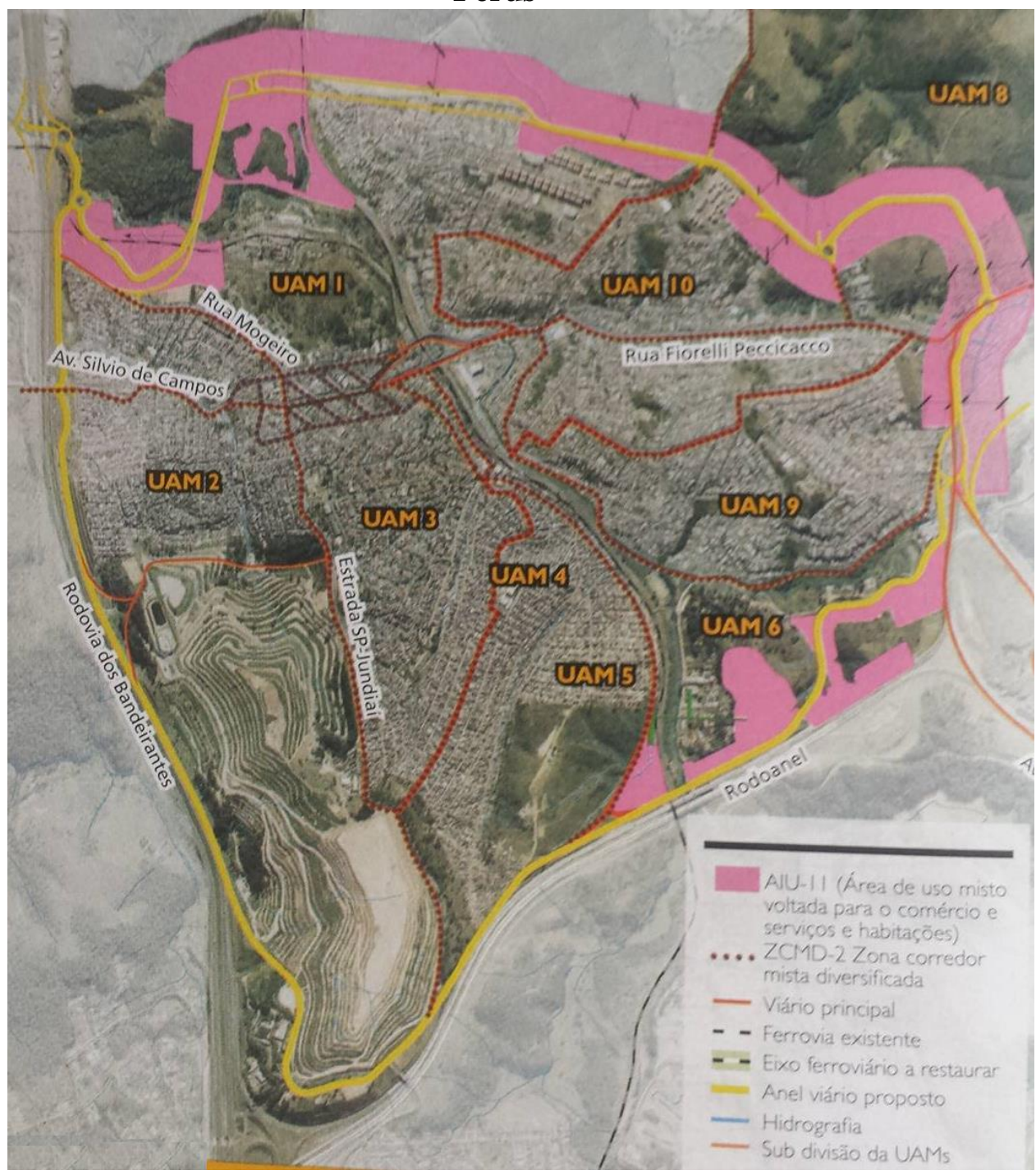

Fonte: (Salgado et al., 2012, p. 36)

${ }^{241}$ Um dos grandes terrenos vagos para o qual o Plano de Bairro previa loteamento e urbanização teve parte considerável de sua área ocupada desde 2015, como descrito no capítulo 1. 
Outra evidencia de que os objetivos da proposta do anel não são apenas viários, mas também imobiliários, é que em parte das propriedades lindeiras a esse anel o zoneamento seria alterado (após o fim das obras), permitindo maior aproveitamento da área do terreno e do potencial construtivo. Essa flexibilização do zoneamento seria dada pela Intervenção Urbanística 11, cuja área pode ser observada na figura 14, através da cor rosa.

Segundo os autores, essa mudança se justificaria, pois, os proprietários fundiários terão que ceder parte do terreno para a construção do anel viário. Se trataria, portanto, de uma contrapartida. O PL 0331/2011 trata o financiamento dessa obra de maneira evasiva, ao apontar duas formas distintas de parcerias público privadas como meios possíveis para seu financiamento. É notável que essa seja a única obra de todo este PL em que há uma preocupação com a engenharia financeira necessária para a sua realização - para todas as outras esse fato é negligenciado, deixando-se entender que o dinheiro deveria vir do fundo público. Essa atenção específica com o financiamento do anel viário de Perus é um indicativo de que essa é uma das obras mais prioritárias de todo o Plano ${ }^{242}$.

Uma das propostas possíveis, apresentadas para o financiamento, seria a parceria com os proprietários dos terrenos por onde o anel passaria. Esses teriam que passar parte da valorização imobiliária gerada pela edificação desse anel para a PMSP, que assim recuperaria o dinheiro gasto, de seus próprios fundos, para financiar a construção; a outra forma sugerida no PL 0331/2011, sem muitos detalhes, seria realizar a obra nos moldes de uma Operação Urbana Consorciada (OUC) ${ }^{243}$. Como nesse documento não há maiores informações, é possível especular que, caso fosse optada a segunda forma de financiamento, seriam colocadas à venda no mercado financeiro CEPAC ${ }^{244}$ para custear essa obra. Portanto, a construção do anel viário seria viabilizada por um sistema de contrapartidas associado a mais um nível de capital fictício atrelado à terra urbana de Perus - seja ele a mudança no zoneamento ou a venda de CEPAC na bolsa de valores.

\footnotetext{
242 No texto do PL 0331/2011 a implantação do Anel Viário de Perus é classificada como

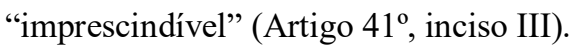

${ }^{243}$ Informações disponíveis no PL 0331/2011, artigo $8^{\circ}$, parágrafo $1^{\circ}$, incisos II e III.

${ }^{244}$ Certificado de Potencial Adicional de Construção (CEPAC) são títulos mobiliários, emitidos pela PMSP, utilizados como meio de pagamento de Contrapartida para a outorga de Direito Urbanístico Adicional dentro do perímetro de uma OUC. Cada CEPAC equivale a determinado valor de $\mathrm{m}^{2}$ para utilização em área adicional de construção ou em modificação de usos e parâmetros de um terreno ou projeto. Os CEPAC são negociados pela PMSP na Bolsa de Valores e, após a primeira venda podem ser revendidos livremente como um título mobiliário qualquer, até que sejam vinculados a um lote dentro do perímetro da Operação Urbana.
} 
Logo, como já exposto anteriormente, o Plano de Bairro, que se caracteriza por ser uma forma de capital fictício, contém em si outros mecanismos de intensificação da ficcionalização do capital.

Em seus escritos, o Plano de Bairro destaca o trecho norte do anel como prioritário. Muito provavelmente essa prioridade ocorre, pois essa área tem um acesso rodoviário limitado e contem dois grandes terrenos vazios, para os quais são previstos projetos de expansão urbana.

O traçado do desenho do anel viário de Perus faz algumas curvas abruptas que acabam deformando o anel, associadas a algumas rotatórias no meio de áreas desabitadas. Provavelmente, essas curvas foram pensadas para satisfazer necessidades futuras dos produtores imobiliários interessados nesses terrenos. Percebemos um enfoque especial do Plano de Bairro para o terreno que circunda a fábrica ${ }^{245}$. Essa área de expansão, segundo o próprio Plano de Bairro se refere a glebas pertencentes a Cia. Melhoramentos e a Família Abdalla. Nesse trecho, o anel desvia do terreno da Cia. Melhoramentos ${ }^{246}$ e passa, de maneira tortuosa, pela área da família Abdalla até chegar à Rodovia dos Bandeirantes.

A situação geográfica de Perus em relação aos meios de transporte (rodovias, ferrovia) e aos terrenos vagos leva os planejadores do espaço a elucubrarem sobre a chamada "vocação logística" do bairro de Perus, há alguns anos. Evidentemente, que esse também é um dos enfoques do Plano de Bairro de Perus.

A ideia de "vocação logística" de Perus é insistentemente colocada ao longo desse instrumento urbanístico ${ }^{247}$. O Plano de Bairro se autoproclama um meio de desencadear o desenvolvimento econômico do bairro através de uma ação principal: a construção de um centro logístico na UAM 6. A essa edificação estaria associada a um polo econômico que conteria: a construção de uma nova estação ferroviária, a modernização da ferrovia e a criação de um centro de apoio de comércio e serviços. Se caracterizaria, assim, uma nova centralidade econômica em Perus, localizada em um dos terrenos vagos na parte sul do distrito, mais especificamente, no entroncamento entre a Rodovia dos Bandeirantes com o Rodoanel, tendo como limite, a leste, a Avenida Raimundo Pereira de Magalhães (Figura 10).

\footnotetext{
${ }^{245}$ Como será abordado no próximo subtítulo.

${ }^{246} \mathrm{Na}$ época era propriedade da Cia. Melhoramentos, hoje, vendido e projetado para ser o Nesp.

${ }^{247}$ Novamente, ressaltamos a ideia de "vocação" - nesse caso logística - como uma reificação associada à publicidade promovida pelos instrumentos de planejamento para convencer os capitais financeiros de que é possível captar uma renda fundiária extraordinária com investimentos logísticos em Perus, tendo o Estado mostrado disposição a colaborar para que isso ocorra.
} 
Para essa realização se tornar-se viável, o Plano de Bairro propõe uma mudança de zoneamento para esse terreno vago. Na época da elaboração do PL 0331/2011 - sob a vigência da antiga "Lei de Zoneamento" - essa área era predominantemente destinada para ZEIS e, segundo o Plano de Bairro, deveria se transformar em uma ZCP (Zona de Centralidade Polar). No PL há a sugestão de que essa ZEIS fosse deslocada para outra parte do bairro, sem explicitar exatamente qual.

De fato houve uma mudança da nomenclatura dessa área na revisão do zoneamento em 2016. Com a nova LPUOS (Lei 16.402/16), a área do referido terreno vago se transformou em uma Zona Predominantemente Industrial (ZPI-1), cuja ocupação prevista deve ser a "implantação e manutenção de usos não residenciais diversificados, em especial usos industriais"248 (Lei 16.402/16). Confirmou-se, portanto, em 2016, o previsto pelo Plano de Bairro em 2008 (mesmo esse não tendo sido aprovado): a retirada de parte da área de ZEIS desse terreno e entrada de um zoneamento compatível com um novo polo logístico, ou outra atividade industrial ${ }^{249}$.

Essa mudança pode nos indicar que o potencial de extração de renda desse terreno vem aumentando nos últimos anos - especialmente pelas obras do Rodoanel Norte - e que o zoneamento que limitava seu uso para habitação social era um limitador dessa renda potencial. Uma alteração de zoneamento como essa - de ZEIS para ZPI-1 traz possibilidade de o proprietário ter uma renda fundiária mais elevada, visto que a promessa de trabalho futuro em sua propriedade aumenta consideravelmente, de modo que, além de poder elevar o preço de mercado de seu terreno no presente, ele também pode empenhar um capital fictício maior, visto que, teoricamente, há maior possibilidade de produção de valor em sua propriedade no futuro.

Observando esse terreno atualmente podemos notar que ele não se tornou um centro logístico como previsto no Plano de Bairro. Continua vazio, apesar da sua excelente localização, o que sugere a realização da prática especulativa imobiliária, enquanto seus proprietários aguardam o momento mais oportuno da extração de renda fundiária, o que provavelmente, está relacionado à conclusão do Rodoanel Norte.

A promessa de que Perus abrigará centros logísticos reverbera há alguns anos. Essa promessa de desenvolvimento via atividade logística, por mais que teime a se

\footnotetext{
${ }^{248}$ Para a nomenclatura utilizada pela PMSP na Lei 16.402/16, a atividade logística é compreendida como um tipo de ocupação industrial.

${ }^{249}$ Curiosamente a área de ZEIS retirada daí foi transferida para o terreno do entorno da fábrica de cimento, o que pode ser um sintoma de que realmente se pretende realizar um condomínio residencial nesse terreno, vinculado ao programa Minha Casa Minha Vida.
} 
realizar, de fato interfere na dinâmica econômica e territorial do bairro. Se pensarmos através da concepção de Harvey (1990) de que o preço da terra está relacionado com o quanto de trabalho futuro ela pode render, podemos inferir que o Rodoanel (que, em si, já pode ser interpretado como uma forma de ser do capital fictício) funciona como uma promessa de trabalho, uma possibilidade de acesso a um capital fictício maior para os proprietários de terras lindeiras a ele. A essa estrutura viária se articula uma série de outras projeções de intervenções no espaço para o futuro, como: Plano de Bairro, Nesp, condomínios residenciais, Parque Linear etc. Desse modo, está colocada uma pesada carga de promessas de trabalho futuro a ser incorporado no solo urbano de Perus. O que se traduz em aumento dos preços imobiliários e de capitais fictícios atrelados à propriedade da terra.

Esse aumento de preços é ainda mais notável tendo-se em vista que, no fim do século XX, Perus era um dos bairros com preço de $\mathrm{m}^{2}$ mais barato de São Paulo. De lá pra cá, vem se valorizando - de forma pontual e vagarosa, mas perceptível - sob os estímulos dessas promessas de desenvolvimento, que teimam a se realizar. A expectativa, especialmente dos proprietários de terras, é que um grande projeto se materialize de fato na região e irrompa um vertiginoso processo de valorização imobiliária. A aposta da vez é o Nesp ${ }^{250}$.

\section{Os interesses em torno da Fábrica de Cimento e da memória do bairro}

"A quase tragédia desta época é que a lembrança, ou se fixa como memória em objetos produtos e coisas, ou desaparece" (SEABRA, 2003a, p. 112)

O tema desse subitem é muito caro ao bairro de Perus por conta do espaço em questão ser central na sua formação socioespacial e por ser um espaço em disputa. A análise das propostas do PL 0331/2011 sobre a antiga CBCPP será feita em duas partes: sobre o terreno do entorno da fábrica, e sobre o edifício em si e seu simbolismo para o bairro.

O Plano de Bairro se vangloria de - por estar em uma escala mais próxima - ser um meio para atender às demandas da população do bairro. É notável que nele existe uma tendência de fazer isso, especialmente para alguns proprietários de terras como é o caso da família Abdalla. Além de planejar um anel viário passando no meio dos terrenos

${ }^{250}$ É curioso notar que o terreno previsto para abrigar o Nesp não fez parte do recorte espacial delimitado pelo Plano de Bairro (por mais que esteja inserido no distrito de Perus). 
desses proprietários - um local que atualmente é isolado de acessos rodoviários -, existe ainda no PL 0331/2011, uma espécie de "plano urbanístico específico" para essas terras ao norte da fábrica, onde os proprietários pretendem fazer um grande condomínio como relatado no capítulo 1. No Plano de Bairro, diversos equipamentos urbanos básicos estão planejados para serem construídos associados a esse condomínio, prevendo suas futuras demandas. Além disso, o anel viário - pensado, aparentemente, para solucionar o problema do intenso tráfego de automóveis - passaria no "quintal" do novo condomínio e permitiria aos novos moradores se locomoverem sem ter que, necessariamente, passarem por dentro do bairro de Perus.

Desse modo, um plano urbanístico específico foi feito - com dinheiro público para essa propriedade, já levando em consideração o empreendimento imobiliário privado pretendido aí. Essa ação, associada ao novo anel viário e à mudança no zoneamento levariam, indubitavelmente, a uma grande valorização desse terreno. Caso o Plano de Bairro se realizasse, o Estado criaria ótimas condições para a realização do empreendimento imobiliário almejado.

O Plano de Bairro prevê todos os equipamentos públicos que devem ser construídos para atender as demandas desse futuro condomínio (Mapa 6): 14 escolas para todas as faixas etárias, um clube escola, duas UBS e duas AMA, além de um hospital e a transformação da Escola Estadual Gavião Peixoto ${ }^{251}$ em uma faculdade não ficando claro se seria uma faculdade pública ou privada. Resumidamente, se o projeto se realizasse, o Estado em associação com grandes proprietários de terras (e seus financiadores) criaria um novo bairro, induzindo assim o surgimento de outra nova centralidade. Além disso, na figura a seguir é possível notar a proximidade entre o parque linear do córrego das Laranjeiras (continuação do parque do Bamburral) proposto no PL 0331/2011 e a área do empreendimento imobiliário pretendido pela família Abdalla. Pode-se afirmar que a consumação desse parque também valorizaria o novo condomínio, que contaria com outro "belo" espaço verde ao redor.

${ }^{251}$ Considerada a maior Escola Estadual de São Paulo, com mais de $14.000 \mathrm{~m}^{2}$ de terreno, 8.500 de área construída e aproximadamente 4000 alunos, divididos em 3 turnos. 


\section{Mapa 6 - Proposta urbanística do Plano de Bairro de Perus para reprodução e expansão urbana nas áreas próximas à fábrica de cimento}

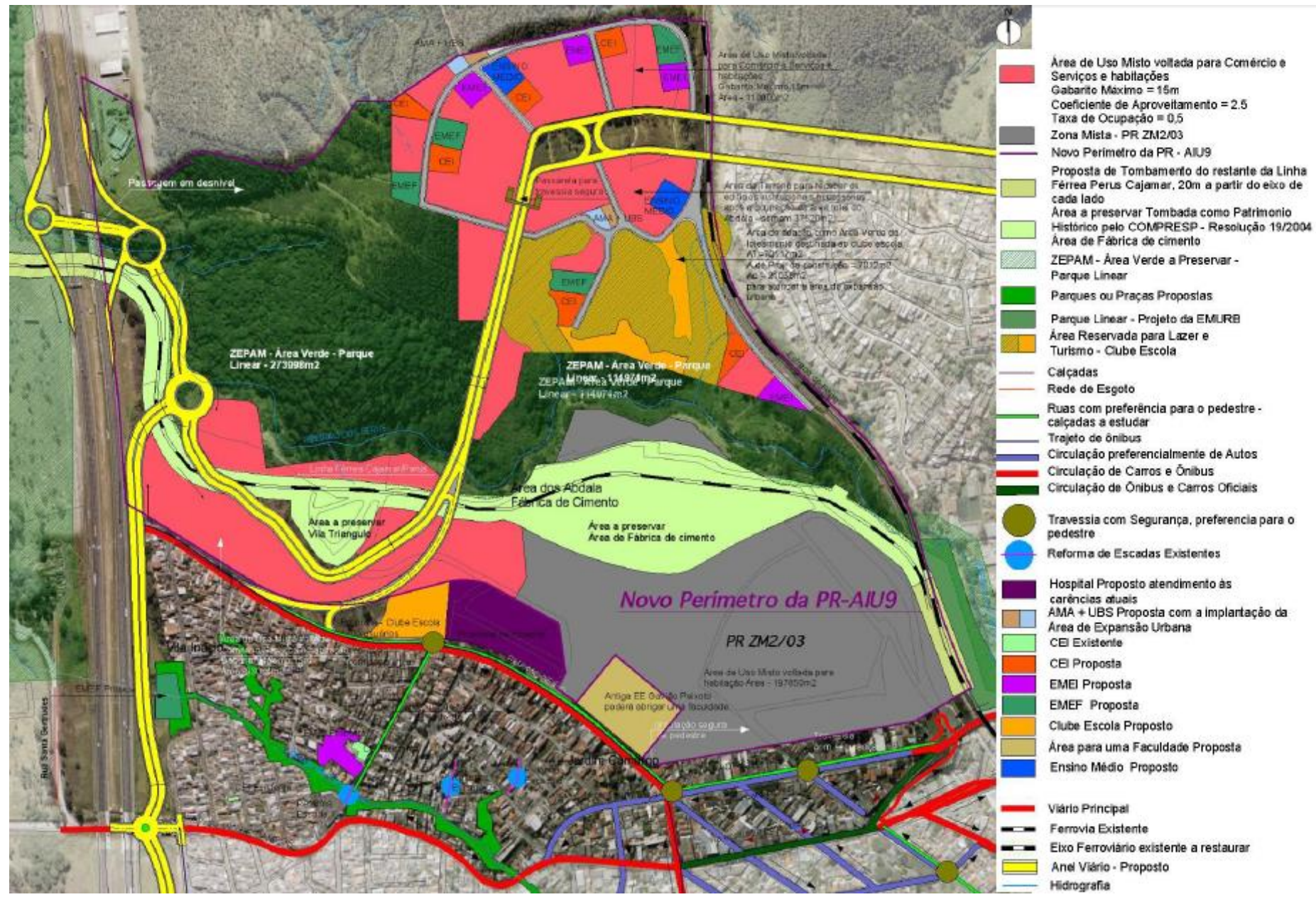

Fonte: Urbe Planejamento Urbanismo e Arquitetura (2008)

Destaque para as grandes áreas de expansão urbana em cinza e rosa, no entorno do prédio da antiga fábrica de cimento; e também para a proposta de parque linear na parte de baixo da imagem, em verde, na continuidade do córrego das Laranjeiras.

Há, portanto, nesse caso, uma consonância entre os interesses dos autores do Plano de Bairro e os proprietários do terreno do entorno da fábrica. Tanto isso é notável que durante a $32^{\mathrm{a}}$ reunião plenária do Confema (2008), que debatia o Plano de Bairro, os autores desse projeto relataram que estão sendo planejados dois novos bairros em Perus, próximos de Caieiras. Um dele seria no terreno da antiga Fábrica de Cimento, da família Abdalla, com um projeto que está sendo desenvolvido pelo arquiteto Ruy Othake, e outro projeto, de um grande proprietário, que também está desenvolvendo um plano de condomínio habitacional (Ibid. p. 18-9). Esse registro deixa explícito que há um diálogo entre os autores desses projetos (do Plano de Bairro e dos condomínios privados), o que demonstra um imiscuir entre o interesse privado e o interesse público. 
Segundo a proposta do Plano de Bairro, o prédio da fábrica de cimento não faria parte do condomínio residencial. A proposta do PL 0331/2011 para esta histórica construção é instalar um "Centro de Compras" (provavelmente um shopping center), associado a um "Centro Cultural de Luta pela Preservação Ambiental”. Sem dúvida, a efetivação dessas construções também significaria a valorização imobiliária do condomínio pretendido.

Através dessa proposta entra em cena uma disputa material e simbólica sobre a memória do bairro de Perus. Nesse momento o Plano de Bairro atua, a nosso ver, em uma tentativa de "apagamento" da memória operária e sindical e dos movimentos sociais atuais que reivindicam essa memória.

Em primeiro lugar, caso fossem aprovadas as construções propostas pelo Plano de Bairro para o prédio da fábrica haveria uma profunda descaracterização dos motivos que levaram esse a ter sido tombado, desvinculando-o, totalmente, de seu passado operário de militância "não violenta". Se aprovada a ideia de transformá-lo em um "Centro de Compras" e em um "Centro Cultural de Luta pela Preservação Ambiental", se configuraria, na prática, o “destombamento” do prédio - ação já buscada pela família Abdalla em outros momentos.

Do ponto de vista simbólico, a proposta do PL é um descaso com parte da população do bairro que, há mais de 30 anos, se organiza - através do sindicato e movimentos sociais - na luta pela desapropriação por interesse público dessa área. A proposta do "Movimento de Reapropriação da Fábrica de Cimento ${ }^{252}$ " para o edifício abandonado é transformá-lo em um "Centro de Lazer, Cultura e Memória do Trabalhador" associado a uma Universidade Livre e ao "Parque Luta dos Queixadas" (no terreno do entorno), tendo o intuito de preservar a memória sindicalista, formadora da identidade do bairro. Esse é um tema central de organização e militância em Perus nas últimas décadas e a proposta do PL 0331/2011, nos parece, uma resposta a esses setores organizados, mesmo não acatando a sua proposta.

A Fábrica de Cimento Portland (...), será reformada visando sua transformação em um Centro Cultural homenageando a memória cívica dos que lutaram contra a poluição por ela produzida em um movimento social ambiental pioneiro no Brasil, transformando-a em um marco do turismo ambiental combinadamente com um Centro de Compras abrigados em suas vastas instalações ${ }^{253}$.

\footnotetext{
${ }^{252}$ Coletivo que aglomera movimentos sociais, sindicato, ONG, CEB, entre outras organizações em prol da utilização do edifício da fábrica de cimento. Para mais informações ver: $<$ https://movimentofabricaperus.wordpress.com/>.

${ }^{253}$ PL 0331/2011, artigo $10^{\circ}$, inciso IX.
} 
A justificativa para um "Centro Cultural de Luta pela Preservação Ambiental" parte da seleção descontextualizada de um fato histórico, que é apropriado como um signo descolado de seu significado original. Esse fato é a luta contra a poluição que a fábrica emitia, associada à reivindicação do sindicato pela desapropriação do Sítio Santa-Fé para transformá-lo em parque. Resumir essa mobilização do bairro a "luta pela Preservação Ambiental" nos parece uma ação tática ideológica, com objetivo de disputar as representações sobre a formação socioespacial do bairro. A referida luta contra poluição - descrita no capítulo 1 - foi organizada através da paróquia do bairro, em associação com as lideranças sindicais e tinha como foco a conquista de melhores condições de vida e saúde para os moradores do bairro.

Evidentemente, a instalação de um centro de memória Queixada - como reivindica a militância de Perus -, que enfatize disputas entre capital e trabalho e que teria como uma figura de destaque negativo - o "mau patrão" - José João Abdalla, não é do interesse da família proprietária do terreno ${ }^{254}$. Essa proposta também não seria a mais interessante para os pretendidos negócios imobiliários no terreno do entorno.

Observada em seu contexto, a mobilização contra a poluição era uma forma de se aparecer a disputa entre capital e trabalho: os custos economizados pelo capital, com a não filtragem do pó de cimento, significavam um aumento das despesas para a manutenção da moradia e da saúde, por parte dos trabalhadores do bairro. No limite, a luta contra a poluição em Perus era um embate em torno da apropriação da mais valia produzida na fábrica de cimento: $O$ patrão poupava seu capital ao não instalar filtros adequados em suas chaminés, ao passo que, transferia esse custo para os trabalhadores, que tinham que empenhar maior parte do seu salário e do seu tempo livre para garantir suas condições de sobrevivência (prejudicada pelo pó da fábrica), caracterizando assim um aumento na exploração do trabalho.

A reivindicação de desapropriação do Sítio Santa-Fé, liderada pelo sindicato Queixada, era parte da disputa capital-trabalho, tanto no que diz respeito a luta por melhores condições de vida para os trabalhadores, quanto porque fazia parte das negociações sobre a dívida trabalhista da CBCPP contraídas a partir da greve de 1962.

A manobra ideológica contida no Plano de Bairro é eleger um aspecto específico da acirrada disputa entre capital e trabalho da história de Perus, descontextualizá-lo e enquadrá-lo como luta ambiental. Essa é uma ação, inclusive, anacrônica, pois, na

\footnotetext{
${ }^{254}$ Segundo depoimentos de militantes, nos quase 30 anos em que se luta pela reapropriação da fábrica,
} nunca os proprietários sinalizaram abrir qualquer negociação com a população local sobre esse tema. 
época, os princípios que, mormente, embasavam essa mobilização não eram os ecológicos ou ambientais, mas sim os cristãos e sindicais. Como descrito no capítulo 2 , a capacidade contestatória do atual ambientalismo dominante é diminuta, de modo que propor esse anacronismo e associar as lutas do bairro ao ambientalismo é tentativa simbólica de afastá-las de sua face mais radical, a fim esteriliza-las. O que se torna mais visível quando essa associação é feita como uma imposição de um projeto de planejamento, que assumidamente foi elaborado em diálogo com os proprietários da fábrica (Confema, 2008).

Sendo assim, segundo a hipótese aqui defendida, o Plano de Bairro coloca, sutil e estrategicamente, a luta pela preservação ambiental em oposição à luta operária, como um meio de desviar a organização em torno da luta dos trabalhadores. A tática do Plano de Bairro é eclipsar uma luta com outra luta. Ambiental sobre a sindical. Pensada a decomposição como uma ideologia em que a burguesia, através da tecnocracia “(...) organiza a banalização das descobertas subversivas e as difunde amplamente, depois de esteriliza-las" (JACQUES, 2003, p. 44), temos nesse caso um exemplo de como o discurso ambiental foi incorporado como ferramenta reprodutora das relações sociais de produção.

Aqui vale ressaltar, como já exposto anteriormente, que há um descompasso nas representações em torno da questão ambiental: entre a utopia e a ideologia. A disputa contra a poluição em Perus não se restringia a um caráter ecológico apenas, tratava-se de uma questão de saúde humana, especificamente da saúde da classe trabalhadora. Ou seja, não havia nesse es forço contra a poluição um entendimento da natureza como algo separado do humano, pelo contrário, o real motivo de se criar um enfrentamento contra a poluição do ar era um problema cotidiano presente na vida dos trabalhadores. Não se tratava de se lutar por uma "natureza intocada" ou pelas condições de vida de gerações futuras, sim pela saúde da população, no presente.

A proposição de se reutilizar o prédio da fábrica através de um "Centro de Compras" associado a um "Centro Cultural de Luta pela Preservação Ambiental" faz parte da tentativa de se associar um novo signo ao bairro de Perus, que por um lado se sobrepõe ao signo já posto - porém "ultrapassado" - de bairro operário e, por outro coloca esse bairro em conexão com uma das mais modernas agendas políticas internacionais, que é a luta pela preservação do meio ambiente. Fato que, para além do caráter ideológico, pode ser revertido em uma maior capacidade de os proprietários de terras extraírem maior renda, graças à condição exclusiva desse bairro na metrópole - 
como já exposto - relacionado às grandes áreas verdes do entorno. Para fazer valer essa renda de monopólio e, assim, propiciar lucrativos negócios imobiliários, se faz necessária a criação desse signo ambiental sobre Perus e, para a construção desse, há uma disputa sobre qual memória do bairro vai ficar para a história.

Sobre esse assunto Harvey fez interessantes formulações que nos podem ser úteis. Esse autor faz um desvio do conceito de capital simbólico de Bourdieu (1984) expandindo sua abrangência da propriedade de um indivíduo para a de todo um grupo. Surge assim a ideia de um capital simbólico coletivo (HARVEY, 2012). Para esse autor, práticas culturais historicamente construídas e características espaciais específicas podem conferir a um lugar uma autenticidade capaz de captar rendas de monopólio. Segundo o autor, o turismo que explora as especificidades de cada lugar para vendê-las é o exemplo mais obvio desse fato. Harvey afirma que atualmente, centros urbanos com menos capital simbólico reconhecido socialmente, tentam aumentar seu quociente desse capital para gerar uma singularidade que resulte em rendas de monopólio. Podemos, a partir dessa teoria, afirmar que está em processo em Perus uma tentativa de se criar um capital simbólico coletivo em torno da sustentabilidade. E que o Plano de Bairro, dentre outros objetivos, busca afirmar uma nova especificidade a esse bairro, não só pela logística, mas também pelo signo de preservação ambiental.

A renda de monopólio gerada pelo capital simbólico coletivo se faz em um movimento conjunto de valorização de aspectos históricos locais e realização de novas obras. Com a expansão da indústria do turismo essa prática tem se espalhado por diversas cidades do mundo. Exemplo emblemático é a cidade Barcelona que, nos anos 1990, sofreu uma reestruturação urbana calcada na seleção e valorização da memória cultural e arquitetônica catalã e, na reprodução do espaço urbano através de novas e modernas construções.

Entretanto, Harvey traz o pertinente questionamento: qual memória coletiva vira história? Ou seja, para que algum fato cultural seja associado à imagem de certo local, seguramente, outros tiveram que ser preteridos. E assim o foi também em Barcelona (Ibid.). Há, portanto, uma disputa - em diversas partes do globo - pela memória local, que, normalmente, acaba sendo vencida pelas classes hegemônicas. Guardadas as proporções, podemos também nos questionar se em Perus há uma disputa por qual 
memória vai vir a se tornar o capital simbólico coletivo do bairro: as lutas pela defesa do meio ambiente ou a memória sindicalista grevista radical ${ }^{255}$ ?

A partir desses apontamentos de Harvey podemos considerar que ocorre, em distintos níveis, a decomposição da história e cultura locais, tornando-as mercadoria (uma "coisa", reificada) que gera uma maior renda de monopólio. As históricas "lutas de defesa do meio ambiente" de Perus (que em verdade são lutas por uma melhoria na vida cotidiana dos trabalhadores) foram tornadas argumentos de um signo - ou nos termos de Harvey, um capital simbólico coletivo - que se quer impor ao bairro. Dessa forma, é notável que há um movimento de mercantilização de tudo que é possível: não só do ar, mas também das paisagens e das mobilizações sociais históricas do bairro. A espetacularização da memória contra poluição - isto é, seu descolamento da realidade dos fatos - é colocada como ponta de lança dos projetos imobiliários que, no limite, vão se voltar contra as populações que são as herdeiras diretas das lutas contra o pó de cimento ou da luta contra a poluição do lixão. Verificado um aumento dos preços imobiliários, a população mais pobre terá que se deslocar do bairro.

Dentro de sua teoria, Harvey sugere uma possibilidade de resistência por parte da população local frente às investidas dos capitais fluidos que buscam um significativo capital simbólico coletivo como meio de ganho ganhos fundiários. A proposta desse autor é que os movimentos sociais locais têm que se organizar para se apropriar do capital simbólico coletivo (e não o contrário), de modo que os atores sociais hegemônicos não sejam os únicos que se apropriam das rendas de monopólio geradas a partir de uma espetacularização da cultura local. Harvey se refere à possibilidade de criação de "espaços de esperança" que permitam a reflexão e prática anticapitalista (2012, p. 201), associados a esse movimento de apropriação da renda pela população local.

$\mathrm{Na}$ esteira do que diz o autor, podemos identificar o "Movimento de Reapropriação da Fábrica de Cimento" como uma organização que busca consolidar um tipo de espaço de esperança. Suas principais reivindicações são:

1. Instalação do Centro de Lazer, Cultura e Memória do Trabalhador, segundo aspiração já antiga do Movimento Queixada. 2. Instalação de uma Universidade Livre e Colaborativa articulada ao Centro do Trabalhador. 3.

\footnotetext{
${ }^{255}$ Em 1990 foi descoberta a "vala de Perus", localizada no cemitério Dom Bosco. Uma espécie de cemitério ilegal onde foram encontradas 1.049 ossadas de indigentes, presos políticos e vítimas dos esquadrões da morte do período da ditadura militar brasileira. Disponível em: < http://www.desaparecidospoliticos.org.br > Acessado em: 11 de setembro de 2018. Podemos nos questionar por que a memória da "vala de Perus" não vem à tona, no Plano de Bairro, como algo marcante no bairro. Em nenhum momento esse importante fato histórico é citado.
} 
Instalação de núcleos de pesquisa e outras instituições públicas voltadas à construção do conhecimento, cooperação e à formação ${ }^{256}$.

É notável que, no cerne desse movimento, está o objetivo de instalar espaços privilegiados para a reflexão e desenvolvimento do conhecimento. Também se nota um posicionamento claro na disputa pela memória do bairro. Posição que destoa da proposição exposta no Plano de Bairro.

Recentemente, em 2018, a Comunidade Cultural Quilombaque - integrante do "Movimento de Reapropriação da Fábrica de Cimento" - lançou a "Queixadas Agência de Desenvolvimento Eco Cultural Turístico", como uma proposta de geração de renda para a população local a partir das singularidades da região ${ }^{257}$. Há um ponto de contato entre a proposta dessa agência e a teoria que Harvey (2012) propõe sobre os movimentos locais se apropriem das rendas geradas pelo capital simbólico coletivo. Não é objetivo dessa dissertação analisar essa ação da Quilombaque em específico. Nossa intenção ao apresenta-la é demonstrar que o processo de reestruturação imobiliária em curso sugere a possibilidade de extração de renda fundiária para distintos atores sociais e que esse movimento social se colocou nessa disputa de apropriação da renda, propondo outra expressão capital simbólico coletivo - distinta da expressão dominante, proposta pelo Plano de Bairro e outros projetos de planejamento ${ }^{258}$.

Após a extensa análise desse documento, podemos resumir que, apesar do Plano Bairro ter sido bancado pelo dinheiro público, suas propostas estão em consonância com os interesses dos grandes proprietários de terra do bairro e são um "convite" aos investidores imobiliários, que podem se valer de um detalhado diagnostico socioespacial e de um plano para expansão de negócios urbanos, que contém em si soluções urbanísticas para modernização das infraestruturas urbanas e a flexibilização do zoneamento. Novamente, observamos que os tecnocratas do espaço "confundem" bem público com crescimento econômico (via desenvolvimento de negócios

\footnotetext{
${ }^{256}$ Retirado de <https://movimentofabricaperus.wordpress.com/sobre-o-movimento/principaisreivindicacoes/>. Acesso em 15/11/2016.

257 A agência propõe que turistas possam conhecer a região através de "trilhas de aprendizagens" que passariam por locais como: a vala clandestina do cemitério Dom Bosco; o acampamento irmã Alberta do MST; as antigas cavas de ouro próximas ao Jaraguá; a estrada de ferro Perus-Pirapora; a fábrica de cimento, entre outros espaços. O PDE (2014) delimitou o "Território de Interesse da Cultura e da Paisagem" (TICP) Jaraguá/Perus, que demarca um Complexo Eco/Turístico/Ambiental, cujo perímetro é hoje formado pela Fábrica de Cimento Perus, pelo Centro Temático da Estrada de Ferro Perus-Pirapora, pelo Parque Anhanguera e pelo território indígena Guarani, no Jaraguá, fato que foi considerado uma vitória pelos movimentos sociais de Perus. Trata-se de uma nova diretriz do planejamento, cujos desdobramentos ainda não aparecem com clareza.

${ }^{258} \mathrm{Na}$ mesma esteira, ocupações de imóveis vazios têm sido, nessa disputa simbólica e imobiliária, uma forma de lutar pela afirmação da cultura periférica. A "Casa de Hip Hop" e a "Ocupação Artística Canhoba" são exemplos bem sucedidos desse tipo de ação política cultural.
} 
imobiliários), de modo que apresentam um Plano de Bairro que é um projeto de aceleração do processo de reestruturação imobiliária em Perus.

No que tange às características "sustentáveis", o PL 0331/2011 reitera, e torna ainda mais evidente, o exposto sobre o tema através dos dois projetos analisados nos itens anteriores: o "verde" espetacularizado, utilizado como diferencial capaz de oferecer rendas fundiárias extraordinárias e as intervenções "ambientalistas", via parques lineares, que fazem parte de um projeto de higienização social associado à reestruturação imobiliária. Essa última constatação terá análise desdobrada no capítulo a seguir. 


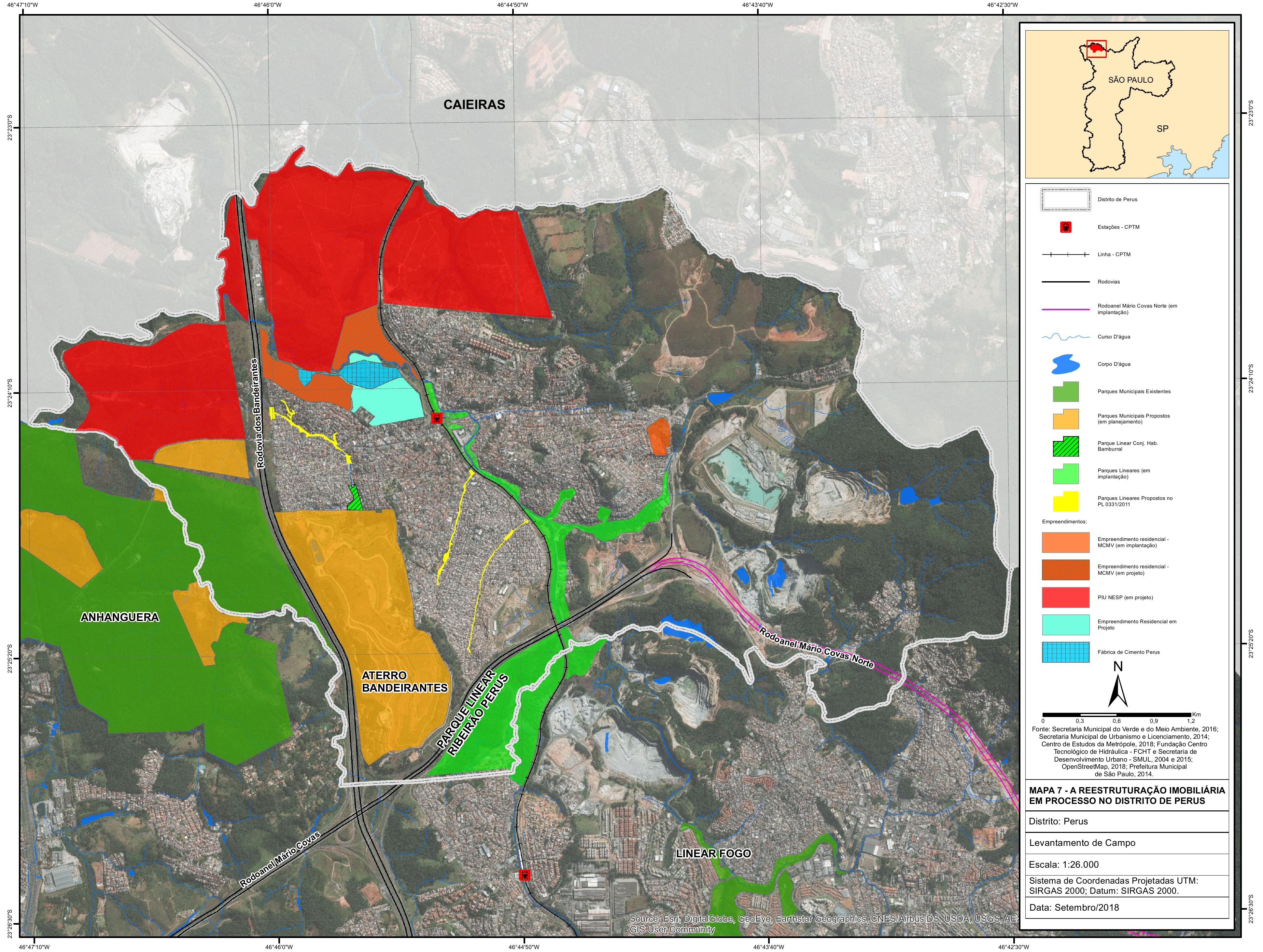




\section{DA CIDADE SAUDÁVEL À CIDADE "SUSTENTÁVEL": HIGIENISMO, SANITARISMO E AMBIENTALISMO}

No capítulo anterior, analisamos o surgimento da modalidade de urbanismo “sustentável" especificamente nos projetos voltados à região de Perus. Procuraremos agora examiná-lo enquanto uma política pública que cumpre papel de inserir espaços nos circuitos de valorização do capital. Não se trata de uma política espacial tão nova assim, isso porque é possível notar semelhanças e continuidades entre esse ambientalismo e a prática derivada da filosofia higienista. Ao longo deste capítulo final, buscaremos demonstrar alguns parâmetros de comparação entre essas duas filosofias e suas ações.

\subsection{O Higienismo: domesticação do espaço e da classe trabalhadora}

Em "Higienismo e ambientalismo: filosofias do urbano", Seabra (2013) disserta sobre algumas características que permitem observar certo "fio de continuidade" entre higienismo e ambientalismo. Tomás (1996) também aponta para a importância de se atentar à perenidade entre essas duas filosofias: “(...) nos convencemos de que o higienismo é um instrumento básico para a compreensão da problemática ambiental. Sem retomá-lo, sem resgatá-lo, fica incompleta qualquer discussão sobre o assunto." (TOMÁS, 1996, p. 8).

Nosso intuito nesse capítulo é, a partir dos projetos estudados nos capítulos anteriores, estabelecer uma leitura sobre essa hipótese de continuidade. Dada a amplitude de ações que reverberam dessas duas filosofias, optaremos por centrar a análise mais especificamente sobre como ambas pensam e atuam em relação às áreas de rios e planícies de inundação dos espaços urbanos. Para tanto, necessitamos compreender brevemente o contexto de surgimento da filosofia higienista para, então, estabelecermos nexos entre esse passado e as políticas que são objeto dessa pesquisa. Portanto, abordaremos as origens das ideias e das práticas higienistas em geral, sem um enfoque sobre uma cidade específica. No momento seguinte dirigiremos o foco sobre o desenvolvimento do higienismo na cidade de São Paulo.

A partir do século XVIII - em um contexto de acumulação primitiva e revolução industrial - a doutrina higienista passou a se estabelecer como norma e como prática de 
adequação de espaços e de pessoas. As cidades passaram a ter novos conteúdos sociais, impostos pelo sentido produtivo do capital.

A cidade pré-industrial não dispunha de formas adequadas para comportar a crescente produção industrial. Por mais que seu espaço representasse uma aglomeração - fenômeno importante para a grande indústria - foram necessárias reestruturações espaciais na "velha" cidade que assegurassem o crescimento do capital industrial.

As massas de trabalhadores "livres" 259 ", atirados do campo para a cidade, se estabeleciam, normalmente, nos piores locais dos sítios urbanos e em condições de moradia muito ruins. Analisando esse período na Inglaterra, Engels (2010) demonstra que a legião recém-surgida de pobres urbanos, passou a fixar suas moradias em áreas de planícies de inundação, canais fluviais e de esgoto, porões úmidos, cortiços, alagados, entre outros espaços em péssimas circunstancias.

É central destacarmos que, desde que o fenômeno urbano-industrial ganhou acento, a partir do final do século XVIII, as áreas de rios e várzeas passaram a ser resignificadas dentro das cidades. Esses espaços, cujos tipos de uso eram específicos e condicionados pela sazonalidade das enchentes, passaram a ser utilizados de forma sistemática e ininterrupta. Tornaram-se uso comum (e dramático) servir de moradia para a classe proletária que enfrentou (e ainda enfrenta) a dinâmica fluvial sazonal através de técnicas construtivas rudimentares, não industriais. Outra nova característica dos corpos d'água urbanos pós-revolução industrial, era a de ser receptáculo de esgoto, massivamente produzido pelas indústrias e pela população concentrada espacialmente.

Engels, observando as cidades industriais inglesas, da primeira metade do século XIX, assim descrevia tal fenômeno: "uma recente inspeção (na cidade Nottingham) revelou que várias filas de casas estavam construídas sobre canais de esgotos pouco profundos, cobertos apenas pelas tabuas dos assoalhos. Idêntico panorama nos oferecem Leicester, Derby e Shefild" (ENGELS, 2010, p. 80).

O processo de modernização industrial tornou o "velho" espaço urbano insalubre, concentrando espacialmente a poluição e a pobreza humana. A massiva migração campo-cidade levou ao surgimento de uma relativa raridade de espaço, o que gerou a ocupação de locais não antes habitados. Situação definida, sobretudo, pela relação bastante desigual entre os baixos rendimentos dos proletários e o alto preço da mercadoria habitação urbana. A cidade industrial foi ganhando forma, tendo como

${ }^{259}$ Ou seja, não eram servos ou escravos. No entanto, tendo como única fonte de subsistência a venda da própria força de trabalho, estavam totalmente subjugados às necessidades do capital. 
elemento estruturador a segregação socioespacial, produto da relação dialética entre as classes sociais urbanas, caracterizada por um movimento de proximidade e distanciamento espacial.

Nesse contexto histórico, dois fatores decisivos influenciaram as circunstâncias sanitárias ruins da cidade. O primeiro é que, com o surgimento da grande indústria, os proprietários de terras urbanas tiveram a possibilidade de extrair rendas de qualquer pedaço de terreno urbano, inclusive os mais inóspitos. O segundo, diretamente relacionado ao anterior, é que o proletário - "atraído" para a cidade pela grande indústria e transformado em "coisa" - foi obrigado a se sujeitar a morar em lugares onde ninguém habitaria:

(...) onde havia uma passagem supérflua, ela foi substituída por uma edificação; o valor da terra tornou-se mais alto com o desenvolvimento industrial e quanto mais subia, mais freneticamente se construía, sem a menor preocupação com a saúde e conforto dos moradores, com o único objetivo de obter o maior lucro possível e com base no principio de que, por pior que seja um casebre, há sempre um pobre que não pode pagar por outro menos ruim (ENGELS, 96, 2010, grifos do autor).

Mesmo significando uma possibilidade de ganho para a classe dos proprietários fundiários, essa situação evidencia-se como uma contradição no processo modernização industrial no instante em que essas precárias condições de reprodução da força de trabalho convertia-se em surtos de doenças, atrapalhando o fluxo de mercadorias (inclusive da própria mercadoria força de trabalho) e colocando em risco as próprias classes dominantes, pois as epidemias (de tuberculose, de cólera, de tifo etc.) não se restringiam ao proletariado. Isto é, a busca de lucro incessante colocava sob ameaça a reprodução do próprio sistema capitalista.

É nesse contexto - de contradições na gênese da cidade industrial - que ganham corpo as ideias do higienismo, que segundo Seabra (2013) devem ser compreendidas como uma filosofia do urbano, ou seja, uma concepção do que deveria ser o espaço urbano $^{260}$. A partir dessa concepção buscamos regular as contradições supracitadas, através de ações levadas a cabo pelo Estado.

Duas necessidades materiais do capital justificaram o desenvolvimento da filosofia e prática higienista. A primeira: diciplinar as práticas socioespaciais dos camponeses tornados, abruptamente, proletários. A segunda: expandir espacialmente a mancha urbana que dava suporte à produção capitalista.

\footnotetext{
${ }^{260}$ No capítulo 2, destacamos que também o ambientalismo pode ser assim interpretado.
} 
O ideário que sustentou o enfrentamento dessas necessidades tem raízes na Teoria dos Meios, desenvolvida na Grécia Antiga, por Hipócrates. Formulada nos séculos IV e V a.C., essa teoria estabeleceu uma relação de determinação entre as características do meio físico e as condições de saúde. O conhecimento dessa relação deveria orientar os costumes dos habitantes de cada localidade. Conhecer a dinâmica das águas, relevo, ventos, estações, enfim, do meio ambiente local seria uma forma de identificar e se adequar às possíveis epidemias (ANDRADE, 1996).

A partir daí o arquiteto Vitrúvio, passou a escrever sobre preceitos para a construção de cidades no Império Romano, com a ideia básica da conjugação entre conhecimentos de arquitetura e de medicina (TOMÁS, 1996). Cabanis, já na virada do século XVIII para o XIX, aprofundou outra linha da Teoria dos Meios, de grande influencia sobre parte do pensamento higienista: a ideia de que há uma associação direta entre os efeitos do meio e a moralidade humana. Trata-se de um determinismo espacial sobre a moral dos sujeitos: "um bom ambiente forma bons cidadãos, enquanto um mau meio ambiente forma maus cidadãos" (CABANIS, s/d, apud ANDRADE, 1992, p. 21). Se conforma, portanto, um influente aspecto na filosofia higienista, segundo o qual as pessoas que vivem em espaços com condições "degradadas" formam uma "moral degradada", e vice versa.

Aqui, precisamos fazer um parêntesis: esse embasamento determinista deu origem ao lado mais explicitamente nefasto do higienismo, capaz de "justificar" ações truculentas, discriminatórias e moralistas. É desse ramo teórico do higienismo que se desdobra o movimento pseudo-científico eugênico, que acreditava que características morais e intelectuais eram transmitidas geneticamente, e considerava que higienizar a sociedade era exercer um controle populacional mais incisivo, em prol da dominância da raça humana superior, a branca ${ }^{261}$. Apesar de, aparentemente serem coisas distintas, em diversas situações históricas é difícil diferenciar o que é higienismo e o que é eugenia.

Outro contributo importante para o higienismo foi a Teoria dos Fluidos, elaborada nos séculos XVIII e XIX. Sua concepção está centrada na ideia de que a imobilidade (a estagnação) da água e do ar seriam condições básicas para o surgimento de epidemias. Em oposição, a ideia de circulação (movimento) seria algo benéfico para

\footnotetext{
${ }^{261}$ A prática de controle sobre os corpos pregada pelos movimentos eugênicos tinha como alvo especial os mais pobres, as mulheres, os negros, os mestiços, as prostitutas, os homossexuais e os portadores de deficiências físicas ou mentais entre outros (MISKOLCI, 2005).
} 
a saúde social. Essa teoria médica se amparava na Teoria Miasmática, que acreditava que as doenças estavam literalmente nos lugares e que se propagavam por meio de odores $^{262}$.

Do ponto de vista das ideias, essas são as principais matrizes da filosofia higienista. Essa se traduziu em duas ciências instrumentais principais: a medicina social (e política) e a engenharia sanitarista ${ }^{263}$.

Quando o princípio de aglomeração, inicialmente benéfico para a indústria, passou a operar de forma negativa - com acúmulo demasiado de resíduos e população não produtiva -, os preceitos higienistas apareceram como um meio de combater a parte inconveniente da aglomeração. Sua resposta era científica: impondo a fluidez e a circulação da água, do ar e das mercadorias, determinando quais costumes eram aceitáveis para os seres humanos em determinados espaços, atualizando as estruturas espaciais da "velha" cidade e disciplinando os camponeses a ter hábitos urbanos "saudáveis".

O higienismo, veículo dessa transformação, "tratou de produzir estruturas materiais que eram suportes para os fluxos necessários à produção tanto de trabalho como de capital" (SEABRA, 2013, p.3). Foi, portanto, um ideário protagonista de uma nova rodada de modernização, que ocorreu fora do espaço da fábrica. Tratava-se de domesticar o espaço e os hábitos dos seres humanos. O disciplinamento do comportamento do trabalhador passou a não se restringir apenas ao tempo em que estava trabalhando, e chegou até a sua casa, determinando como se deveria morar, se comportar em público e no âmbito familiar. A produção industrial também saiu da fábrica e passou a se realizar no âmbito da cidade, através de construções urbanas higiênicas.

Nesse período, médicos e engenheiros passam a ganhar espaço em cargos políticos, e reuniões internacionais sobre higienismo começam a ser mais comuns,

\footnotetext{
${ }^{262}$ A teoria dos miasmas foi superada pela teoria bacteriológica, que começou a ser comprovada no fim do século XIX. No entanto, sua aceitação completa entre os médicos não ocorreu imediatamente, de modo que se continuou crendo nos miasmas durante décadas do século XX. Para mais informações sobre a gênese histórica do higienismo ver Tomás (1996) e Andrade (1996).

${ }^{263}$ A filosofia higienista se desdobra no sanitarismo. Enquanto o higienismo exerce o controle social através da medicina (social e política), o sanitarismo trabalha no mesmo sentido através da realização de obras de engenharia sanitarista. As questões higiênica e sanitária formam um par de atuação conjunta, sendo os preceitos da primeira básicos para a prática da segunda. "A medicina terminaria por determinar o 'por que' fazer, enquanto a engenharia ficaria responsável pelo "como"” (TOMÁS, 1996, p. 17). Dada essa complementaridade entre higienismo e sanitarismo, daqui em diante não realizaremos mais distinções importantes entre as duas práticas. Assim, quando usarmos qualquer um dos dois termos estaremos nos referindo ao conjunto higienismo / sanitarismo.
} 
culminando em uma projeção do higienismo em escala mundial, o que se materializou em normatizações sanitaristas e reformas urbanas por toda Europa e, posteriormente por outros continentes - difusão ocorrida ao longo do século XIX e início do XX. Diversos centros urbanos ao redor do mundo viveram a busca por "cidade saudável”, máxima utilizada pelo discurso higienista e ideia importante para forjar uma organização socioespacial que respaldasse as necessidades da reprodução ampliada de capital: "As urgências de uma época justificaram o higienismo como prática que tinha a ver com domesticação do espaço, do tempo e da vida, em função das necessidades postas pelo desenvolvimento capitalista das sociedades modernas" (SEABRA, 2013, p. 4).

Tendo como base a teoria dos fluidos e, sob a bandeira da saúde pública, realizaram-se intervenções da engenharia sanitarista em espaços insalubres da cidade, destruíram-se estruturas antigas, que foram substituídas por construções em padrão higiênico e extensas as áreas de circulação ${ }^{264}$. A noção de que as doenças estavam nos lugares fez com que áreas de corpos d'água de diferentes naturezas (pântanos, estuários, remansos, várzeas, lagoas etc.) fossem associadas a miasmas e, portanto, alvos preferenciais das obras sanitaristas. Como é sabido, as intervenções pautadas pelas ideias higienistas não conseguiram dar fim aos problemas sanitários relacionados à pobreza extrema ou à destinação de resíduos, assim como alguns hábitos proibidos não acabaram com a restrição dada pela normatização, esses fenômenos foram momentaneamente separados da "cidade saudável”, afastados por um cordão sanitário.

É sabido que as reformas urbanas foram movidas por outros propósitos diferentes do ideal higienista, mas que confluíam com sua prática. É central identificarmos os interesses imobiliários envolvidos na domesticação do espaço. Drenar pântanos, fazer pontes, preparar o espaço para adquirir uma forma intercambiável no mercado foi um dos produtos do higienismo. Ações capazes de fragmentar o território e criar novas propriedades fundiárias, com importante valor de uso nas cidades. $\mathrm{O}$ desenvolvimento das forças produtivas significou a ampliação da habitabilidade de áreas do planeta, não sem contradições. Além de inserir novas terras no mercado, as obras sanitaristas ainda cumpriam um importante papel de valorização do espaço, dado pela transformação de um espaço "degradado" em um local com "capital fixo fixado no território" (SEABRA, 2013, p. 20). Muitas vezes essa força produtiva acoplada ao

\footnotetext{
${ }^{264}$ É importante ressaltar que o que se conhece hoje como "urbanismo", essa ciência parcelar aplicada, originou-se a partir da engenharia sanitária, que se desdobrou em urbanismo sanitarista.
} 
território, também era acompanhada de uma obra de "embelezamento", o que trazia um outro componente de incremento à renda fundiária.

Observar as diferenças de renda fundiária internas ao espaço urbano nos ajuda a compreender o fato de ser economicamente mais rentável investir no "melhoramento" de áreas inóspitas à produção (“degradadas”), mas com boa localização em relação à centralidade, do que investir na extenção espacial da cidade, em busca dos sítios mais adequados. Isto é, na lógica do capital é mais vantajoso, por exemplo, (buscar) anular o caráter sazonal das enchentes de fundo de vale de um rio em área central, do que ocupar um terreno de interflúvio mais afastado da centralidade. Ainda pensando nesse exemplo abstrato, em muitos casos, são os trabalhadores os ocupam essas áreas inósptas inicialmente, a partir de técnicas construtivas rudimentares. Posteriormente ocorre uma intervenção higienista, baseada em técnicas industriais incorporando capital fixo ao solo, aumentando o potencial das propriedades do entorno para captação de mais-valia, através da renda.

É possível observar que o setor de construção teve seus primeiros momentos de organização sob um regime industrial de fabricação, fato já consumado anteriormente em outros segmentos produtivos. É verdade que isso ocorre de forma decisiva a partir de investimentos a fundo perdido do Estado, no entanto, é notável a presença de capitais financeiros investidos no desenvolvimento imobiliário, como no caso da reforma urbana da cidade de Paris, orquestrada por Hausmann, no século XIX (HARVEY, 2015).

Além do imobiliário e da "saúde pública", outro interesse mobilizado através do higienismo foi o de vigilância e repressão da classe trabalhadora. O processo de proletarização, engendrado pela acumulação primitiva, foi indispensável para o desenvolvimento o industrial, mas contraditoriamente gerou uma ameaça à burguesia: a concentração espacial das classes dominadas, sob péssimas condições de vida, possibilitava momentos de irrupção social e/ou organização política. A Primavera dos Povos, em 1848, foi um alerta do potencial explosivo da reunião massiva de proletários nos centros urbanos. As medidas policiais sanitárias e as reformas urbanas foram uma resposta higienista a esse risco. O paradigma de vigilância panóptico, baseou tanto a construção de instituições de reclusão quanto a destruição de vielas, substituídas por bulevares. A aglomeração urbana passou a representar uma ameaça à ordem social 
burguesa não só pelas epidemias, mas sobretudo, pelo risco de tomada de consciência de classe e revolução ${ }^{265}$.

As diversas questões envolvendo as condições de vida da classe trabalhadora passaram a ser abordadas, pelo poder público, de uma forma estritamente técnica ${ }^{266}$. Em A situação da classe trabalhadora na Inglaterra, Engels descreve a vida nas cidades inglesas do início do século XIX e cita uma série de periódicos e relatórios públicos cuja linguagem para se referir à pobreza urbana era, praticamente, toda realizada em termos higienistas. A pobreza virou uma questão sanitária.

Ignoravam-se a origem social, econômica e política da pobreza e explicavam-na como uma questão moral, cultural ou até genética. A "cidade saudável” precisava de "bons cidadãos" e o saber médico era tido como aquele "capaz de controlar os indivíduos e as populações, tornando-os produtivos, adaptados, aptos e, ao mesmo tempo, inofensivos" (TOMÁS, 1996, p. 18). O ideal higienista de "bom cidadão" está diretamente associado a quem é "produtivo", assalariado, disciplinado à ordem hierárquica burguesa, inclusive fora do local de trabalho. Os que não cumpriam os padrões estabelecidos passaram a ser perseguidos e retirados do espaço "produtivo": “Os homens 'improdutivos', propensos à estagnação, passam a ser, portanto, evitados através da instituição do confinamento e do isolamento"(Ibid., p.16).

Os trabalhadores artesanais e os camponeses forçadamente proletarizados e urbanizados, tinham que se inserir na produção para poder garantir seus meios de subsistência. Entretanto, indústria não absorvia a todos, de modo que se impunha uma condição muito dura de reprodução da própria vida para uma fração considerável daqueles que tinham como único meio de subsistência a venda da sua força de trabalho. Engels (2010), observando esse contingente precariamente inserido na produção criou o termo "população supérflua", cuja vida ou morte era praticamente indiferente para a sociedade. Posteriormente, Marx (2017), usaria o conceito de "superpopulação relativa" para essa fração do proletariado ${ }^{267}$. Na concepção higienista, essa população seria

\footnotetext{
265 "Tais observações, exaustivamente já trabalhadas por Foucault, nos conduzem à ideia de que as medidas policiais adotadas contra uma epidemia visavam menos esta e mais seus efeitos deletérios em relação à ordem social e política estabelecida.” (Andrade, 1996, p.30) As jornadas de junho de 1848, de Paris, por exemplo, tiveram importante influencia para a reforma urbana de Hausmann.

${ }^{266} \mathrm{O}$ que na verdade é uma forma política não assumida de lidar com as questões.

${ }^{267} \mathrm{O}$ que explica a questão da superpopulação para Marx não é o excesso de pessoas no mundo e sim quantidade de pessoas que não são absorvidas pelo sistema produtivo e que por isso não tem acesso aos meio de subsistência. Trata-se de uma superpopulação relativa e não absoluta, isto é, não se trata do crescimento do número absoluto de pessoas e, sim do excedente de força de trabalho frente à capacidade de geração de empregos e acesso aos meios de subsistência. Esse conceito será mais trabalhado no último item desse capítulo.
} 
causadora de consequências indesejadas à cidade saudável, e seus indivíduos poderiam ser classificados como vadios, loucos, amorais, pela visão médica dominante.

O fato é que a sociedade produtora de mercadorias por mais que necessite de uma intensa mobilização de trabalhadores despossuídos para os centros de emprego, não incorpora a todos diretamente no sistema produtivo. Trata-se de uma população excedente útil como margem de manobra às "vontades do capital": necessária em períodos de expansão econômica, quando mais força de trabalho é empregada; em momentos estáveis, útil para rebaixar as médias salariais através da concorrência entre trabalhadores; e "descartável” em períodos de acirramento da crise econômica, quando as tensões sociais se agravam ${ }^{268}$.

Essa multidão busca sobreviver através de uma inserção precária (ou inexistente) na produção e, consequentemente, tem maior dificuldade de ocupar uma moradia nos padrões normatizados, o que torna sua existência, segundo a concepção higienista, uma ameaça ao conjunto social. Foi essa fração mais pobre da classe trabalhadora - e o espaço ocupado por ela - o alvo preferencial das ações sanitaristas. Nesse aspecto, a prática higienista assumia sua face evidente de higienização social. "Uma vez segregados da produção, passam automaticamente à condição de segregados do espaço urbano.” (TOMÁS, 1996, p. 21).

A lógica da urbanização sanitarista previa que a criação de instituições de confinamento - como os manicômios ou presídios - deviam situar-se às bordas do espaço urbano, isoladas por um cordão sanitário. Esses espaços eram destinados a receber todo tipo de cidadão "improdutivo" que, por motivos diferentes, não se enquadrava ao tempo abstrato do espaço urbano-industrial. A ideia de manda-los às margens parte do preceito de que a cidade seria um organismo e as suas bordas seriam poros, pelos quais expelem-se as impurezas. Evidentemente, a população mais pobre impedida pelas ações sanitaristas e pelo preço imobiliário de viver nas áreas mais centrais do espaço urbano - vai se alojar nas beiradas ("poros") das cidades ${ }^{269}$.

\footnotetext{
${ }^{268} \mathrm{O}$ constante desenvolvimento das forças produtivas também faz crescer a superpopulação relativa, através do desemprego estrutural.

${ }^{269}$ É possível afirmar que a região noroeste da RMSP cumpriu historicamente um papel de "poro", isolado da "cidade saudável" de São Paulo. Exemplo maior disso é o Hospital Psiquiátrico do Juqueri, onde, durante quase cem anos, foram confinados dezenas de milhares de "improdutivos". Também outros produtos "indesejados" da modernização foram encaminhados para a margem noroeste da cidade, como os lixões em Perus e Caieiras, que acumulavam (e ainda acumulam) os resíduos sólidos da modernização paulistana. É a população trabalhadora quem sofre com as doenças causadas por essa externalidade e ainda tem que protestar para não receber novos receptáculos de lixo. Outra estrutura indesejada no centro "saudável" da cidade, enviada à "borda" de Perus, foi o Cemitério de Indigentes (população supérflua), local onde se descobriu a vala clandestina de assassinados pelo regime militar.
} 
Resumindo as ideias desse subitem temos que: as contradições entre as classes na sociedade urbano industrial transcenderam o espaço das fábricas e se materializam nas péssimas condições de moradia dos trabalhadores. Quando essa contradição se transformou em riscos para a burguesia, o Estado passou a utilizar sua estrutura para intervir, tendo por base os preceitos higienistas. A segregação socioespacial - que já existia - foi agravada a partir da intervenção do poder público, que empurrou as moradias mais pobres para longe do centro da cidade. Por isso, a superação estatal proposta estaria limitada apenas a um espaço circunscrito, deslocando as contradições para fora do cordão sanitário da "cidade saudável”.

Podemos afirmar que a medicina social e a engenharia sanitarista falharam no objetivo de promover uma "sociedade saudável", a partir da organização racionalista do espaço. Como essas ciências instrumentais não englobam uma noção de totalidade, suas soluções só poderiam existir em níveis recortados, fragmentados. Não havia arcabouço científico suficiente no higienismo para se compreender a real origem dos problemas sanitários. "As insuficiências do higienismo derivam da impossibilidade de enfrentar as contradições inerentes a esta sociedade na qual estavam inseridos" (SEABRA, 2013, p. 12).

Havia a crença de que a presença do engenheiro seria uma garantia contra incoerências na construção e reconstrução da cidade. E o momento em que se passa a acreditar que, com o saber técnico, a cidade estaria controlada, disciplinada e saneada - na construção de uma utopia regada a obras esbeltas, sólidas e duráveis. (TOMÁS, 1996, p. 52)

A "solução espacial" é limitada quando se trata de problemas de origem social, econômica e política. Não se trata de um problema técnico. Todo desenvolvimento técnico e científico foi insuficiente para evitar a reprodução de condições sanitárias miseráveis. Mais do que não enfrentar as contradições sociais, a prática higienista cumpriu papel crucial para reproduzi-las, através da sua difusão enquanto representação ideológica $^{270}$ e da sua prática sobre o espaço como meio de realização do desenvolvimento desigual na escala urbana.

\subsection{Consideracões sobre o higienismo na cidade de São Paulo}

A partir da noção mais geral de higienismo apresentada no item anterior buscaremos fazer uma breve descrição histórica da prática higienista na cidade de São Paulo, percurso necessário para a compreensão do ambientalismo atual nessa cidade.

\footnotetext{
${ }^{270}$ Afinal são os interesses de valorização de valor que indicam a prática real da modernização e, não, o interesse por saúde pública.
} 
As ideias higienistas chegaram ao Brasil com a corte portuguesa, em 1808, antes mesmo de existir por aqui uma sociedade urbana industrial. Os médicos e engenheiros portugueses e brasileiros marcaram presença nos congressos ocorridos na Europa ao longo do século XIX e trouxeram novas ideias a respeito das questões sanitárias. Apesar de uma realidade completamente diferente, os modelos higienistas europeus foram sendo transpostos sem aprofundadas adaptações às especificidades ambientais e sociais das cidades brasileiras. Ideais fora do lugar (SCHWARZ, 1994) para um país rural, escravocrata, sem indústrias e com um ambiente completamente distinto do europeu ${ }^{271}$.

$\mathrm{Na}$ capital paulista, a partir da metade do século XIX, se definem mais claramente ações higienistas. O grande crescimento populacional da cidade - causado, especialmente, pela chegada de imigrantes, escravos/ex-escravos e fazendeiros - e a modernização - associada ao café, às indústrias de bens de consumo e ao imperialismo - foram as condições fundantes do higienismo em São Paulo.

O núcleo urbano colonial assentava-se sobre a colina, entre os rios Anhangabaú e Tamanduateí. As várzeas não eram utilizadas para construções e, de certa forma, barravam a expansão desse núcleo. Em 1848 começaram as primeiras obras de retificação e drenagem no rio Tamanduateí, um projeto para domesticar a dinâmica desse rio meandrante, de águas lentas, que causava enchentes indesejadas, "problema" não resolvido com essa ação. Desde então diversas outras intervenções nesse sentido foram realizadas nesse rio.

As várzeas de diferentes rios próximos ao centro urbano - em constante expansão - foram consideradas importantes focos de pestilências. Buscava-se sanear os rios cujas águas recebiam maior quantidade de esgoto e resíduos, pois, com avanço da urbanização, existiam riscos à saúde pública. Além disso, interessava às indústrias a domesticação dos rios para poder utilizá-los como força produtiva e, também ao mercado imobiliário, que vislumbrava novos espaços para valorização ${ }^{272}$.

Até então as várzeas, que eram espaços de lazer ou uso cotidiano, foram se transformando, recebendo novos usos, tornando-se ambientes inóspitos. A nova

\footnotetext{
${ }^{271}$ Nessa sociedade, predominantemente, negra, e de elites brancas, a transposição de ideias eugênicas ganhou força para justificar a dominação racial pós-abolição, de modo que a higienização social teve importante traço de higienização racial - especialmente em São Paulo, como veremos mais adiante.

${ }^{272}$ A aprovação da Lei de Terras, em 1850, foi fator essencial para alavancar intervenções sanitaristas sobre as várzeas, pois, a partir dela, a terra se tornou uma mercadoria no país. A situação geográfica cidade de São Paulo, centralidade financeiro comercial do Brasil, gerou um valorização exponencial para as novas mercadorias imobiliárias e fundiárias.
} 
ocupação dessas terras fluviais era associada diretamente aos trabalhadores mais pobres e à desordem.

As campinas verdejantes das várzeas, onde animais pastavam bucolicamente - e onde os paulistanos namoravam e passeavam, ou se banhavam e lavavam a roupa, conforme a ocasião - eram lugares que os rios requisitavam para suas águas, na época das chuvas. Com o súbito crescimento de São Paulo, esses lugares foram sendo rapidamente transfigurados. As antigas campinas das várzeas logo passariam a condição de "terrenos insalubres, infectos; lugar inseguro e de frequentação suspeita". (TOMÁS, 1996, p. 83)

Às obras sanitaristas de domesticação dos rios atingiram o Anhangabaú, o Tamanduateí ${ }^{273}$ e outros córregos por onde a malha urbana se expandia, no final do século XIX e começo do XX. A normatização higienista se consolidou através do Código de Posturas de 1886 e do Código Sanitário do Estado de 1894, que impuseram uma série de novas normas das quais merecem destaque a proibição de cortiços no centro da cidade (até então principal modo de morar da classe trabalhadora de São Paulo) e a proibição de costumes negros que, supostamente, significavam uma afronta à cultura e à limpeza da cidade.

Os pobres foram retirados das áreas centrais e de valorização imobiliária, foramlhes designadas as lonjuras da cidade ${ }^{274}$. "A higienização-e-modernização da área central da cidade, de fato, inaugura uma era de contínuo 'empurrar para adiante' os problemas da miséria.” (TOMÁS, 1996, p. 64). Nos extremos urbanos a físcalização sanitária não se fazia (tão) presente, ao contrário das áreas "embelezadas" do centro. Portanto, as práticas "anti-higiênicas" nunca foram abolidas da cidade. Além disso, segundo os códigos higienistas, matadouros, hospitais de isolamentos, entre outros tipos de usos do espaço deveriam ser "invisibilizados" e, necessariamente, estarem nas bordas da cidade.

A segregação socioespacial ganhava contornos na cidade de São Paulo. A possibilidade de extração de renda fundiária definia a hierarquização de suas áreas. As classes mais ricas ocupavam, normalmente, os topos de colinas, as "áreas secas" da região central em direção à zona sudoeste (áreas que receberam mais investimentos em infraestrutura), enquanto que as classes trabalhadoras tendiam a se alojar, notadamente, na parte leste da cidade e/ou em fundos de vale, ou ainda no cinturão suburbano, próximo às ferrovias e indústrias.

\footnotetext{
${ }^{273}$ Uma das intervenções sanitaristas sobre o Tamanduateí será analisada no item final deste capítulo.

${ }^{274}$ Isso foi feito de forma extraoficial, mas também oficialmente, com incentivo fiscal para quem produzisse casas higiênicas para trabalhadores em áreas afastadas do centro (ROLNIK, 1997).
} 
A expulsão dos pobres do centro foi também uma oportunidade de obtenção de ganhos imobiliários/fundiários em São Paulo e levou a extensão do tecido urbano:

A instalação das indústrias ao longo das ferrovias estimulava os operários a se estabelecerem em torno das estações ferroviárias fora da "cidade", onde poderiam adquirir terrenos, ou alugar casas, a preços mais baixos. Surge, assim, extenso "cinturão de loteamentos residenciais suburbanos", mais ainda escassamente edificados e ocupados. A enorme oferta de lotes baratos - pois distantes e desprovidos de benfeitorias urbanas -, podendo ser pagos à prestação, com a possibilidade de serem ocupados sem os custos e os aborrecimentos envolvidos na feitura e aprovação de uma planta e sem o risco de perturbação pela fiscalização, com acesso ao precário sistema de transporte público viabilizaram o mercado de loteamentos distantes e criaram uma alternativa habitacional de massa para os trabalhadores (BOTELHO, 2006, p. 241).

Chamamos a atenção para o fato de Botelho destacar que um dos motivos para os trabalhadores buscarem locais distantes do centro - como Perus, por exemplo - foi para se afastar do risco de perturbação pela fiscalização sanitária. Através dessa passagem se nota o descompasso entre os ideais higienistas (que se aplicavam às zonas centrais da cidade) e a realidade da maioria da cidade.

Nota-se que as medidas higienistas alavancaram dois produtos imobiliários distintos: as construções higiênicas do centro e os loteamentos para trabalhadores nos subúrbios. As ligações construídas para os novos bairros burgueses possibilitaram ganhos fundiários-imobiliários de grande monta. A produção de casas, quartos de aluguel e o loteamento de chácaras gerou ganhos para aqueles que detinham datas ou sesmarias, para aqueles que grilaram terras e para quem comprou terras ainda desvalorizadas, além é claro, de lucros para as empresas produtoras de imóveis. A demanda por moradia na cidade crescia exponencialmente, a população da cidade quadruplicou entre 1873 e 1893 (ROLNIK, 1997, p. 26), o que culminou em uma relativa raridade do espaço, que era disputado. Segundo Botelho (2006, p. 238), "entre 1887 e 1890 o preço médio dos terrenos em São Paulo teria triplicado”. As ações sanitaristas eram parte da disputa das classes pelo espaço urbano e, tiveram como efeito a valorização e a incorporação de novas terras ao mercado.

A expansão urbana logo levou as obras sanitaristas aos rios Tietê e Pinheiros. Essas intervenções evidenciaram a relação entre o higienismo e os negócios associados à criação de propriedades de terras. Segundo Seabra, o relatório da comissão de Melhoramentos do Tietê de 1926, já advertia sobre o fato de que "nas várzeas as cercas já andavam" (2013, p. 19), indicando a existência de interesses ligados à propriedade dos terrenos ribeirinhos, que envolvia entre outras práticas, a grilagem (Ibid.). A introdução no mercado das terras alagadiças das margens dos rios - realizada graças ao 
sanitarismo - mostrava-se, no início do século XX, uma importante fonte de lucros, inclusive transnacionais, como mostrado por Seabra (1986), através da ação da Light. Os habitantes que extraiam argila, areia ou pedregulhos desses rios ou mesmo o utilizavam para lazer, pesca ou para lavar roupas acabaram sendo expropriados nesse processo de formação de propriedade.

É possível afirmar que a transformação de rios e várzeas em forças produtivas reproduz uma dinâmica cíclica: mobilização da força de trabalho, segregação, expansão territorial, intervenções sanitárias, mobilização da força de trabalho, segregação... processo que se repete ao longo da metropolização de São Paulo. É claro que esse ciclo não se dá de forma evidente na realidade, até porque ele é pleno de contradições.

Também se pode reconhecer que a apesar de a modernização espacial ter gerado benefícios sociais (como a energia elétrica ou o parcial controle de enchentes, por exemplo) estes vieram acompanhados por um movimento de despossessão:

E, naturalmente os expropriados, proscritos nesse processo experimentaram nos seus corpos, o que de fato é o desenvolvimento desigual. Mas é assim que ocorre a socialização da natureza. Sim, porque, a subtração dos elementos do mundo natural (rios para navegação e alimento; várzeas com as argilas para tijolos e cultivos) ocorre em relação a indivíduos concretos, que não encontram os meios para experimentar alguma positividade nessas transformações. (SEABRA, 2013, p. 8)

Os negros, lançados à "liberdade" e, também os caipiras, foram alvos principais das práticas higienistas, notadamente da ação da polícia sanitarista, que reprimia seus costumes, sua não inserção na produção, sua pobreza etc. É possível afirmar que esses integravam a população supérflua brasileira ${ }^{275}$, frações mais pobres da classe trabalhadora que passaram, no imaginário social, a serem associadas à "vagabundagem" sendo muitas vezes responsabilizados por problemas sociais e ambientais. Vale ressaltar que parte da prática higienista firmou-se a partir da ideia de formação da "consciência sanitária”, de modo que, não cabia apenas ao Estado fiscalizar a população, mas também aos próprios cidadãos vigiar uns aos outros, fato que estimulou estigmatização a social de negros e caipiras ${ }^{276}$.

Higienismo, branqueamento da população e embelezamento das cidades eram ideias associadas à modernização do Estado-nação brasileiro ${ }^{277}$. Sob a influência de

\footnotetext{
275 Sendo que milhares deles foram enviados para reclusão no Hospital Psiquiátrico do Juqueri.

${ }^{276}$ Com a ascensão do higienismo suas ideias se popularizaram e se tornaram decisivas para a formatação da representação de cidade e cidadão "ideal" do senso comum. Por isso, afirmarmos que higienismo cumpriu um importante papel simbólico na reprodução das relações sociais.

${ }^{277}$ Em 1918 se institucionalizou a "Sociedade Eugênica de São Paulo", uma associação de intelectuais e políticos que buscava colocar o Brasil no "rumo do progresso". Dentre outras ideias absurdas esse grupo acreditava que para o Brasil se modernizar teria que passar por um branqueamento da população. Essa
} 
ideias higienistas e eugênicas, o espaço paulistano começou a ser tomado por chaminés, bulevares, hospitais de isolamento, casas higienizadas. Paisagem que se consolidava enquanto se combatia os focos de pobreza, os "maus hábitos" e se incentivava a imigração de não-negros. Esse era projeto para um "desenvolvimento saudável”. Assim, a São Paulo colonial foi destruída e reestruturada sob a lógica do urbanismo sanitarista.

Com o desenvolvimento das forças produtivas, ao ideal higienista somou-se outro paradigma modernizador e decisivo na forma como se apropriaram os rios na cidade de São Paulo: o rodoviarismo assentado sobre fundos de vale. Esse modelo de inserção dos rios no espaço produtivo começou a se estabelecer nos anos 1930, tornando-se hegemônico da metade até o final do século XX. Apesar de que parte das ideias higienistas foi perdendo crédito científico e social, ao longo desse século, elas não foram completamente superadas. Por isso, é possível classificar a solução de engenharia rodoviária de lidar com os corpos d’água urbanos como tributária das antigas práticas higienistas.

A opção por uma urbanização rodoviarista, assentada sobre a rede hídrica, levou a uma readequação espacial da cidade. A escolha do espaço das várzeas para receber as avenidas foi uma solução política e, também, econômica. Por serem pouco úteis à produção, se não domesticados, o Estado associou a intervenção sanitarista nesses espaços à produção de infraestruturas de circulação, garantindo assim, um aproveitamento produtivo para cada "palmo de chão" urbano. Essa foi uma solução mais barata, pois envolvia menos desapropriações ou desapropriações menos custosas, já que os terrenos não saneados eram menos valorizados. As avenidas de fundo de vale amplificaram a expansão da malha urbana e foram decisivas para a consumação do processo de metropolização. Isto posto, uma nova rodada de expropriação se configurou em distintos pontos da cidade onde as várzeas se transformaram em avenidas.

Nos anos 1980 e 1990, “o poder público municipal de São Paulo estabeleceu como estratégia conjugar as obras de canalizações de córregos à construção de avenidas, aproveitando a disponibilidade de recursos federais para obras de saneamento básico"278. (BIDERMAN et al., 2004, p.87) Isto é, a PMSP se aproveitou dos recursos do Planasa (Plano Nacional de Saneamento) para produzir parte das avenidas de fundo

noção, que já existia desde o século XIX, foi amplamente propagada por parte da elite e, inclusive, culminou em políticas oficiais de branqueamento. É possível especular que o estado de São Paulo foi o local da política de branqueamento mais efetiva.

278 As estruturas de saneamento tendem a acompanhar o percurso da rede hídrica, pois o esgoto se move pela força da gravidade até a estação de tratamento. 
de vale, fato que atesta a lógica de maximização de produtividade do espaço urbano, o que levou a "domesticação" e transformação em força produtiva de grande parte dos rios do centro expandido da cidade e adjacências ${ }^{279}$.

Tendo por base esse histórico de como a filosofia higienista embasou a forma de o Estado lidar com a população e com os rios na cidade de São Paulo, prosseguiremos nossa análise através da entrada de um novo paradigma na maneira como o urbanismo encara essas contradições, a "sustentabilidade".

\subsection{As moradias em fundo de vale e os parques lineares como política pública}

Os rios da metrópole de São Paulo chegaram ao século XXI sendo apropriados de duas maneiras principais: aqueles que receberam intervenção sanitária do poder público e aqueles que não. Os primeiros foram instalados em galerias subterrâneas e têm avenidas nas áreas de suas várzeas; os outros, em geral, são ocupados pela população pobre que aí se estabelece em favelas. Enquanto o primeiro grupo de rios está mais próximo das áreas centrais da metrópole, o segundo aparece, preferencialmente, nas periferias. "Raro é o curso d'água na área urbana que não apresente uma dessas situações.” (TRAVASSOS, 2010, p. 21).

Como visto no subitem anterior, a lógica sanitarista de intervenção teve papel crucial na configuração desse panorama e sua replicação continuada não alteraria em essencia esse quadro espacial. No entanto, no que se refere às intervenções sobre rios e várzeas, observamos, nos últimos vinte anos, um processo de mudança de padrão no planejamento urbano. Novas políticas públicas começaram a ser elaboradas e praticadas, a partir da filosofia ambientalista. Nesse sentido podemos questionar: essa mudança representa uma quebra de paradigma na lógica de apropriação dos rios urbanos?

Até a década de 1980 a filosofia ambientalista não era relevante nos planos urbanísticos. Somente a partir da regulamentação do Estatuto da Cidade (2001) foi que essa concepção de espaço começou a se tornar uma política pública ampliada, absorvida por instâncias e instrumentos de planejamento. Em 2002 apareceu no PDE de São Paulo a ideia de parque linear. Instrumento que faz parte de uma nova política espacial que visando o atendimento de critérios de sustentabilidade no urbano, e que tem como base

\footnotetext{
279 É importante ressaltar que, a partir dos anos 1990, as obras sanitaristas / rodoviaristas começaram a extrapolar a área do "centro expandido" de São Paulo. As avenidas Aricanduva e Jacu-Pêssego, na zona leste, e a Avenida Eliseu de Almeida, na zona Oeste, são exemplos disso.
} 
o argumento de que é importante "a convivência dos recursos naturais com os elementos construídos" (MIGLIACCI, 2016, p. 71).

Essa novidade teórica pode ser observável em números: no início do século XXI a cidade de São Paulo contava com cerca de 30 parques, a maioria originada através de terrenos sem construções incorporados à municipalidade. Atualmente, já existem 105 parques na cidade ${ }^{280}$, tipificados entre urbanos, naturais e lineares. O grande salto ocorreu em 2008, através da criação do programa "100 parques para São Paulo". A partir de então a modalidade "parque linear" passou realmente a ser uma política pública da $\mathrm{PMSP}^{281}$. Diferentemente do período anterior, os parques desse programa passaram a ser implantados em algumas áreas ocupadas, exigindo, portanto, desapropriações e remoções. Nota-se que a prioridade da política de parques lineares é que esses sejam instalados nos extremos de todas as regiões do município, sobretudo Norte, Sul e Leste ${ }^{282}$ (Ver Mapa 8).

As obras (públicas e privadas) de dominação do espaço natural do sítio urbano de São Paulo trouxeram, desde o século XIX, a necessidade de se lidar com as águas. Desde então esse é um problema central no processo de urbanização, que se manifesta através do assoreamento e enchentes dos corpos d'água, do grande índice de moradias sem saneamento básico e da disponibilidade de água tratada.

O processo de modernização da sociedade progrediu de modo a ocupar as áreas de várzeas, reduzindo os espaços das águas. A crescente impermeabilização do solo, associada à difusão das canalizações de riachos e córregos, levou a uma vertiginosa aceleração no escoamento das águas pluviais e fluviais. As obras de retificação dos rios - que extinguiram seus meandros - diminuíram a extensão dos canais, acelerando assim o fluxo das águas. Todos esses fatores se somam e colaboram para o aumento do volume de material sólido que chega às calhas dos corpos d’água, gerando um constante processo de assoreamento. Os problemas de coleta de lixo também contribuem para isso. As obras de aprofundamento das calhas - nos rios principais - não se mostraram suficientes para controlar as enchentes, como os engenheiros previram que seria possível.

${ }^{280}$ Dados oficiais da PMSP, no entanto, um pouco inflados, pois em alguns casos são contabilizadas as distintas fases de implantação, de um mesmo parque, como se fossem parques diferentes. Contudo, vale a reflexão sobre o porquê de se superestimar esses dados.

${ }^{281}$ Atualmente, a cidade conta com 24 parques lineares implantados e mais uma série em implantação ou projetados (ver Mapa 8).

${ }^{282}$ Em consonância com essa mesma política pública, o atual Plano Diretor de São Paulo prevê a criação de mais 167 parques, de modo que a cidade contaria 272 parques até 2030, sendo 107 classificados como parques lineares. 
Mapa 8 - Parques lineares planejados e implantados no município de São

\section{Paulo (2014)}

PaRques LiNeARES PLANEJAdos E Implantados

Esc. 1: 390,000

N.

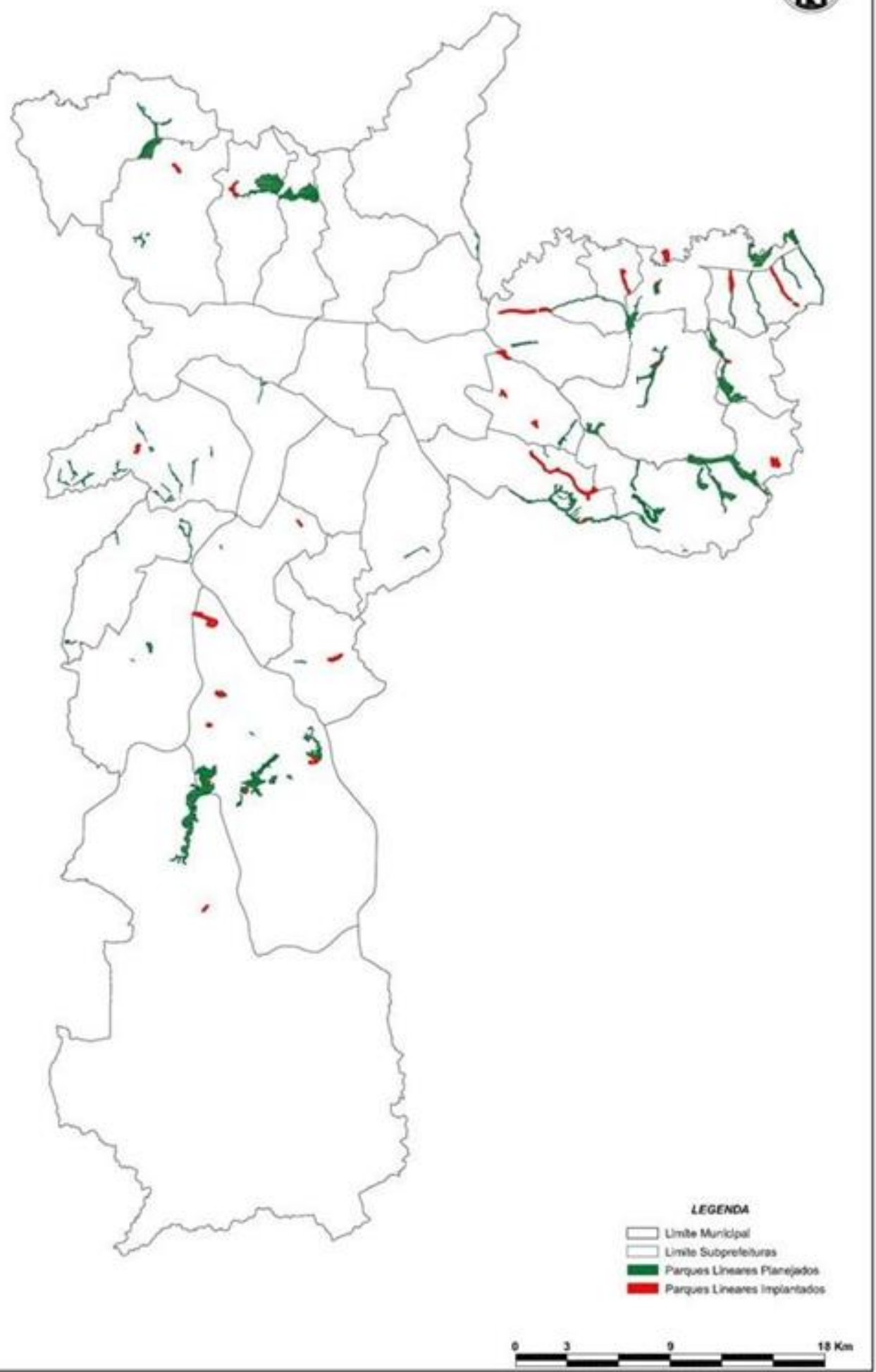

Fonte: Migliacci, 2016, p. 73 (adaptado).

É diante desse quadro que, a partir da década de 2000, a rede hídrica passou a ser considerada "elemento estruturador e de transformação urbanística" no planejamento da cidade. Essa estratégia propõe áreas verdes nos fundos de vale, no 
intuito de criar o que vem sendo chamado de "infraestruturas verdes". Os parques lineares seriam instrumentos chave dessa política.

O conceito desse tipo de parque parte do pressuposto de "restauração dos rios" localizados em áreas urbanas, a fim de criar corredores ecológicos que liguem as manchas de vegetação da cidade. Uma das justificativas para essa política pública seria a de conformar uma rede de terrenos que possibilitasse o movimento e a fluidez de pessoas, animais, sementes, água, entre outros elementos.

A definição do que é um parque linear torna-se mais ampla, pois segundo o atual PDE essa seria uma solução intersetorial para distintos objetivos: ecológico; recreacional; cultural; habitacional; estético; saneador; de mobilidade etc ${ }^{283}$. No entanto, um parque linear dificilmente pode dar conta desses múltiplos objetivos sem contradições. Há conflitos, por exemplo, entre a proteção à vida selvagem e o espaço recreativo, ou ainda, entre o embelezamento urbano e o controle de inundações. Por isso, dentro desse instrumento urbanístico ambiental se estabelecem diferentes tipos de projetos, definidos de acordo com seu objetivo prioritário. Essa é uma questão chave para a compreensão da implementação desse instrumento no Brasil.

Tanto Migliacci (2016), quanto Travassos (2010) constatam em suas pesquisas que as instituições públicas brasileiras passaram a incorporar os ideais "sustentáveis" de urbanismo, a partir de modelos estadunidenses e europeus ${ }^{284}$. Contudo, essa inspiração nos países centrais ocorreu sem uma aprofundada reflexão sobre as condições de formação das cidades em um país periférico, com características bastante distintas dos locais para aonde foram concebidos os parques lineares ${ }^{285}$.

Travassos (2010), estudando atentamente a adaptação dos projetos de parque linear para a cidade de São Paulo, afirmou que as obras realizadas pela PMSP tiveram como modelo principal os projetos propostos pela Soil Conservation Service, empresa

\footnotetext{
283 “Art. 273. Os parques lineares são intervenções urbanísticas associadas aos cursos d'água, principalmente aqueles inseridos no tecido urbano, tendo como principais objetivos: I - proteger e recuperar as áreas de preservação permanente e os ecossistemas ligados aos corpos d'água; II - proteger, conservar e recuperar corredores ecológicos; III - conectar áreas verdes e espaços públicos; IV - controlar enchentes; V - evitar a ocupação inadequada dos fundos de vale; VI - propiciar áreas verdes destinadas à conservação ambiental, lazer, fruição e atividades culturais; VII - ampliar a percepção dos cidadãos sobre o meio físico. $\S 1^{\circ}$ Os parques lineares são parte integrante do Programa de Recuperação Ambiental de Fundos de Vale e sua plena implantação pressupõe a articulação de ações de saneamento, drenagem, sistema de mobilidade, urbanização de interesse social, conservação ambiental e paisagismo" (SÃO PAULO, 2014).

${ }^{284}$ A partir dos anos 1990, diretivas da União Europeia passaram a enfatizar a sustentabilidade urbana como um parâmetro importante para os países do bloco. Desse modo a questão ambiental passou a integrar o planejamento territorial de diversos países.

${ }^{285}$ São muitas as diferenças no que se refere às condições espaciais, sociais, políticas, econômicas etc.
} 
privada estadunidense, especialista em preservação e restauro de recursos naturais (Ibid., p. 74).

Um ponto central, pouco elaborado nos projetos brasileiros é a condição de moradia da classe trabalhadora, que é muito distinta da realidade dos países centrais. A espoliação urbana, característica das cidades brasileiras, consolidou a apropriação das margens de rios pelos pobres como modo de morar ${ }^{286}$. Esse fato, característico de um país periférico, não é - nos projetos de parques lineares originalmente concebidos considerado como uma das variáveis principais e a adaptação brasileira destes também trata essa questão como lateral ${ }^{287}$.

A espacialização periférica dos parques lineares na cidade de São Paulo faz coincidir a implantação desses equipamentos com as ocupações mais pobres. Fato pode ser explicado por alguns motivos. O mais simples seria que nessas áreas que se encontram os corpos d'água ainda com canais abertos, não saneados. A segunda razão seria o custo para implementação dos parques, muito maior nas áreas consideradas centrais, por conta dos onerosos dispêndios necessários para desapropriações de imóveis. Nesse sentido, os parques nas periferias se justificariam por ser uma opção mais "econômica" para o Estado, visto que o preço das terras é mais baixo nesses locais $^{288}$. Sobre essa questão é imperativo abrir um parênteses para reflexão.

Como descrito no item anterior, no processo de expansão espacial da metrópole as áreas próximas aos rios são mais desvalorizadas, de modo que abrigam as populações de menor renda até o momento em que recebem obras de engenharia, se valorizam, e se criam as condições para a sequência do processo de valorização na área do entorno. Dessa forma, os rios mais centrais - que outrora eram desvalorizados - hoje, após serem “domesticados", se tornaram áreas tão valorizadas que se argumenta que é inviável para a PMSP descanalizá-los para criar parques lineares. Isto é, os investimentos do passado tornam-se um impeditivo à adaptação desses corpos d’água ao padrão do novo

\footnotetext{
${ }^{286}$ De acordo com a Sehab, em 2009, o município de São Paulo tinha 1.637 favelas, das quais 569 se encontravam sobre áreas de várzea ou leito de rios, totalizando mais de 224 mil domicílios nessas condições (SÃO PAULO, 2009). Para 2018, a Sehab apresentou o dado de 1.715 favelas cadastradas, não informando quantas estavam sobre várzeas ou rios (disponível em < http://www.habitasampa.inf.br/habitacao/ > Acessado em 13 de outubro de 2018).

${ }^{287}$ Como na introdução do higienismo no Brasil, novamente podemos vincular a prática do planejamento urbano ao conceito de ideias fora do lugar.

${ }^{288}$ Associa-se a esse motivo o fato de que a população que ocupa esses espaços, em geral, possui menor conhecimento legal sobre seus direitos e, também, menos capacidade de contratar um suporte jurídico para garanti-los. Esse fato conflui com a "opção econômica" para instalar esse tipo de parque nas periferias, pois a PMSP muitas vezes acaba gastando menos com indenizações por remoção do que gastaria, caso houvesse maior resistência jurídica e política por parte dos afetados.
} 
urbanismo "sustentável", mesmo que atualmente essa seja a forma de intervenção considerada, pelos próprios planejadores, como a mais "adequada".

A terceira razão que nos ajuda a compreender o porquê da espacialização dos parques lineares na cidade de São Paulo tem relação direta com anterior. Como as obras sanitaristas e rodoviaristas colaboraram decisivamente para a valorização de áreas da cidade, também os parques lineares contribuem para a inserção de terras nos circuitos de valorização. O fato de essas obras serem projetadas, de preferência, em áreas ocupadas pelas frações mais pobres da classe trabalhadora - que, muitas vezes, contam apenas com a posse e, não a propriedade, do imóvel - torna mais barata a implantação dos parques. Assim, a incorporação desses espaços ao mercado imobiliário formal acaba afastando essa população desse espaço beneficiado pelo parque. Ações como essa, induzidas pelo Estado, podem levar à criação de novas centralidades em áreas historicamente desvalorizadas da metrópole. Dessa forma, se configura uma estratégia de valorização do espaço que ressignifica espaços periféricos da metrópole, sem necessariamente investir em desapropriações gigantescas e custosas, o que contribui para um processo de reestruturação imobiliária. A estratégia espacial do Estado se dá através de intervenções precisas, em espaços restritos, gastando menos dinheiro e desencadeando um processo de gentrificação nas suas adjacências.

Nesse sentido o próprio Plano Diretor (SÃO PAULO, 2014) enfatiza que um dos objetivos dos parques lineares é criar condições para atrair negócios imobiliários em novas áreas de expansão urbana.

Art. 107 - (...) II - ampliar os espaços de lazer ativo e contemplativo, criando progressivamente parques lineares ao longo dos cursos d'água e fundos de vales não urbanizados, de modo a atrair, para a vizinhança imediata, empreendimentos residenciais;

Isto é, o projeto de introdução dos fundos de vale periféricos no circuito formal de valorização em ocorreria associação ao novo produto imobiliário: o condomínio em que se pode contemplar o "verde".

Essa estratégia aparece como "palatável" ao senso comum, pois esses espaços são facilmente taxados como locais "degradados" que merecem ser "revitalizados". Fato que torna essa estratégia difícil de ser criticada dada a confusão de representações que ela envolve: Como uma ação que busca preservar o meio ambiente e atuar sobre um espaço "deteriorado" pode ser causadora de problemas? A "cidadania-bloco ambiental" relega ao segundo plano (ao "invisível") a grave situação social das pessoas que foram (ou serão) deslocadas. Reafirma-se a espetacularização do ambientalismo. 
Além disso, há também os parques lineares que foram implantados em áreas onde não havia moradias, cuja lógica é semelhante, porém com o impacto social direto, menor. Do ponto de vista das estratégias, cumprem a função de inibir possíveis novas ocupações, operando como um fator de controle do uso do solo urbano ${ }^{289}$.

Passemos, portanto, a refletir sobre a abordagem dos projetos de parques lineares para a questão da moradia em fundos de vale, elemento chave na compreensão de suas contradições. Como destacado anteriormente, a estratégia de maximização dos lucros a partir da negligencia com as condições de moradia da classe trabalhadora é característica decisiva da urbanização brasileira. Os instrumentos legais elaborados para proteger os fundos de vale não foram efetivos diante da crescente demanda por moradia nas cidades e o crescimento populacional nesses espaços vem ocorrendo a taxas maiores do que em outras partes do relevo da cidade de São Paulo ${ }^{290}$ (TRAVASSOS, 2010, p. 96).

Por conta disso, para a execução das obras dos parques lineares é praxe a remoção de famílias. Como já destacado, a abordagem da questão da moradia não é quesito central nos projetos adotados pela PMSP. Ou seja, dentre os vários objetivos a que se propõem os parques lineares um dos menos prioritários é aquele relacionado à questão de moradia adequada à classe trabalhadora, o que compromete os próprios objetivos ecológicos dessa política.

A diretiva geral da Sehab para os projetos públicos habitacionais é de se buscar elaborar um projeto que remova o menor número de famílias possível e que essas sejam

\footnotetext{
${ }^{289}$ No item 3.5 foi relatado um exemplo desse controle no córrego da Mina. Outro exemplo: na área do Parque Linear Perus já desapropriada, mas sem receber nenhuma obra, no sul do distrito, foi realizada uma reintegração de posse a pedido da SVMA, pois estava se instalando um loteamento irregular nesse terreno. Retirado de

http://www.prefeitura.sp.gov.br/cidade/secretarias/meio_ambiente/noticias/?p=237212 > Acessado em: 17 de janeiro de 2018. Em acordo com essa hipótese, Rizzi (2011b, p. 34) afirma que "O planejamento dos parques lineares em Perus foi realizado visando, acima de tudo, impedir e reduzir o alastramento da urbanização desse tipo de população para o restante do espaço ocupado do distrito".

290 "No ponto crítico perto de $20 \%$ da população de São Paulo estava morando em favelas. Desse total $65 \%$ em terrenos públicos. E, mais da metade das favelas localizando-se nas beiras de rios e córregos, sendo que 30\% delas em terrenos de acentuada declividade." (Seabra, 2013, p.23). Em pesquisa recente, o IBGE divulgou que 8,3 milhões de pessoas vivem em áreas de risco no Brasil, sendo cerca de 674 mil na cidade de São Paulo. Retirado de < https://www.ibge.gov.br/geociencias-novoportal/organizacao-doterritorio/tipologias-do-territorio/21538-populacao-em-areas-de-risco-no-brasil.html?=\&t=publicacoes > Acessado em: 21 de agosto de 2018. Além da legislação de proteção dos corpos d'água em geral, a Lei de Proteção dos Mananciais - localizados na zona sul do município de São Paulo e ao norte, na Cantareira intentou evitar o adensamento populacional nessa áreas, através do impedimento do parcelamento dos terrenos para a produção de loteamentos, o que foi ineficaz em seu objetivo. Após sua promulgação, os terrenos se desvalorizaram no mercado, situação que "somada ao grande déficit habitacional estimulou a ocupação massiva em certas áreas com habitações precárias e irregulares, sujeitas às situações de risco" (SEABRA, 2013, p.25). Atualmente, tanto na região das represas Guarapiranga e Billings assim como no entorno da Serra da Cantareira, existem áreas densamente ocupadas.
} 
alocadas no mesmo distrito, ou o mais próximo possível. Entretanto, essa premissa é relativizada diante de uma prerrogativa ambientalista autonomizada - que separa o que seria o "estritamente ambiental" do social - que em diversos casos solicita um número maior de realocações para que se realize um projeto que dê maior valor à dimensão ambiental - como relatado no caso do Complexo do Bamburral.

Travassos (2010) em sua análise geral sobre a política de parques lineares em São Paulo mostra como, em diversos casos, que o provisionamento habitacional proposto pela PMSP é insuficiente para garantir o direito à moradia adequada, visto que o principal instrumento utilizado para efetivar a remoção tem sido o pagamento de indenizações às famílias, tanto o auxílio-aluguel quanto a indenização única. Essa última varia entre $\mathrm{R} \$ 5$ mil e $\mathrm{R} \$ 8$ mil na maioria dos casos, podendo chegar a valores maiores em algumas exceções. Segundo o levantamento de Travassos (2010), somente nos parques lineares Canivete, Itaim e Ribeirão do Fogo, por exemplo, 1.743 famílias foram removidas de suas casas, sendo que cerca de 1.264 habitacionais ${ }^{291}$ ou estão à espera disso, recebendo auxílio aluguel mensal de $\mathrm{R} \$ 400,00$ receberam a indenização única. As outras famílias ou foram realocadas em conjuntos.

É notável que as indenizações por remoção tenham sido a política habitacional mais abrangente da cidade de São Paulo, sendo que, nas últimas décadas, dezenas de milhares de famílias foram objeto desse instrumento. Atualmente 28.382 famílias recebem auxílio-aluguel no município ${ }^{292}$, sem contar os que receberam indenização única e para os quais não há contabilização publicada.

Nossa hipótese é que a política de remoções em vigor faz parte do processo de reestruturação imobiliária e fere, em muitos casos, os marcos legais conquistados pelos movimentos sociais urbanos: "As conquistas no campo do direito à posse da terra desses assentamentos são ignoradas e tratadas de maneira ambígua e discricionária. Ou seja, espoliam-se os ativos dos mais pobres, sem reconhecer seus direitos, porque é mais barato" (ROLNIK, 2012, s.p.d. apud ALVAREZ, 2014, 293).

É necessário reafirmar que as remoções forçadas não são um fenômeno pontual na urbanização de São Paulo. Entre 2010 e 2016, segundo o Rolnik et al. (2017, p. 12), 65.798 famílias foram removidas de suas casas nos municípios de São Paulo e do

\footnotetext{
${ }^{291}$ Muitas vezes as famílias são deslocadas para conjuntos habitacionais muito distantes do bairro onde foram removidas, como, por exemplo, o caso do Parque Linear Canivete, próximo ao Parque Estadual da Cantareira, zona norte, onde famílias foram realocadas para a Cidade Tiradentes, zona leste.

292 Retirado de <http://www.habitasampa.inf.br/php/pdfs/auxilioaluguel/auxilioaluguel.pdf> em 13 de setembro de 2018.
} 
$\mathrm{ABC}^{293}$. Outras 222.128 estão sob ameaça de remoção. A implantação de parques tem papel destacado nesse processo. Das 868 comunidades com casos registrados de ameaça ou efetivação de remoção, 165 (19\%) tem como justificativa a "implantação de áreas verdes”. Essa é, portanto, a segunda razão que mais gera remoções na metrópole, atrás apenas das "urbanizações de favela ${ }^{294 "}(47 \%)$ e à frente, por exemplo, das "áreas de impacto de operações urbanas" (12\%) (Ibid., p. 13).

\section{Mapa 9: Distribuição territorial dos assentamentos ameaçados ou removidos na conforme motivo alegado.}

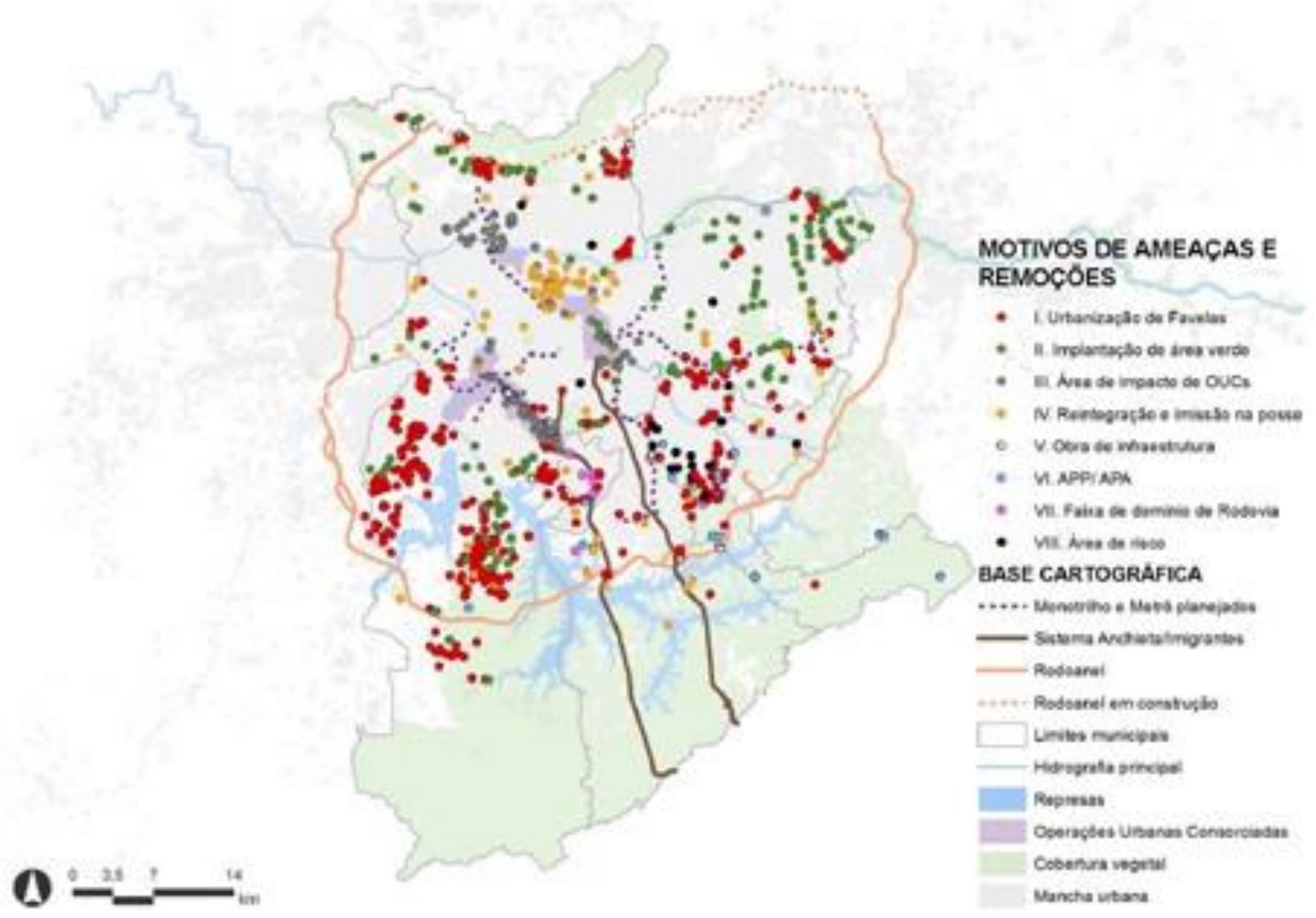

Fonte: Rolnik et al., 2017, p.14

Dados referentes aos municípios de Santo André, São Bernardo do Campo, Diadema, Mauá, e São Paulo.

\footnotetext{
${ }^{293}$ Especificamente os municípios de Santo André, São Bernardo do Campo, Diadema, Mauá, além de São Paulo.

${ }^{294}$ Como já ressaltado, o paradigma dos parques lineares influencia também os projetos de "urbanização de favelas", como visto, por exemplo, no caso da urbanização do Bamburral, ou nas propostas para o córrego do Recanto do Humildes.
} 


\section{Mapa 10: Distribuição territorial das ameaças de remoção e remoções devido a implantação de área verde, no município São Paulo}

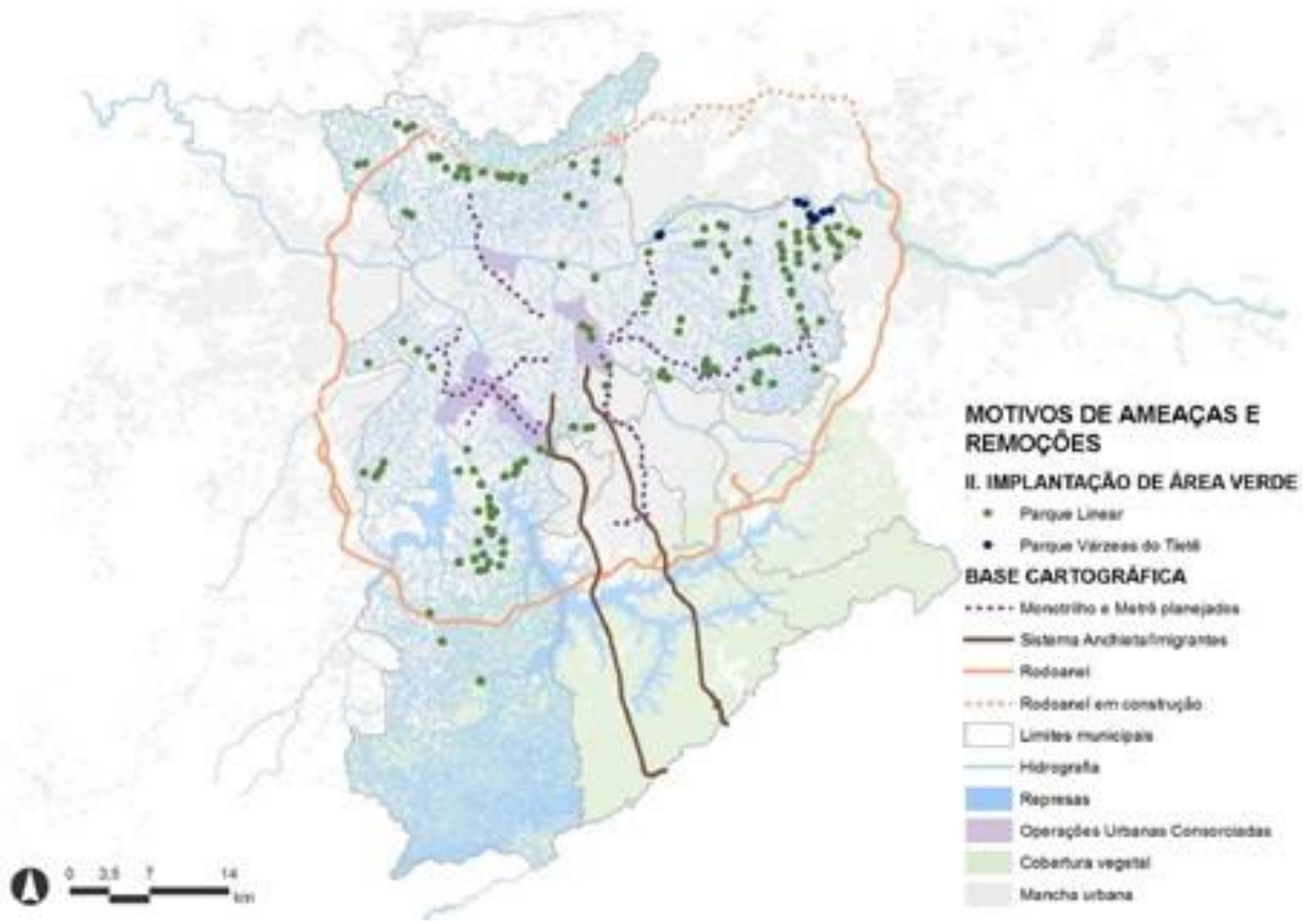

Fonte: Rolnik et al., 2017, p.16

Esses dados evidenciam que as remoções sustentadas por motivos ambientalistas não são um fenômeno lateral no atual processo de urbanização e que está em curso um processo de "gentrificação verde". As indenizações pagas são insuficientes para que os removidos consigam garantir condições de moradia adequadas, de modo que o próprio objetivo ecológico dos parques lineares fica completamente comprometido por conta do profundo "descaso" com a questão das condições de moradia, como destaca TRAVASSOS (2010, p. 200):

É possível, inclusive, que terminem por ocupar outras áreas públicas: talvez em áreas de risco, às margens de outros córregos da região, à montante ou à jusante do mesmo córrego, ou talvez adensando algum assentamento precário nas franjas metropolitanas, em fundos de vale de áreas duplamente protegidas - pelo Código Florestal e pela Legislação de Proteção aos Mananciais ou pelo mesmo código e gravadas como áreas de controle de crescimento por questões de drenagem - em municípios que contam com menos recursos financeiros para solucionar o problema. Não se sabe, uma vez que não há nenhum tipo de acompanhamento a essas pessoas. 
A irracionalidade do ambientalismo espetacularizado ganha forma didática para a compreensão de sua vertente urbanística. Citando um exemplo concreto a pesquisa na Brasilândia de Angileli que atesta que a implantação do Parque Linear Canivete culminou com avanço da ocupação em direção a áreas protegidas e de risco da Serra da Cantareira.

De acordo com estudos de campo realizados por Angileli (2008-2012), a remoção realizada através de um atendimento habitacional inadequado, contribuiu para a formação de uma nova favela denominada Tribo e com o adensamento da ocupação Fazendinha, também localizada em áreas de risco, nas encostas da pré-Serra da Cantareira (SANDEVILLE e ANGILELI, 2013).

Para o extremo sul da cidade - onde o "projeto" de precarização da moradia da classe trabalhadora gerou complexos problemas socioambientais nas cercanias das represas - a política urbanística "sustentável" se faz muito presente. O documentário "Reservatório de Tensões ${ }^{295 "}$ relata uma série de contradições envolvidas nesses projetos. Dentre outras informações é mostrado que parte dos removidos para a implantação do Parque Linear Cantinho do Céu mudou-se para outras partes da própria área de mananciais. Ainda há nesse documento, o registro de que houve remoção e demolição de casas para a extensão desse parque, mas obras foram abandonadas pela PMSP. Sobre os escombros das antigas moradias foi construída outra ocupação.

Ora, as remoções que garantiram a criação dos parques lineares acabaram por recolocar e, até agravar, o problema ambiental. A expropriação e mobilização do trabalho, instauradas por esse processo, trazem consigo uma forte tendência de que parte dos removidos se desloque para áreas protegidas pela legislação ambiental, não ainda ocupadas (ou menos densamente ocupadas), por conta do valor das indenizações Desse modo, as péssimas condições de moradia são reproduzidas, assim como as ocupações em fundos de vale e em áreas de risco.

Portanto, não é possível afirmar que a política de parques lineares tem configurado uma salvaguarda de melhoria ambiental urbana. Pelo contrário, na medida em que ela estimula o avanço da ocupação sobre terrenos da borda da bacia de São Paulo - atingindo áreas de maior declividade e a cabeceiras de córregos - o risco de catástrofe se acentua ${ }^{296}$.

\footnotetext{
295 Elaborado pelo coletivo "Periferia em Movimento", em 2018. Disponível em < http://periferiaemmovimento.com.br/extremo-sul-um-reservatorio-de-tensoes/ >, Acessado em: 03 de setembro de 2018.

${ }^{296}$ Há uma hipótese, disseminada em outros trabalhos, de que esse tipo de remoção, sem garantias de moradia adequada para os atingidos, faz parte de uma estratégia de expansão urbana e de incorporação de novas terras ao mercado imobiliário regular, valendo-se da população mais pobre como ponta de lança do
} 
Não é novidade que as formas possíveis de sobrevivência das classes mais pobres dependa da ocupação dos terrenos urbanos mais inóspitos, como os fundos de vale ou as encostas íngremes. Evidentemente, esse não é um fenômeno natural - por mais que seja naturalizado. Nem tampouco é um ato de má fé dos indivíduos "optar" por morar na área de enchente dos rios. Mas, ao analisarmos os projetos de planejamento ambiental, notamos que a ideia de "sustentabilidade" se tornou quase que um sinônimo de remoção dessas pessoas de suas casas. Fato que deveria vir acompanhado de provisionamento habitacional adequado para os afetados (como estabelecido por lei). No entanto, como aqui ressaltamos, esse compromisso do poder público muitas vezes é falacioso e/ou longínquo. Assim, apesar de se derrogar uma filosofia para além das classes sociais - preocupada com as gerações futuras -, a "sustentabilidade" assume um conteúdo de classe.

Dito isso, é pertinente reiterar que não se advoga aqui a perpetuação de moradias precárias em áreas de várzeas, pois é perfeitamente justificável que alguns espaços não devam ser ocupados com moradias por conter riscos geológicos, de enchentes, por abrigar um remanescente de vegetação etc. Por essas características, seria adequado que esses espaços recebessem usos específicos compatíveis. Entretanto, a política pública ambiental desenhada para a cidade São Paulo é reducionista, pois prevê soluções "sustentáveis" localizadas em perímetros de projetos específicos e fragmentadas do todo, atestando, de saída, sua própria ineficácia. Outros autores, também chegam a formulações semelhantes:

Não se questiona neste artigo o problema ambiental decorrente da ausência de cobertura vegetal e permeabilidade do solo que diminui a absorção da água pluvial, contribuindo para o assoreamento dos mesmos e, portanto, enchentes mais frequentes (...). O que se questiona é a avaliação insuficiente dos problemas sociais, decorrentes da prática de implantação desses projetos, que dissocia o meio ambiente e as pessoas (SANDEVILLE e ANGILELI, 2013).

A "sustentabilidade", assim como o higienismo, também é incompetente para teorizar sobre a totalidade, de modo que as políticas derivadas dessa filosofia simplesmente reiteram o problema que, supostamente, busca combater ${ }^{297}$.

processo, que, através da sua ação de autoconstrução e reivindicação por infraestrutura urbana, realiza o trabalho de transformar um espaço "vazio" em urbano.

297 O planejamento fragmenta o espaço, cada vez mais em um recorte menor, tomando esses retalhos como uma totalidade em si. A crescente fragmentação da realidade se torna uma prática política comum do Estado que visa - dentre outras coisas - mascarar as contradições, tornando-as separadas (DEBORD, 1997), como se elas não estivessem ligadas ao movimento global de reprodução da sociedade. 
É importante esclarecer ao leitor que tampouco é objetivo dessa dissertação argumentar contra a existência de espaços livres para uso público na cidade. Há um reconhecimento de que a cidade carece de áreas verdes, de espaços para esportes, para lazer, para convívio social - especialmente nas áreas periféricas. No entanto, como assinala Migliacci, a questão da raridade do espaço é básica para se pensar sobre o assunto: "em uma cidade como São Paulo, em que a raridade do espaço se torna cada vez mais presente, para que se tenha esse espaço livre é preciso "construí-lo", ou seja, demolir construções existentes." (MIGLIACCI, 2016, p. 67) E as construções escolhidas para serem demolidas para este fim têm sido as casas das pessoas mais pobres. A nosso ver o conceito de parque linear apropria-se das ideias de "catástrofe ambiental" e de "apropriação de um espaço público" para justificar uma política de remoções e gentrificação ${ }^{298}$, fenômeno que vem sendo denominado como processo de "gentrificação verde".

A crítica a que se pretende esta dissertação avança no sentido de apontar que essa fração da classe trabalhadora tem o direito de estar no urbano negado, sistematicamente. Mesmo sendo um acesso precário e hostil, ele é negado. Afinal, as políticas públicas que mais assertivamente as atingem são as de remoção. Para esse grupo social, em estado de "temporariedade permanente", ocupar áreas inóspitas de um bairro relativamente bem localizado pode significar, em um momento seguinte, ser expulso para uma periferia mais distante, sob o risco de ocupar uma área tão inóspita quanto a anterior.

Os produtores do espaço construído oferecem ao trabalhador um conjunto limitado de condições de vida. Dessa forma, o trabalhador tem que se virar com aquilo que consegue - habitações precárias e sem infra-estrutura, por exemplo. Nesse sentido a melhoria nas condições de vida é uma batalha constante, tanto no ambiente de trabalho como no espaço de moradia, que vai sendo escamoteada ou confundida pelo ambientalismo. (SEABRA, 2013, p.26)

Há um processo contínuo de expropriação em curso, que impede a classe trabalhadora de ter condições de vida mínimas. A dinâmica segregacionista do higienismo parece se renovar.

\footnotetext{
${ }^{298}$ É significativo destacar que a criação de parques, muitas vezes, funciona como "álibi" para a realização de políticas antipopulares: "como elementos de dinamização da economia urbana, os parques públicos parecem acentuar a segregação social, funcionando como 'álibis' de determinadas politicas de intervenção urbana", pois essas áreas são "elementos de valorização do espaço urbano e contribuem para um processo de substituição de população nas áreas requalificadas. Eles tornaram-se álibis para justificar 'grandes transformações fisicas e sociais dos bairros afetados' pelas operações de requalificação urbana. Álibis, porque os parques públicos sempre representaram e expressam valores éticos e estéticos, que ultrapassam largamente seus limites espaciais". (SERPA, 2005, apud, MIGLIACCI, 2016, p. 66).
} 
Migliacci (2016), ao estudar o parque linear do Rio Verde, na zona leste, defronta-se com o fato de haver um terreno sem uso que não foi desapropriado para o parque, enquanto outro espaço ocupado por moradias foi designado para ser removido. Diante disso, a autora questiona qual o real sentido dessa ação "sustentável":

Questiona-se, assim, qual o sentido de desapropriar áreas ocupadas, sem
vegetação para implantar um parque e ao mesmo tempo não desapropriar
outras áreas com vegetação e que seriam mais propicias a preservação?
Seriam as desapropriações uma ação no sentido de eliminar usos
indesejáveis, contribuindo, assim, para a valorização desta área sob
requalificação urbana? ${ }^{299}$ (ibid., p. 83)

O número elevado de remoções, o baixo valor das indenizações, associado à vulnerabilidade das famílias removidas indicam que o projeto urbanístico sustentável, tal como está colocado, tem um caráter de higienismo social e de agravamento dos problemas ambientais.

Não se questiona a necessidade de se buscar alternativas para a melhoria da qualidade ambiental dos espaços urbanos. Contudo, essa constatação não pode apagar o fato de que há nesses "projetos urbanísticos ambientais" uma ideia seletiva e eugênica do que é sustentável.

Se realmente os parques lineares buscassem a possibilidade de conciliar o direito à moradia e preceitos ambientalistas - mesmo que dentro dos limites da tecnocracia seria primordial partir-se do pressuposto de que a classe trabalhadora tem que conseguir acessar condições adequadas de moradia. Essa prioridade não seria apenas uma opção política, mas também uma ação necessária para que as medidas ambientais pudessem ter algum efeito.

Peça maneira como os parques lineares estão sendo implantados em São Paulo, gerou-se uma falsa oposição entre os trabalhadores de baixa renda e a preservação do meio ambiente. A forma fragmentária com que a tecnocracia sustentável aborda a questão é causadora de remoções diretas e indiretas, ocasionando o agravamento da questão da moradia e a deterioração de áreas preservadas.

Travassos, ao buscar uma solução diante das diversas contradições, se defronta com o limite das soluções institucionais do "limite de verbas":

Como promover o número de unidades habitacionais necessárias obedecendo à legislação e recuperando algumas das funções ambientais da várzea, em núcleos onde a densidade de domicílios e da população é alta e, mais, crescente? É certo que uma solução mais adequada, tanto do ponto de vista ambiental quanto social, no entanto, requereria mais verbas, mais tempo de negociação e de obras, bem como uma retomada da discussão do

\footnotetext{
${ }^{299}$ Semelhante contradição no desenho no traçado do projeto pôde ser observada no projeto do Parque Linear do Ribeirão Perus como destacado no subitem 3.3.
} 
reassentamento das famílias em áreas que hoje perdem população. (TRAVASSOS, 2010, p. 203)

Em sua investigação, Travassos conclui que deve ser uma prioridade para a sociedade a questão da recuperação e preservação ecológica dos rios e várzeas urbanas. A autora, inclusive, relativiza algumas de suas considerações acerca da problemática da habitação. Ou seja, não obstante reconhecer que a questão das condições de moradia da classe trabalhadora é um "gargalo" para a política urbana "sustentável", Travassos enfatiza que mais parques lineares têm que ser feitos nas áreas periféricas da cidade, sem se arriscar a pensar como poderia ser enfrentado o problema crônico da pobreza urbana. O único adendo feito é de que as indenizações para os removidos não podem ser a principal política habitacional, pois implicará em novos problemas socioambientais (ibid., p. 228).

Mesmo desvelando a contradição "social x ambiental", colocada pelo ambientalismo no processo de urbanização, Travassos - assim como outros autores que embasam o "urbanismo verde" -, ao não enfrentar a questão da gênese da desigualdade socioeconômica das cidades incorre no ato de legitimar a expropriação através de um discurso científico. Ao buscar uma solução técnica para um problema que é político, não observa os limites desse tipo de solução. Consequentemente, por não problematizar o movimento de reprodução das relações sociais de produção, fundamenta um processo de intervenção em fundos de vales periféricos que culminam em uma "gentrificação verde", devido às remoções diretas e às indiretas, causadas pela valorização imobiliária e pelo aumento do custo de vida.

Por fim, os recursos públicos para a construção de parques lineares, para a urbanização de favelas e para a implantação das redes de saneamento básico, a partir do olhar aqui exposto, devem ser destinados prioritariamente às áreas mais carentes, onde houve, historicamente, menores investimentos do poder público na transformação do território. Esse parâmetro não se coloca somente por uma questão de justiça social, mas também porque é nessas áreas que esses recursos mudarão de forma mais significativa a qualidade de vida da população. (TRAVASSOS, 2010, p. 228)

É evidente que o urbanismo ambientalista tem importantes princípios de preservação da saúde humana, de recuperação ecológica, mas há que se ter clareza que é também um veiculo de extração de rendas, de expropriação e de exploração. Sem essa noção acaba-se por justapor e confundir ações diferentes - como a implantação de saneamento básico e de parques lineares - como se fossem a mesma coisa. Afirmar que os parques lineares são uma forma de "justiça social" é um contrassenso haja vista a política habitacional que acompanha esses projetos. Trata-se de algo muito distinto de “justiça social”. Logo, há uma enorme simplificação em conceber que a construção 
desse tipo de equipamento por si só contribui para uma maior equidade social.

A "sustentabilidade" como um "novo" paradigma para intervenção urbanística, apesar de apresentar algumas novidades reproduz, sob nova aparência, características do modo de intervenção higienista dos séculos XIX e XX, no que se refere à lida com rios com corpos d’água urbanos e com os trabalhadores, inclusive, a superpopulação relativa. Nesse sentido existe um ocultamento da história por parte da narrativa criada pelo ambientalismo, que não é visto como tributário dessas concepções pretéritas.

\subsection{Urbanismo sanitarista, urbanismo "sustentável" e expropriacão}

Seria o ambientalismo uma extensão do higienismo? Não há uma resposta estanque para essa questão, mas apontamentos sobre semelhanças são possíveis e necessários. Alguns paralelos sobre as duas filosofias já foram realizados nos subitens anteriores. Buscaremos agora arrematar algumas ideias dessa comparação, especialmente no que se refere aos negócios imobiliários e a superpopulação relativa.

Uma das características materiais mais relevantes que nos permite comparar urbanismo sanitarista e urbanismo "sustentável" é o fato de que essas intervenções têm se constituído, na prática, como um meio de lidar com as ocupações de baixa renda. Atualmente, parte dessa população vem tendo sua vida cotidiana pressionada pelas contingências da "sustentabilidade". Assim como no auge do higienismo os problemas derivados da inserção precária de parte da classe trabalhadora nas cidades vem sendo encarado de maneira "técnica" pela ciência e pela administração pública, que os interpreta como um descompasso na relação entre a sociedade e a natureza.

A crescente urbanização da população tem se processado perpetuando a desigualdade social e as ocupações em áreas de proteção ambiental como um dos principais modos de morar da classe trabalhadora o que culmina em riscos individuais e sociais. Os referidos sistemas de interpretação da realidade - higienismo e ambientalismo - lidam com esses riscos apenas em seus sintomas e são incapazes de interpretar suas causas reais. Há uma opção política em ignorar a origem social dos problemas e naturalizá-las: "A medicina social atribuía a desordem urbana às "causas naturais", como ela chama alguns acidentes geográficos, como pântanos e montanhas" (TOMÁS, 1996, p. 19). Nessa perspectiva, o ambientalismo dominante não apresenta grandes novidades. Os termos higienistas atualizam-se e seguem ocultadas as problematizações sobre as reais raízes do enigma urbano: a propriedade privada, a 
desigualdade socioeconômica, os reiterados processos de expropriação, o preço da terra e todos os problemas derivados dessas relações sociais.

Esse fio de continuidade, entre higienismo e ambientalismo, tramado através de distintos processos de reconstrução espacial torna-se uma tessitura se levarmos em consideração o papel dessas ideias no processo de inserção de terras no mercado e nas táticas de valorização imobiliária. Locais que, historicamente, foram habitados pela classe trabalhadora passam a ser vistos, por motivos distintos, como espaços que podem abrigar a expansão da indústria da construção e de outros negócios. As ações higienistas ou ambientalistas se configuram como um instrumento catalizador desse processo, um meio de garantir e elevar o potencial de valorização desses espaços.

Isso pôde ser constatado na região central da cidade de São Paulo, na virada do século XIX para o XX. O relatório de uma comissão higienista encarregada de examinar o problema das doenças no centro de São Paulo, no final do século XIX contem a seguinte passagem ilustrativa: "limpar a área central da cidade, das habitações das classes trabalhadoras, jogá-las para a periferia e reservar a região central, área de terrenos valorizados, para a localização privilegiada do comércio, dos serviços, do sistema bancário e dos escritórios.” (RIBEIRO, M.A.R., 1993, p. 109, apud TOMÁS, 1996, p. 67) Assim, justificou-se a criação de "espaços saudáveis" e a eliminação dos cortiços do centro, retirando os habitantes mais pobres, garantindo, ao mesmo tempo, a redefinição do potencial de extração de renda fundiária. Semelhante fenômeno engendrado de forma mais velada - pode ser observado, no século XXI, em áreas com potencial de se tornar novas centralidades e, que vem recebendo projetos sustentáveis, como nos casos de Itaquera ou Perus. A intervenção do Estado a partir dessas duas filosofias apresenta-se como um instrumento na disputa pelo espaço entre as classes sociais.

À medida que os negócios imobiliários se expandem pela cidade, se deparam, inevitavelmente, com espaços em que a incorporação imobiliária não se dá de forma trivial. Por exemplo, as várzeas de rios. Também os territórios de usos da classe trabalhadora que se configuram como barreiras a dificultar a expansão desse capital (DAMIANI, 2010, p.35). Inicialmente, esses fatos representam um menor potencial de valorização e extração de renda para expansão do capital imobiliário, pois seriam espaços que requerem mais custos para se tornarem incorporáveis ou ainda que, mesmo incorporados, teriam atributos "negativos" na paisagem, que diminuiriam o potencial de renda. Além do mais, a resistência dos trabalhadores em deixar suas moradias atrapalha 
a livre fluidez do capital que busca negócios na cidade. No entanto, essas barreiras não são intransponíveis a esse capital. O Estado cumpre o papel de realizar intervenções de expulsão dos mais pobres, de "embelezamento" do espaço e/ou simples inserção de terras no mercado, garantindo novas áreas de valorização para o segmento imobiliário conforme os impulsos e a direção de expansão desse tipo de capital.

A normatização higienista foi aplicada aonde houve interesses das classes dominantes, Engels já relatava que, na cidade de Manchester do início do século XIX, a vigilância sanitária praticamente não visitava bairros menos centrais da cidade (2010, p. 104). Em São Paulo, no final do século XIX, a proibição dos cortiços se restringiu ao centro da cidade, sendo que em locais mais afastados, essa legislação não se aplicava.

O ambientalismo, à sua maneira, reproduz essa característica, com os parques lineares concentrados em áreas de potencial valorização. Assim, as habitações em fundo de vale são consideradas desordenadas, perigosas ou focos de problemas ambientais, desde que estejam no caminho de potenciais negócios com a cidade. Caso contrário, são toleradas. Portanto, se o consenso higienista apoiou as reestruturações urbanas, nos últimos dois séculos, as ideias ambientalistas, no século XXI, cumprem papel semelhante na "domesticação" de fragmentos do espaço urbano que passam por redefinição funcional.

É possível traçar um paralelo entre a construção do Parque Dom Pedro II e a atual política de parques lineares do município. A Várzea do Carmo, área de enchente do rio Tamanduateí, a partir da explosão demográfica do século XIX para o XX se tornou refúgio da população supérflua - notadamente negros, mestiços e até imigrantes precariamente inseridos na produção. Ocupavam esse fundo de vale, pois era o local possível para a sua sobrevivência naquele cenário de branqueamento e de especulação imobiliária. A visão de progresso dominante, ancorada na eugenia, levou essa várzea a ser estigmatizada como uma área de concentração de pessoas amorais, configurando-se como um problema para o projeto de modernização da cidade.

Na década de 1910, o então Secretário de Justiça e Segurança Pública de São Paulo, Washington Luís ${ }^{300}$, proferiu a seguinte fala sobre a Várzea do Carmo:

É aí que, protegida pelas depressões do terreno, pelas voltas e banquetes do Tamanduateí, pelas arcadas das pontes, pela vegetação das moitas, pela ausência de iluminação se reúne e dorme e se encachoa, à noite, a vasa da cidade, em uma promiscuidade nojosa, composta de negros vagabundos, de negras edemaciadas pela embriaguez habitual, de uma mestiçagem viciosa, de restos inomináveis e vencidos de todas as nacionalidades, em todas as

\footnotetext{
${ }^{300}$ Político que se tornaria presidente da República em 1926
} 
idades, todos perigosos. É aí que se cometem atentados que a decência manda calar; é para aí que se atraem jovens estouvados e velhos concupiscentes para matar e roubar, como nos dão notícia os canais judiciários, com grave dano à moral e para a segurança individual, não obstante a solicitude e a vigilância de nossa polícia. Era aí que, quando a polícia fazia o expurgo da cidade, encontrava a mais farta colheita. (TORRES, 1969, p. 182-183 apud SANTOS, 2001, p. 4)

A elite e a tecnocracia brasileira se viam obrigadas a lidar com contradição capitalista da superpopulação relativa e não escondiam essa visão preconceituosa que legitimava a higienização social. Depois de seguidas ações policiais de "expurgo", de obras de drenagem e retificação desse rio, o Estado planejou o "embelezamento" desse espaço. Para isso, encomendou um projeto paisagístico, concebido segundo o "moderno" padrão estético europeu. O francês Joseph Bouvard projetou, então, o Parque Dom Pedro II, um amplo espaço público, estruturado em alamedas arborizadas concluído em 1922. Através dessa ação, o problema da "amoralidade" dos antigos ocupantes da Várzea do Carmo não foi resolvido, mas pelo menos foi deslocado espacial e temporalmente.

A intervenção sanitarista na Várzea do Carmo nos remete à implantação dos parques lineares por distintas características. A primeira é que ambas as intervenções se dão sobre locais habitados por pessoas de baixa renda - precariamente inseridas no mercado de trabalho - e propõem o "embelezamento" desses espaços, através da criação de um parque público, ornado por projetos de paisagismo. Outra semelhança entre as obras na Várzea do Carmo do início do século XX e as intervenções nas várzeas de córregos na periferia do século XXI é que em ambas as classes sociais mais baixas, usuárias desses espaços, são deslocadas daí e não se planejam propostas de garantia, claras, que essa população possa continuar na cidade.

Higienismo e ambientalismo, cada um à sua maneira, carregam um ideal de progresso e deixam suas marcas em formas espaciais urbanas. No caso do Parque Dom Pedro II, o Estado brasileiro mostrou sua intencionalidade higienista, em uma ação que deslocou e escondeu as contradições sociais do processo de modernização:

No lugar do perigoso e do incontrolável, um parque seguro; do promíscuo, o saudável; do feio, o belo; da sujeira, o asseio e a higiene; da imoralidade, a moralidade; da barbárie, a civilização. No lugar da antiga Várzea freqüentada por incivilizados negros e mestiços, um confortável parque (...) (SANTOS, 2001, p. 5).

Em Perus, o Rodoanel redefine a situação geográfica e as ações ambientalistas complementam a reestruturação imobiliária ao propor o "embelezamento" e enobrecimento para a região. No binômio Rodoanel / preservação ambiental, o segundo 
termo serve para selecionar o tipo de uso do espaço, visto que o primeiro estimula tipos diversos de ocupações. Para o capital é fundamental selecionar o uso do espaço onde a renda fundiária é potencialmente mais alta, indicando em que lugar as ocupações mais pobres são permitidas ou não. Essa prática realizada em associação com o Estado indicando tanto tipos de espaços a serem eliminados como tipos a serem criados perdura desde o urbanismo sanitarista até o "sustentável": parte das ações de domesticação do espaço deve se dar através do embelezamento visual, da criação de espaços de contemplação, limitando as possibilidades de uso.

De certa forma, a medicina social foi veiculo de uma cidadania-bloco capaz de reorganizar a vida e o espaço, transpondo diversos limites (culturais, religiosos, ideológicos etc.) com aval de boa parte da sociedade. De maneira semelhante, o ambientalismo consolidou-se como parâmetro da reorganização dos costumes e do espaço. Somos impelidos a ser "sustentáveis" nos mais distintos gestos da vida cotidiana, ainda que não haja real clareza sobre o sentido dessa ideia. Ou seja, a "sustentabilidade" passa a ser organizadora da vida. No que se refere ao urbano, ela se configura em uma cidadania-bloco, um consenso simbólico necessário à atualização das forças produtivas espaciais. Anteriormente, essa "unanimidade" esteve amparada pelo ideal de "cidade saudável". Atualmente justifica-se pela busca de uma "cidade sustentável"301.

Outra notável continuidade entre a prática dos urbanismos sanitário e "sustentável" é o "empurrar os pobres adiante", para as bordas da cidade, ou para fora dela. Nesse sentido, a viabilização da "cidade sustentável" implica na seleção de moradores que nela habitam. A constante luta por melhores condições de moradia a qual está submetida a classe trabalhadora depara-se com outro meio de espoliação que é o tratamento ambientalista da questão. A combinação entre crise do trabalho $\mathrm{e}$ urbanização como negócio leva certos espaços a serem "ressignificados" para o mercado imobiliário: não faz mais sentido um acumulo de reserva de trabalhadores em espaços que têm potencial para os negócios imobiliários. Como já destacado territórios de uso da classe trabalhadora podem aparecer como "prejudiciais", do ponto de vista da renda fundiária/imobiliária.

${ }^{301}$ Há um descompasso entre o ideal higienista/ambientalista e os limites colocados pelas relações econômicas. Como destacado anteriormente, do ponto de vista ecológico, as ações de recuperação ambiental - como os parques lineares - têm impacto pouco significante perto da expansão e reestruturação urbana capitaneada pelo Rodoanel e projetos associados. O modo reformista de enfrentar a crise ambiental serve para lubrificar o sistema, garantindo sua reprodução. A todo o momento a prática ambientalista institucional apresenta-se como um momento decaído do discurso que difunde. 
Há uma metamorfose da funcionalidade da presença do trabalhador potencial na do morador temporário. A valorização e capitalização das periferias, inclusive reproduzindo formas de especulação financeira e fundiária, constitutivas de centralidades potenciais, acabam por levar a uma acumulação primitiva desses espaços; isto é, uma varredura dos seus usos e moradores existentes, em prol de novas estratégias e empreendimentos. Considerando a imensidão das periferias, as estratégias de expropriação devem ser gigantescas, a exemplo do Rodoanel Mário Covas, em São Paulo, que envolve potencialmente a metrópole inteira. (DAMIANI, 2008, p. 250)

Nesse largo processo de acumulação primitiva do espaço, enfatizamos o fato de o trabalhador potencial - cada vez mais supérfluo - se transfigurar em morador temporário atingido frequentemente pelos projetos urbanísticos que transformam em cenário. Deslocado, ele acaba funcionando como ponta de lança do processo de expansão territorial da metrópole, ocupando novas áreas peri-urbanas ou de preservação ambiental, como destacado no subitem anterior.

No processo de reprodução do espaço urbano é intrínseca à negação periódica e constante de parte da população. Movimento que se realiza com intervenções violentas $^{302}$. Nesse sentido estamos diante de uma conjuntura de "impossibilidade do urbano para todos" e, portanto, de "urbanização crítica" (DAMIANI, 2008; 2010):

O mundo das massas despossuídas é a urbanização crítica. O mundo de uma economia que se realiza criticamente é a urbanização crítica. O urbano como centralidade de culturas, festas, desejos, encontros, necessidades, que é negado, é a urbanização crítica. O mundo do dinheiro, da equivalência, que nos seus fundamentos e subterrâneos, move-se como relações de não equivalência, de exploração do trabalho, de expropriação de meios de vida e de produção, de embate entre as formas do dinheiro - a do dinheiro como medida de valor e como meio de circulação, sintetizadas na forma dinheiro como capital - é a urbanização crítica. A tábua rasa da história, o seu varrer, a produção da obsolescência precoce dos produtos vários, incluindo a cidade, para afirmar novos produtos, é a urbanização crítica. (Idem, 2010, p. 39)

Assim como no sanitarismo, o urbanismo sustentável, distante de uma noção de totalidade, apenas consegue delimitar espaços específicos onde se busca alcançar os objetivos propostos, o que tem como consequência direta o desígnio de "regiões clandestinas" da cidade, aquelas que não estão adequadas às normas. No caso do ambientalismo, desse fato se desdobra um poderoso estereotipo de "pessoas que destroem o meio ambiente em áreas invadidas". Logo, um dos resultados práticos dessa filosofia é a culpabilização - no imaginário social - da população mais pobre, como se esses ocupassem áreas de mananciais ou fundos de vale por uma vontade individual ${ }^{303}$.

\footnotetext{
302 "A violência manifesta-se no quotidiano da classe trabalhadora através da depressão salarial e do acirramento da espoliação urbana” (KOWARICK, 1980, p.187).

${ }^{303}$ Evidentemente há um forte cunho ideológico nessa "culpabilização" que é seletiva e esconde o fato de que as construções de casas de famílias ricas também geram importantes danos ambientais, como destaca MIGLIACCI (2016, p. 69): “A ocupação de tais áreas não é exclusividade da população pobre, lembrando que algumas zonas mais sensíveis, tais como orlas litorâneas, topos de morro, corredores fluviais, privilegiadas do ponto de vista ecológico, também são cobiçadas pela urbanização de alto poder
} 
De forma veemente Rizzi (2011b) descreve o processo de higienização social contido na prática e ideologia de "sustentabilidade" urbana.

O racismo nas palavras desses planejadores é a intervenção agindo para multiplicar os riscos: se de um lado faz pouco contra, ou mesmo facilita a especulação imobiliária, de outro, caça com vigor os "criminosos ambientais". É a sombria relação entre riscos naturais e pobreza urbana, o motor deflagrador do crime ambiental, a mais nova modalidade subversiva dos mais pobres. (RIZZI, 2011b, p. 139)

No auge do higienismo, o seu sentido moralista levava os cidadãos "improdutivos" a serem perseguidos e retirados do espaço urbano "produtivo". Por mais que a filosofia "verde" não explicite verbalmente moralismo e classismo, sua prática o faz $^{304}$. Analisado o atual contexto, é possível pensar que o processo de perseguição e isolamento da população supérflua ganha outra escala em um momento de urbanização crítica - mesmo não sendo uma perseguição assumida, como fora em outros tempos. Nota-se essa nova escala através de distintos processos como por exemplo: a política de remoções; o encarceramento em massa ${ }^{305}$; o genocídio da população negra e periférica $^{306}$; o confinamento nos bairros periféricos pela ausência e pelo preço do transporte público; na repressão aos momentos de festa e encontros nas periferias etc. ${ }^{307}$

Para melhor compreender o atual processo que para o qual está subjugada a classe trabalhadora é necessário, mais uma vez, voltarmos às teorias que estavam sendo desenvolvidas na aurora da sociedade urbano industrial a fim de buscarmos as continuidades. Nessa época, além das ideias higienistas, também ganharam seguidores as teorias de Thomas Malthus sobre população - que, por sinal, reverberam até os dias de hoje. Esse autor via o crescimento populacional como uma ameaça à sociedade em geral, pois a produção dos meios de subsistência - supostamente - não seria suficiente para acompanhar o acelerado incremento demográfico ${ }^{308}$. Assim, esse autor formulou a

aquisitivo, provocando igualmente graves danos socioambientais, tais como erosão do solo, assoreamento de cursos d'água, supressão da vegetação nativa, entre outros".

${ }^{304}$ Em alguns casos esse caráter escapa do nível da ideologia e se torna explícito como no caso do "Memorando Summers", descrito no capítulo 2.

305 Segundo o Ministério da Justiça e Segurança Pública - Departamento Penitenciário Nacional (2017), no Brasil, entre 1990 e 2016, a população carcerária cresceu mais de 8 vezes, passando 90 mil para 726 mil.

${ }^{306}$ Para mais informações sobre o tema ver Adão, 2017.

${ }^{307} \mathrm{Em}$ outro contexto histórico, Kowarick (1980, p. 59), descreveu um processo semelhante de recrudescimento da luta de classes: "Nesse aspecto, quando os recursos estatais se canalizam preponderantemente para imperativos da acumulação de capital em detrimento daqueles mais diretamente acoplados à reprodução da força de trabalho, acirrando o processo de espoliação urbana, e quando a criação de excedente se realiza também através da pauperização absoluta de vastos contingentes sociais, o Estado, para viabilizar semelhante "modelo de ordem social" de características selvagens para a força de trabalho, só pode assumir feições nitidamente autoritárias e repressoras".

308 Apesar de as ideias de Malthus ainda viverem, sua teoria já foi amplamente refutada, o que o levou a ser classificado com um ideólogo da economia burguesa. Malthus desconsiderou a capacidade produtiva 
ideia de que o "pauperismo" seria saudável para a sociedade, pois a miséria serviria para reequilibrar a desproporção entre a multiplicação humana e a dos meios de subsistência. “A miséria para Malthus, é, portanto, necessária. Ela aparece na fome, no desemprego, no rebaixamento dos salários; então, ela mata, ela faz adoecer, ela reduz o número de matrimônios, pois será mais difícil sustentar os filhos (...)”. (DAMIANI, 2011, p. 14)

O pauperismo como forma de controle populacional dos trabalhadores urbanos foi observado por Engels (2010), no século XIX, que viu a teoria de Malthus realizando-se na prática.

Muito mais numerosas foram as mortes causadas indiretamente pela fome, porque a sistemática falta de alimentação provoca doenças mortais: as vitimas viam-se tão enfraquecidas que enfermidades que, em outras circunstancias, poderiam evoluir favoravelmente, nesses casos determinaram a gravidade que levou à morte. A isso chamam os operários ingleses de assassinato social e acusam a sociedade de praticá-lo continuamente. Estariam errados? (Ibid. p.69, destaque do autor)

$\mathrm{Na}$ teoria malthusiana está implícito que a divisão social em classes economicamente desiguais é resultado de uma seleção de seres humanos superiores, mais aptos, o que justificaria a situação de dominância dessas classes. Sua consequência seria a penúria e morte dos mais pobres, o que, segundo essa teoria, seria saudável para a sociedade como um todo. Para Malthus, a sociedade não deveria dispender sua riqueza social para atender às necessidades das classes mais pobres (garantindo-lhes, por exemplo, alimentação, moradia, educação, saúde etc.). Esse seria um investimento improdutivo, um desperdício, realizado em detrimento de outras destinações que essa riqueza poderia ter, como por exemplo, o investimento na produção de mercadorias.

Deixar morrer, por omissão, essa seria a base malthusiana do assassinato social. Observamos, historicamente, que o controle demográfico dos explorados não se deu através da gerência da natalidade, como sugeriu Os limites do crescimento (1972). A gestão populacional ocorreu através dos níveis "saudáveis" de fome, doença e morte, justificados pela tecnocracia que impõe a "racionalidade econômica" à sociedade, inclusive, quantificando qual vida vale mais que a outra, como deixaram transparecer Meddows et al., 1972.

crescente da sociedade, refugiando-se em uma relação numérica abstrata, de modo a colaborar com a perpetuação da miséria (DAMIANI, 2011). A quantidade de comida disponível é indiferente ao trabalhador se esse não tem uma ocupação remunerada e não pode adquiri-la "portanto, são os meios de emprego e não os de subsistência que colocam o trabalhador na categoria de população excedente, miserável, ou não" (ibid.). O desenvolvimento das forças produtivas chegou a tal ponto que há mais meios de subsistência do que o que seria necessário para abastecer toda a população mundial, entretanto a miséria prossegue e, se agrava. O malthusianismo não explica a simultânea superprodução de alimentos e a propagação da fome, no entanto a ideologia neomalthusiana persiste e pauta estratégias políticas reais e eficazes. 
A omissão da sociedade - sobretudo, na figura do Estado que, supostamente, preza pelo bem comum - frente à morte generalizada é complementada por reiterados processos de expropriação, que contribuem para o assassinato social tornar-se mais efetivo. Observamos medidas que envolvem remoções e não apresentam soluções para a questão da moradia, o que é justificado, frequentemente, pela falta de verba necessária para tal. Nesse quesito, tanto higienismo quanto o ambientalismo, são tributários do malthusianismo, na medida em que se recusam a investir a riqueza social para fins considerados "improdutivos" - como moradias adequadas para as pessoas de baixa renda. Tratando especificamente da política ambientalista em implementação em São Paulo, é possível afirmar que dela se desdobra o aumento da pobreza, o que seria, para Malthus, "sadio" para a sociedade. Segundo Damiani (2010, p. 40) "A realidade urbana se tornou malthusiana".

Como já ressaltado, no capítulo 2, o ambientalismo flertou abertamente com o neomalthusianismo em Os Limites do Crescimento e, posteriormente, o fez de forma velada. $\mathrm{O}$ fato é que os limites do crescimento da economia capitalista apontavam para um cenário de crescimento da superpopulação relativa e o ambientalismo acabou tornando-se um discurso legitimador da implementação de medidas neoliberais (e malthusianas), através de uma "roupagem" mais aceitável para a população.

Esse neomalthusianismo que desembocou no discurso de sustentabilidade acabou transmutando-se em políticas que fazem operar o malthusianismo clássico, aquele do "deixar morrer", do aumento da desigualdade social "saudável".

Em um contexto em que o desemprego estrutural se expande, assim como os negócios imobiliários, a cidade se torna cada vez mais um cenário, no qual a crescente população supérflua não tem lugar, ou o tem, permanentemente, de forma transitória e sob risco de expropriação.

Portanto é notável que o pensamento higienista ressurja com potência nas políticas urbanas. Às vezes de forma direta, sem nova roupagem, como no caso das ações de higienização da "cracolândia". Outras vezes, sob nova aparência, como "sustentabilidade" urbana. 


\section{Consideracões Finais:}

Quando essa pesquisa começou a ser realizada havia indícios de avanços de práticas de higienização na reprodução da sociedade, sendo cada vez mais "permanente o estado de exceção", representado entre outras formas, através de um projeto de cidade sustentável, que, veladamente, expulsa milhares de pessoas de suas casas, desrespeitando direitos conquistados. Observamos, no final desse ciclo da dissertação, um acirramento da crise econômica e da dominação de classe, o que nos leva a pensar que, em um futuro próximo, situações de exceção podem ser menos veladas e mais sistemáticas.

A reprodução "cega" do capital, na sua versão financeira imobiliária, é dirigida pela - reificada e, portanto, turva - visão dos tecnocratas do espaço e do mercado financeiro. A percepção fetichista de que se está preparando o "desenvolvimento" ou de que se está reproduzindo D-D' (dinheiro que vira mais dinheiro) tem, como base real, processos de expropriação $\left(\right.$ roubo $^{309}$ ), tendo em vista que é necessário mobilizar a propriedade territorial para haver valorização imobiliária e aumento do lastro de circulação de capital financeiro e fictício.

Vimos, ao longo do texto, que na reificada contabilidade da sociedade produtora de mercadorias, a vida de parte da classe trabalhadora pode ser considerada "descartável", podendo ser abreviada ou deslocada, caso isso signifique uma oportunidade de aumento de rentabilidade para os capitais.

Intensifica-se a automação da sociedade, em que os objetos tornam-se os sujeitos. Dessa maneira, os tecnocratas que, por vezes, creem que estão no comando das ações, na verdade, cumprem papel central de títeres do capital financeiro imobiliário e acabam personificando instrumentos na disputa entre as classes sociais pelo espaço.

Os gravíssimos problemas que envolvem a sociedade e seu ambiente devem ser compreendidos através da luta de classes. A despeito de seu potencial contestador dos fundamentos da sociedade capitalista, o ambientalismo - da forma como constituiu sua face dominante - se caracteriza por uma crítica social rasa ou ausente. Ignora os fundamentos da reprodução social e do processo de modernização, ignora a História e a desigualdade social como algo estruturante da sociedade. Assim, oculta as contradições

\footnotetext{
309 Como costuma dizer Andreia, moradora de Perus: “expropriação é uma palavra bonita que vocês usam, o nome disso é roubo mesmo!"’.
} 
entre as classes sociais e afirma o conflito sociedade e natureza ${ }^{310}$. Dessa forma constitui-se como um elemento desorientador da compreensão do mundo, um pseudoconceito, uma "ideologia", a filosofia "verde".

Dessa maneira, afirma-se como um ambientalismo de classe, cuja característica marcante é a própria espetacularização. Evidentemente que a decomposição dessa manifestação não se deu sem oposição por parte de um ecologismo contestador das relações sociais. A entrada da questão ambientalista no debate público brasileiro, por exemplo, ocorreu, na década de 1980, pela via das lutas dos seringueiros da Amazônia, liderados por Chico Mendes. É importante ressaltar que essa era uma disputa vinculada à reivindicação sindical e revolucionária dos trabalhadores rurais, que obtinham, através da preservação da floresta em pé, tanto um meio de produzir (e subsistir) como uma via de busca pela sua emancipação. Não era, portanto, uma luta pela natureza autonomizada e decorativa. Era uma forma de ser da luta de classes. A concepção de natureza que envolvia as movimentações dos seringueiros incluía o ser humano e as relações sociais, inclusive, tinha como base a utopia da transformação social.

O ambientalismo, que incorpora pautas da classe trabalhadora carrega um potencial revolucionário. Não é à toa que - assim como ocorreu com Chico Mendes tem sido constantes a perseguição e o assassinato de lideranças ambientalistas, quilombolas, indígenas, sindicais etc. Trata-se de um processo contínuo dessa sociedade que se reivindica cada dia mais "sustentável", ao passo que reprime a possibilidade de constituição de um ambientalismo que questione as relações sociais de produção.

É necessário, portanto, não naturalizar a "sustentabilidade", tendo em conta que ela é fruto de conexões entre o saber, a economia e a política, sendo assim, carregadas de interesses de classes específicas. Em poucas palavras, o ambientalismo dominante expresso pela máxima de “desenvolvimento sustentável" - é uma ideologia conservadora e neoliberal.

Essa afirmação é possível tomando como base a nossa análise sobre o urbanismo "sustentável” aplicado no município de São Paulo, veículo de um processo de “gentrificação verde" e culpabilização dos mais pobres pelos problemas urbanos ${ }^{311}$.

\footnotetext{
310 "O que as premissas do ambientalismo negligenciam é a compreensão da natureza social do mundo" (SEABRA, 2013, p.9).

$311 \mathrm{Na}$ verdade trata-se do contrário, os trabalhadores são a principais vítimas dos problemas que são gerados pelo capital. Como ressaltou KOWARICK (1980, p.53): "As coisas simples precisam constantemente diretas: é o capital - e não a sua força de trabalho - que deteriora a vida metropolitana".
} 
Nesse sentido, Smith propõe uma maior politização do debate sobre a natureza: "Na medida em que a natureza é mais intensamente integrada ao capital como estratégia de acumulação, a abrangência desta produção social da natureza sob o capitalismo se torna cada vez mais aparente, e a necessidade de uma ampla resposta política mais urgente" (2006, p. 34, tradução nossa). A nosso ver, o trajeto para essa resposta passa por uma inadiável superação do ambientalismo "burguêsespetacularizado-sustentável" e pelo fortalecimento de um pensamento em que a questão ambiental não seja autonomizada e esteja ancorada nas necessidades reais de melhoria das condições de vida da classe trabalhadora e na sua emancipação.

Voltemos ao caso específico da zona noroeste, para observar como a "sustentabilidade" burguesa é um instrumento de classe. Dada a regulação orçamentária que limita o uso do dinheiro dos créditos de carbono para políticas ligadas ao "meio ambiente" na região noroeste, haveria alguma destinação mais coerente para essa verba do que em ações que beneficiassem a população Guarani Mbya do Jaraguá? Esses - que a despeito da condição de penúria a que estão submetidos, são grandes responsáveis pela existência de uma importante área vegetada em plena metrópole - não mereceriam parte desse recurso público destinado à preservação do meio ambiente? Ocorre que os interesses dominantes caminham no sentido oposto da manutenção desse território indígena. E ações afirmativas desse povo iriam contra a "sustentabilidade" dos negócios previstos para essa região. Esse é mais um exemplo de como o ambientalismo pode ser manipulado para ocultar contradições sociais, enquanto legitima a violência do processo econômico.

Nossa hipótese é que faz parte do objetivo das ações "sustentáveis" se realizar enquanto representação que, supostamente, questiona o status quo e fazer disso uma publicidade, ao passo que, ao mesmo tempo, essa ideologia se sobrepuja perante outros debates contestatórios em voga, como a questão indígena ou o direito à cidade, por exemplo.

A catástrofe ambiental surge a partir do processo "cego" do capitalismo. Então, em um momento seguinte, ela é constatada, organizada (na aparência) e gerida pelo capital. Por mais que não se trate de evitar catástrofes, como já assinalava Debord, a preservação ecológica se torna importante para a humanidade. "É tentador parafrasear a avaliação de Engels da 'questão da habitação': a burguesia não tem solução para o problema ambiental, ela simplesmente o move ao redor" (SMITH, 2006, p.20, tradução nossa). A importância dada à ecologia mostra-se impotente diante das crescentes 
adversidades socioambientais, contudo torna-se útil ideologicamente, para os negócios.

A colonização do tempo livre através da mercantilização da sensação de "volta à natureza" se tornou uma indústria, por meio do ecoturismo realizado nas férias e finais de semana. O urbanismo "sustentável” busca expandir essa sensação para o dia-a-dia da cidade por meio da criação de espaços de contemplação para produtos imobiliários em bairros "verdes", viabilizando o consumo de um espaço livre de "poluição estética". O planejamento "sustentável" propõe a produção de um espaço cenário, agradável à visualização, no qual, preferencialmente, está ausente a fração mais pobre da classe trabalhadora.

Assim sendo, a pasteurização da ecologia revela-se uma oportunidade de "desenvolvimento" econômico para regiões "onde o progresso não chegou", visto que essas podem comportar maior profusão de áreas "verdes" (SANTANA, 1999). O desenvolvimento desigual produziu espaços tidos como "atrasados" que podem se revelar como rentáveis matérias primas para a indústria do ecoturismo. Também a indústria imobiliária busca se aproveitar dessa condição. O processo de reestruturação imobiliária de Perus é um exemplo disto, uma vez que existe um projeto de conversão de espaços rurais e de moradia da classe trabalhadora em locais "sustentáveis".

Evidentemente que o complexo financeiro-imobiliário - que, como vimos, envolve o Estado - trata de afastar o signo periférico ou operário de Perus, na medida em que afirma o emblema "verde". Nesse sentido O investimento de créditos de carbono em "projetos urbanísticos sustentáveis" foi um trunfo, ao buscar garantir outra especificidade para Perus na concorrência entre os lugares pelo capital fictício, buscando demonstrar que esse local está habilitado para construir espaços capazes de extrair renda, não só pela situação logística, mas também pela peculiaridade de sua preservação ambiental.

Esse fato compõe um amplo processo de reestruturação imobiliária, marcado pela reprodução do capital via produção do espaço que alcança áreas historicamente suburbanas e/ou periféricas através de processos mais intensivos de valorização imobiliária.

Há muitas décadas que as características fundiárias da região noroeste indicam a virtualidade de um avanço da fronteira urbana. Contudo, a possibilidade de alcançar o potencial de valorização dependia de intervenções do Estado em prol da reestruturação, que ressignificassem o valor de uso do solo e atraíssem capitais privados. A construção do Rodoanel, segundo nossa hipótese, foi a ação fundamental para re-situar essas 
propriedades territoriais na metrópole, aumentando sua capacidade de extração de renda e, consequentemente, a sua potencialidade de metamorfose em capital.

Apesar de rearranjar a escala dos negócios, a redefinição da situação geográfica através do Rodoanel, por si só, não cumpre completamente o papel de domesticar o espaço de maneira adequada a receber capitais em busca de valorização imobiliária a partir de diferentes produtos. Isso porque, na região noroeste, a reestruturação imobiliária atingiu um "subúrbio-periferia", situado além do cordão sanitário, local onde historicamente se "escondiam" algumas das mazelas da "cidade saudável": uma fábrica que emitia poluentes; os depósitos de resíduos (“lixões”); um hospital de isolamento; um cemitério de indigentes; uma vala de vítimas da ditadura; diversas moradias das frações mais pobres da classe trabalhadora...

A avidez do capital por mobilizar terras para negócios imobiliários conflui para que esse espaço seja inserido para dentro do cordão sanitário, ou melhor, "sustentável", de modo a ser incorporado, mais intensamente, à lógica de valorização. Assim, se estivéssemos no início do século XX e a região noroeste entrasse no eixo de valorização do capital, provavelmente, estariam sendo discutidos projetos sanitaristas para Perus, a fim de eliminar as práticas e usos do espaço não desejáveis. No entanto, é através do ambientalismo que o Estado busca domesticar esse espaço, tornando-o mais homogêneo, consumível, adequado às “vontades” do capital financeiro imobiliário.

Evidentemente, que nesse processo de transformação se realiza o "expurgo" (como diria Washington Luís) de parte da população desse local. Na medida em que as condições de habitabilidade vão se tornando melhores, uma parcela das pessoas que viveram durante décadas os infortúnios do desenvolvimento geográfico desigual em Perus devem ser impelidas a se retirar. Constata-se que, na cidade como negócio, os corpos e as mentes da classe trabalhadora estão constantemente sujeitos a experiências traumáticas, relacionadas a processos de expropriação de vários níveis, tais como: expulsão forçada de sua casa, impossibilidade de pagar o aluguel, destruição de espaços de representação, entre outras formas relatadas ao longo dessa dissertação.

Por fim, é preciso esclarecer que o esquema analítico aqui proposto para a reestruturação imobiliária de Perus é uma tentativa de aproximação do movimento do real, que comporta sobreposições e contradições no que tratamos como a passagem de um bairro operário para um "bairro periférico-dormitório" e, então, para uma nova centralidade logístico-sustentável, sendo esse último estágio ainda mais potencial do que real. Afirmamos que o momento presente comporta, simultaneamente, essas três 
temporalidades: 1- fragmentos do bairro implodido; 2- condições de vida típicas da periferia metropolitana 3- indícios e promessas de novos negócios imobiliários.

Não é possível cravar que essa última transição será completada materialmente. Nota-se que ela se reproduz por impulsos não contínuos. A inauguração do Rodoanel Oeste, no começo dos anos 2000, foi um impulso. O auge do ciclo de commodities, no fim da década passada, foi outro, quando vários projetos imobiliários (públicos e privados) estavam em andamento ao mesmo tempo. Medidas anticíclicas, como o MCMV, fizeram esse momento ainda perdurar mais alguns anos. E, claro, a injeção de investimentos públicos através da venda de créditos de carbono foi outro estímulo, que teve seu ritmo quebrado com a crise financeira internacional de 2008. Desse arranque resultam algumas obras em andamento, outras paradas e, muitos projetos preparados, à espera de um próximo impulso econômico.

O caráter potencial da reestruturação imobiliária de Perus nos leva a crer que a violência da expropriação ainda não foi inteiramente realizada e que uma nova rodada de mobilização de terras e espoliação pode estar por vir. 


\section{Referências bibliográficas:}

ADÃO, C.R. Territórios de morte: homicídio, raça e vulnerabilidade social na cidade de São Paulo. Dissertação de Mestrado (em Mudança Social e Participação Política) - ECAUSP, São Paulo, 2017.

ANDRADE, C.R.M. A Peste e o Plano. O Urbanismo Sanitarista do Engenheiro Saturnino de Brito, dissertação de mestrado, vol.I, FAU/ USP, 1992.

. “Putrid Miasmata': higienismo e engenharia sanitária no século XIX.” In:

Cadernos de Arquitetura. Ano 1, n.2 Bauru : FAAC, UNESP, 1996.

ALVAREZ, I.A.P. “A segregação como conteúdo da produção do espaço urbano”. In: VASCONCELOS, P. A.; CÔRREA, R.L.; PINTAUDI. S. M.. (Org.). A cidade contemporânea. Segregação espacial. $1^{\mathrm{a}}$ ed. São Paulo: Editora Contexto, 2013, v. , p. 111-126.

.A plasticidade da metrópole de São Paulo: reprodução do espaço, financeirização e propriedade da terra.” Revista Cidades, v.11, n¹9, 2014.

BENACH, N. Perspectivas culturais para o estudo da cidade. In: CARLOS, A. F. A.; CARRERAS, C. (Orgs.). Urbanização e mundialização: estudos sobre a metrópole. $1 .{ }^{\mathrm{a}}$ ed. São Paulo: Contexto, v. 1, p. 70-80, 2004.

BEZERRA, P.A.B. A reprodução do espaço urbano na periferia da metrópole e o discurso da sustentabilidade como estratégia de valorização: uma análise crítica do projeto Parque Linear Ribeirão Perus. Dissertação de Mestrado (Mestrado em Geografia Humana) - FFLCH-USP, São Paulo, 2017.

BIDERMAN, C., MEYER, R.M.P., GROSTEIN, M. D. São Paulo Metrópole. São Paulo: Edusp, 2004.

BOTELHO, A. Do fordismo à produção flexível: a produção do espaço num contexto de mudança das estratégias de acumulação do capital. Dissertação de Mestrado (Mestrado em Geografia Humana) - FFLCH-USP, São Paulo, 2000.

. Uma trajetória do mercado imobiliário em São Paulo (1554 - 2004). In: CARLOS, A.F.A.; OLIVEIRA, A.U. Geografias das Metrópoles. São Paulo: Contexto, pp. $231-251,2006$.

- A renda fundiária urbana: uma categoria de análise ainda válida. Revista GEOgraphia (UFF), v. 19, p. 23-40, 2008.

BRASIL ARQUITETURA. Programa de urbanização de favelas Comunidade do Bamburral. Julho/2011.

BONDUKI, N. G. Origens da Habitação social no Brasil - Arquitetura moderna, Lei do 
Inquilinato e Difusão da Casa Própria. São Paulo: Estação Liberdade, 2001.

BOURDIEU, P. Distinction: A Social Critique of the Judgement of Taste, Londres, Routledge \& Kegan Paul, 1984.

CABANIS, P.J.G. Textes, Louis Michaud Éditeur, Paris, s/d.

CARLOS, A. F. A. “A reprodução da cidade como negócio". In: CARLOS, A. F. A.; CARRERAS, C.. (Org.). Urbanização e Mundialização. Estudos sobre a metrópole. São Paulo: Editora Contexto, 2004, p. 29-37.

CARNEIRO, C.D.R. Análise estrutural do Grupo São Roque na faixa entre o Pico do Jaraguá e a Serra dos Cristais, SP. Tese de Doutoramento apresentada a I.G.-USP, São Paulo, 1983.

CHESNAIS, F. A mundialização do capital. São Paulo: Xamã, 1998.

CMMAD (COMISSÃO MUNDIAL SOBRE MEIO AMBIENTE E DESENVOLVIMENTO). Nosso futuro comum. Rio de Janeiro: Fundação Getulio Vargas, 1988.

CONEJERO, M. A. Marketing de Créditos de Carbono: Um estudo exploratório. Dissertação de Mestrado, Pós-Graduação em Administração de Organizações do Departamento de Administração da Faculdade de Economia, Administração e Contabiliade de Ribeirão Preto, 2006

CONFEMA (Conselho do Fundo Especial do Meio Ambiente). Ata da 32ª Reunião Plenária Ordinária do Confema, out. 2008. Disponível em: < http://www.prefeitura.sp.gov.br/cidade/secretarias/upload/chamadas/ata_32_ro_confem a_1340208170.pdf > Acessado em 09 abr. 2014.

Ata da 49 Reunião Plenária Ordinária do Confema, 02 de fev. 2010a < https://www.prefeitura.sp.gov.br/cidade/secretarias/upload/chamadas/rel_atividades_co nfema_2010_1305131344.pdf > acessados em 17 de setembro de 2017.

- Ata 54 Reunião Plenária Ordinária do Confema, jun. 2010b < https://www.prefeitura.sp.gov.br/cidade/secretarias/upload/chamadas/ATA_ordinaria_5 4_1278438710.pdf > e

. Ata da 70ª Reunião Plenária Ordinária do Confema, set. 2012. Disponível em: <http://www.prefeitura.sp.gov.br/cidade/secretarias/upload/chamadas/ata_da_70_reunia o_ordinaria_confema_18_de_setembro_de_2012_-_helena_1356014560.pdf> Acessado em 05 abr. 2014. 
CORNETTA, A. A financeirização do clima: uma abordagem geográfica do mercado de carbono e suas escalas de operação. Dissertação de Mestrado (Mestrado em Geografia Humana) - FFLCH-USP, São Paulo, 2013.

- Entre o clima e a terra: uma análise geográfica da "economia de baixo carbono" na Amazônia Legal. Tese de Doutorado (Doutorado em Geografia Humana) FFLCH-USP, São Paulo, 2017.

DAMIANI, A. L. Espaço e Geografia: Observações de Método - Elementos da obra de Henri Lefebvre e a Geografia; - Ensaio sobre Geografia Urbana a partir da Metrópole de São Paulo. Tese de livre docência, FFLCH-USP, São Paulo, 2008. . Urbanização crítica e produção do espaço. In: Revista Cidades, volume 6, no 10, 2009. p. $307-339$. . "Urbanização crítica e situação geográfica". In: CARLOS, A. F.; OLIVEIRA, A. U. (Orgs.). Geografias de São Paulo: representação e crise da Metrópole. São Paulo, Contexto, pp. 19-54, 2010. . População e Geografia. 9a ed. São Paulo: Contexto, 2011. . A produção do espaço urbano e a propriedade privada da terra. Revista Continentes (UFRRJ), ano 5, nº 9, pp. 24-36, 2016.

DEBORD, G. A sociedade do espetáculo. Rio de Janeiro: Contraponto, 1997.

. O planeta doente. 2015. Disponível em < https://arlindenor.com/2015/04/24/oplaneta-doente-2/ > Acessado em 11 de outubro de 2017.

EL KHALILI, A. 2017 Disponível em < http://operamundi.uol.com.br/dialogosdosul/creditosde-carbono-para-quem/19082017/ > acessado em 10 de fevereiro de 2018.

ENGELS, F. A situação da classe trabalhadora na Inglaterra. São Paulo: Boitempo, 2010.

FARIA, C.S. A luta Guarani pela terra na metrópole paulistana: contradições entre a propriedade privada capitalista e a apropriação indígena. Tese de Doutoramento em Geografia Humana apresentada a FFLCH-USP, São Paulo, 2016.

FARIA, L. Valoração ambiental e pagamento por serviços ecossistêmicos na economia financeirizada. Coletânea de artigos do Seminário Perspectivas de Natureza. [S.I.]: 2017. Não publicado.

FURLAN, S. A. Florestas culturais: manejo sociocultural, territorialidades e sustentabilidade. In: Agrária. São Paulo, N³, pp. 3-15, 2006.

GAUDEMAR, Jean Paul de. Mobilidade do trabalho e acumulação de capital. Lisboa: Estampa, 1977.

GEORGE, Pierre. O Meio Ambiente. São Paulo: Difusão Européia do Livro, 1973. 
Geografia Urbana. São Paulo: Difel, 1983.

GONÇALVES, G. R. A produção espetacular do espaço: As cidades como cenário na Copa do Mundo de 2014. Relatório de qualificação de Doutoramento em Geografia Humana apresentada a FFLCH-USP, São Paulo, 2013. Trabalho não publicado.

A produção espetacular do espaço: As cidades como cenário na Copa do Mundo de 2014. Tese de Doutoramento em Geografia Humana apresentada a FFLCHUSP, São Paulo, 2015.

HARVEY, D. Los limites del capitalismo y la teoria marxista. México: Fondo de Cultura Economica, 1990. . O enigma do capital: e as crises do capitalismo. São Paulo: Boitempo, 2011 . Cidades Rebeldes, São Paulo, Martins Fontes, 2012. . Condição pós-moderna. 25a Ed. Rio de janeiro: Edições Loyola, 2014. . Paris, capital da modernidade. São Paulo: Boitempo, 2015.

JACQUES, P. B. Apologia da Deriva. Escritos situacionistas sobre a cidade. Rio de Janeiro: Casa da Palavra, 2003.

JESUS, M.C. "Vinte e dois anos de luta sindical na Perus". In: JESUS, M.C. (Org). Cimento Perus: quarenta anos de ação sindical transformando velha fábrica em centro de cultura municipal. São Paulo: JMJ, pp.25-73, 1992.

JESUS, M.C; NOBRE, A.; CRUZ,S.F; AZEVEDO C.S.. "A última greve, em 1986, e o fechamento da fábrica”. In: JESUS, M.C. (Org). Cimento Perus: quarenta anos de ação sindical transformando velha fábrica em centro de cultura municipal. São Paulo: JMJ, pp. 74-81, 1992.

KOWARICK, L. A espoliação urbana. Rio de Janeiro: Paz e Terra, 1980.

KURZ, R. O Colapso da Modernização: "Da derrocada do socialismo de caserna à crise da economia mundial”. Rio de Janeiro: Paz e Terra, 1992.

A bolha do imobiliário (2005). Disponível em: $<$ http://obeco.planetaclix.pt/rkurz200.htm> Acessado em: 12 de maio de 2012.

LANGENBUCH, J. R. A estruturação da Grande São Paulo: estudo de Geografia urbana. Rio Janeiro: IBGE, 1971.

LEFEBVRE, H. Introdução à modernidade. Rio de Janeiro: Paz e Terra, 1969. . A Produção do espaço. Tradução Grupo “As (im)possibilidades do urbano na metrópole contemporânea", do Núcleo de Geografia Urbana da UFMG (do original: La production de l'espace. $4^{\mathrm{e}}$ éd. Paris: Éditions Anthropos, 2000). Primeira versão: início - fev. 2006 (Trabalho não publicado). 
Espaço e Política. Belo Horizonte: Editora UFMG, 2008a.

. O Direito à Cidade. 5. ${ }^{\mathrm{a}}$ ed. São Paulo: Centauro, 2008b.

A Revolução Urbana. Belo Horizonte: Editora UFMG, 2008c.

LUKÁCS, G. História e Consciência de Classe - Estudos sobre a dialética marxista. São Paulo: Martins Fontes, 2003

MARICATO, E. Nunca fomos tão participativos. O impasse da política urbana no Brasil. Petrópolis: Vozes, 2011.

MARTINS, B. X. O Programa Minha Casa Minha Vida: a mercadoria habitação a serviço da reprodução do capital em contexto de crise. Dissertação de mestrado (Mestrado em Geografia Humana) - FFLCH-USP,, São Paulo, 2016.

MARX, K. O Capital. Livro I. São Paulo: Nova Cultural, 2ª ed., 1985.

. O Capital. Livro III. São Paulo: Boitempo, 2017.

MEADOWS, D; MEADOWS, D; RANDERS, J; BEHRENS III, W. The Limits to Growth. New York: Universe Books, 1972.

MIGLIACCI, M.C.W.R. Os parques lineares na dinâmica da produção do espaço urbano na periferia - o caso do Parque Linear do Córrego Do Rio Verde em Itaquera - São Paulo. Dissertação de Mestrado (Mestrado em Geografia Humana) - FFLCH-USP, São Paulo, 2016.

MISKOLCI, R. A hora da eugenia: raça, gênero e nação na América Latina. Cad. Saúde Pública vol.22 no.1 Rio de Janeiro Jan. 2006. Disponível em < http://www.scielo.br/scielo.php?script=sci_arttext\&pid=S0102-311X2006000100028 > Acessado em: 01 de outubro de 2018.

MINISTÉRIO DA JUSTIÇA E SEGURANÇA PÚBLICA - Departamento Penitenciário Nacional. Levantamento Nacional de Informações Penitenciárias Atualização - Junho de 2016. Brasília, 2017.

MORENO, C.; FUHR, L.; CHASSÉ, D.S. Para além da métrica do carbono. Project Syndicate. Berlim, 29 de março de 2016. Disponível em <https://www.projectsyndicate.org/commentary/climate-change-alternative-approaches-by-camila-morenoet-al-2016-03/portuguese> , Acessado em 12 de fev. de 2017.

OLIVEIRA, F. Critica à razão dualista/O ornitorrinco. Editora Boitempo, São Paulo, 2003.

PELLEGRINI, A. L. T. A. Trabalho, moradia, saúde e cultura: entrelaçando relações: uma experiência em pesquisa-ação a partir do PSF Recanto dos Humildes, Perus. Dissertação de Mestrado, Universidade Federal de São Paulo, 2011.

PEREIRA, P.C.X. A reestruturação imobiliária em São Paulo como chave para o 
desvendamento da metrópole atual. IN: CARLOS, A. F. A. e OLIVEIRA, A. U. (orgs.). Geografias das metrópoles. São Paulo: Contexto, 2006, p. 219-230.

PL 0331/2011, Projeto de Lei apresentando à Câmara Municipal de São Paulo. Plano de

Bairro do Distrito de Perus. Lei complementar ao Plano Diretor Estratégico do Município de São Paulo.

PORTO-GONÇALVES, C. W. P. "Paixão da Terra" Ensaios Críticos de Ecologia e Geografia. Rio de Janeiro: Ed.Rocco, 1984.

. Os (des)caminhos do meio ambiente. $5^{\text {a }}$ ed., São Paulo: Contexto, 1996. - A globalização da natureza e a natureza da globalização. $5^{\mathrm{a}}$ ed., Rio de Janeiro: Civilização Brasileira, 2013.

RIBEIRO, M. A. R. História Sem Fim..., Ed. UNESP, São Paulo, 1993.

RIBEIRO, W. C.; EVASO, A. S.; JUNIOR, C. B.; VITIELlO M. A.; NOGUEIRA, S. M. “Desenvolvimento Sustentável: Mito ou Realidade?". IN: Terra Livre, n. ${ }^{\circ}$ 11-12. São Paulo: AGB, 1992, p. 91-102.

RIBEIRO, W. C. Cidades ou sociedades sustentáveis? In: CARLOS, A. F. A.; CARRERAS, C. (Org.). Urbanização e mundialização: estudos sobre a metrópole. 1. ${ }^{a}$ ed. São Paulo: Contexto, v. 1, p. 60-69, 2004.

RIZZI, C.A. A questão da participação da comunidade do Distrito de Perus-(São Paulo/Brasil), no projeto MDL Aterro Bandeirantes. In: Revista Confins Franco Brasileira de Geografia, no 11, 2011a. Disponível em <http://confins.revues.org/6870>. Acessado em: 01 de abril de 2012 .

O uso dos fundos de consumo: A dinâmica da expansão metropolitana da Cidade de São Paulo. Dissertação de Mestrado (Mestrado em Geografia Humana) FFLCH-USP, São Paulo, 2011b.

RODRIGUES, A. M. Problemática Ambiental = Agenda Política Espaço, território, classes sociais. Boletim Paulista de Geografia - "Perspectiva Crítica" - nº 83, dezembro de 2005, p.91 a 110. São Paulo: Associação dos Geógrafos Brasileiros - AGB-SP.

ROLNIK, R. A cidade e a lei: legislação, política urbana e territórios na cidade de São Paulo. São Paulo: Studio Nobel/FAPESP, 1997.

Remoções forçadas em tempos de novo ciclo econômico. In: Revista Carta Maior. Disponível em: http://cartamaior.com.br/?/ Editoria/Politica/Remocoes-forcadasem-tempos-de-novo-ciclo-economico\% 0D\%0A/4/25808 Acessado em: agosto de 2012. 
ROLNIK, R. e SANTORO, P. "Novas frentes de expansão do complexo imobiliáriofinanceiro em São Paulo". In: Cad. Metrop., São Paulo, v. 19, n. 39, pp. 407-431, maio/ago 2017.

ROLNIK, R.; LEITÃO, K. ; COMARU, F. ; LINS, R.. (Org.). Observatório de Remoções 2015- 2017: Relatório final de projeto. São Paulo: Observatório das Remoções- FAU USP. 2017.

SAFRANSKY, S. "Greening the urban frontier: Race, property, and resettlement in Detroit". In: Geoforum, v.56, 2014, pp. 237-248.

SAlGADO E. C. O.; SAlGADO F. G. A.; J. POLICE NETO. Plano de bairro no limite do seu bairro uma experiência sem limites. 1ª ed. Cia. dos Livros, São Paulo, 2011. Plano de bairro Perus em transformação. $1^{\mathrm{a}}$ ed. Cia. dos Livros, São Paulo, 2012.

SANDEVILlE JR., E. ; ANGILELI, C.M.M. Quando a Casa Vira Parque. In: XV ENAMPUR, 2013, Recife. Anais do XV ENAMPUR, 2013. Disponível em < https://nep.arq.br/2018/03/08/1213/\#sdfootnote6anc > acessado em 02 de junho de 2018 .

SANTANA, P.V. A mercadoria verde: a natureza. In: DAMIANI, A.L.; CARLOS, A.F.A.; SEABRA, O.C.L. O espaço no fim de século: a nova raridade. São Paulo: Contexto, pp. $177-189,1999$.

SANTOS, C. J. F. Várzea do Carmo: Lavadeiras, Caipiras e 'Pretos Véios'. Memória Energia, São Paulo, v. 1, n.28, 2001. Disponível em < http://www.energiaesaneamento.org.br/media/28677/santos_carlos_jose_ferreira_varzea _do_carmo_lavadeiras_caipiras_e_pretos_veios.pdf > Acessado em 10 de outubro de 2017.

SÃO PAULO (Município), Secretaria da Habitação e Desenvolvimento Urbano/PMSP e Companhia de Processamento de Dados do Município de São Paulo (Prodam), Base Cartográfica Digital das Favelas do Município de São Paulo, 2000.

SÃO PAULO (Município), Secretaria Municipal de Habitação (Sehab). Banco de dados de favelas, núcleos urbanizados, loteamentos e cortiços. São Paulo: Sehab, 2009. Disponível em www.habisp.inf, Acessado em junho de 2009.

SÃO PAULO (Município), Secretaria Municipal de Habitação (Sehab). Complexo Bamburral - Relatório Analítico da Situação Cadastral. São Paulo, 2011. Relatório

SÃO PAULO (Município), Secretaria Municipal de Habitação (Sehab). Subprefeitura de Perus/Anhanguera. São Paulo: Secretaria de Habitação, 2013. 58 slides, colorido. 
SÃO PAULO (Município), Lei $n^{\circ} 16.050$ de 31 de julho de 2014. Aprova a política de desenvolvimento urbano e o plano diretor estratégico do município de São Paulo. São Paulo: 2014.

SÃO PAULO (Município), Extrato de termo de aditamento de contrato, de 07 de julho de 2016. Diário Oficial da cidade de São Paulo, SP, ano 61, n. 125, 07 jul. 2016, processo 2015-0.161.527-7.

SEABRA, O. C. L. Os meandros dos rios nos meandros do Poder. Tietê e Pinheiros: valorização dos rios e das várzeas na cidade de Paulo. Tese de doutoramento em geografia. São Paulo: FFLCH/USP, 1986.

Todos ao $10^{\circ}$ ENG - Recife. Editorial. In: $A G B$ em Debate, ano 7, $\mathrm{n}^{\circ} 10$, São Paulo, novembro de 1995.

. Urbanização e fragmentação cotidiano e vida de bairro na metamorfose da cidade em metrópole, a partir das transformações do Bairro do Limão Livre-docência em geografia. São Paulo: FFLCH/USP, 2003a.

. Os embates entre as questões ambientais e sociais no urbano. IN: CARLOS, A. F. A.; LEMOS, A. I. G. (Orgs.). Dilemas urbanos: novas abordagens sobre a cidade. São Paulo, Contexto, pp. 308-322, 2003 b.

. "São Paulo: a cidade, os bairros e a periferia". In: CARLOS, A. F.; OLIVEIRA, A. U. (Orgs.). Geografias de São Paulo: representação e crise da Metrópole. São Paulo, Contexto, pp. 271-311, 2010.

Higienismo e ambientalismo: filosofias do urbano. Relatório CNPq, Processo nº. 311112/2009-9 [S.I.]: 2013. Não publicado.

SERPA, Angelo. Parque público: Um "álibi verde" no centro de operações recentes de requalificação urbana?. Cidades: Revista Científica / Grupo de Estudos Urbanos - GEU, [S.1.], v. 2, n. 3, p. 111-141, jan. 2005.

SIQUEIRA, E. Companhia Brasileira de Cimento Portland Perus:contribuição para uma história da indústria pioneira do ramo no Brasil (1926-1987). Dissertação de mestrado, Universidade Estadual Paulista (UNESP), 2001.

SMITH, N. Desenvolvimento desigual: Natureza, Capital e a Produção do Espaço. Rio de Janeiro: Bertrand, 1988.

. Nature as Accumulation Strategy. Socialist Register, n. 43, p. 16-36, 2006.

- Gentrificação, a fronteira e a reestruturação do espaço urbano. IN: Revista Geousp - Espaço e Tempo, São Paulo, No 21, pp. 15 - 31, 2007. Disponível em http://citrus.uspnet.usp.br/geousp/ojs-2.2.4/index.php/geousp/article/view/268/140. 
Acessado em 05 de abr. de 2014.

SOUZA, M. L. O lugar das pessoas nas agendas "verde", "marrom" e "azul": Sobre a dimensão geopolítica da política ambiental urbana. 2014. Disponível em: http://passapalavra.info/2014/12/101245. Acessado em 08 de janeiro de 2015.

SCHWARZ, R. Ao Vencedor As Batatas, São Paulo: Duas Cidades, 1992, 4. a ed.

TRAVASSOS, L. Revelandos os rios. Novos paradigmas para a intervenção em fundos de vale urbanos na Cidade de São Paulo. Tese de Doutoramento, PROCAM-USP, São Paulo, 2010.

TOMÁS, E. O Tietê, o Higienismo e as Transformações na Cidade de São Paulo (1890-1930) Dissertação de Mestrado, Centro de Filosofia e Ciências Humanas da UFSC, Florianópolis, 1996.

TORRES, Maria Celestina Teixeira Mendes. O bairro do Brás. São Paulo: Secretaria Municipal de Cultura - DPH, 1969. 250 p. (Série História dos Bairros de São Paulo).

URBE PLANEJAMENTO URBANISMO E ARQUITETURA. Plano de Bairro do Distrito de Perus. Elaborado em 2008. Disponível em http://www.carlosneder.com.br/site/_FILES/arquivos_internos/04052012-142731candido_malta.pdf. Acessado em 08 de março de 2014.

VELLARDI, A.C.V. Uma narrativa histórica e geográfica de paisagem da porção noroeste da metrópole de São Paulo: uma contribuição à educação. Dissertação de Mestrado FAU-USP, São Paulo, 2017. 


\section{Anexo 1 - Descrição dos gastos dos recursos dos créditos de carbono da PMSP entre 2008 e 2011}

Prefeitura do Município de São Paulo

Secretaria Municipal do Verde e do Meio Ambiente

Conselho do Fundo Especial do Meio Ambiente e Desenvolvimento Sustentável

Fundo Especial do Meio Ambiente e Desenvolvimento Sustentável

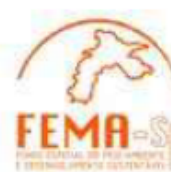

PROJETOS FINANCIADOS COM RECURSOS DE CRÉDITOS DE CARBONO

ANO 2008

FEMA - Crédito de Carbono

\begin{tabular}{|l|l|}
\hline \multicolumn{1}{|c|}{ Objeto } & \multicolumn{1}{|c|}{ Valor Pago } \\
\hline Plano de Bairro Destrito de Perus & $\mathrm{R} \$ 587.278,36$ \\
Contrato de Desfazimento Sub de Pirituba & $\mathrm{R} \$ 706.665,84$ \\
Praça Jardim Monte Belo & $\mathrm{R} \$ 509.750,76$ \\
Praça Mogoeiro & $\mathrm{R} \$ 411.435,90$ \\
Praça Jardim Cuitegi & $\mathrm{R} \$ 172.277,01$ \\
CRAS Anhanguera & $\mathrm{R} \$ 13.358,46$ \\
Praça Tarcon & $\mathrm{R} \$ 23.059,70$ \\
Praça Canhoba & $\mathrm{R} \$ 36.724,48$ \\
Projeto para equipamento público esportivo Sub de Perus & $\mathrm{R} \$ 28.779,79$ \\
Projeto para 9 praças Sub de Perus & $\mathrm{R} \$ 139.710,79$ \\
Desapropriação para o Parque Linear Ribeirão Perus & $\mathrm{R} \$ 115.753,61$ \\
Desapropriação para o Parque Linear Ribeirão Perus & $\mathrm{R} \$ 1.867 .326,35$ \\
Desapropriação para o Parque Linear Ribeirão Perus & $\mathrm{R} \$$ 6.755.606,68 \\
Desapropriação para o Parque Linear Ribeirão Perus & $\mathrm{R} \$ 388.463,98$ \\
\hline Total Pago /2008 & $\mathrm{R} \$ 11.756 .191,71$ \\
\hline
\end{tabular}

ANO 2009

FEMA - Crédito de Carbono

\begin{tabular}{|l|l|}
\hline \multicolumn{1}{|c|}{ Objeto } & \multicolumn{1}{|c|}{ Valor Pago } \\
\hline Aquisição de livros - Projeto Zeladores de Praças & $\mathrm{R} \$ 6.381,20$ \\
Aquisição de uniformes - Projeto Zeladores de Praças & $\mathrm{R} \$ 27.878,10$ \\
Aquisição de EPIs - Projeto Zeladores de Praças & $\mathrm{R} \$ 16.504,06$ \\
Aquisição de Ferramentas - Projeto Zeladores de Praças & $\mathrm{R} \$ 13.944,18$ \\
Palest. Renata Iride Longo da Costa - Projeto Zeladores de Praças & $\mathrm{R} \$ 7.200,00$ \\
Palestrante Marco Aurélio Gattamorta - Projeto Zeladores de Praças & $\mathrm{R} \$ 4.800,00$ \\
Palest. José Luiz Domingues - Projeto Zeladores de Praças & $\mathrm{R} \$ 6.000,00$ \\
Contrato de Desfazimento Sub de Pirituba & $\mathrm{R} \$ 564.746,00$ \\
Praças (Tarcon, José Correia Picanço, Canhoba, Mogeiro, Cuitegi, & \\
Monte Belo, Flor de Imperatriz, Vale do Saber) & $\mathrm{R} \$ 614.794,70$ \\
Parque Senhor do Vale & $\mathrm{R} \$ 644.031,51$ \\
CRAS Anhanguera & $\mathrm{R} \$ 2.341 .060,43$ \\
Desapropriação para o Parque Linear Ribeirão Perus & $\mathrm{R} \$ 941.257,11$ \\
Desapropriação para o Parque Linear Ribeirão Perus & $\mathrm{R} \$ 23.305,68$ \\
Desapropriação para o Parque Linear Ribeirão Perus & $\mathrm{R} \$ 408.972,74$ \\
\hline Total Pago /2009 & $\mathrm{R} \$ 5.620 .875,71$ \\
\hline
\end{tabular}


Prefeitura do Município de São Paulo Secretaria Municipal do Verde e do Meio Ambiente Conselho do Fundo Especial do Meio Ambiente e Desenvolvimento Sustentável Fundo Especial do Meio Ambiente e Desenvolvimento Sustentável

ANO 2010

FEMA - Crédito de Carbono

\begin{tabular}{|l|l|}
\hline \multicolumn{1}{|c|}{ Objeto } & \multicolumn{1}{|c|}{ Valor Pago } \\
\hline Parque Senhor do Vale e Projeto do Parque Linear Ribeirão Perus & $\mathrm{R} \$ 1.075 .612,50$ \\
Desapropriação para o Parque Linear Ribeirão Perus & $\mathrm{R} \$ 2.128 .288,54$ \\
Desapropriação para o Parque Linear Ribeirão Perus & $\mathrm{R} \$ 221.133,50$ \\
Desapropriação para o Parque Linear Ribeirão Perus & $\mathrm{R} \$ 6.085 .857,50$ \\
Desapropriação para o Parque Linear Ribeirão Perus & $\mathrm{R} \$ 265.243,72$ \\
Desapropriações Parque Anhanguera & $\mathrm{R} \$ 1.419 .110,00$ \\
Desapropriações Parque Anhanguera & $\mathrm{R} \$ 1.696 .393,73$ \\
Desapropriações Parque Anhanguera & $\mathrm{R} \$ 1.495 .882,65$ \\
Desapropriações Parque Anhanguera & $\mathrm{R} \$ 1.419 .110,00$ \\
Desapropriações Parque Anhanguera & $\mathrm{R} \$ 6.636 .400,35$ \\
Desapropriações Parque Anhanguera & $\mathrm{R} \$ 3.639 .307,60$ \\
Desapropriações Parque Anhanguera & $\mathrm{R} \$ 1.717 .123,10$ \\
Desapropriações Parque Anhanguera & $\mathrm{R} \$ 2.364 .353,40$ \\
Desapropriação em área de risco - Travessa José de Oliveira & $\mathrm{R} \$$ \\
CRAS Anhanguera, Praças, UTI II e Escola de Marcenaria & $10.324,38$ \\
\hline Total Pago /2010 & $\mathrm{R} \$ 2.270 .188,15$ \\
\hline
\end{tabular}

ANO 2011

FEMA - Crédito de Carbono

\begin{tabular}{|l|c|}
\hline \multicolumn{1}{|c|}{ Objeto } & \multicolumn{1}{|c|}{ Valor Pago } \\
\hline Praça Senhor do Vale e projeto Pq. Linear Ribeirão Perus & $\mathrm{R} \$ 488.304,00$ \\
\hline CRAS Anhanguera. Escolade Marcenaria, Ecoponto & $\mathrm{R} \$ 2.067 .788,83$ \\
\hline Total Pago /2011 & $\mathrm{R} \$ 2.556 .092,83$ \\
\hline
\end{tabular}

TOTAL GERAL DE RECURSOS APLICADOS - CRÉDITO DE CARBONO - R\$ 52.377.489,37

São Paulo, 05 de março de 2012. 